\title{
APLICAÇÃO DE REATORES ANAERÓBIOS PARA REMOÇÃO DE SULFATO DE ÁGUAS DE DRENAGEM ÁCIDA DE MINAS
}

\author{
Tese apresentada à Escola de \\ Engenharia de São Carlos, da \\ Universidade de São Paulo, como parte \\ dos requisitos para a obtenção do título \\ de Doutora em Ciências (Programa de \\ Engenharia Hidráulica e Saneamento)
}

ORIENTADOR: PROF. MARCELO ZAIAT

São Carlos, SP 
AUTORIZO A REPRODUÇÃO E DIVULGAÇÃO TOTAL OU PARCIAL DESTE TRABALHO, POR QUALQUER MEIO CONVENCIONAL OU ELETRÔNICO, PARA FINS DE ESTUDO E PESQUISA, DESDE QUE CITADA A FONTE. da Informação do Serviço de Biblioteca - EESC/USP

Rodriguez, Renata Piacentini

Aplicação de reatores anaeróbios para remoção de

sulfato de águas de drenagem ácida de minas / Renata

Piacentini Rodriguez ; orientador Marcelo Zaiat. -- São

Carlos, 2010 .

Tese (Doutorado-Programa de Pós-Graduação em Engenharia Hidráulica e Saneamento) -- Escola de Engenharia de São Carlos da Universidade de São Paulo, 2010 .

1. Drenagem em minas. 2. Sulfato. 3. RAHLF. 4. Reator UASB. 5. Relação $\mathrm{COD} / \mathrm{SO}_{4}{ }^{2-}$. 6. Carga de sulfato aplicada. 7. Recirculação. I. Título. 


\section{FOLHA DE JULGAMENTO}

Candidato(a): Farmacêutico Bioquímico RENATA PIACENTINI RODRIGUEZ

Tese defendida e julgada em 30/04/2010 perante a Comissão Julgadora:

Prof. Associado MARCELO ZAIAT - (Orientador)

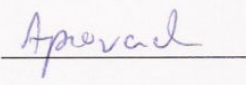

(Escola de Engenharia de São Carlos/USP)

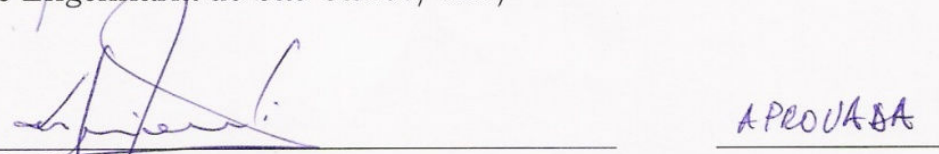

Prof. Titular EUGENIO FORESTI

(Escola de Engenharia de São Carlos/USP)

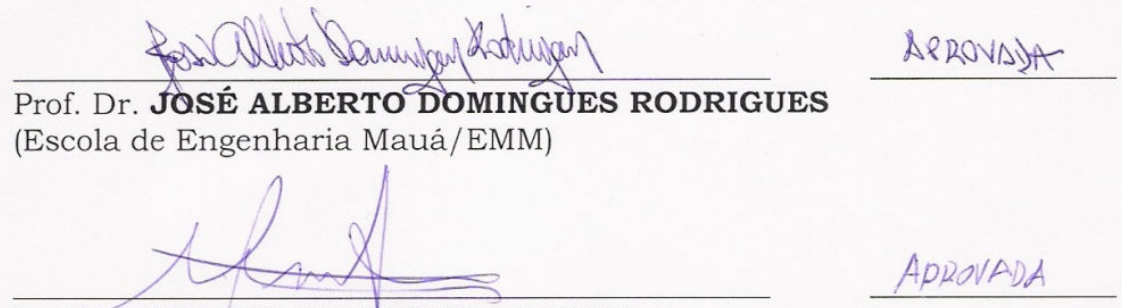

Prof.-Dr. MARCELO LOUREIRO GARCIA

(Universidade Estadual Paulista "Julio de Mesquita Filho"/UNESP-Campus de Rio Claro)
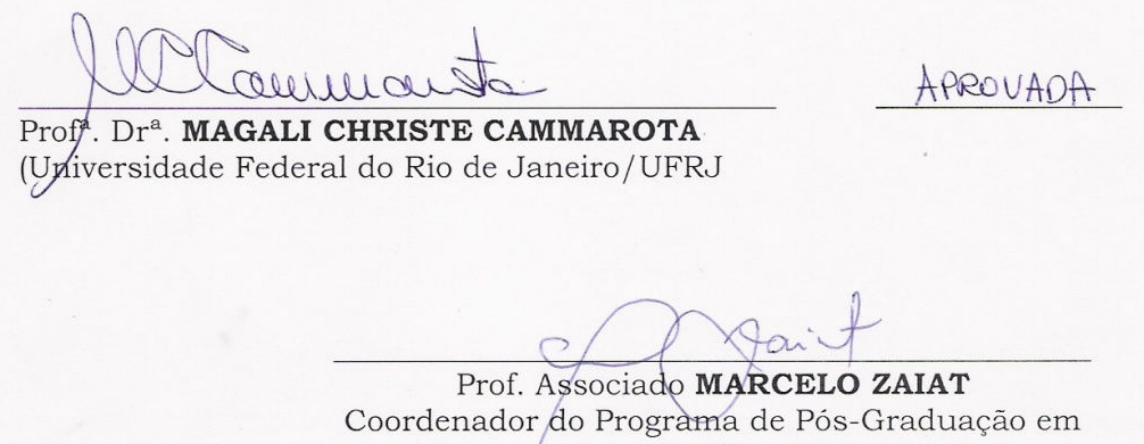

Engenharia Hidráulica e Saneamento

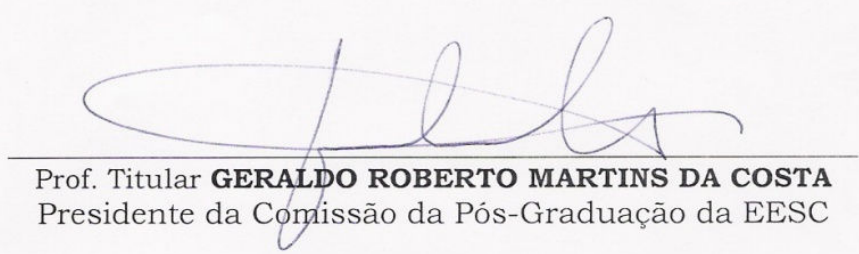



DEDICATÓRIA

A quem me ensinau a que significam as palauras forsa, coragem e wontade de wencer:

minha Mẫe. 
À Deus, por me oferecer meu presente maior, a vida.

Aos meus pais, Alvaro e Gema, por acreditarem em mim desde o primeiro dia que souberam da minha existência e por me ensinarem que para ser grande é preciso se sentir grande.

À minha irmãzinha caçula querida, Patricia, por ser a minha eterna companheira nas aventuras dessa vida.

Ao João, pelo amor incondicional e por me fazer a pessoa mais feliz do mundo. É por nós dois que dediquei essas horas e horas de empenho. Te amo querido.

Aos meus avós, Guido e Edna, Basílio e Maria, responsáveis pela existência da minha família e por todo o amor que me rodeia.

Ao Professor Marcelo Zaiat, ou Zaiat como eu o chamo, que foi além de um orientador. Foi um profissional inspirador, conselheiro e amigo em todas as horas, tenham sido fáceis ou difíceis. Obrigada por me ajudar a ser uma profissional mais madura e preparada.

Ao Professor Eugênio Foresti, um mestre na área profissional e um ser humano incomparável.

Aos meus amigos mais que queridos... Dani, obrigada por ser minha companheira para tudo! Você é uma pessoa incrível e juntas vivemos e viveremos momentos inesquecíveis. Bruna e Ana, vocês foram as melhores "roommattes" que eu poderia desejar, além de serem 
amigas que terei para sempre junto de mim. Theo, você é um amigo e tanto. Inspirador na arte de conduzir seu trabalho. Jú, você é a nossa menininha e tem lugar reservado. Rafa, obrigada pela amizade, papos e ensinamentos.

Aos meus alunos de iniciação, Guilherme e Isabela, que foram peças-chave na realização desse trabalho. Além da minha aluna adotada, Rachel, que é minha amiga querida.

Aos amigos e colegas de laboratório, Thiagão, Anne, Neto, Isabel, Regiane, Sandra, Lorena, Gustavo, Jorge, Guilherme, Márcia, Betão, Marcelinho e Carol.

Às funcionárias do Laboratório de Processos Biológicos, Janja e Eloísa, pela constante disposição em me auxiliar quando precisei durante a fase experimental desta pesquisa.

Às secretárias do curso de pós-graduação em Hidráulica e Saneamento, Rose, Sá e Pavi, pelas informações e por todo auxílio.

À Indústria Nucleares do Brasil, em nome do Sr. Ivan Antunes, por disponibilizar o acesso e a coleta do material deste trabalho, além das informações fornecidas sobre a mina Osamu Utsumi.

Ao CNPq por parte da bolsa de doutorado concedida.

À FAPESP pela bolsa e pelo auxílio financeiro concedidos.

A todos aqueles que contribuíram, direta ou indiretamente, para a realização deste trabalho. 


\section{TIME TO SAY GOODBYE...}

Na ultima sexta foi o día da minha mudança de São Carlos. Depoís de recolher minhas coisas durante duas semanas e com uma casa atolada de caixas de papelão, tive que dizer adeus a minha casinha...

São Carlos definitivamente não será apenas uma cidade que encontrei pelo caminho. Nessas ruas, restaurantes, lojas, universidade e tudo que me rodeou vivi uma história. Foram cerca de 3 anos com descidas, subidas, altos e baixos. Mas foram tempos de rir, se divertir, fazer amigos e amadurecer. Foi tempo de estudar, ensinar, aprender e me "doutorar".

Daqui levarei lembranças sem fím.

Foi aqui que encontrei a minha carreira profissional e descobri porque eu gostava de estudar tanto... Aprendi o que era reator, escoamento hidrodinâmico, cinética e tudo de processos anaeróbios. Anotei todas para ensinar ao meu filhinho quando ele começar a tentar as primeiras palavras... Descobri que a carreira acadêmica estava muito além do que eu imaginava ser e me apaixonei sem perceber.

Nessa cidade chorei as maiores dores que vivi até então. Me senti sozinha, sem rumo, sem amigos e sem destino. Mas, sempre encontrava alguém que enxugava as minhas lágrimas.

Entre novas descobertas, descobri meus amigos queridos... Eles sabem quem são e como têm um lugar reservado no meu coração. Com eles, vivi grandes risadas, bagunças, conversas sérías e bobas, comilanças sem fim, cantorias, danças, churrascos, enfim... grande parte do que melhor eu vivi nesses anos.

Tem a que me acolheu quando mais precisei... Tem a minha grande companheira de baladas e altos papos sobre a vida... A minha companheira de apê que entende tudo de futebol... Aquela que sempre otha pra mim com um rostinho meigo e todo carinhoso... Aquele que sabe muito sobre tudo e é uma ótima companhia pra bater papo... Tem meu amigo que mora longe agora e que é um dos caras mais românticos que conheço... Tem aquele que vive sonhando com a Europa e sabe tudo sobre as marcas chiques... $\mathcal{A}$ vocês eu agradecerei eternamente e deixo um beijo especial na bochecha de cada um.

Nessa cidade também descobri como é fantástico ter um chefe que te inspira, te escuta e sempre tem um consetho certo na hora certa. Além de conhecer tudo da 
cídade e ter sido minha grande fonte de informação nesta nova terra, ele também me ensinou a valorizar nossa profissão e abriu meus horizontes acadêmicos.

Aqui também conheci grandes fíguras, muito engraçadas e que também não serão esquecidas. NNem que seja pra uma boa risada...

Aprendi como é bom ser independente, ser responsável pelas suas contas, saber colocar um prego na parede e levar o carro no mecânico. Essa sensação depoís de vivenciada não me deixará nunca mais... podem acreditar que é bom mesmo!

Em Sanca, como chamamos carinhosamente, conheci uma pessoinha muito especial que ocupa um fugar reservado no meu coração e que não será apenas uma lembrança dessa cídade para mim, pois o meu amor não sai mais do meu lado a partir de agora.

São Carlos foi tudo. De zero a dez. O feliz e o triste. O ensolarado e o chuvoso. $\mathcal{A}$ companhía e o solitário. $\mathcal{E}$ o amor... mais do que tudo!

Obrigada por me receber tão bem e me proporcionar anos incriveis! Tchau...

Renata.

(texto escrito após a minha mudança de São Carlos, em janeiro de 2010). 


\section{RESUMO}

O presente trabalho teve, por objetivo principal, analisar a remoção de sulfato em águas de drenagem ácida de minas em dois tipos de reatores anaeróbios, um com crescimento granular (UASB) e outro com biomassa aderida (RAHLF). Estudos anteriores publicados na literatura apresentam resultados positivos quanto ao tratamento anaeróbio de drenagem ácida de minas, entretanto, na maioria deles, é aplicado um tratamento preliminar à água residuária antes do tratamento principal. Esse trabalho avaliou a operação de reatores anaeróbios sem prévio tratamento da drenagem ácida sob diferentes variáveis. Para o reator anaeróbio horizontal de leito fixo (RAHLF), foram analisadas as variáveis relação $\mathrm{DQO} / \mathrm{SO}_{4}{ }^{2-}$, correção do pH afluente, carga de sulfato aplicada e a recirculação da fase líquida. Os resultados mostraram que a redução da carga de sulfato aplicada foi o fator determinante para os bons resultados de remoção, encontrados ao longo da operação dos reatores $(70 \%$ de remoção de sulfato e $75 \%$ de remoção de DQO). A relação $\mathrm{DQO} / \mathrm{SO}_{4}{ }^{2-}$ também foi importante e quando utilizada a relação estequiométrica de 0,67 , a eficiência de remoção de sulfato atingiu níveis superiores a 70\% com pequeno acúmulo de ácido acético no efluente. Para a operação do reator anaeróbio de manta de lodo (UASB), as variáveis analisadas foram o volume da manta de lodo, a relação $\mathrm{DQO} / \mathrm{SO}_{4}{ }^{2-}$, a carga de sulfato aplicada e a recirculação da fase líquida. Como para o RAHLF, a redução da carga de sulfato aplicada foi essencial para o melhor funcionamento do UASB. A relação $\mathrm{DQO} / \mathrm{SO}_{4}{ }^{2-}$ de 1,0 promoveu melhora na eficiência do reator, quando comparada à relação estequiométrica e a recirculação no reator só foi positiva quando realizada com água de abastecimento, tendo o reator entrado em colapso quando a recirculação foi realizada com o efluente tratado.

Palavras-chave: drenagem ácida de minas, sulfato, RAHLF, reator UASB, relação $\mathrm{DQO} / \mathrm{SO}_{4}{ }^{2-}$, carga de sulfato aplicada, recirculação. 


\begin{abstract}
The main objective of this work was to evaluate the sulfate removal from acid mine drainage in two types of anaerobic reactors, one with a granular sludge (UASB) and another with immobilized biomass (HAIB reactor). Previous published studies have showed positive results for the anaerobic treatment of acid mine drainage, however, in most of them, it was applied a pre-treatment operation. This study evaluated the operation of anaerobic reactors without pre-treatment of the acid mine drainage under different parameters. The parameters $\mathrm{COD} / \mathrm{SO}_{4}{ }^{2-}$ ratio, correction of affluent $\mathrm{pH}$, sulfate loading and recirculation of the liquid phase were tested for horizontal-flow anaerobic immobilized biomass (HAIB) reactor. The results showed that the decrease in the sulfate loading was a determining factor for the successful sulfate removal found throughout the operation of the reactors. The $\mathrm{COD} / \mathrm{SO}_{4}{ }^{2-}$ ratio was also important and the removal efficiency of sulfate reached levels above $70 \%$ with a small accumulation of acetic acid in the effluent when using stoichiometric ratio of 0.67 . For the operation of the upflow anaerobic sludge blanket (UASB) reactor, the parameters were the volume of the sludge blanket, the $\mathrm{COD} / \mathrm{SO}_{4}{ }^{2-}$ ratio, the sulfate loading and the recirculation of the liquid phase. Similarly ti the HAIB reactor, reducing the sulfate load was essential for obtaining better results. The $\mathrm{COD} / \mathrm{SO}_{4}{ }^{2-}$ ratio of 1.0 showed a improved sulfate removal efficiency for the UASB reactor when compared to stoichiometric ratio at 0.67 and the recirculation in this reactor was only positive when carried out with tap water. The UASB reactor collapsed when recirculation was carried out with the treated effluent.
\end{abstract}

Keywords: acid mine drainage, sulfate, HAIB reactor, UASB reactor, $\mathrm{COD} / \mathrm{SO}_{4}{ }^{2-}$ ratio, sulfate load, recirculation. 


\section{LISTA DE FIGURAS}

Figura 3.1. Vista geral da cava da mina Osamu Utsumi. 10

Figura 3.2.Visão geral das unidades desativadas do processamento de minério na mina Osamu Utsumi. (A) Mineroduto que conduzia o minério da extração até as unidades físicas de redução de tamanho do minério. (B) Tambor onde ocorria a operação de moagem do minério.

Figura 3.3.Visão geral da unidade de tratamento de DAM da mina Osumi Utsumi. (A) Tanques do preparo da cal e de mistura (à direita, com cobertura) e do tanque de sedimentação (à esquerda). (B) Visão superior do tanque de sedimentação, onde há formação e separação do precipitado de sulfato de cálcio e metais. 11

Figura 3.4. Ciclo do Enxofre (Lens e Kuenen, 2001)..... 12

Figura 3.5. Etapas da conversão de sulfato a APS e redução a HS ${ }^{-}$(Hansen, 1994). .............. 15

Figura 3.6. Etapas de degradação da matéria orgânica na presença de sulfato (Muyzer e Stams, 2008).

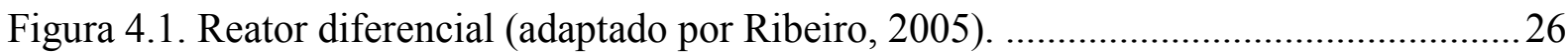

Figura 4.2. Esquema das instalações experimentais do RAHLF........................................... 31

Figura 4.3. Foto dos reatores anaeróbios horizontais de leito fixo (RAHLF) em operação, instalados na câmara para controle de temperatura............................................ 31

Figura 4.4. Esquema do reator UASB com as principais medidas $(\mathrm{em} \mathrm{cm})$. ........................... 32

Figura 4.5. Foto do reator UASB instalado em câmara de controle de temperatura.................33

Figura 5.1. Crescimento da biomassa em sólidos totais voláteis (g) por massa (g) de material suporte ( $\boldsymbol{\nabla}$ : ácido fórmico e AI; $\diamond$ : ácido fórmico e SI; $\mathbf{\square}$ : etanol e AI, $\boldsymbol{\Delta}$ : etanol e SI, ○: ácido lático e $\mathrm{AI}$; +: ácido lático e $\mathrm{SI}$ ). AI: inóculo anaeróbio de abatedouro e SI: inóculo do sedimento de mina. 46

Figura 5.2. Velocidades de colonização em função do tempo no material suporte ( $\boldsymbol{\nabla}$ : ácido fórmico e AI; $\diamond$ : ácido fórmico e SI; $\mathbf{m}$ : etanol e AI, $\boldsymbol{\Delta}$ : etanol e SI, o: ácido lático e $\mathrm{AI} ;+$ : ácido lático e SI). AI: inóculo anaeróbio de abatedouro e SI: inóculo de sedimento de mina.

Figura 5.3. Curva F (a) e curva E (b) obtidas em ensaio do tipo degrau para TDH teórico de 24 horas.

Figura 5.4. Curva F (a) e curva E (b) obtidas em ensaio do tipo degrau para TDH teórico de 24 horas.

Figura 5.5. Variação do $\mathrm{pH}$ afluente ( $\bullet$ e efluente (घ) no RAHLF 1. 65

Figura 5.6. Variação da DQO afluente $(\diamond)$, efluente $(\boldsymbol{\bullet})$ e eficiência de remoção $(\boldsymbol{\Delta})$ no RAHLF 1.

Figura 5.7. Variação da concentração de ácido acético (efluente - afluente) no RAHLF 1...667

Figura 5.8. Variação da concentração de sulfato afluente ( $\bullet$, efluente (ロ) e eficiência de remoção $(\boldsymbol{\Delta})$ no RAHLF 1.

Figura 5.9. Imagem de bactéria como morfologia semelhante a bactérias fermentativas encontrada no leito do RALHF 1................................................................ 72

Figura 5.10. Variação da concentração de sulfeto efluente (घ) no RAHLF 1......................... 73

Figura 5.11. Variação da pH afluente ( $\bullet$ e efluente (घ) no RAHLF 2. .................................. 74 
Figura 5.12. Variação da DQO afluente $(\diamond)$, efluente $(\boldsymbol{\bullet})$ e eficiência de remoção $(\boldsymbol{\Delta})$ no RAHLF 2.

Figura 5.13. Variação da concentração de ácido acético (efluente - afluente) no RAHLF 2. . 77

Figura 5.14. Variação da concentração de sulfato afluente ( $\bullet$ ), efluente (ם) e eficiência de

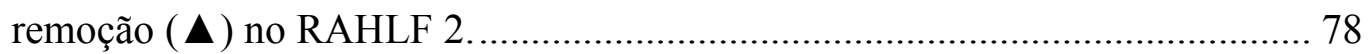

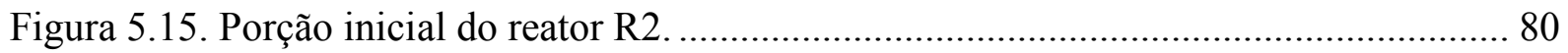

Figura 5.21. Variação da concentração de sulfeto efluente (घ) no RAHLF 2 ........................ 80

Figura 5.17. Variação do pH afluente $(\diamond)$ e efluente $(\mathbf{\bullet})$ no RAHLF 3 ................................... 81

Figura 5.18. Variação da concentração de DQO afluente ( $\bullet$, efluente $(\mathbf{\square})$ e eficiência de

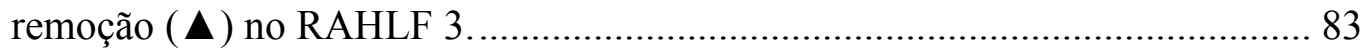

Figura 5.19. Variação na concentração de ácido acético (efluente - afluente) no reator R3 .. 85

Figura 5.20. Variação da concentração de sulfato afluente ( $\downarrow)$, efluente $(\boldsymbol{\square})$ e eficiência de remoção $(\boldsymbol{\Delta})$ no RAHLF 3 ............................................................................ 86

Figura 5.21. Imagem de microscopia de contraste de fase do reator R3. Bactérias com morfologia semelhante a bactérias fermentativas........................................... 88

Figura 5.22. Variação da concentração de sulfeto efluente (ם) no RAHLF 3 ....................... 89

Figura 5.23. pH recomendado para a precipitação de metais como sulfetos ou hidróxidos.... 91

Figura 5.24. Variação da concentração de DQO, sulfato e sulfeto ao longo do leito do R1 na

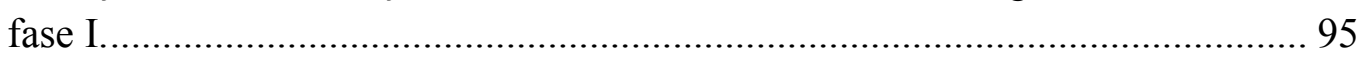

Figura 5.25. Variação da concentração de etanol e ácido acético no reator R1 na fase I........ 96

Figura 5.26. Comportamento do pH ao longo do leito do R2 na fase I. ................................. 97

Figura 5.27. Variação da concentração de DQO, sulfato e sulfeto ao longo do reator R2 na

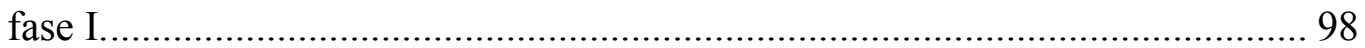

Figura 5.28. Variação da concentração de etanol e de ácido acético ao longo do reator R2 na

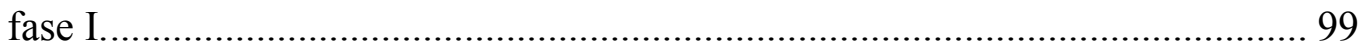

Figura 5.29. Variação do pH ao longo do leito do reator R2 na fase II. ................................. 99

Figura 5.30. Variação nas concentrações de DQO, sulfato e sulfeto ao longo do reator R2 na fase II.

Figura 5.31. Variação das concentrações de etanol e ácido acético ao longo do reator R2 na fase II.

Figura 5.32. Variação do pH ao longo do reator R3 na fase I. ............................................. 102

Figura 5.33. Variação nas concentrações de DQO, sulfato e sulfeto ao longo do reator R3 na fase I.

Figura 5.34. Variação das concentrações de etanol e ácido acético ao longo do reator R3 na fase I.

Figura 5.35. Variação do pH ao longo do reator R3 na fase II. ........................................... 104

Figura 5.36. Variação nas concentrações de DQO, sulfato e sulfeto ao longo do reator R3 na fase II.

Figura 5.37. Variação das concentrações de etanol e ácido acético ao longo do reator R3 na fase II.

Figura 5.38. Distribuição dos clones do reator R1 para o Dominio Archaea. ........................ 106

Figura 5.39. Distribuição dos clones do reator R2 para o Dominio Archaea. ....................... 107

Figura 5.40. PCR de Archaea para o reator R3 (I: amostra, II: controles positivos, III: branco). 
Figura 5.41. Distribuição dos clones do reator R1 para o Dominio Bacteria. 110

Figura 5.42. Distribuição dos clones do reator R2 para o Dominio Bacteria.......................... 111

Figura 5.43. Distribuição dos clones do reator R3 para o Dominio Bacteria......................... 112

Figura 5.44. Arvore filogenética dos reatores R1, R2 e R3 (não classificados: clones não classificados em nenhum filo do domínio correspondente)............................ 115

Figura 5.45. Acúmulo de $\mathrm{S}^{0}$ no leito do reator R1 ........................................................... 129

Figura 5.46. Comportamento do $\mathrm{pH}$ efluente para os reatores U1, U2 e U3. ........................ 135

Figura 5.47. Eficiências de remoção de DQO para os reatores U1, U2 e U3. ....................... 136

Figura 5.48. Eficiências de remoção de sulfato para os reatores U1, U2 e U3. ...................... 137

Figura 5.49. Concentrações de sulfeto efluente nos reatores U1, U2 e U3............................ 138

Figura 5.50. Variação do $\mathrm{pH}$ afluente e efluente no UASB, na etapa 2 de operação.............. 140

Figura 5.51. Variação da DQO afluente, efluente e da eficiência de remoção no UASB...... 142

Figura 5.52. Concentrações de ácido acético (efluente - afluente) no UASB, na etapa B de

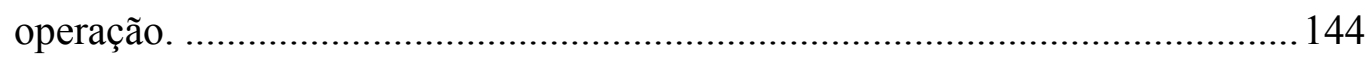

Figura 5.53. Variação da concentração de sulfato afluente, efluente e da eficiência de remoção no UASB, na segunda etapa de operação...................................................... 145

Figura 5.54. Variação da concentração de sulfeto afluente e efluente no UASB, na etapa 2 de

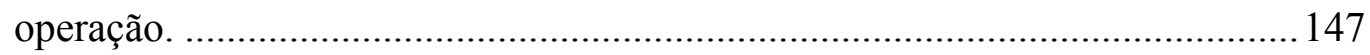

Figura 5.55. Variação do pH ao longo do reator UASB (etapa B - fase II)........................... 149

Figura 5.56. Variação da DQO, sulfato e sulfeto ao longo do reator UASB (etapa B - fase II).

Figura 5.57. Formação de película amarelada no interior do reator UASB, durante a segunda fase de operação.

Figura 5.58. Variação na concentração de etanol e ácido acético ao longo do reator UASB

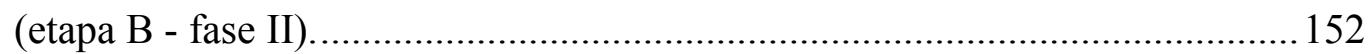

Figura 5.59. Variação do $\mathrm{pH}$ ao longo do reator UASB (etapa B - fase IV). ........................ 153

Figura 5.60. Variação da DQO, sulfato e sulfeto ao longo do reator UASB (etapa B - fase IV). 154

Figura 5.61. Estratificação do leito do reator UASB (etapa B).......................................... 155

Figura 5.62. Grânulos do leito do reator UASB (etapa B): a) porção inicial do reator; b)

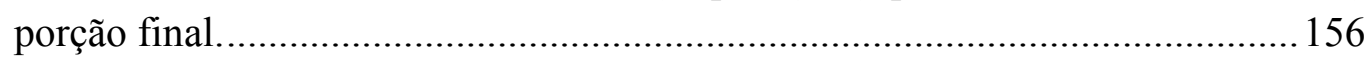




\section{LISTA DE TABELAS}

Tabela 3.1. Caracterização físico-química da drenagem ácida da mina Osamu Utsumi...... 9

Tabela 3.2. Variação de energia livre para as principais rotas de degradação anaeróbia da matéria orgânica (fonte: Muyzer e Stams, 2008).

Tabela 4.1. Fases realizadas durante a operação dos reatores anaeróbios horizontais de leito fixo (RAHLF).

Tabela 4.2. Etapas realizadas durante a operação do reator UASB.

Tabela 4.3. Parâmetros de monitoramento e frequência das análises.

Tabela 4.4. Primers empregados nas reações de PCR.

Tabela 5.1. Concentrações máximas de STV para cada condição analisada.

Tabela 5.2. Coeficientes de difusão em água dos substratos analisados.

Tabela 5.3. Velocidades máximas $\left(\mathrm{v}_{\max }\right)$ e médias $\left(\mathrm{v}_{\mathrm{med}}\right)$ de colonização para cada condição empregada (AI: inóculo de abatedouro, SI: inóculo do sedimento de mina). .......53

Tabela 5.4. Ajuste dos modelos de $\mathrm{N}$ reatores em série e de dispersão longitudinal............... 61

Tabela 5.5. Concentração de metais no afluente dos reatores R1, R2 e R3. ...........................63

Tabela 5.6. Resultados das análises de monitoramento para os reatores R1, R2 e R3............992

Tabela 5.7. Comparação de identidade para as UTOs de Archaea dos reatores R1 e R2 ( $P b$ : pares de bases).

Tabela 5.8 (continua). Comparação de identidade para as UTOs de Bacteria dos reatores R1, R2 e R3 (Pb: pares de bases).

Tabela 5.9. Dados de eficiência de remoção de DQO e sulfato e concentrações médias de ácido acético na operação dos reatores R1, R2 e R3.

Tabela 5.10. Concentração de metais no afluente do reator UASB. ...................................... 140

Tabela 5.11. Resultados das análises de monitoramento para o reator UASB na etapa B.... 148

Tabela 5.12. Dados de eficiência de remoção de DQO e sulfato e acúmulo de ácido acético na etapa B de operação do reator UASB. 


\section{ABREVIATURAS E SIGLAS}

\begin{tabular}{|c|c|}
\hline $16 S r R N A$ & unidade $16 \mathrm{~S}$ do RNA ribossomal \\
\hline$A T P$ & adenosina trifosfato \\
\hline$B R S$ & bactérias redutoras de sulfato \\
\hline$C / N$ & relação carbono e nitrogênio \\
\hline$D A M$ & drenagem ácida de mina \\
\hline$D N A$ & ácido desoxirribonucléico \\
\hline$D Q O$ & demanda química de oxigênio \\
\hline DTR & distribuição de tempo de residência \\
\hline $\mathrm{HCO}_{3}^{-}$ & íon bicarbonato \\
\hline $\mathrm{H}_{2} \mathrm{~S}$ & sulfeto de hidrogênio \\
\hline$H S$ & sulfeto na forma iônica \\
\hline$N A D H$ & nicotinamida adenina dinucleotídeo \\
\hline$P C R$ & reação da polimerase em cadeia \\
\hline$R A H L F$ & reator anaeróbio horizontal de leito fixo \\
\hline$R 1, R 2, R 3$ & RAHLF 1 , RAHLF 2 e RAHLF 3 \\
\hline$S^{0}$ & enxofre elementar \\
\hline $\mathrm{SO}_{4}^{2-}$ & íon sulfato \\
\hline$S T V$ & sólidos totais voláteis \\
\hline$T D H$ & tempo de detenção hidráulica \\
\hline$U A S B$ & upflow anaerobic sludge blanket \\
\hline$U 1, U 2, U 3$ & UASB1, UASB 2 e UASB 3 \\
\hline$v_{\text {máx }}$ & velocidade máxima \\
\hline$v_{m e ́ c}$ & velocidade média \\
\hline
\end{tabular}




\section{SUMÁRIO}

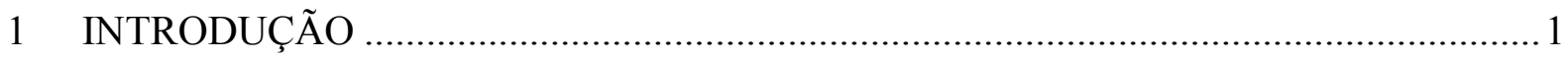

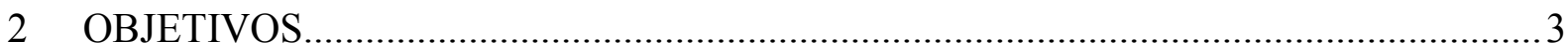

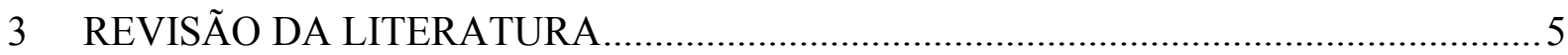

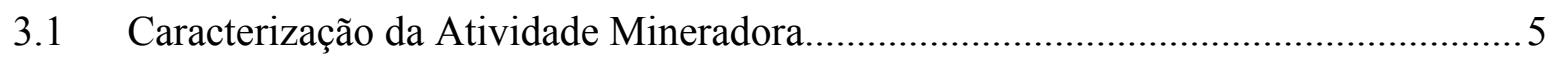

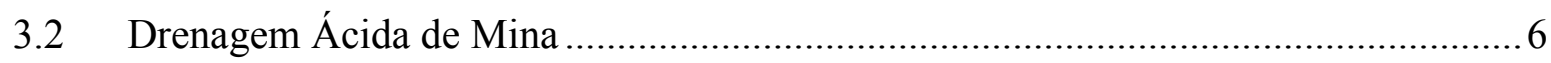

3.3 Mina Osamu Utsumi ...................................................................................

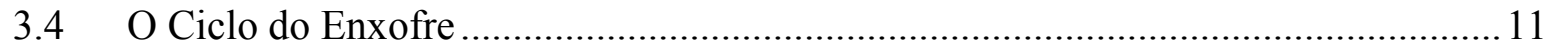

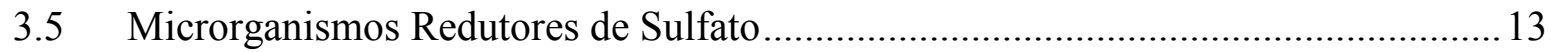

3.5.1 Metabolismo das bactérias redutoras de sulfato ................................................... 14

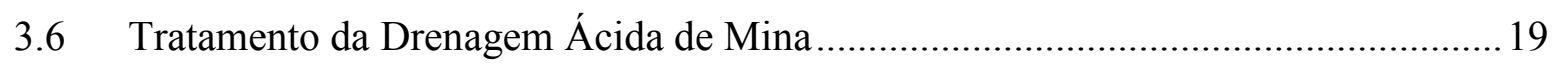

3.6.1 Tratamentos físico-químicos .......................................................................... 19

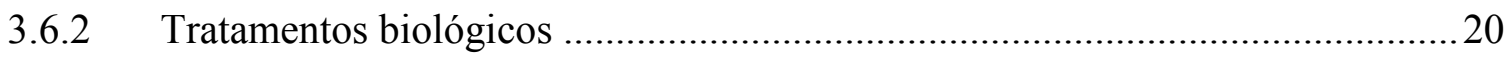

3.7 Considerações Finais ………………………………………………………....2

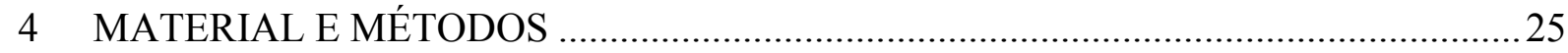

4.1 Ensaios de Imobilização da Biomassa em Espuma de Poliuretano .............................25

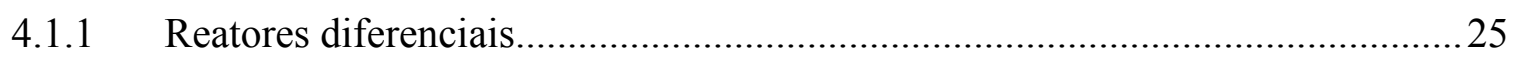

4.1.2 Suporte para imobilização da biomassa …………………………………….......2

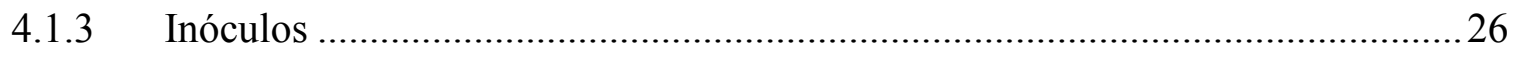

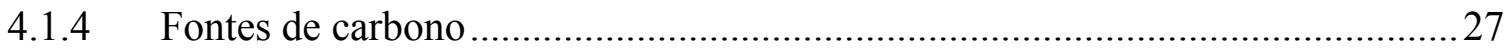

4.1.5 Protocolo experimental..........................................................................2

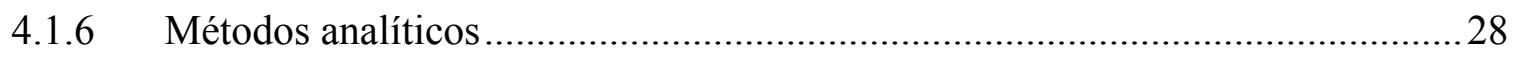

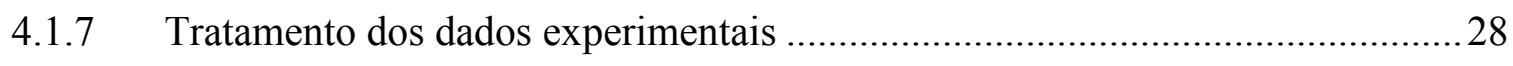

4.2 Ensaios nos Reatores Anaeróbios Horizontais de Leito Fixo (RAHLF) e no Reator Anaeróbio de Fluxo Ascendente e Manta de Lodo (UASB) .................................................30

4.2.1 Descrição do RAHLF ...................................................................................... 30

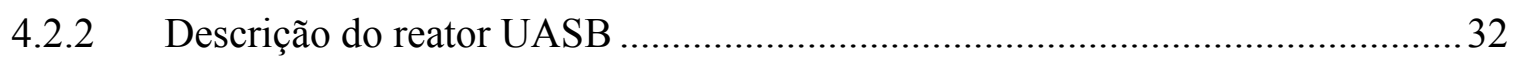

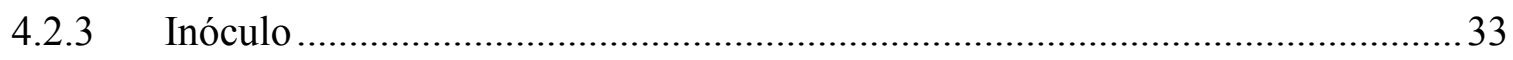

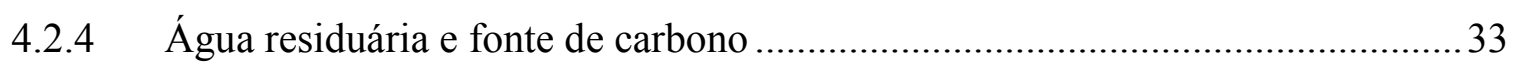

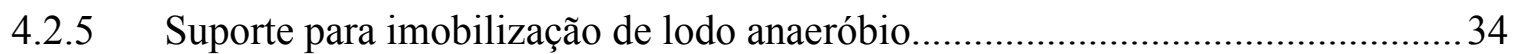

4.2.6 Preparo do leito do reator anaeróbio horizontal de leito fixo (RAHLF) ……......34

4.2.7 Análises físico-químicas ..................................................................................... 35 
4.2.8 Operação do reator anaeróbio horizontal de leito fixo (RAHLF) ...................... 36

4.2.9 Operação do reator anaeróbio de fluxo ascendente e manta de lodo (UASB)... 39

4.2.10 Monitoramento do reator anaeróbio horizontal de leito fixo (RAHLF) e do reator anaeróbio de fluxo ascendente (UASB) ........................................................... 41

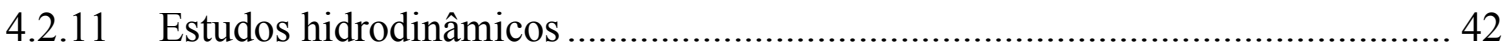

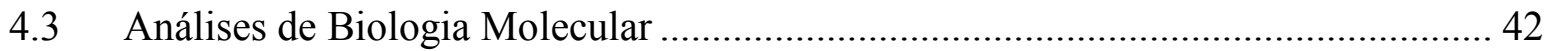

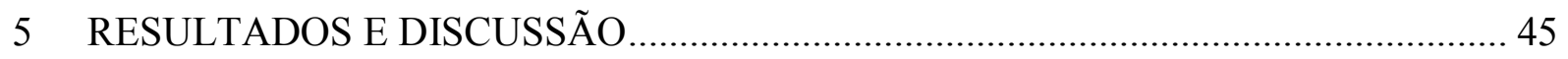

5.1 Ensaios de Imobilização da Biomassa em Espuma de Poliuretano.......................... 45

5.1.1 Variação temporal da biomassa aderida ao suporte ......................................... 45

5.1.2 Quantidade máxima de biomassa aderida ao suporte .................................... 48

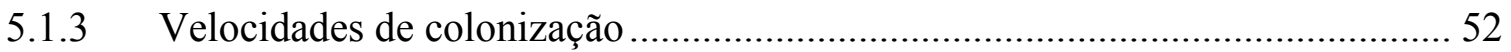

5.2 Determinação do padrão de escoamento dos reatores RAHLF e UASB antes do

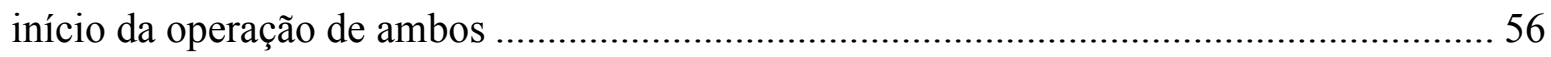

5.3 Ensaios nos Reatores Anaeróbios Horizontais de Leito Fixo - RAHLF ................... 62

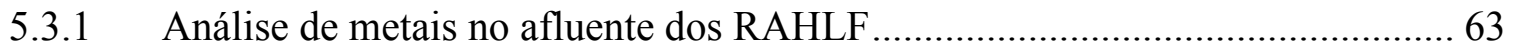

5.3.2 Análises de Monitoramento do RAHLF 1 (pH, DQO,concentrações de ácido

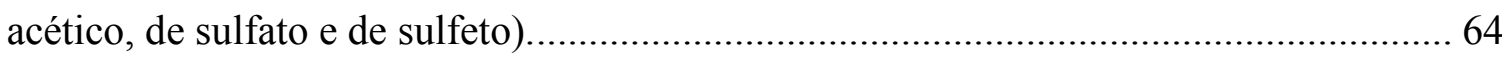

5.3.3 Análises de Monitoramento do RAHLF 2 (pH, DQO,concentrações de ácido

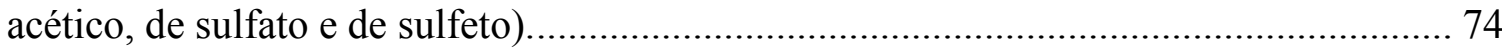

5.3.4 Análises de Monitoramento do RAHLF 3 (pH, DQO,concentrações de ácido

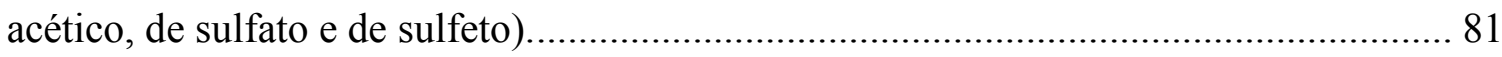

5.3.5 Análise Comparativa dos Reatores Anaeróbios Horizontais de Leito Fixo ( $\mathrm{pH}$, DQO,concentrações de ácido acético, de sulfato e de sulfeto)...................................... 92

5.3.6 Perfis espaciais de parâmetros nos RAHLF...................................................... 94

5.3.6.1 Análise do perfil espacial do reator R1 ..................................................... 94

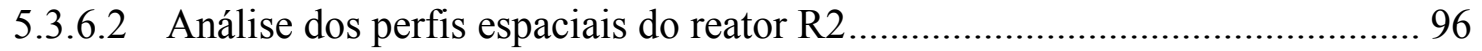

5.3.6.3 Análise dos perfis espaciais do reator R3 ................................................ 101

5.3.7 Avaliação da diversidade microbiana dos reatores RAHLF por técnicas biologia

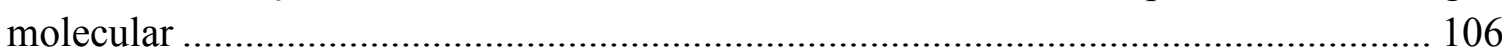

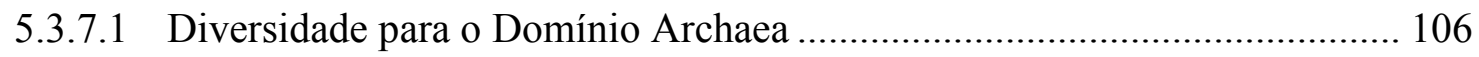

5.3.7.2 Diversidade para o Domínio Bacteria ........................................................... 109

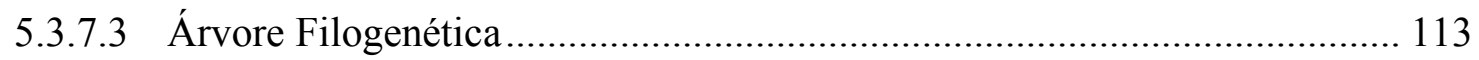

5.3.8 Balanço de massa dos reatores RAHLF ......................................................... 126

5.3.8.1 Resultados do balanço de massa para o reator R1 ..................................... 127

5.3.8.2 Resultados do balanço de massa para o reator R2 ...................................... 130 
5.3.8.3 Resultados do balanço de massa para o reator R3 .... 132

5.4 Ensaios no Reator Anaeróbio de Fluxo Ascendente e Manta de Lodo - UASB ..... 134

5.4.1 Etapa A de operação dos reatores UASB ….................................................... 134

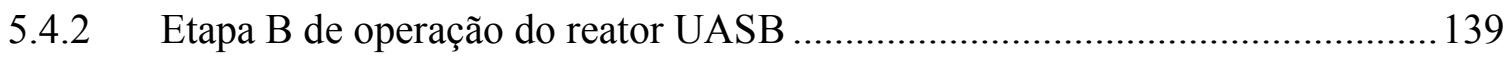

5.4.2.1 Análises de monitoramento ..................................................................... 139

5.4.2.2 Perfis espaciais do reator UASB na etapa B (fases II e IV)......................... 149

5.4.2.3 Balanço de massa do reator UASB (etapa B) ............................................ 156

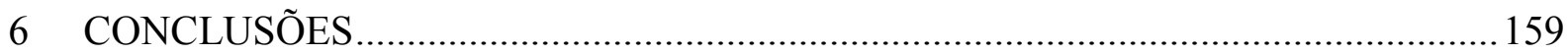

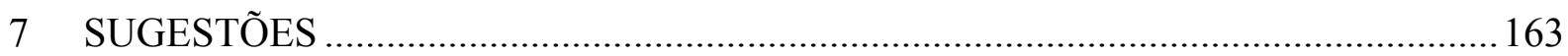

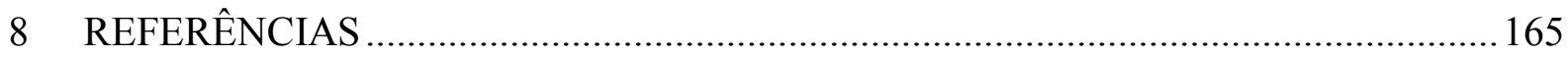




\section{CAPÍTULO 1}

\section{INTRODUÇÃO}

O impacto das atividades antropogênicas sobre o ciclo do enxofre resulta, ao longo do tempo, em sérios problemas ambientais, como: chuva ácida, odores ofensivos (em rios, aterros sanitários ou sistemas de tratamento), corrosão de aço e concreto, liberação de metais pesados de sedimentos e minérios expostos ao ar, entre outros. Entretanto, o combate à poluição causada pelo enxofre e metais pesados tem recebido menor atenção do que aquela despendida ao combate à poluição causada por carbono, nitrogênio e fósforo.

A mais significativa fonte de poluição causada pelo enxofre, em termos de volume, são as águas residuárias ricas em sulfato, oriundas da indústria de mineração, especialmente a indústria de carvão e de metais pesados. A drenagem ácida de minas (DAM) resulta da oxidação de minérios que contêm sulfeto (principalmente a pirita) a ácido sulfúrico e da solubilização de metais pesados devido aos baixos valores de $\mathrm{pH}$, fatores estes que podem comprometer a vida aquática nos corpos receptores, além de inviabilizar o uso desta água para o abastecimento doméstico ou comercial.

Os tratamentos disponíveis para as DAMs envolvem processos físico-químicos e processos biotecnológicos. Os primeiros baseiam-se na adição de compostos alcalinos que resultam na elevação do $\mathrm{pH}$ e precipitação dos metais pesados. Entretanto, esses são processos de alto custo e que geram resíduos de difícil disposição. Por sua vez, os tratamentos biológicos que envolvem a redução do sulfato apresentam inúmeras vantagens, como a remoção de metais pesados, o menor custo de disposição do lodo gerado, com a possibilidade, ainda, de recuperação desses metais e a geração de alcalinidade para o combate à acidez de certos efluentes. Uma vantagem adicional deste processo é a possibilidade de recuperação de 
enxofre elementar $\left(\mathrm{S}^{0}\right)$ a partir do sulfeto gerado na etapa anaeróbia do reator. $\mathrm{O}$ enxofre recuperado pode ser separado da fase líquida e utilizado como fertilizante ou como substrato em processos de biolixiviação.

$\mathrm{Na}$ tentativa de elucidar alguns pontos da redução de sulfato em águas ácidas de minas, avaliou-se, nesse trabalho, a operação contínua de dois tipos de reatores anaeróbios, um com crescimento aderido e outro com crescimento granular com o objetivo de estabelecer as melhores condições operacionais e as melhores eficiências na remoção de sulfato de águas residuárias da indústria de mineração. Em cada reator foi avaliada a influência dos seguintes parâmetros: relação $\mathrm{DQO} / \mathrm{SO}_{4}{ }^{2-}$, carga orgânica e de sulfato aplicadas, inserção de recirculação, correção de $\mathrm{pH}$ afluente (somente no reator com crescimento aderido) e volume da manta de lodo (somente no reator com crescimento granular). 


\section{CAPÍTULO 2}

\section{OBJETIVOS}

Os principal objetivo deste projeto foi:

Investigar e comparar processos redutores de sulfato em drenagens ácidas de minas, utilizando para tal dois reatores anaeróbios, um com biomassa imobilizada (reator anaeróbio horizontal de leito fixo - RAHLF) e outro com biomassa não aderida (UASB - upflow anaerobic sludge blanket);

Os objetivos específicos incluíram:

a. Estudar o processo de aderência microbiana em espuma de poliuretano em reatores diferenciais alimentados com drenagem ácida de mina utilizando para isso dois tipos de inóculo e três diferentes fontes de carbono;

b. Determinar o tipo de fonte de carbono a ser utilizada nos ensaios dos reatores RAHLF e UASB e investigar a possibilidade de obtenção de um inóculo a partir do sedimento da região da mina;

c. Analisar a influência, sobre a remoção de DQO e sulfato, do pH afluente, da carga de sulfato, da relação $\mathrm{DQO} / \mathrm{SO}_{4}{ }^{2-}$ e da recirculação da fase líquida no tratamento da drenagem ácida nos RAHLF;

d. Estudar a influência, sobre a remoção de DQO e sulfato, do volume da manta de lodo, da carga de sulfato, da relação $\mathrm{DQO} / \mathrm{SO}_{4}{ }^{2-}$ e da inserção de recirculação no tratamento da drenagem ácida no reator UASB. 


\section{CAPÍTULO 3}

\section{REVISÃO DA LITERATURA}

\subsection{Caracterização da Atividade Mineradora}

A história do Brasil tem íntima relação com a busca e o aproveitamento dos seus recursos minerais. Na Conferência Rio +10 , realizada em 2002, em Johannnesburgo, a mineração foi considerada uma atividade fundamental para o desenvolvimento econômico e social de muitos países, tendo em vista que os minerais são essenciais para a vida moderna (Farias, 2002). Entretanto, até por volta da segunda metade do século passado, as atividades de mineração eram realizadas sem a devida preocupação com a preservação do meio ambiente e da saúde humana. Os rejeitos de baixo teor e estéreis eram descartados ou abandonados sem que fossem considerados os possíveis efeitos impactantes, uma vez que não havia uma legislação específica e, consequentemente, uma fiscalização eficaz (Nascimento, 1998).

Atualmente, busca-se minimizar os impactos oriundos das atividades de mineração de forma a promover o desenvolvimento sustentável. Pesquisas, desenvolvimento de novos processos e aplicação de tecnologias mais modernas vêm sendo realizadas com a finalidade de reduzir ou tratar os rejeitos produzidos nas atividades atuais, bem como naquelas já finalizadas. 


\subsection{Drenagem Ácida de Mina}

Um dos problemas ambientais graves originados da atuação da indústria de mineração é a drenagem ácida de mina. As principais fontes de drenagens ácidas são as minas a céu aberto ou subterrâneas, bacia de rejeitos, pilhas do estéril e de estocagem do minério que contenham sulfetos associados (Nascimento, 1998)

Em muitos países já existem minas desativadas ou temporariamente fechadas, onde a drenagem ácida, procedente de rejeito e estéril, apresenta características de acidez bastante pronunciada ( $\mathrm{pH}$ entre 2 e 3). No Brasil, na região carbonífera ao sul do país e na Unidade de Tratamento de Minérios - Indústrias Nucleares do Brasil UTM/INB em Poços de Caldas, o problema da drenagem ácida de mina tem se destacado.

Os efeitos ambientais das DAM são muito sérios e extensos. O baixo valor do $\mathrm{pH}$, o baixo potencial osmótico, a presença de metais tóxicos e a formação e deposição de materiais particulados podem resultar em estresse e morte de populações nativas (macro- e microbiana) dos corpos d'água receptores, resultando em redução da biodiversidade. Adicionalmente, estas águas impactadas não podem ser utilizadas como uma fonte de águas para uso doméstico ou comercial.

A drenagem ácida de minas acontece quando a pirita $\left(\mathrm{Fe}_{2} \mathrm{~S}\right)$ e outros minerais contendo sulfetos são oxidados espontaneamente, devido à presença de oxigênio e água, produzindo ácido sulfúrico que dissolve metais presentes no solo/rocha. (Nordwick, 2003). A primeira etapa do processo envolve a oxidação do sulfeto metálico (reação 3.1) e pode ocorrer de forma abiótica, mas a velocidade da reação pode ser muito aumentada na presença de certos procariotos litotróficos. Esses microrganismos aceleram a oxidação do mineral pela geração do íon férrico (reação 3.2): 


$$
\begin{aligned}
& \mathrm{Fe}_{2} \mathrm{~S}+6 \mathrm{Fe}^{+3}+3 \mathrm{H}_{2} \mathrm{O} \rightarrow 7 \mathrm{Fe}^{+2}+\mathrm{S}_{2} \mathrm{O}_{3}^{-2}+6 \mathrm{H}^{+} \\
& 4 \mathrm{Fe}^{+2}+\mathrm{O}_{2}+4 \mathrm{H}^{+} \rightarrow 4 \mathrm{Fe}^{+3}+2 \mathrm{H}_{2} \mathrm{O}
\end{aligned}
$$

Algumas espécies dos grupos Bacteria e Archaea podem oxidar o tiossulfato (produto da oxidação da pirita), assim como outros compostos inorgânicos de enxofre e enxofre elementar, produzindo ácido sulfúrico (reação 3.3). Em pH entre 2,3 e 3,5, o íon férrico precipita como $\mathrm{Fe}(\mathrm{OH})_{3}$ e jarosita (Akcil e Koldas, 2006), disponibilizando íons $\mathrm{H}+$ em solução que contribuem para o abaixamento de pH (reação geral 3.4).

$$
\begin{aligned}
& \mathrm{S}_{2} \mathrm{O}_{3}{ }^{-2}+2 \mathrm{O}_{2}+\mathrm{H}_{2} \mathrm{O} \rightarrow 2 \mathrm{H}^{+}+2 \mathrm{SO}_{4}{ }^{-2} \\
& \mathrm{Fe}^{+3}+3 \mathrm{H}_{2} \mathrm{O} \rightarrow \mathrm{Fe}(\mathrm{OH})_{3}+3 \mathrm{H}^{+}
\end{aligned}
$$

Os fatores primários que determinam a velocidade de geração de águas ácidas em minas são, principalmente, o pH, a temperatura, a presença de oxigênio, a presença de água, a atividade química do $\mathrm{Fe}^{3+}$, a área superficial dos sulfetos metálicos e a atividade bacteriana (Akcil e Koldas, 2006).

Os principais microrganismos responsáveis pela dissolução dos sulfetos metálicos são as bactérias acidofílicas extremas (pH ótimo abaixo de 3) que são capazes de oxidar tanto os compostos inorgânicos de enxofre como o íon ferroso. Em função da limitada disponibilidade de substratos nos ambientes de mineração, esperar-se-ia uma baixa diversidade da flora microbiana presente. Entretanto, já é sabido que pelo menos 11 diferentes divisões de 
procariotos podem ser encontradas nesses ambientes contendo drenagem ácida (Baker e Banfield, 2003).

O mais clássico representante dessa biota é o grupo pertencente ao gênero Acidithiobacillus (anteriormente Thiobacillus, Kelly e Wood, 2000), incluindo as bactérias At. ferrooxidans e At. thiooxidans. Dentro desse gênero, encontra-se, ainda, uma bactéria termofílica, At. caldus, todos pertencentes à família $\delta$-Proteobacteria. Outros gêneros com capacidade de biolixiviação dentro dessa família são o Acidiphilium e Leptospirilium (Rohwerder et al., 2003). Bactérias Gram-negativas também foram descritas como flora de ambientes de biolixiviação, entre elas, os gêneros Acidimicrobium, Ferromicrobium e Sulfobacillus (Clark e Norris, 1996; Johnson e Roberto, 1997; Norris et al., 1996).

Com grande diversidade metabólica, a bactéria At. ferroxidans, além de oxidar compostos reduzidos de enxofre, possui a capacidade de oxidar o hidrogênio molecular, o ácido fórmico, o íon ferroso e outros metais. O crescimento em ambientes anaeróbios também já foi observado e é possível pela oxidação de compostos de enxofre ou hidrogênio acoplados a redução do íon férrico (Pronk et al., 1992; Das et al., 1992, Ohmura et al., 2002). Ohmura et al. (2002) também demonstraram que o At. ferrooxidans pode reduzir anaerobiamente o enxofre elementar juntamente com a oxidação do hidrogênio. A utilização de outros receptores de elétrons é possível devido à presença de vários transportadores de elétrons. Pelo menos, 11 diferentes citocromos do tipo $c$ já foram identificados no genoma do $A t$. ferrooxidans (Yarzábal et al., 2002).

O fato de muitas bactérias lixiviadoras controlarem de maneira completa os ciclos do enxofre e do ferro tanto aeróbia quanto anaerobiamente pode ser especialmente importante no tratamento da drenagem ácida de mina. Se a biolixiviação natural de pilhas de rejeitos e taludes for interrompida por coberturas orgânicas/vegetais, na tentativa de se criar ambientes 
anóxicos, as bactérias poderiam continuar ativas devido às suas capacidades de crescimento em condições anaeróbias. Entretanto, a lixiviação de pirita e sulfetos metálicos nessas condições anaeróbias ainda não foi demonstrada (Rohwerder et al., 2003).

\subsection{Mina Osamu Utsumi}

A mina Osamu Utsumi está localizada no sudeste do complexo alcalino de Poços de Caldas (MG) onde o mineral urânio foi extraído entre 1974 e 1997. Neste período, a mina Osamu Utsumi produziu 1030 t de urânio, resultando na ocupação de 172 ha por rochas residuais (5 pilhas), um volume equivalente a $45.106 \mathrm{~m}^{3}$ de material rico em pirita suscetível a biolixiviação. A quantidade de $\mathrm{U}_{3} \mathrm{O}_{8}$ presente nas pilhas de rejeitos está abaixo de 200 ppm, enquanto a concentração de metais ( $\mathrm{Mn}, \mathrm{Zn}, \mathrm{Fe}$ e radionuclídeos) está acima daquela permitida pelo CONAMA (2005). No ano de 1997, a mina Osamu Utsumi começou a sofrer o processo de descomissionamento, que é definido como a demolição, desmantelamento ou remoção de uma operação de extração não mais necessária (ou deteriorada), que inclui o trabalho de despoluição e torna o local disponível para uso irrestrito.

A Tabela 3.1 mostra as principais características físico-químicas da drenagem ácida produzida em uma das pilhas de rejeito da Mina Osamu Utsumi (Benedetto et al., 2005).

Tabela 3.1. Caracterização físico-química da drenagem ácida da mina Osamu Utsumi.

\begin{tabular}{lccccc}
\hline Local & $\mathbf{p H}$ & $\begin{array}{c}\text { Matéria orgânica } \\
\left(\mathbf{m g ~ l}^{-1}\right)\end{array}$ & $\begin{array}{c}\mathbf{S O}_{\mathbf{4}}{ }^{-2} \\
\left(\mathbf{m g ~ l}^{-\mathbf{1}}\right)\end{array}$ & $\begin{array}{c}\mathbf{M n} \\
\left(\mathbf{m g ~ l}^{-\mathbf{1}}\right)\end{array}$ & $\begin{array}{c}\mathbf{Z n} \\
\left(\mathbf{m g ~ l}^{\mathbf{1}}\right)\end{array}$ \\
\hline BF8 & 3,50 & 0,005 & 1550,0 & 137,6 & 22,6 \\
\hline
\end{tabular}

BF8: bota-fora 8 (fonte Benedetto et al, 2005). 
Vale lembrar que a pirita é o mineral comumente encontrado em minérios (inclusive na mina Osamu Utsumi). O grande problema desta mina é que o potencial de geração de drenagem ácida (ou seja, para que toda a pirita seja oxidada) é maior que mil anos. Portanto, o processo de descomissionamento só terminaria quando a geração da drenagem ácida (que precisa ser tratada) terminar. Assim, a geração de drenagem ácida de minas neste local é um grande passivo ambiental para a companhia proprietária, com um custo bastante elevado no tratamento empregado atualmente, que se baseia na adição de hidróxidos para o aumento do pH e a precipitação dos metais pesados.

As diversas unidades da mina incluem, desde as unidades de extração (Figura 3.1) e processamento de minérios (Figura 3.2), até a unidade de tratamento da drenagem ácida de minas (Figura 3.3).

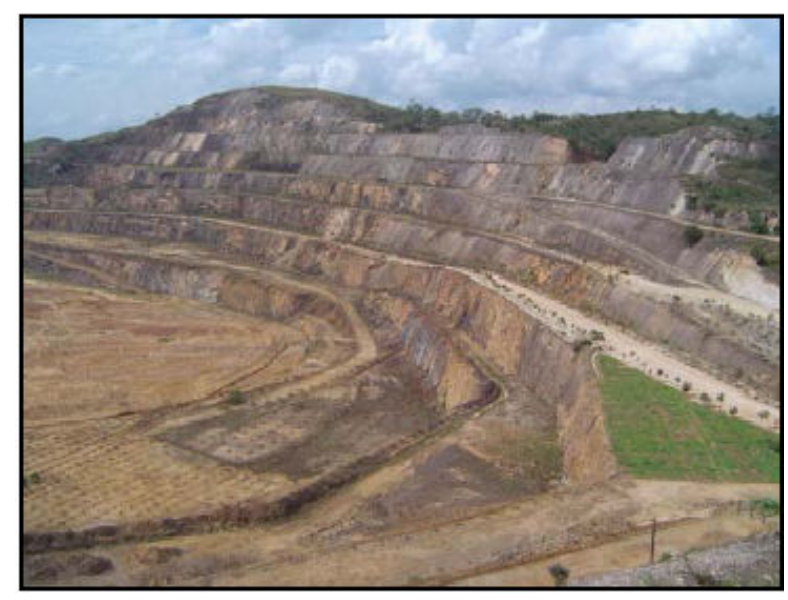

Figura 3.1. Vista geral da cava da mina Osamu Utsumi. 

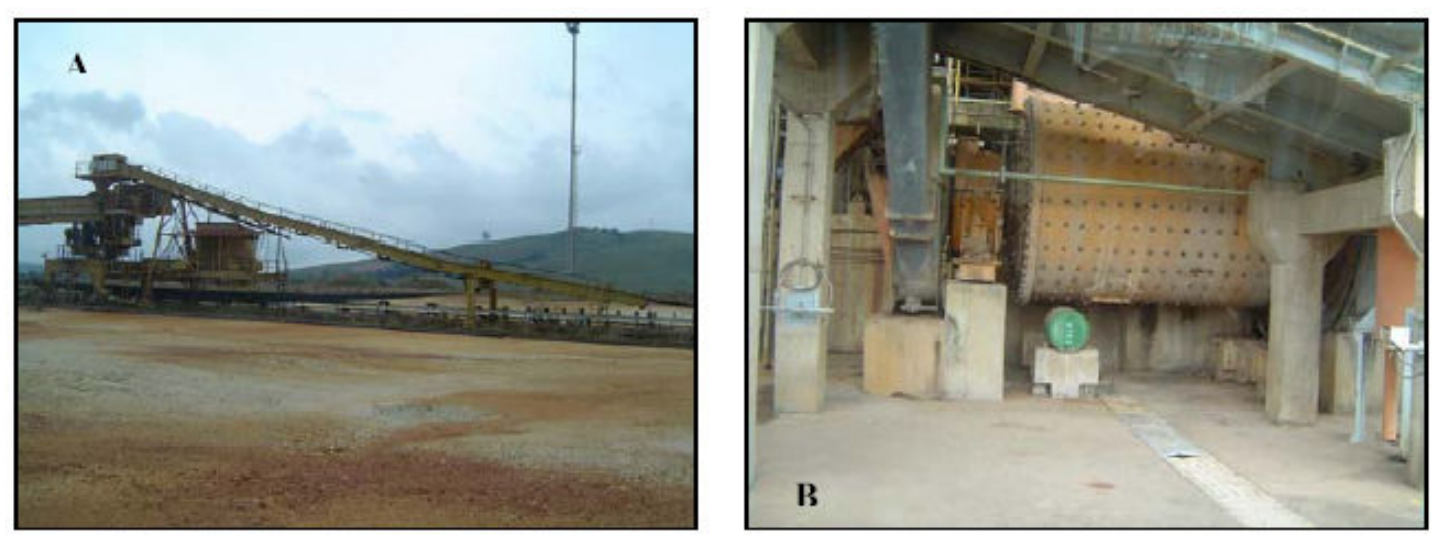

Figura 3.2.Visão geral das unidades desativadas do processamento de minério na mina Osamu Utsumi. (A) Mineroduto que conduzia o minério da extração até as unidades físicas de redução de tamanho do minério. (B) Tambor onde ocorria a operação de moagem do minério.
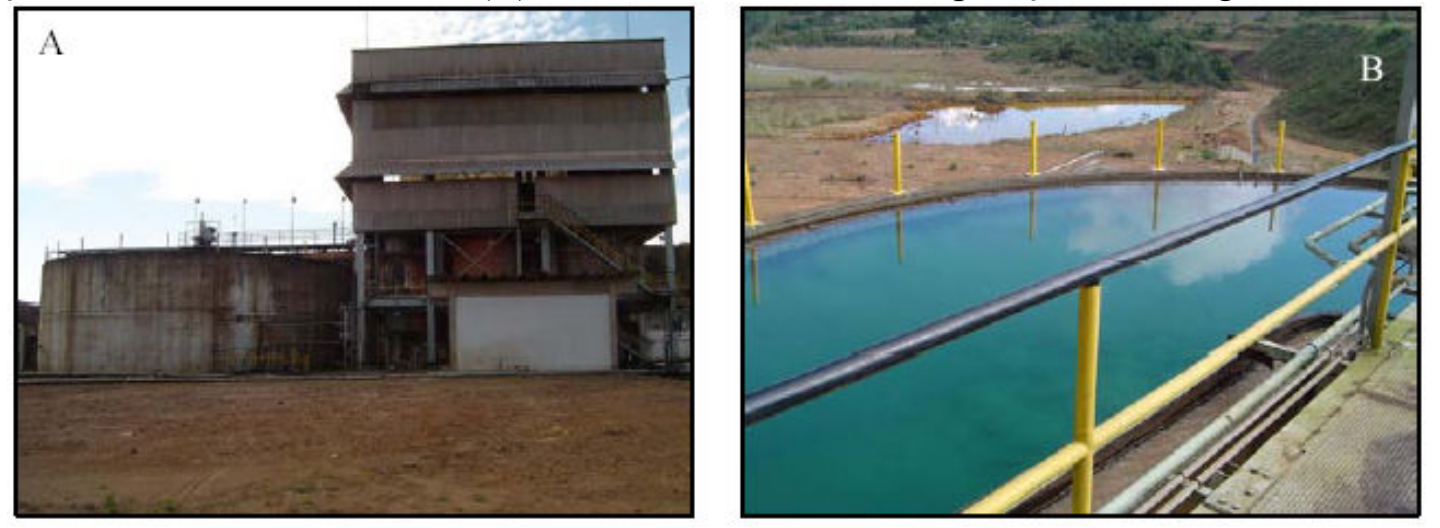

Figura 3.3.Visão geral da unidade de tratamento de DAM da mina Osumi Utsumi. (A) Tanques do preparo da cal e de mistura (à direita, com cobertura) e do tanque de sedimentação (à esquerda). (B) Visão superior do tanque de sedimentação, onde há formação e separação do precipitado de sulfato de cálcio e metais.

\subsection{O Ciclo do Enxofre}

As (bio)transformações do ciclo do enxofre foram uma das maiores forças propulsoras para muitas formas de vida no início do planeta. Com o estabelecimento das condições aeróbias na Terra, o ciclo do enxofre sofreu grandes consequências. A partir de então, o enxofre não somente atuaria como um doador ou receptor de elétrons na respiração anaeróbia, mas também seria utilizado como uma fonte de energia na produção de ATP. 
Na natureza, os estoques de enxofre são, principalmente, o gesso $\left(\mathrm{CaSO}_{4}\right)$, os sulfetos metálicos e o enxofre elementar $\left(\mathrm{S}^{0}\right)$. $\mathrm{O}$ aumento da atividade antropogênica foi responsável por um desequilíbrio nas conversões do ciclo do enxofre com geração de inúmeros tipos de poluição, entre elas a chuva ácida e a corrosão, além da formação de sulfetos tóxicos e liberação de metais pesados resultantes da mineração (Lens e Kuenen, 2001).

As tecnologias ambientais que envolvem o ciclo do enxofre devem estar baseadas na formação de intermediários insolúveis que podem ser separados da fase líquida, de preferência, que sejam pertencentes aos estoques existentes na natureza.

As conversões do ciclo do enxofre envolvem reações de oxidação e redução e podem ser realizadas tanto química quanto biologicamente (Figura 3.4).

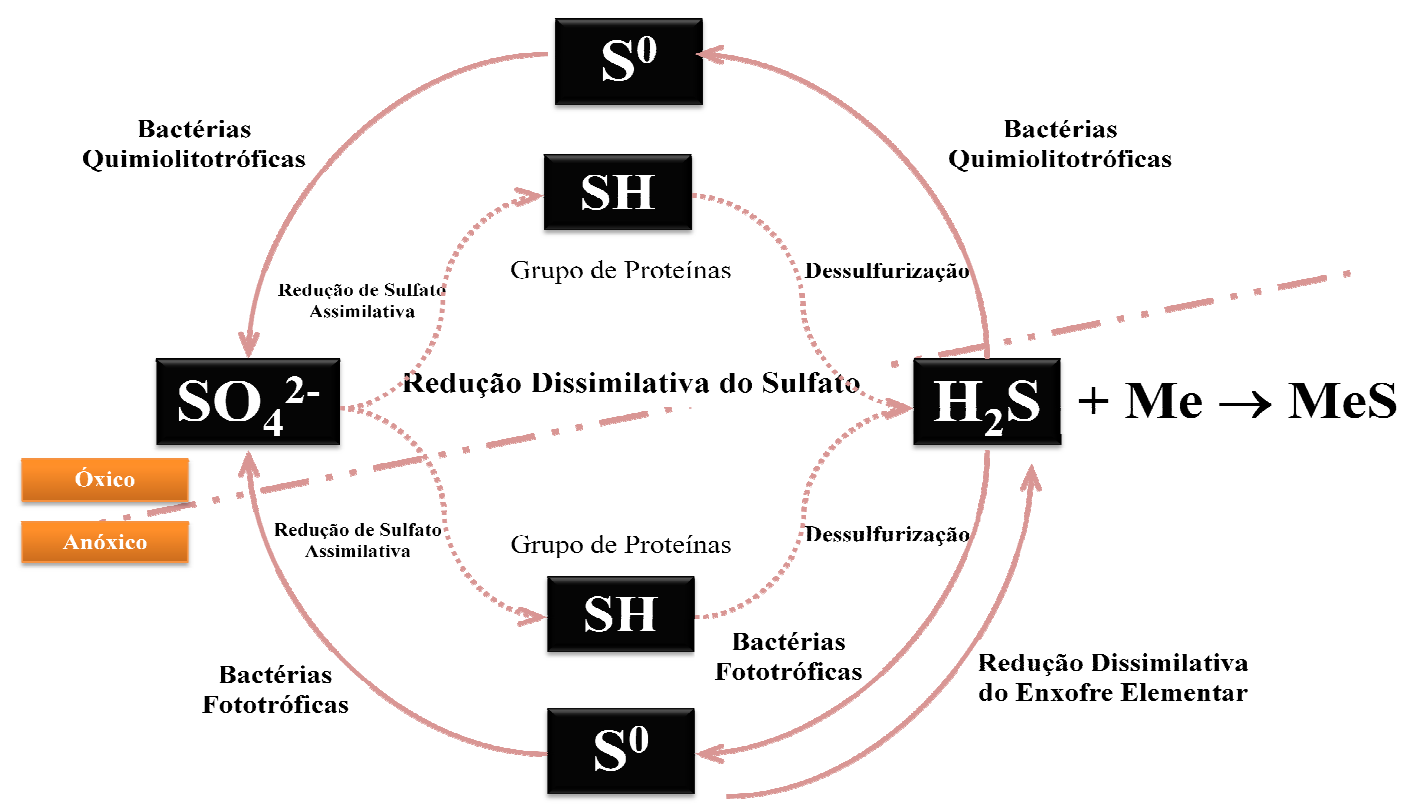

Figura 3.4. Ciclo do Enxofre (Lens e Kuenen, 2001)

Os microrganismos desempenham um papel importante nessas transformações. O íon sulfato, por exemplo, pode ser utilizado como um nutriente e reduzido a sulfeto, que é 
incorporado aos aminoácidos e enzimas. Reações de oxidação e redução para a geração de energia envolvem a oxidação de sulfeto por bactérias quimiolitoautotróficas e a redução dissimilativa por bactérias redutoras de sulfato (BRS).

As BRS são microrganismos encontrados em uma variedade de ambientes anóxicos e usam o sulfato como receptor final de elétrons para a degradação de compostos orgânicos com geração de sulfeto. O sulfeto, por sua vez, pode ser oxidado por bactérias aeróbias quimiolitoautotróficas ou em condições anóxicas por bactérias fototróficas. É estimado que a redução de sulfato seja responsável por mais de 50\% da mineralização de carbono orgânico em sedimentos marinhos, o que destaca a importância dos redutores de sulfato tanto no ciclo do enxofre como no ciclo do carbono (Muyzer e Stams, 2008).

\subsection{Microrganismos Redutores de Sulfato}

O grupo dos microrganismos redutores de sulfato é bastante heterogêneo e engloba representantes dos Domínios Bacteria e Archaea que têm em comum a capacidade de utilizar o sulfato como receptor final de elétrons (Hansen, 1994). Culturas já foram obtidas desde ambientes psicrófilos (Jorgensen e Bak, 1991) até hipertermofílicos (Stetter, 1988) e desde ambiente com concentrações de $\mathrm{NaCl}$ semelhantes às da água potável a ambientes hipersalinos (Caumette et al., 1991; Ollivier et al., 1991).

Esses microrganismos desempenham um papel importante na degradação anaeróbia quando o sulfato está presente como maior receptor de elétrons e, em alguns casos, quando o sulfato está ausente (Hansen, 1994). Além disso, o interesse nesse grupo de procariotos não está associado apenas aos problemas de corrosão anaeróbia que podem ocorrer nas redes de esgotos, mas ao seu potencial de utilização em sistemas de tratamento de águas ricas em 
sulfato e metais pesados ou no tratamento do dióxido de enxofre resultante da queima dos combustíveis fósseis (Tang et al., 2009).

Baseado nas análises comparativas de sequências do gene 16S rRNA, o grupo dos redutores de sulfato pode ser dividido em sete linhagens filogenéticas, sendo cinco pertencentes ao Dominio Bacteria e dois pertencentes ao Dominio Archaea. A maioria desses microrganismos está presente em 23 gêneros da família $\delta$-Proteobacteria, seguido pelas Grampositivas. Três linhagens, Nitrospirae, Thermodesulfobacteria e Thermodesulfobiaceae, contêm somente redutores de sulfato termofílicos. No Dominio Archaea, os representantes se dividem nos gêneros Archaeoglobus, do filo Euryarchaeota e nos gêneros Thermocladium e Caldivirga, da filo Crenarchaeota (Muyzer e Stams, 2008).

\subsubsection{Metabolismo das bactérias redutoras de sulfato}

O nome "bactéria redutora de sulfato" é convencionalmente reservado para microrganismos que conduzem a redução dissimilatória do sulfato. Nesse processo o íon sulfato atua como um agente oxidante para a dissimilação da matéria orgânica. Entretanto, apenas uma pequena parcela do enxofre reduzido é assimilada pelos microrganismos, sendo a maior parte excretada na forma de íon sulfeto normalmente hidrolisado a $\mathrm{H}_{2} \mathrm{~S}$ em $\mathrm{pH}$ abaixo de 8,0 (Jain, 1995).

Do ponto de vista químico, a utilização de sulfato como receptor de elétrons é uma reação bastante desfavorável. O potencial redox $\left(E^{0}\right)$ do par sulfato-sulfito é -516 mV, ou seja, muito negativo para permitir a redução pelo $\mathrm{NADH}$, cujo potencial redox é de $-314 \mathrm{mV}$ (Muyzer e Stams, 2008). A redução do sulfato, portanto, ocorre no citoplasma após sua 
conversão em adenosina-fosfosulfato (APS) (Hansen, 1994). A formação da APS requer a ligação do sulfato a uma molécula de ATP, reação essa catalisada pela enzima ATP sulforilase. O par APS-sulfito possui um potencial redox de $-60 \mathrm{mV}$, permitindo a redução do sulfato a sulfito pela enzima APS redutase. O sulfito é convertido a sulfeto pela enzima sulfito redutase e o sulfeto é, por fim, excretado pela célula (Tang et al., 2009). As etapas de conversão do sulfito a sulfeto ainda não são bem compreendidas, porém, parecem envolver intermediários como o tritionato e o tiosulfato (Muyzer e Stams, 2008).

A Figura 3.5 apresenta a conversão do sulfato a APS, e sua redução até sulfeto de hidrogênio.

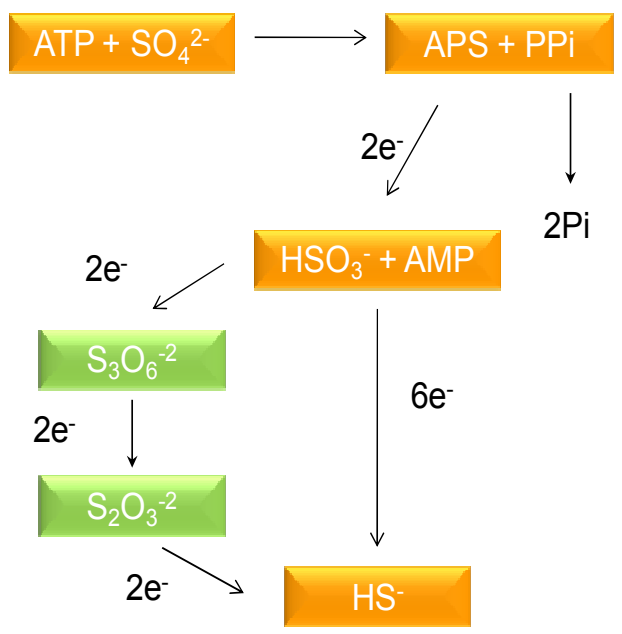

Figura 3.5. Etapas da conversão de sulfato a APS e redução a $\operatorname{HS}^{-}$(Hansen, 1994).

Hansen (1994) descreve que grande parte das bactérias redutoras de sulfato realiza como via preferencial a oxidação incompleta do substrato quando o etanol está presente como doador de elétrons. A oxidação do etanol a acetaldeído e, em seguida, a acetato é uma reação mediada pela enzima álcool desidrogenase NAD-dependente, presente em muitas espécies de bactérias redutoras de sulfato, como exemplifica o autor. 
Em ambientes aeróbios, o sulfato é termodinamicamente estável e em ambientes reduzidos, o sulfeto é mais estável. No entanto, a redução de sulfato a sulfeto não ocorre espontaneamente e requer uma mediação catalítica por atividade biológica.

As BRS possuem a capacidade de metabolizar uma grande variedade de compostos, desde hidrogênio, ácidos carboxílicos, álcoois, açúcares e aromáticos substituídos. A oxidação dos substratos orgânicos pode ocorrer completamente ou de maneira incompleta, sendo acetato o produto final. A Figura 3.6 ilustra as rotas metabólicas de degradação de moléculas orgânicas complexas quando o sulfato está presente como receptor de elétrons.

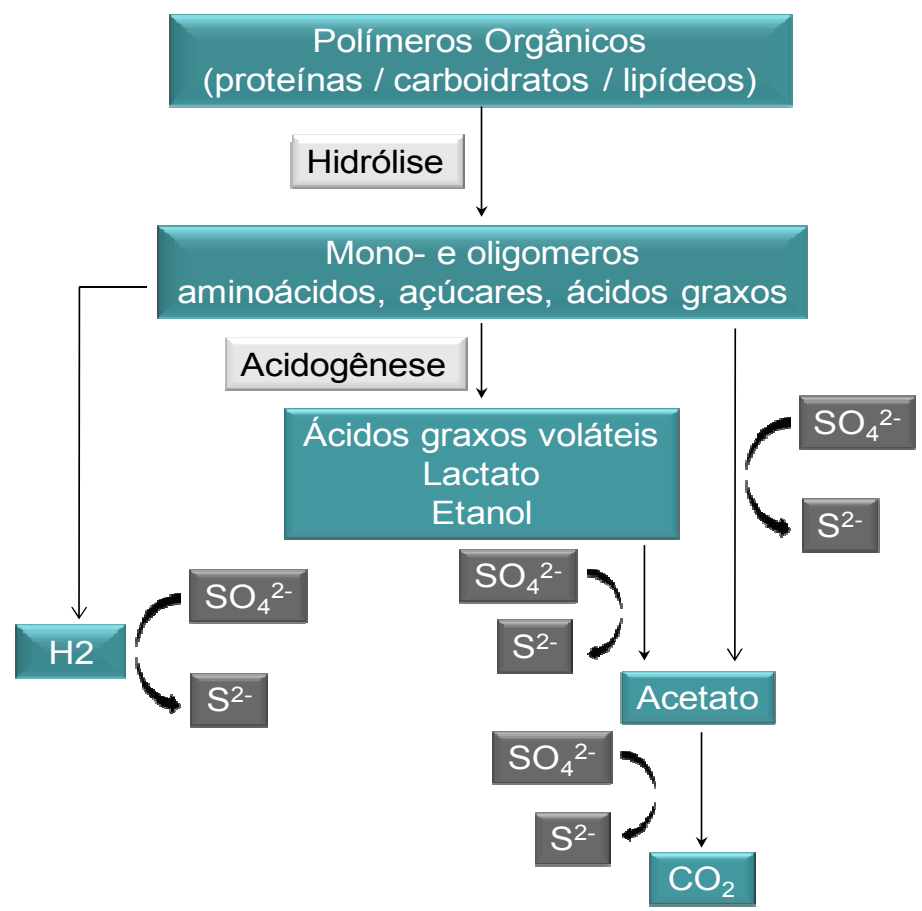

Figura 3.6. Etapas de degradação da matéria orgânica na presença de sulfato (Muyzer e Stams, 2008).

A escolha do doador de elétrons em processos redutores de sulfato será dependente da sua aplicação e das variáveis mais importantes em cada caso, entre elas a disponibilidade do doador de elétrons, o custo, a maior ou menor geração de acetato, a existência de competição 
com as arqueias metanogênicas e a geração de alcalinidade. Além disso, o processo será diretamente influenciado pelo tipo de reator, tipo de inóculo, concentração de sulfato e de metais, temperatura de operação, $\mathrm{pH}$ e tempo de detenção hidráulica (Kaksonen e Puhakka, 2007).

A competição das arqueias metanogênicas pelos substratos acetato e $\mathrm{H}_{2}$, intermediários nos processos de redução de sulfato, podem reduzir a eficiência da remoção do mesmo se algumas estratégias não forem adotadas. Do ponto de vista termodinâmico, as BRS levam vantagem sobre o uso de acetato e hidrogênio, com variações de energia livre $\left(\Delta \mathrm{G}^{0}\right)$ mais negativas do que as metanogênicas. A Tabela 3.2 mostra a principais reações envolvendo a redução de sulfato, a metanogênese e a acetogênese.

Tabela 3.2. Variação de energia livre para as principais rotas de degradação anaeróbia da matéria orgânica (fonte: Muyzer e Stams, 2008).

\begin{tabular}{|c|c|}
\hline REAÇÃO & $\begin{array}{c}\Delta \mathrm{G}^{0} \\
(\mathrm{~kJ} / \text { reação) }\end{array}$ \\
\hline \multicolumn{2}{|l|}{ Redução de sulfato } \\
\hline $4 \mathrm{H}_{2}+\mathrm{SO}_{4}{ }^{2-}+\mathrm{H}^{+} \rightarrow \mathrm{HS}^{-}+4 \mathrm{H}_{2} \mathrm{O}$ & $-151,9$ \\
\hline Acetato $+\mathrm{SO}_{4}^{2-} \rightarrow \mathrm{HS}^{-}+2 \mathrm{HCO}_{3}^{-}$ & $-47,6$ \\
\hline Propionato $+0,75 \mathrm{SO}_{4}{ }^{2-} \rightarrow$ Acetato $+0,75 \mathrm{HS}^{-}+0,25 \mathrm{HCO}_{3}{ }^{-}+0,25 \mathrm{H}^{+}$ & $-37,7$ \\
\hline Butirato $+0,5 \mathrm{SO}_{4}{ }^{2-} \rightarrow 2$ Acetato $+0,5 \mathrm{HS}^{-}+0,5 \mathrm{H}^{+}$ & $-27,8$ \\
\hline Lactato $+0,5 \mathrm{SO}_{4}{ }^{2-} \rightarrow$ Acetato $+0,5 \mathrm{HS}^{-}+\mathrm{HCO}_{3}^{-}$ & $-80,2$ \\
\hline \multicolumn{2}{|l|}{ Acetogênicas } \\
\hline Propionato $+3 \mathrm{H}_{2} \mathrm{O} \rightarrow$ Acetato $+\mathrm{HCO}_{3}^{-}+\mathrm{H}^{+}+3 \mathrm{H}_{2}$ & $+76,1$ \\
\hline Buritato $+2 \mathrm{H}_{2} \mathrm{O} \rightarrow 2$ Acetato $+\mathrm{H}^{+}+3 \mathrm{H}_{2}$ & $+48,3$ \\
\hline Lactato $+2 \mathrm{H}_{2} \mathrm{O} \rightarrow$ Acetato $+\mathrm{HCO}_{3}^{-}+\mathrm{H}^{+}+3 \mathrm{H}_{2}$ & $-4,2$ \\
\hline \multicolumn{2}{|l|}{ Metanogênicas } \\
\hline $4 \mathrm{H}_{2}+2 \mathrm{HCO}_{3}^{-}+\mathrm{H}^{+} \rightarrow \mathrm{CH}_{4}+3 \mathrm{H}_{2} \mathrm{O}$ & $-135,6$ \\
\hline Acetato $+\mathrm{H}_{2} \mathrm{O} \rightarrow \mathrm{CH}_{4}+3 \mathrm{HCO}_{3}^{-}$ & $-31,0$ \\
\hline
\end{tabular}

A razão entre a variação da energia livre entre as BRS e as metanogênicas é 1,12 na reação com o hidrogênio e 1,54 na reação com o acetato (Harada et al., 1994). Além disso, as constantes cinéticas do modelo de Monod $\left(\mu_{\mathrm{m}}-\right.$ velocidade específica máxima de crescimento 
e $K_{S}$ - constante de saturação do subsrato) mostram que a razão $\mu_{m} / K_{S}$ é maior para as BRS do que para as metanogênicas, indicando maiores velocidades específicas de crescimento para as mesmas concentrações de substrato.

Em adição aos fatores temodinâmicos e cinéticos, o pH é outro parâmetro importante no controle dessa competição, visto que pode afetar a eficiência dos sistemas em função da presença de $\mathrm{H}_{2} \mathrm{~S}$ livre (Visser et al., 1996 e Koster et al., 1986). Em ambientes aquáticos, os íons sulfeto existem em três diferentes formas: $\mathrm{S}^{2-}, \mathrm{HS}^{-}$e $\mathrm{H}_{2} \mathrm{~S}$. As constantes de equilíbrio a

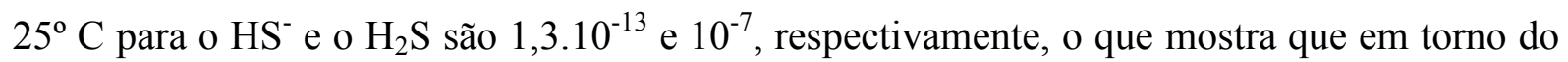
pH neutro a distribuição do $\mathrm{H}_{2} \mathrm{~S}$ se altera de maneira significativa (Hickey et al., 1991). O $\mathrm{H}_{2} \mathrm{~S}$ livre pode causar toxicidade acentuada nas arqueias metanogênicas ou impedir a formação de grânulos estáveis. Omil et al. (1996) mostraram que em baixos valores de pH, as metanogênicas foram severamente afetadas pela maior quantidade de $\mathrm{H}_{2} \mathrm{~S}$, enquanto as $\mathrm{BRS}$ não.

A concentração de íons sulfato, a $\mathrm{DQO}$ afluente e a razão $\mathrm{DQO} / \mathrm{SO}_{4}{ }^{2-}$ também são fatores que afetam a competição entre as BRS e as metanogênicas. Com o aumento da razão $\mathrm{DQO} / \mathrm{SO}_{4}{ }^{2-}$ as reações de metanogênese prevalecem sobre a sulfetogênese, enquanto com a proximidade dessa razão aos valores estequiométricos, nota-se aumento da atividade das BRS e da quantidade de sulfeto produzido (Mizuno et al., 1994).

Lens et al. (1998), em uma revisão sobre o tratamento biológico de águas residuárias ricas em sulfato, relatam que se a matéria orgânica for oxidada acoplada a redução do sulfato, 8 elétrons podem ser transferidos por molécula de íon sulfato. Como a capacidade de uma molécula de oxigênio é de aceitar 4 elétrons, tem-se que 2 mols de $\mathrm{O}_{2}$ equivalem a 1 mol de $\mathrm{SO}_{4}{ }^{-2}$ quanto a capacidade de receber elétrons. Ou seja, são $0,67 \mathrm{~g}$ de $\mathrm{O}_{2}$ por cada $1 \mathrm{~g}$ de $\mathrm{SO}_{4}{ }^{-}$ ${ }^{2}$. Isso significa que para águas residuárias com uma relação $\mathrm{DQO} / \mathrm{SO}_{4}{ }^{-2}$ de 0,67 , teoricamente 
existirá sulfato suficiente para remover completamente a matéria orgânica (DQO) via redução de sulfato. Para relações $\mathrm{DQO} / \mathrm{SO}_{4}{ }^{-2}$ inferiores a 0,67 , a quantidade de doadores de elétrons é insuficiente para reduzir completamente o sulfato presente e uma quantidade extra de matéria orgânica deverá ser suplementada se a remoção de sulfato for o objetivo do tratamento. Ao contrário, para águas residuárias com uma relação $\mathrm{DQO} / \mathrm{SO}_{4}{ }^{-2}$ superior a 0,67 , uma remoção completa da matéria orgânica poderá ocorrer se juntamente a redução de sulfato outros processos de oxidação da DQO estiverem presentes, como a metanogênese, por exemplo.

\subsection{Tratamento da Drenagem Ácida de Mina}

\subsubsection{Tratamentos físico-químicos}

O tratamento convencional utilizado para a drenagem ácida de mina é baseado na neutralização química e precipitação dos hidróxidos metálicos (Hao, 2000). Para a elevação do $\mathrm{pH}$ utiliza-se, normalmente, $\mathrm{Ca}(\mathrm{OH})_{2}$ e $\mathrm{CaO}$, que reagem com o sulfato presente na água ácida formando $\mathrm{CaSO}_{4} \cdot 2 \mathrm{H}_{2} \mathrm{O}$, que precipita. As desvantagens desse processo são o alto custo dos reagentes químicos, a baixa eficiência na remoção de sulfato e a produção de lodo, que deve ter disposição adequada (Garcia et al., 2001). A precipitação de sulfetos metálicos tem apresentado diversos benefícios sobre a precipitação com hidróxidos, como a menor concentração de metais no efluente e a possibilidade de recuperação desses metais (Veeken e Rulkens, 2003). Entretanto, a utilização da precipitação com sulfetos não tem sido amplamente utilizada para tratamento de DAM, talvez devido ao alto custo dos reagentes. 


\subsubsection{Tratamentos biológicos}

Muitos esforços têm sido desenvolvidos na busca por alternativas biológicas para o tratamento de DAM e a recuperação de metais. Inúmeros processos biológicos podem remover metais de águas residuárias, incluindo a biosorção, acúmulo intracelular, complexação, oxidação-redução, metilação combinada com volatilização e precipitação extracelular (Kaksonen e Puhakka, 2007). Além disso, muitos processos biológicos são capazes de gerar alcalinidade ou consumir acidez e, dessa forma, tem potencial para serem usados no tratamento da drenagem ácida. Os processos incluem fotossíntese (van Hille et al., 1999), desnitrificação (Johnson, 1995), amonificação, metanogênese e a redução dos íons ferro e sulfato (White et al., 1997).

A redução do sulfato, entretanto, ocupa lugar de destaque, por combinar a remoção de acidez, de sulfato e de metais. O processo está baseado na produção biológica de sulfeto e a geração de alcalinidade, segundo a reação 3.5,

$2 \mathrm{CH}_{2} \mathrm{O}+\mathrm{SO}_{4}{ }^{2-} \rightarrow \mathrm{H}_{2} \mathrm{~S}+2 \mathrm{HCO}_{3}^{-}$

na qual $\mathrm{CH}_{2} \mathrm{O}$ representa a molécula de um doador de elétron.

Quando o hidrogênio é usado como doador de elétrons na redução do sulfato, a reação gera íons hidroxila (reação 3.6):

$8 \mathrm{H}_{2}+\mathrm{SO}_{4}{ }^{2-} \rightarrow \mathrm{H}_{2} \mathrm{~S}+\mathrm{HS}^{-}+5 \mathrm{H}_{2} \mathrm{O}+3 \mathrm{OH}^{-}$ 
O sulfeto de hidrogênio produzido precipita os metais em solução, gerando sulfetos com baixa solubilidade (reação 3.7):

$\mathrm{H}_{2} \mathrm{~S}+\mathrm{M}^{2+} \rightarrow \mathrm{MS}(\mathrm{s})+2 \mathrm{H}^{+}$

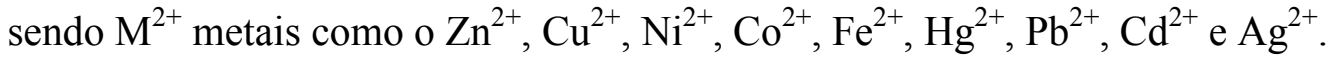

A precipitação dos sulfetos metálicos gera prótons, que podem conferir certa acidez à água tratada. Para tanto, um excesso de sulfato deverá ser reduzido para compensar essa acidez. O íon bicarbonato e os íons hidroxila produzidos na redução do sulfato podem neutralizar o baixo pH da água residuária (reações 3.8 e 3.9).

$$
\begin{aligned}
& \mathrm{HCO}_{3}{ }^{-}+\mathrm{H}^{+} \rightarrow \mathrm{CO}_{2}(\mathrm{~g})+\mathrm{H}_{2} \mathrm{O} \\
& \mathrm{OH}^{-}+\mathrm{H}^{+} \rightarrow \mathrm{H}_{2} \mathrm{O}
\end{aligned}
$$

A aplicação de processos biológicos de redução de sulfato no tratamento de águas de mineração tem sido extensivamente estudada e inúmeros tipos de tratamento já foram propostos e se dividem basicamente em processos passivos e processos ativos (Kaksonen e Puhakka, 2007).

Os tratamentos passivos para áreas contaminadas que estejam abaixo da superfície incluem o enriquecimento da atividade microbiana através da injeção de substrato adequado ou a inserção de barreiras permeáveis reativas (Benner et al., 1999). De fato, algumas BRS 
têm sido isoladas do fundo de lagoas de rejeitos de mineração. Do mesmo modo, tem sido provado que ecossistemas aquáticos contaminados por águas ácidas são capazes de recuperar naturalmente a situação inicial graças à presença de espécies com a capacidade para regenerar o meio (Luptakova \& Kusnierova, 2005; Garcia et al., 2001). No caso de áreas na superfície, são propostos as áreas de infiltração, lagoas anóxicas ou sistemas de "wetlands" (Hulshoff Pol et al., 2001). Todas essas alternativas como tratamento de DAM oferecem baixo custo e manutenção fácil, além de permitir o uso em áreas de mineração remotas. Entretanto, requerem grandes áreas, apresentam maior dificuldade para recuperação dos metais e estão mais sujeitas às variações sazonais.

Os tratamentos ativos em bioreatores contendo uma biomassa mais especializada e com maior controle do processo surgem, então, para contornar as desvantagens dos tratamentos passivos. Diferentes tipos de reatores para redução biológica de sulfato têm sido propostos na literatura, entre eles os reatores em batelada (Neculita e Zagury, 2008; Herrera et al., 1997), reatores de mistura com agitação contínua (White e Gadd, 1996), filtros anaeróbios (Maree e Strydom, 1985), reatores de leito fluidizado (Somlev e Banov, 1998), reatores UASB (Lima et al., 1996), reatores anaeróbios híbridos (Steed et al., 2000) e reatores de membrana (Mack et al., 2004).

Jiménez-Rodríguez et al. (2009) avaliaram a influência do pH sobre o tratamento de drenagem ácida de mina com relação a remoção de sulfato e metais. A remoção de metais observada foi uma função do $\mathrm{pH}$ inicial. Em $\mathrm{pH} 3,5$, a maior parte do ferro foi removida, enquanto $\mathrm{Cu}$ e $\mathrm{Zn}$ foram parcialmente removidos. $\mathrm{Em}$ pH 5,5, a remoção de metais aumentou consideravelmente, com porcentagens de remoção de 91,3\% para $\mathrm{Fe}, 96,1 \%$ para $\mathrm{Cu}, 79,0 \%$ para $\mathrm{Zn}$ e $99,0 \%$ para Al. 
Reatores em batelada foram operados por Neculita e Zagury (2008) por longo período de tempo (152 dias) para o tratamento de drenagem ácida de mina. Os autores utilizaram compostos complexos como doadores de elétrons e obtiveram remoções de sulfato de cerca de $100 \%$ em todas as situações avaliadas e sugerem que as relações $\mathrm{C} / \mathrm{N}$ e $\mathrm{DQO} / \mathrm{SO}_{4}{ }^{2-}$ são parâmetros chaves na biodegradabilidade de compostos orgânicas quando sulfato for o receptor de elétron principal.

Tsukamoto et al. (2004) avaliaram o tratamento biológico de drenagem ácida de minas em um reator em coluna, analisando as variáveis fonte de carbono, $\mathrm{pH}$ e temperatura. Os autores obtiveram remoções de sulfato superiores a $80 \%$ quando etanol foi utilizado como doador de elétrons, além de $93 \%$ de remoção de ferro. Também foi observado que o tratamento era eficiente mesmo em $\mathrm{pH}$ ácido $(\mathrm{pH}=2,5)$ e baixas temperaturas $\left(6^{\circ} \mathrm{C}\right)$. Entretanto, o processo mostrou-se mais eficiente quando o $\mathrm{pH}$ afluente era corrigido para 5,0.

Segundo os estudos, em escala piloto, realizados na Austrália por Jong e Parry (2003), o tratamento de água ácida em um biorreator de coluna anaeróbia contendo bactérias sulfato redutoras foi bastante eficaz, alterando o $\mathrm{pH}$ de 4,0 para cerca de 7,2, com remoção de mais de $80 \%$ do sulfato, além de remover mais de $97,5 \%$ de metais. Além disso, esse processo apresentou menores custos quando comparado a neutralização por adição de uma substância alcalina.

Elliot et al. (1998) realizaram testes para o tratamento de águas ácidas utilizando um biorreator de coluna de fluxo contínuo. Nesse estudo, o biorreator foi preparado com a adição de meio de cultivo Postgate B, sem a adição de sulfato de ferro para impedir a precipitação de sulfeto de ferro. $\mathrm{O} \mathrm{pH}$ do efluente era reduzido progressivamente e eram medidos o $\mathrm{pH}$ final e a concentração de sulfeto de hidrogênio produzido. Após um período de adaptação do 
consórcio de BRS presente no biorreator, verificou-se que o $\mathrm{pH}$ do efluente estava maior, bem como uma produção de sulfeto de hidrogênio decorrente da redução do sulfato dissolvido.

A literatura demonstra uma escassez de publicações no que se refere a influência da relação $\mathrm{DQO} / \mathrm{SO}_{4}{ }^{2-}$ e da carga de sulfato aplicada sobre o processo de remoção de sulfato de drenagem ácida de minas. Grande parte dos artigos enfoca a questão de controle do pH inicial e da utilização de um inóculo adaptado de redutoras de sulfato como parâmetros decisivos no sucesso do processo.

\subsection{Considerações Finais}

Em função dos resultados promissores de trabalhos publicados na literatura sobre a redução de sulfato em condições distintas, foi levantada uma hipótese sobre a possibilidade de remoção de sulfato de águas ácidas de minas em reatores anaeróbios. Entretanto, grande parte dos trabalhos sobre tratamento de drenagem ácida preconizam a necessidade de prétratamento no afluente, principalmente para correção de pH. Este trabalho, porém, preocupouse em oferecer alternativas de tratamento da DAM sem que fosse necessário algum tratamento prévio da água residuária. Para tanto, foram estudados dois tipos diferentes de reator anaeróbio, um com biomassa granular (UASB) e um com crescimento aderido (RAHLF), avaliando-se a influência de parâmetros de processo como ajuste de $\mathrm{pH}$ inicial, relação $\mathrm{DQO} / \mathrm{SO}_{4}{ }^{2-}$, carga de sulfato aplicada e recirculação da fase líquida. 


\section{CAPÍTULO 4}

\section{MATERIAL E MÉTODOS}

Os experimentos realizados incluíram os ensaios de aderência microbiana na espuma de poliuretano, a operação dos reatores anaeróbios de leito fixo (RAHLF) e a operação do reator anaeróbio de manta de lodo (UASB), ambos inoculados com lodo proveniente de abatedouro de aves em diferentes condições de alimentação afluente.

\subsection{Ensaios de Imobilização da Biomassa em Espuma de Poliuretano}

Os experimentos consistiram em avaliar a dinâmica da aderência microbiana em partículas de espuma de poliuretano. O objetivo principal do experimento foi, além de avaliar a aderência microbiana no material suporte, definir qual fonte de matéria orgânica adicionar nos ensaios no RAHLF e no reator UASB e qual inóculo utilizar.

\subsubsection{Reatores diferenciais}

Foram utilizados reatores diferenciais com $2,4 \mathrm{~cm}$ de comprimento e $2,9 \mathrm{~cm}$ de diâmetro e capacidade de $15 \mathrm{ml}$, confeccionados em vidro borossilicato, providos de tampa de teflon e vedados com anéis de borracha tipo o-ring, como mostra a Figura 4.1. Esse tipo de reator pode ser considerado como um elemento diferencial de um reator de leito fixo, simulando a dinâmica do biofilme em um dado elemento de volume do reator integral. 


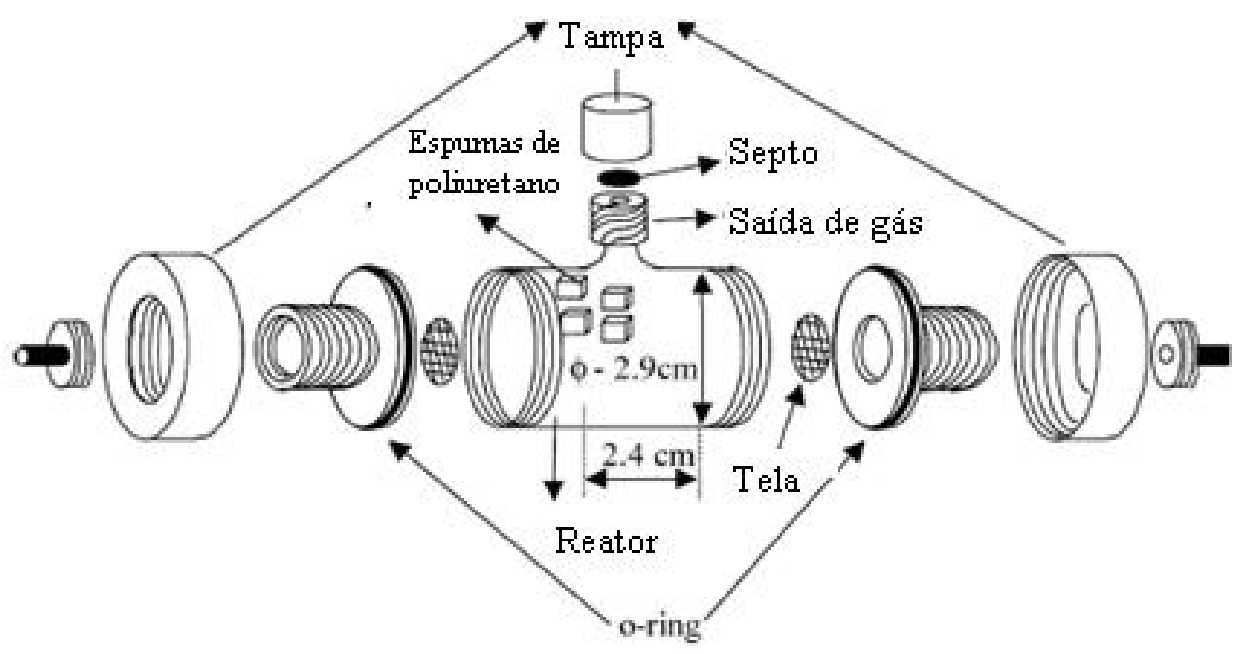

Figura 4.1. Reator diferencial (adaptado por Ribeiro, 2005).

\subsubsection{Suporte para imobilização da biomassa}

Cada reator foi preenchido com 60 partículas cúbicas de espuma de poliuretano de 0,5 cm de aresta, densidade aparente de $23 \mathrm{~kg} \mathrm{~m}^{-3}$, tamanho médio de poro de $543 \pm 154 \mu \mathrm{m}$ e área superficial de $43,8 \mathrm{~m}^{2} \mathrm{~g}^{-1}$.

\subsubsection{Inóculos}

Dois diferentes inóculos foram utilizados, um deles proveniente de um reator UASB aplicado ao tratamento de águas residuárias de abatedouro de aves (Avícola Dacar, SP Brasil) e outro proveniente do sedimento da mina de urânio Osamu Utsumi localizada em Poços de Caldas, MG - Brasil, ambos adicionados ao reservatório de afluente a uma

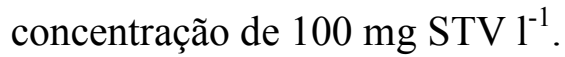




\subsubsection{Fontes de carbono}

Três fontes de carbono foram avaliadas separadamente, etanol, ácido lático e ácido fórmico, adicionados à DAM (obtida junto à Unidade de Tratamento de Minério Osamu Utsumi da Comissão Nacional de Energia Nuclear em Poços de Caldas - Minas Gerais) em concentração de aproximadamente $804 \mathrm{mg}^{-1}$ em termos de demanda química de oxigênio (DQO). Os reatores foram mantidos em uma incubadora (Marconi ${ }^{\circledR}$ ) para garantir a temperatura constante de $30^{\circ} \mathrm{C}$.

\subsubsection{Protocolo experimental}

Cada reator foi alimentado continuamente, sem recirculação da corrente efluente, com uma solução de DAM a uma velocidade superficial de $0,07 \mathrm{~cm} \mathrm{~min}^{-1}$, utilizando-se uma bomba peristáltica Gilson ${ }^{\circledR}$. A velocidade superficial foi definida em função da velocidade normalmente utilizada no reator horizontal de leito fixo (RAHLF) com TDH de $24 \mathrm{~h}$.

A DQO e a concentração de sulfato na corrente afluente foram de $804 \mathrm{mg} \mathrm{l}^{-1}$ e 1200 $\mathrm{mg} \mathrm{l}^{-1}$, respectivamente, resultando em uma relação $\mathrm{DQO} / \mathrm{SO}_{4}{ }^{2-}$ próxima de 0,67 . Esta relação foi definida em função da estequiometria da reação de redução do sulfato quando se observa oxidação completa da matéria orgânica.

Em intervalos de sete dias, um reator era retirado do aparato experimental e as matrizes colonizadas eram submetidas às análises de sólidos totais voláteis (STV) e a exames físico-químicos. 


\subsubsection{Métodos analíticos}

A determinação de STV foi realizada macerando-se as partículas cúbicas de espuma com um bastão de vidro em água destilada. Essa solução sem as espumas era submetida à secagem em estufa $105^{\circ} \mathrm{C}$ por $24 \mathrm{~h}$ e, em seguida, calcinada em mufla a $550^{\circ} \mathrm{C}$ por 15 minutos. O peso da espuma seca era determinado após $24 \mathrm{~h}$ de secagem em estufa a $105^{\circ} \mathrm{C}$.

As variáveis DQO (demanda química de oxigênio) e concentração de sulfato foram determinadas semanalmente de acordo com o Standard Methods for the Examination of Water and Wastewater (APHA, 2005).

\subsubsection{Tratamento dos dados experimentais}

Os dados experimentais de STV foram ajustados a uma sigmóide de Boltzman ou a uma hipérbole através do software Microcal Origin ${ }^{\circledR} 6.0$ e o algoritmo de LevenbergMarquardt (Marquardt, 1963) minimizando a somatória dos erros ao quadrado. Com o mesmo software, as curvas de concentração (C) em função do tempo (t) foram posteriormente derivadas para determinação das velocidades (v) de colonização, como expresso na equação 4.1.

$v=\frac{d C}{d t}$ 
As velocidades máximas $\left(\mathrm{v}_{\max }\right)$ foram calculadas para cada curva no ponto de máximo, como:

$$
v_{\max }=\frac{d v}{d t}=0
$$

As velocidades médias de colonização foram calculadas pela razão entre a integral das curvas derivadas e o tempo total de ensaio (28 dias):

$$
v_{\text {med }}=\frac{\int d v d t}{\int d t}
$$

Ribeiro et al. (2005) indicam a importância de se utilizar as velocidades máximas e médias na análise de curvas de crescimento em biofilme. No caso dos autores, as velocidades médias obtidas para as diferentes condições estudadas foram semelhantes, entretanto, observou-se diferença significativa nas velocidades máximas de colonização, resultando em comportamentos bastante distintos nas curvas de concentração de STV. 


\subsection{Ensaios nos Reatores Anaeróbios Horizontais de Leito Fixo (RAHLF) e no Reator Anaeróbio de Fluxo Ascendente e Manta de Lodo (UASB)}

Os ensaios em reator anaeróbio horizontal de leito fixo e reator anaeróbio de fluxo ascendente e manta de lodo objetivaram avaliar esses reatores como alternativas tecnológicas para tratamento de águas ácidas de drenagem de mina de urânio.

\subsubsection{Descrição do RAHLF}

O reator anaeróbio horizontal de leito fixo (RAHLF) em escala de bancada foi confeccionado em vidro borossilicato com $99,8 \mathrm{~cm}$ de comprimento e 5,04 $\mathrm{cm}$ de diâmetro (interno) perfazendo uma relação comprimento por diâmetro (L/D) de aproximadamente 20. O reator possui volume total de $1991 \mathrm{ml}$, sendo $1735 \mathrm{ml}$ de volume útil e $256 \mathrm{ml} \mathrm{(13 \%} \mathrm{do}$ total) destinados à separação do gás. Ao longo do comprimento, na parte superior do mesmo, foi instalada uma mangueira de silicone para coleta do gás gerado durante a operação do reator. Amostradores intermediários ao longo do comprimento do reator foram alocados em posições correspondentes a L/D (L:comprimento; D:diâmetro) de 3,3; 6,6; 10; 13,3 e 16,6.

O esquema das instalações experimentais para os ensaios com o RAHLF está apresentado na Figura 4.2, bem como uma fotografia dos reatores alocados na câmara de controle de temperatura (Figura 4.3). 


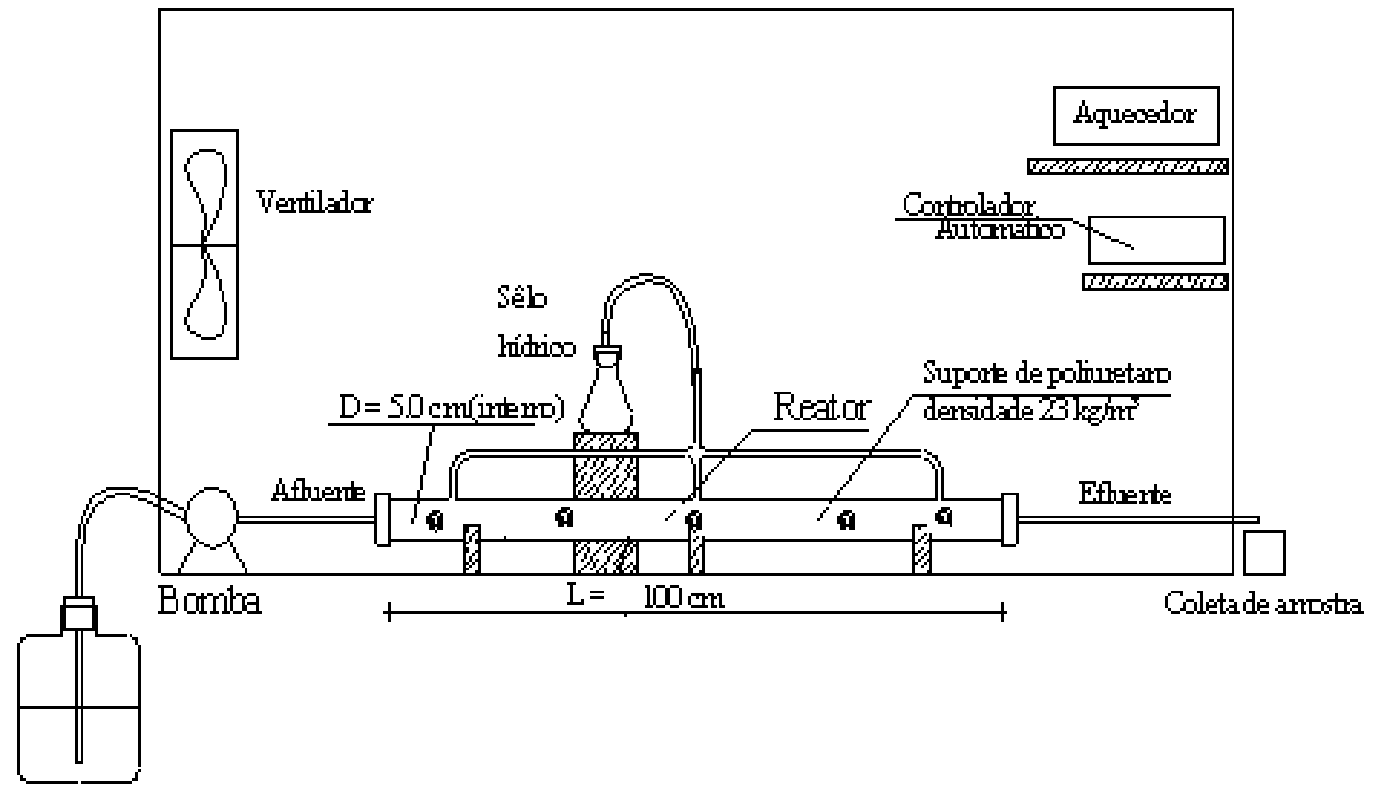

Figura 4.2. Esquema das instalações experimentais do RAHLF.

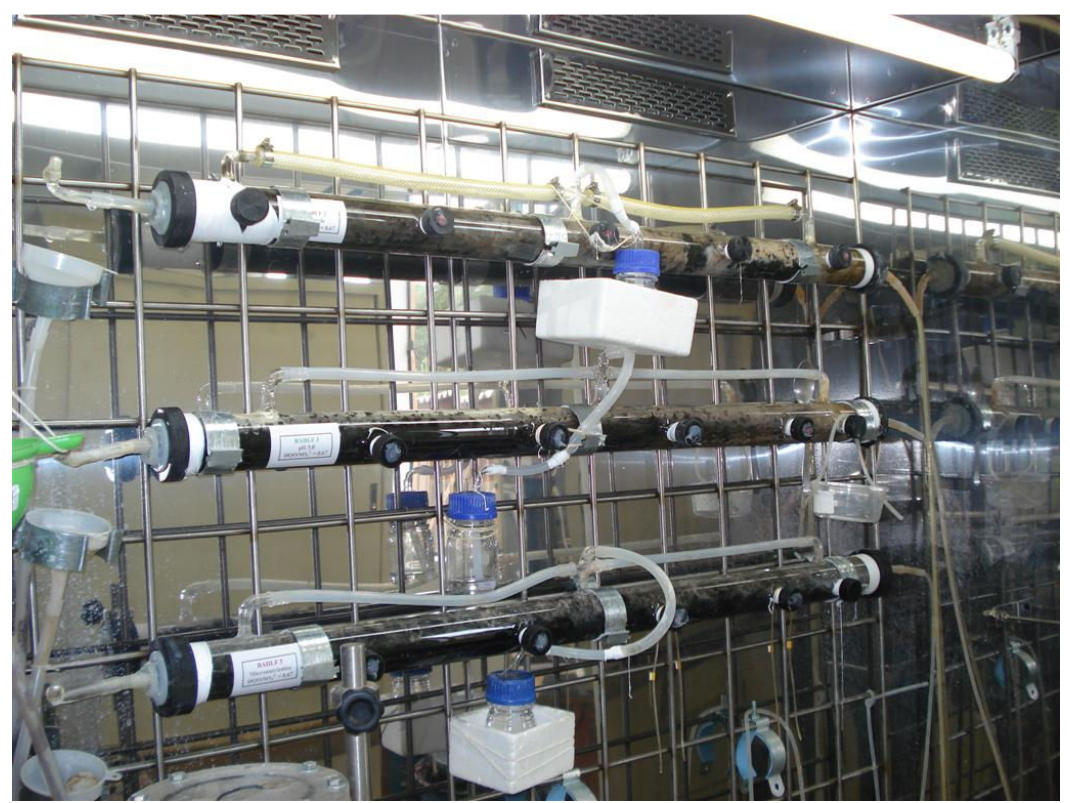

Figura 4.3. Foto dos reatores anaeróbios horizontais de leito fixo (RAHLF) em operação, instalados na câmara para controle de temperatura. 


\subsubsection{Descrição do reator $U A S B$}

O reator anaeróbio de fluxo ascendente e manta de lodo (UASB) em escala de bancada foi confeccionado em acrílico, sendo constituído de um tubo flangeado de $60 \mathrm{~cm}$ de altura e 5 cm de diâmetro externo, com três pontos de amostragem ao longo de seu comprimento em posições correspondentes a L/D (L:comprimento; D:diâmetro) de 2,4 e 7. A aproximadamente 48,5 cm da base do reator encontra-se o separador trifásico, constituído por um afunilamento para a deflexão de sólidos seguido de um dispositivo para a captação de gás. O reator possui volume útil de $840 \mathrm{ml}$ e foi confeccionado conforme o esquema apresentado na Figura 4.4.

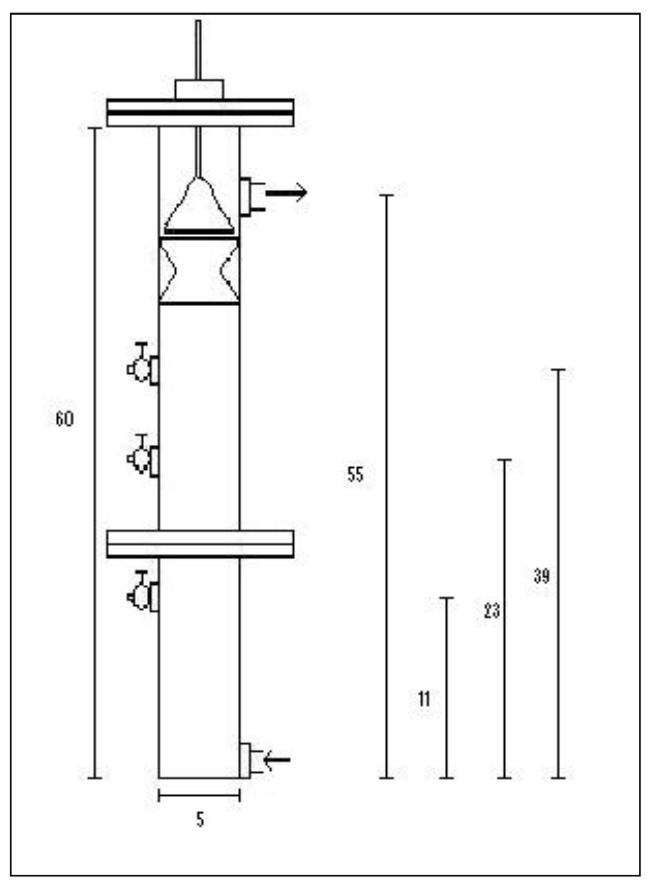

Figura 4.4. Esquema do reator UASB com as principais medidas $(\mathrm{em} \mathrm{cm})$.

Uma fotografia do reator UASB acondicionado em câmara de controle de temperatura é apresentado na Figura 4.5. 


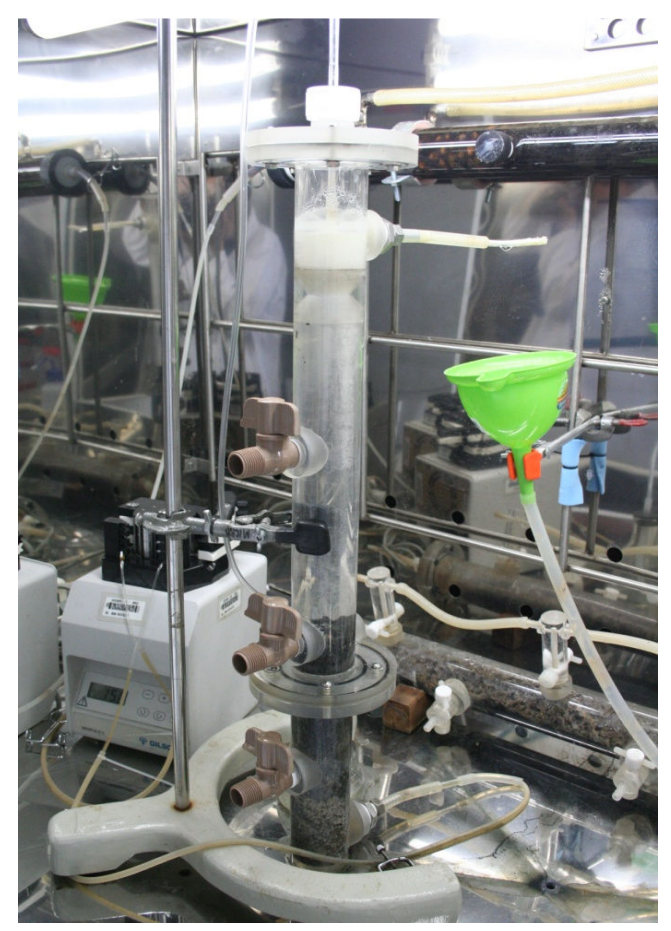

Figura 4.5. Foto do reator UASB instalado em câmara de controle de temperatura.

\subsubsection{Inóculo}

O inóculo utilizado para os ensaios com o RAHLF e o reator UASB foi lodo proveniente de reator anaeróbio de manta de lodo (UASB) aplicado ao tratamento de águas residuárias de abatedouro de aves (Avícola Dacar), localizado na cidade de Tietê, estado de São Paulo.

\subsection{4 Água residuária e fonte de carbono}

A água residuária utilizada na operação dos reatores foi a drenagem ácida de minas obtida junto à Unidade de Tratamento de Minério Osamu Utsumi da Comissão Nacional de 
Energia Nuclear em Poços de Caldas - Minas Gerais. Foram realizadas três coletas durante a operação dos reatores. Em cada visita, eram coletados cerca de 2001 de drenagem ácida em galões de 20 1. A drenagem era armazenada em temperatura ambiente, visto que essa é a condição que ela se encontra naturalmente nas lagoas de coleta. Após cada coleta, eram determinados o pH, a DQO e a concentração de sulfato.

A fonte de carbono utilizada em todos os ensaios no RAHLF e UASB foi o etanol adicionado ao reservatório de alimentação.

\subsubsection{Suporte para imobilização de lodo anaeróbio}

Como suporte de imobilização de lodo anaeróbio para o RAHLF foi utilizado espuma de poliuretano com densidade aparente de $23 \mathrm{~kg} . \mathrm{m}^{-3}$, tamanho média de poro de $543 \pm 154 \mu \mathrm{m}$ e área superficial de $43,8 \mathrm{~m}^{2} \mathrm{~g}^{-1}$. A espuma foi cortada de forma a se obter cubos (matrizes cúbicas) com $5 \mathrm{~mm}$ de aresta, aproximadamente. A relação entre a dimensão característica do recheio $(5 \mathrm{~mm})$ e o diâmetro interno do reator $(50,4 \mathrm{~mm})$ é de aproximadamente 1/10. Segundo McCabe et al. (1993), a relação máxima é de 1/8 para recheios comerciais (plásticos, cerâmicos e metais) visando a redução de caminhos preferenciais.

\subsubsection{Preparo do leito do reator anaeróbio horizontal de leito fixo (RAHLF)}

O leito do reator, com volume reacional de $1735 \mathrm{ml}$, foi preenchido com matrizes cúbicas de espuma de poliuretano contendo lodo imobilizado proveniente de reator UASB. O lodo foi imobilizado utilizando-se metodologia descrita por Zaiat et al. (1994). 
Seguindo essa metodologia, foram cortados $2000 \mathrm{ml}$ de cubos de espuma de poliuretano de $5 \mathrm{~mm}$ de aresta e colocados em um recipiente juntamente com 51 de lodo macerado, permitindo que todas as matrizes estivessem em contato com o lodo.

Decorrido o período de 24 horas de contato, as partículas cúbicas foram transferidas para o reator, resultando em porosidade de leito $(\varepsilon)$ de 0,6 ou $60 \%$ e volume líquido (volume de vazios) do reator de $1040 \mathrm{ml}$.

A porosidade foi calculada a partir da razão entre o volume de líquido drenado da zona do leito preenchida com material suporte e o volume de líquido drenado da zona do leito sem preenchimento. Procedimento similar foi realizado para cálculo do volume líquido do reator e consequentemente do tempo de detenção hidráulica (TDH) teórico. A determinação do volume líquido se deu por meio de três drenagens consecutivas do volume útil do reator já preenchido com material suporte. A partir da somatória desses volumes drenados obteve-se o volume útil do reator que foi de $1040 \mathrm{ml}$.

\subsubsection{Análises físico-químicas}

As análises de demanda química de oxigênio (DQO), sulfato, sulfeto, $\mathrm{pH}$ e metais foram realizadas seguindo os métodos descritos pelo Standard Methods for the Examination of Water and Wastewater (2005). O método para a DQO foi o 5220 D (colorimétrico de reflux fechado), para o sulfato utilizou-se o método $4500-\mathrm{SO}_{4}{ }^{2-} \mathrm{E}$ (turbidimétrico), para o sulfeto, o método $4500-\mathrm{S}^{2-} \mathrm{D}$ (azul de metileno), para o $\mathrm{pH}$, o método $4500-\mathrm{H}^{+} \mathrm{B}$ (eletrométrico) e para os metais, o método 3120 B (método ICP). Na determinação da DQO, para retirada do sulfeto que estivesse em solução, era adicionado sulfato de zinco à solução para precipitação do sulfeto presente. 
Para a determinação dos ácidos voláteis (acético, isovalérico, propiônico e isobutírico) e álcoois (acetona, etanol e n-butanol), foi empregado o cromatógrafo a gás Shimadzu ${ }^{\circledR}$ GC2010 com módulo AOC-5000 (análise de headspace), com detector de ionização de chama operado a $300^{\circ} \mathrm{C}$. A coluna utilizada será a HP-INNOWAX, a qual apresenta as seguintes características: comprimento: $30 \mathrm{~m}$; diâmetro interno: $0,25 \mathrm{~mm}$; espessura do filme: $0,25 \mu \mathrm{m}$; "phase ratio": 250. A temperatura do injetor será mantida em $250^{\circ} \mathrm{C}$. O forno será inicialmente mantido a $100^{\circ} \mathrm{C}$ por 3 min, após o que será aquecido a uma taxa de $5 \circ \mathrm{C} / \mathrm{min}$ até $180^{\circ} \mathrm{C}$ e mantido nesta temperatura por $5 \mathrm{~min}$. $\mathrm{H} 2(30 \mathrm{~mL} / \mathrm{min}), \mathrm{N} 2(33 \mathrm{~mL} / \mathrm{min})$ e ar sintético (300 mL/min) serão usados como gás de arraste/"flame", gás de "make-up" e gás de “flame”, respectivamente. A razão “split/splitness” utilizada será 1:20 (Moraes et al., 2000).

\subsubsection{Operação do reator anaeróbio horizontal de leito fixo (RAHLF)}

Foram operados três reatores com condições operacionais diferenciadas de acordo com a Tabela 4.1.

O aparato experimental, conforme Figura 4.2, para realização dos ensaios no RAHLF foi instalado no Laboratório de Processos Biológicos (EESC-USP). Os reatores foram acondicionados em câmara de inox equipada com controladores de temperatura (sistema de aquecimento e resfriamento), mantendo-se a temperatura em seu interior em $30^{\circ} \mathrm{C}$.

$\mathrm{O}$ reatores foram alimentados com a água residuária utilizando-se bomba peristáltica Gilson ${ }^{\circledR}$ e o tempo de detenção hidráulica (TDH) empregado em todos os ensaios foi de 24 horas. Todos os reatores foram alimentados com drenagem ácida e etanol foi a fonte de matéria orgânica utilizada em todos os experimentos. 
Tabela 4.1. Fases realizadas durante a operação dos reatores anaeróbios horizontais de leito fixo (RAHLF).

\begin{tabular}{|c|c|c|c|c|c|c|c|}
\hline Reator & Fases & $\begin{array}{c}\text { DQO } \\
\left(\mathrm{mg} \mathrm{l}^{-1}\right)\end{array}$ & $\begin{array}{c}\mathrm{SO}_{4}{ }^{2-} \\
\left(\mathrm{mg} \mathrm{l}^{-1}\right)\end{array}$ & $\begin{array}{c}\text { Relação } \\
\text { DQO/SO }^{2-}\end{array}$ & $\begin{array}{c}\text { Correção } \\
\text { de pH }\end{array}$ & Diluição & Recirculação \\
\hline \multirow{2}{*}{ R1 } & I & $897,3 \pm 56,3$ & $1343,5 \pm 86,4$ & 0,67 & não & não & não \\
\hline & II & $2249,6 \pm 211,5$ & $1296,0 \pm 110,6$ & 1,92 & não & não & não \\
\hline \multirow{3}{*}{ R2 } & I & $913,3 \pm 86,6$ & $1467,1 \pm 202,3$ & 0,67 & $\operatorname{sim}$ & não & não \\
\hline & II & $201,0 \pm 43,8$ & $299,3 \pm 34,6$ & 0,67 & não & $\operatorname{sim}$ & não \\
\hline & I & $227,9 \pm 66,8$ & $327,5 \pm 32,1$ & 0,67 & não & $\operatorname{sim}$ & não \\
\hline \multirow[t]{2}{*}{ R3 } & II & $299,4 \pm 14,9$ & $298,1 \pm 35,8$ & 1,0 & não & $\operatorname{sim}$ & não \\
\hline & III & $676,2 \pm 63,5$ & $732,1 \pm 205,4$ & 1,0 & não & não & $\operatorname{sim}$ \\
\hline
\end{tabular}

O reator R1 foi operado em uma condição denominada controle. A alimentação deste reator não sofreu nenhum ajuste inicial, sendo constituída de drenagem ácida real adicionada de etanol como fonte orgânica. Durante os primeiros 30 dias (partida), foram realizadas diluições progressivas na corrente afluente do reator R1 como uma tentativa de favorecer a adaptação da comunidade microbiana, já que as condições impostas pela própria característica da água residuária em estudo são bastante desfavoráveis (baixo pH e alta concentração de metais pesados). Após esse período, o sistema passou a operar com a água residuária sem diluição na relação $\mathrm{DQO} / \mathrm{SO}_{4}{ }^{2-}$ de 0,67 . A adição de etanol para que se atingisse a relação estequiométrica foi definida em função da concentração de sulfato encontrada na drenagem ácida bruta. Esta relação foi definida em função da estequiometria da reação de redução do sulfato quando se observa oxidação completa da matéria orgânica. A concentração de DQO e de sulfato na corrente afluente do reator R1, na fase I, foram de $897,3 \pm 56,3 \mathrm{mg}^{-1} \mathrm{e}$ $1343,5 \pm 86,4 \mathrm{mg} \mathrm{l}^{-1}$, respectivamente. A concentração de sulfato utilizada foi a encontrada na drenagem ácida de minas coletada e não sofria nenhum ajuste prévio.

Silva et al. (2002) avaliaram a influência da razão $\mathrm{DQO} / \mathrm{SO}_{4}{ }^{2-}$ no início da operação de reatores em batelada sobre a eficiência de remoção da matéria orgânica e redução do sulfato e os resultados indicam que essa relação exerce forte influência sobre as interações competitivas entre os microrganismos redutores de sulfato e os produtores de metano. 
Em função dos resultados obtidos, optou-se por testar o aumento na relação $\mathrm{DQO} / \mathrm{SO}_{4}{ }^{2-}$ em três vezes, para 1,92 , após 70 dias de operação, na tentativa de permitir a total redução do sulfato presente na água residuária, considerando-se que a remoção do sulfato poderia estar ocorrendo pela via dissimilatória incompleta. O aumento na relação $\mathrm{DQO} / \mathrm{SO}_{4}{ }^{2-}$ foi resultado do aumento da concentração de etanol na corrente afluente, como especificado na Tabela 4.1.

O reator R2, na fase I, foi alimentado com DAM real e utilizou a relação DQO/SO ${ }_{4}^{2-}$ estequiométrica de 0,67 , porém seu $\mathrm{pH}$ afluente era corrigido de 3,0 para 5,0 com adição de uma solução de $\mathrm{NaOH} 10 \mathrm{~N}$ durante 130 dias de operação. A relação $\mathrm{DQO} / \mathrm{SO}_{4}{ }^{2-}$ nessa fase também foi resultado da adição de etanol em função da concentração de sulfato presente na água de drenagem ácida bruta. Após a fase I, o reator foi alimentado com drenagem ácida afluente diluída com água de abastecimento para que a concentração de sulfato estivesse cerca de $300 \mathrm{mg} \mathrm{l}^{-1}$ e mantendo a mesma relação $\mathrm{DQO} / \mathrm{SO}_{4}{ }^{2-}$. A concentração de etanol na corrente afluente foi diminuída para $201,0 \pm 43,8 \mathrm{mg} \mathrm{l}^{-1}$ para que se mantivesse a relação $\mathrm{DQO} / \mathrm{SO}_{4}{ }^{2-} \mathrm{de}$ 0,67 .

No reator R3, durante a fase I, a drenagem ácida afluente também foi diluído com água de abastecimento para uma concentração de sulfato próxima a $300 \mathrm{mg} 1-1$, e a relação $\mathrm{DQO} / \mathrm{SO}_{4}{ }^{2-}$ utilizada foi 0,67 . O etanol era adicionado a corrente afluente em concentração definida pela relação $\mathrm{DQO} / \mathrm{SO}_{4}{ }^{2-}$ desejada. Após 224 dias de operação, iniciou-se a Fase II, aumentando-se a relação $\mathrm{DQO} / \mathrm{SO}_{4}{ }^{2-}$ para 1,0 através da adição de etanol em concentração mais elevada, com o objetivo de avaliar a influência de um aumento no aporte de elétrons sobre a eficiência na remoção de sulfato. A diluição na drenagem ácida foi mantida da mesma forma que vinha sendo realizada na fase I. A Fase III iniciou-se no $365^{\circ}$ dia e, a partir deste ponto, a alimentação foi substituída por drenagem bruta sem diluição, porém foi adicionado um sistema de recirculação do efluente tratado ao reator a fim de que a concentração de 
sulfato na entrada do reator ainda estivesse abaixo daquela encontrada na drenagem. A recirculação deveria funcionar como uma alternativa a questão da diluição com água de abastecimento. A relação $\mathrm{DQO} / \mathrm{SO}_{4}{ }^{2-}$ utilizada foi de 1,0 , a mesma da fase II, através da adição de etanol em concentração adequada para essa relação, como mostrado na Tabela 4.1

\subsubsection{Operação do reator anaeróbio de fluxo ascendente e manta de lodo (UASB)}

O aparato experimental, conforme mostra a Figura 4.5, foi instalado no Laboratório de Processos Biológicos (EESC-USP). O reator foi acondicionado em câmara de inox equipada com controladores de temperatura (sistema de aquecimento e resfriamento), mantendo-se a temperatura em seu interior em $30 \pm 1^{\circ} \mathrm{C}$.

O reator foi alimentado com a água residuária utilizando-se bomba peristáltica Gilson ${ }^{\circledR}$ e o tempo de detenção hidráulica (TDH) empregado nos ensaios foi de 24 horas, calculado a partir do volume útil teórico do reator.

A operação do reator ocorreu em três etapas distintas, como descrito na Tabela 4.2.

Tabela 4.2. Etapas realizadas durante a operação do reator UASB.

\begin{tabular}{|c|c|c|c|c|c|c|c|}
\hline Etapa & Fase & $\begin{array}{c}\text { DQO } \\
\left(\mathrm{mg} \mathrm{l}^{-1}\right)\end{array}$ & $\begin{array}{c}\mathrm{SO}_{4}{ }^{2-} \\
\left(\mathrm{mg} \mathrm{l}^{-1}\right)\end{array}$ & $\begin{array}{c}\text { Relação } \\
\mathrm{DQO} / \mathrm{SO}_{4}{ }^{2-}\end{array}$ & $\begin{array}{c}\text { Volume } \\
\text { de lodo } \\
\text { (ml) }\end{array}$ & Diluição & Recirculação \\
\hline \multirow{3}{*}{ A } & I & $872,8 \pm 52,3$ & $1399,2 \pm 58,1$ & 0,67 & 156 & não & não \\
\hline & II & $1009,2 \pm 52,2$ & $1610,1 \pm 250,8$ & 0,67 & 312 & não & não \\
\hline & III & $854,0 \pm 124,2$ & $1315,5 \pm 310,1$ & 0,67 & 468 & não & não \\
\hline \multirow{4}{*}{ B } & I & $225,3 \pm 35,7$ & $314,7 \pm 42,2$ & 0,67 & 468 & $\operatorname{sim}$ & não \\
\hline & II & $399,3 \pm 92,2$ & $409,3 \pm 171,3$ & 1,0 & 468 & $\operatorname{sim}$ & não \\
\hline & III & $962,7 \pm 42,3$ & $1062,5 \pm 68,4$ & 1,0 & 468 & $\operatorname{sim}$ & não \\
\hline & IV & $1133,3 \pm 57,1$ & $1259,7 \pm 44,6$ & 1,0 & 468 & não & $\operatorname{sim}$ \\
\hline
\end{tabular}


Na etapa A, analisou-se a influência da concentração de inóculo, com o volume da manta de lodo variando de 156 a $468 \mathrm{ml}$. A quantidade inicial de volume de lodo (156 ml) inoculada foi definida impondo-se ao UASB a mesma carga orgânica mássica que foi utilizada nos reatores RAHLF operados nesse projeto. Segundo esse critério, dos $840 \mathrm{ml}$ de volume útil do reator, $156 \mathrm{ml}$ seriam ocupados pelo lodo granular. Considerando que este lodo apresentava 32,85 $\mathrm{g} \mathrm{SVT}^{-1}$, o volume de inóculo utilizado propiciou uma concentração celular de 7,49 $\mathrm{g} \mathrm{SVT}^{-1}$. Os volumes de lodo das fases II e III da etapa A foram definidos como o dobro e o triplo do volume da fase I, respectivamente, e foram utilizados em função dos resultados pouco satisfatórios da fase I. A matéria orgânica foi adicionada em quantidade que mantivesse a relação entre as concentrações de DQO e sulfato em 0,67 . O reator foi alimentado com drenagem bruta, sem tratamento prévio algum, nas concentrações de sulfato encontradas na água residuária.

Após a primeira etapa de operação, que analisou o comportamento do reator anaeróbio no tratamento da drenagem ácida de minas frente à variação da quantidade de inóculo, optouse por iniciar uma nova etapa experimental (etapa B), na qual o reator foi alimentado com drenagem ácida diluída com uma concentração de sulfato de cerca de $350 \mathrm{mg} \mathrm{l}^{-1}$ e volume fixo de lodo $(468 \mathrm{ml})$. A influência da relação $\mathrm{DQO} / \mathrm{SO}_{4}{ }^{2-}$ e da diluição do afluente foi analisada (fases I e II). Na fase I, etanol foi adicionado a corrente afluente em concentração que mantivesse a relação $\mathrm{DQO} / \mathrm{SO}_{4}{ }^{2-}$ em 0,67 . Após 90 dias de operação, a relação $\mathrm{DQO} /$ $\mathrm{SO}_{4}{ }^{2-}$ foi aumentada para 1,0 com o aumento da concentração de etanol no afluente. Na fase III, o volume de lodo e a relação $\mathrm{DQO} / \mathrm{SO}_{4}{ }^{2-}$ foram fixados em $468 \mathrm{ml}$ e 1,0, respectivamente, e a variável analisada foi a diluição através de um sistema de bombeamento de água na entrada do reator. O afluente passou a ser constituído de drenagem bruta e a vazão de alimentação de água foi estabelecida de forma que a concentração de sulfato estivesse diluída na entrada do reator e no mesmo valor utilizado nas fases I e II. O objetivo dessa fase era 
analisar a influência do regime de escoamento sobre o reator, visto que a água de abastecimento foi adicionada ao reator em uma vazão que simulasse uma corrente de recirculação do reator. Na fase IV, o sistema de recirculação foi iniciado com recirculação do efluente tratado, também com o mesmo objetivo de promover a diluição da drenagem bruta afluente. A relação DQO/ $\mathrm{SO}_{4}{ }^{2-}$ foi mantida em 1,0 e o etanol foi adicionado em concentração adequada a manutenção dessa relação.

4.2.10 Monitoramento do reator anaeróbio horizontal de leito fixo (RAHLF) e do reator anaeróbio de fluxo ascendente (UASB)

O monitoramento do RAHLF e do reator UASB foi realizado por meio de coleta e análise de amostras do afluente e efluente. As análises de afluente e efluente com relação à demanda química de oxigênio (DQO), sulfato, sulfeto, $\mathrm{pH}$ e ácidos voláteis totais foram realizadas com a frequência apresentada na Tabela 4.3. A temperatura da câmara foi monitorada com termômetro digital acoplado aos controladores de temperatura e as vazões aplicadas ao reator por medida em proveta de $100 \mathrm{ml}$. A frequência dessas análises também está apresentada na Tabela 4.3.

Tabela 4.3. Parâmetros de monitoramento e frequência das análises.

\begin{tabular}{cc}
\hline ANÁLISES & FREQUÊNCIA \\
\hline Vazão & Diária \\
Temperatura & Diária \\
DQO & 2 xemana \\
Ácidos voláteis totais & $2 x$ semana \\
pH & $2 x$ semana \\
Sulfato & $2 x$ semana \\
Sulfeto & $2 x$ semana \\
\hline
\end{tabular}




\subsubsection{Estudos hidrodinâmicos}

Foram realizados ensaios hidrodinâmicos no reator anaeróbio horizontal de leito fixo (RAHLF) e no reator anaeróbio de fluxo ascendente (UASB) antes do início da operação dos mesmos. Todos os ensaios hidrodinâmicos tiveram a finalidade de avaliar algumas características associadas ao padrão de escoamento, tais como caminhos preferenciais, regiões de estagnação e o tempo de detenção hidráulica real aplicado ao sistema. O tempo de detenção hidráulica teórico empregado foi de 24 horas. O traçador utilizado foi o cloreto de sódio $(\mathrm{NaCl})$ e aplicado aos reatores na forma de estímulo degrau (Levenspiel, 2000).

A metodologia aplicada consistiu em instalar, na saída do efluente líquido do reator, um vertedor com uma sonda para detecção de condutividade, acoplada a um transdutor CBL da Texas Instruments ${ }^{\circledR}$, que por sua vez foi acoplado a uma calculadora Texas TI-89. Os sinais foram interpretados pela calculadora por aproximadamente 72 horas após a perturbação no ensaio com TDH teórico de 24 horas.

Os dados obtidos com a calculadora foram ajustados com o auxílio do software Microcal Origin $6.0^{\circledR}$ para determinação das curvas de distribuição do tempo de detenção hidráulica, cálculo do tempo de detenção hidráulica real e ajuste dos modelos de escoamento.

\subsection{Análises de Biologia Molecular}

A avaliação da diversidade da comunidade microbiana foi realizada a partir de fragmentos do gene RNAr 16S, por meio das técnicas de reação em cadeia da polimerase (PCR), clonagem, sequenciamento e análises filogenéticas. O DNA foi extraído segundo o 
protocolo de Melvin e Hobson (1994). A amplificação dos fragmentos de DNA por PCR empregou primers específicos para o Domínio Bactéria e Archaea (Tabela 4.4).

Tabela 4.4. Primers empregados nas reações de PCR.

\begin{tabular}{|c|c|c|}
\hline PRIMER & $\begin{array}{l}\text { PROGRAMA DE } \\
\text { CICLOS DO } \\
\text { TERMOCICLADOR }\end{array}$ & REFERÊNCIA \\
\hline $\begin{array}{l}\text { M13 F: 5' - gta aaa cga cgg ccag-3' } \\
\text { M13 R: 5' - cag gaa aca gct atg ac - 3' }\end{array}$ & $\begin{array}{c}94^{\circ} \mathrm{C}-5 \mathrm{~min} \\
\left(94^{\circ} \mathrm{C}-1 \mathrm{~min} ; 55^{\circ} \mathrm{C}-1 \mathrm{~min}\right. \\
\left.72^{\circ} \mathrm{C}-1 \mathrm{~min}\right) \times 25 \text { ciclos } \\
72^{\circ} \mathrm{C}-7 \mathrm{~min} \\
4^{\circ} \mathrm{C}-\infty\end{array}$ & Messing, 1983 \\
\hline $\begin{array}{c}\text { Dominio Bacteria } \\
\text { 27 F: 5'- aga gtt tga tcm tgg ctc ag }-3 \\
1100 \text { R: } \text { 5' }^{\prime}-\text { ggg ttg cgc tcg ttg }-3\end{array}$ & $\begin{array}{c}94^{\circ} \mathrm{C}-2 \mathrm{~min} \\
\left(94^{\circ} \mathrm{C}-1 \mathrm{~min} ; 69^{\circ} \mathrm{C}-30 \mathrm{~s} ; 72^{\circ} \mathrm{C}\right. \\
-3 \mathrm{~min}) \times 15 \text { ciclos } \\
\left(94^{\circ} \mathrm{C}-1 \mathrm{~min} ; 63^{\circ} \mathrm{C}-30 \mathrm{~s} ; 72^{\circ} \mathrm{C}\right. \\
-3 \min ) \times 20 \text { ciclos } \\
4^{\circ} \mathrm{C}-\infty\end{array}$ & Lane,1991 \\
\hline $\begin{array}{c}\text { Dominio Archaea } \\
109 \text { F: 5' - ack get cag taa cac gt - 3' } \\
934 \text { R: 5' - gtg ctc ccc cgc caa ttc ct }-3 \text {, }\end{array}$ & $\begin{array}{c}94^{\circ} \mathrm{C}-5 \mathrm{~min} \\
\left(94^{\circ} \mathrm{C}-45 \mathrm{~s} ; 60^{\circ} \mathrm{C}-45 \mathrm{~s} ; 72^{\circ} \mathrm{C}\right. \\
-45 \mathrm{~s}) \times 38 \text { ciclos } \\
72^{\circ} \mathrm{C}-5 \min \\
4^{\circ} \mathrm{C}-\infty \\
\end{array}$ & $\begin{array}{c}\text { Grosskopf et } \\
\text { al., } 1998\end{array}$ \\
\hline
\end{tabular}

A clonagem foi feita com pGEM Easy Vector System I, de acordo com as especificações do fabricante. Os clones cresceram em meio LB e foram submetidos à PCR com primers M13. Os produtos de PCR foram purificados com kit Illustra GFX (GE Healthcare) e sequenciados em sequenciador automático 310 ABI Prism (Applied Biosystem). As sequências obtidas foram editadas no programa DNAstar (Lasergene Sequence Analysis), alinhadas com microrganismos da base de dados do Greengenes (http://greengenes.lbl.gov/cgi-bin/nph-NAST_align.cgi) e analisadas filogeneticamente no sofware ARB (Ludwig et al., 2004). 
Para definição das unidades taxonômicas operacionais (UTOs) foi usado o programa DOTUR (Schloss e Handelsman, 2005). Para tanto, utilizou-se uma matriz de distância evolutiva calculada por meio do programa DNADIST (algoritmo do Kimura) do pacote PHYLIP 3.63 (FELSENSTEIN: http://evolution.genetics. washington.edu/phylip.html), a partir do alinhamento feito usando-se o programa Clustal X 2.0, com definições de parâmetros padrão. Os números de UTOs e de sequências de cada UTO foram determinados considerando-se a distância evolutiva de 0,02. 


\section{CAPÍTULO 5}

\section{RESULTADOS E DISCUSSÃO}

\subsection{Ensaios de Imobilização da Biomassa em Espuma de Poliuretano}

Os ensaios de imobilização da biomassa avaliaram a influência do tipo de fonte de carbono e do inóculo sobre as eficiências na remoção de DQO e sulfato e, principalmente, sobre a quantidade de biomassa aderida ao material suporte. Para todos os substratos utilizados (ácido fórmico, etanol ou ácido lático), a remoção de DQO variou entre 10 e 30\% ao longo dos 28 dias de ensaio, enquanto a concentração de sulfato e o pH mantiveram-se estáveis (1200 $\mathrm{mg} \mathrm{l}^{-1}$ de sulfato e $\mathrm{pH} \mathrm{3,0).} \mathrm{Esses} \mathrm{resultados} \mathrm{eram} \mathrm{os} \mathrm{esperados} \mathrm{visto} \mathrm{que,} \mathrm{em}$ função do pequeno volume do reator diferencial (um elemento infinitesimal de um reator integral), o tempo de detenção hidráulica é muito baixo, resultando em baixa ou nenhuma remoção detectável.

\subsubsection{Variação temporal da biomassa aderida ao suporte}

As análises de sólidos totais voláteis, aderidos ao material suporte, realizadas ao final de cada semana do experimento mostraram curvas com dois tipos de comportamento específico (Figura 5.1). Para os ensaios realizados com etanol e inóculo de sedimento de mina, a curva de STV em função do tempo aproximou-se de uma sigmóide clássica de Boltzman, o mesmo observado para os ensaios que utilizaram ácido fórmico como fonte de 
carbono, independente do tipo de inóculo utilizado. Para as outras condições estudadas, etanol e inóculo de abatedouro ou ácido lático para os dois tipos de inóculo, as curvas de STV em função do tempo permitiram o ajuste de uma curva com comportamento hiperbólico.

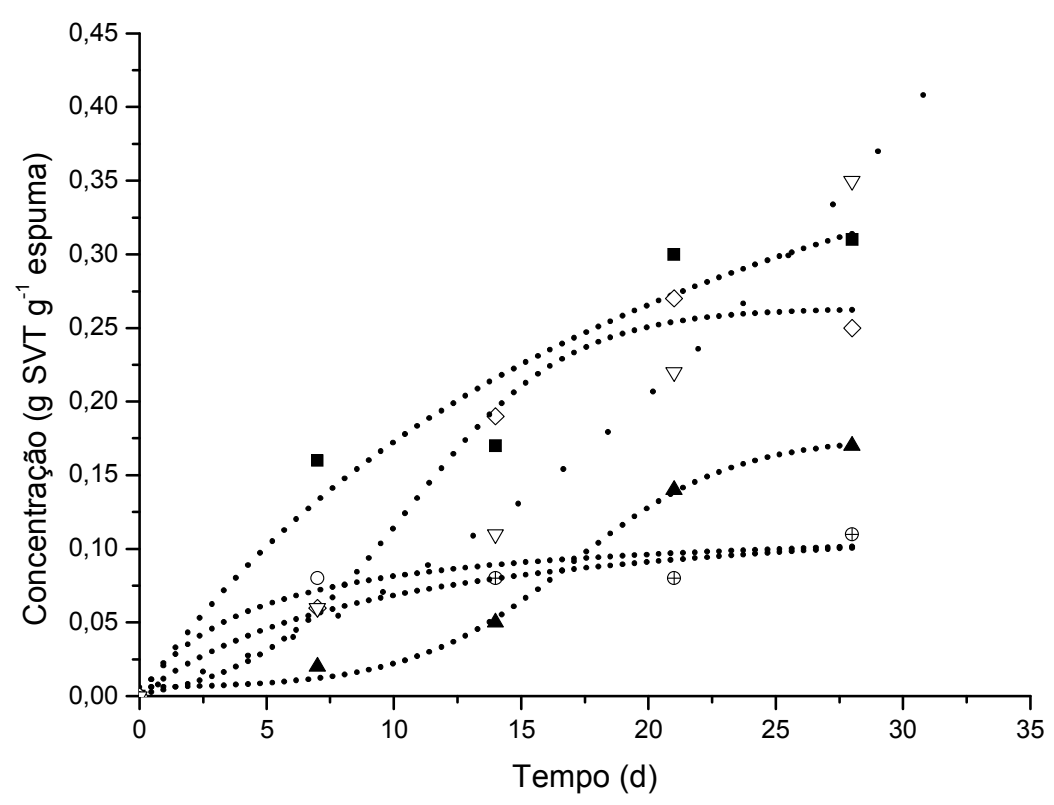

Figura 5.1. Crescimento da biomassa em sólidos totais voláteis $(\mathrm{g})$ por massa $(\mathrm{g})$ de material suporte ( $\boldsymbol{\nabla}$ : ácido fórmico e AI; $\diamond$ : ácido fórmico e SI; $\mathbf{m}$ : etanol e AI, $\boldsymbol{\Delta}$ : etanol e SI, ○: ácido lático e $\mathrm{AI}$; +: ácido lático e SI). AI: inóculo anaeróbio de abatedouro e SI: inóculo do sedimento de mina.

O ajuste da expressão sigmóide pode indicar a necessidade de pré-adaptação dos organismos ao meio enquanto que o ajuste hiperbólico indicaria que os organismos já estariam de alguma forma adaptados àquele meio específico, o que poderia facilitar a aderência ao material suporte. Ácido lático e etanol são intermediários comuns na digestão anaeróbia sendo, portanto, natural o comportamento hiperbólico observado nos experimentos com esses substratos e lodo anaeróbio como inóculo. Embora o ácido fórmico tenha apenas um carbono, o comportamento em forma de sigmóide observado para os experimentos 
realizados com esse substrato com lodo anaeróbio como inóculo pode ser explicado pelo mesmo não ser um intermediário tão frequente em digestores anaeróbios. No caso do sedimento de mina, de acordo com esse raciocínio, o esperado seria que a sigmóide representasse melhor o comportamento dos ensaios com esse inóculo independente da fonte de carbono utilizada. Por ser obtido de ambiente com baixa ou nenhuma concentração de compostos orgânicos, o sedimento não deveria ter biota adaptada a nenhum dos substratos utilizados. No entanto, o comportamento hiperbólico observado para o ensaio com ácido lático e sedimento de mina não pode ser analisado somente em função da diversidade do inóculo visto que seu comportamento foi similar ao inóculo de abatedouro de aves, que possui uma flora microbiana mais favorável ao crescimento nas condições estudadas.

Uma hipótese que poderia explicar o comportamento diferenciado observado na presença de ácido lático é a termodinâmica da reação de oxidação do lactato a ácido acético. O ácido acético é um intermediário comum na bioquímica anaeróbia e sua formação a partir do lactato possui uma energia livre de Gibbs bastante favorável (equação 5.1) quando comparada a oxidação dos outros substratos estudados, etanol e ácido fórmico (equações 5.2 e 5.3, respectivamente). A oxidação completa do etanol a gás carbônico e água é a reação mais favorável quando comparada às outras (equação 5.4), porém essa conversão é dependente de um grupo bastante específico de bactérias redutoras de sulfato (Muyzer e Stams, 2008) que, provavelmente, não seriam capazes de se estabelecer nas condições ambientais extremas dos sistemas estudados. Dessa forma, a oxidação incompleta do ácido lático seria a reação mais favorável dentre os sistemas analisados.

$0.5 \mathrm{SO}_{4}^{2-}+\mathrm{CH}_{3} \mathrm{CHOHCOO}^{-} \rightarrow \mathrm{CH}_{3} \mathrm{COO}^{-}+0.5 \mathrm{H}_{2} \mathrm{~S}+\mathrm{HCO}_{3}^{-}$

$\Delta \mathrm{G}^{\mathrm{o}}=-80.2 \mathrm{~kJ} / \mathrm{mol}$ lactato 
$0.5 \mathrm{SO}_{4}{ }^{2-}+\mathrm{CH}_{3} \mathrm{CH}_{2} \mathrm{OH} \rightarrow \mathrm{CH}_{3} \mathrm{COO}^{-}+0.5 \mathrm{H}_{2} \mathrm{~S}+\mathrm{H}_{2} \mathrm{O}$

$\Delta \mathrm{G}^{\mathrm{o}}=-69.2 \mathrm{~kJ} / \mathrm{mol}$ etanol

$0.25 \mathrm{SO}_{4}{ }^{2-}+\mathrm{HCOO}^{-}+0.5 \mathrm{H}^{+} \rightarrow \mathrm{HCO}_{3}^{-}+0.25 \mathrm{H}_{2} \mathrm{~S}$

$\Delta \mathrm{G}^{\mathrm{o}}=-58.04 \mathrm{~kJ} / \mathrm{mol}$ formato

$1.5 \mathrm{SO}_{4}{ }^{2-}+\mathrm{CH}_{3} \mathrm{CH}_{2} \mathrm{OH}+\mathrm{H}^{+} \rightarrow 2 \mathrm{HCO}_{3}{ }^{-}+1.5 \mathrm{H}_{2} \mathrm{~S}+\mathrm{H}_{2} \mathrm{O}$

$\Delta \mathrm{G}^{\mathrm{o}}=-162.28 \mathrm{~kJ} / \mathrm{mol}$ etanol

Os valores de $\Delta \mathrm{G}^{\mathrm{o}}$ das equações 5.1 a 5.4 foram calculadas através da energia padrão livre de formação de cada componente de acordo com Sawyer et al. (2005).

\subsubsection{Quantidade máxima de biomassa aderida ao suporte}

A Tabela 5.1 apresenta as concentrações de STV máximas atingidas para cada condição testada e o tempo necessário para que os sistemas atingissem essa concentração. Pode-se observar grande influência do tipo de inóculo sobre a concentração máxima de biomassa aderida nas partículas de espuma de poliuretano e no tempo necessário para se atingir essa concentração quando ácido fórmico e etanol foram utilizados como fonte de carbono. Nenhuma influência do inóculo, entretanto, foi observada quando ácido lático foi utilizado. 
Tabela 5.1. Concentrações máximas de STV para cada condição analisada.

\begin{tabular}{|c|c|c|c|}
\hline \multicolumn{2}{|c|}{ Condição } & \multirow{2}{*}{$\begin{array}{c}\text { Concentração } \\
\text { máxima de STV } \\
\text { (g STV g } \text { g espuma) }^{-1}\end{array}$} & \multirow{2}{*}{$\begin{array}{l}\text { Tempo necessário para } \\
\text { atingir concentração } \\
\text { máxima (dias) }\end{array}$} \\
\hline $\begin{array}{l}\text { Fonte de } \\
\text { carbono }\end{array}$ & Inóculo & & \\
\hline Ácido fórmico & AI & $0,35 \pm 0,1$ & $28 *$ \\
\hline Ácido fórmico & SI & $0,27 \pm 0,1$ & 21 \\
\hline Etanol & AI & $0,30 \pm 0,1$ & 28 \\
\hline Etanol & SI & $0,16 \pm 0,1$ & 21 \\
\hline Ácido lático & AI & $0,10 \pm 0,2$ & 7 \\
\hline Ácido lático & SI & $0,10 \pm 0,2$ & 7 \\
\hline
\end{tabular}

*A concentração máxima refere-se ao valor máximo encontrado no período de experimento, não representando a concentração máxima que poderia ser obtida.

$\mathrm{Na}$ etapa em que os reatores foram alimentados com etanol, o inóculo proveniente de reator tratando resíduo de abatedouro de aves atingiu um valor máximo $\left(\mathrm{C}_{\mathrm{max}}\right)$ de biomassa aderida $87,5 \%$ superior àquele obtido nos reatores com inóculo proveniente do sedimento da mina. Quando se utilizou ácido fórmico como doador de elétrons, nota-se que a concentração máxima de STV obtida com a utilização de inóculo de reator anaeróbio foi cerca de $30 \%$ superior ao observado quando se utilizou inóculo proveniente de sedimento de mina. Nos dois casos, os tempos para se atingir as máximas concentrações $\left(t_{\max }\right)$ foram iguais, 28 dias para lodo anaeróbio e 21 dias para sedimento de mina. No entanto, é importante ressaltar que no caso do uso de ácido fórmico e lodo anaeróbio, a curva obtida indica que esta ainda não era a concentração máxima que poderia ser observada, porém, como os ensaios tinham uma duração determinada (28 dias) não foi possível determinar a concentração máxima para esta combinação de inóculo e fonte de carbono.

As diferenças observadas nos valores de $C_{\max }$ e $t_{\max }$ podem ser avaliadas em função das características destes dois inóculos. O inóculo do reator anaeróbio é proveniente de um sistema com longo tempo de operação e apresenta grânulos com grande diversidade microbiana (Hirasawa et al., 2008), resultando em maior capacidade de adaptação às condições impostas ( $\mathrm{pH}$ baixo e presença de metais pesados). O inóculo obtido na mina é 
proveniente do sedimento que margeia as lagoas de depósito de drenagem ácida, um ambiente bastante desfavorável à diversidade microbiana, em função do baixo pH (próximo a 3) e concentração de metais pesados.

Quando se utilizou ácido lático como fonte de carbono, os resultados não revelam diferença entre os tipos de inóculo utilizados $\left(0,10 \mathrm{~g} \mathrm{STV}^{-1}\right.$ espuma). Nesse caso, o inóculo pareceu não exercer influência sobre a capacidade de crescimento microbiano. As concentrações de STV não se alteraram de maneira significativa após 7 dias de experimento quando ácido lático foi utilizado, o que também confirma a dificuldade do biofilme se desenvolver nestas condições, visto que os valores obtidos foram inferiores à metade daquele obtido no ensaio com etanol ou ácido fórmico e inóculo de abatedouro de aves.

A fonte de carbono também influenciou a máxima concentração de biomassa aderida ao material suporte. Os valores obtidos quando o ácido fórmico foi utilizado foram os maiores, seguidos pelos valores obtidos com a utilização de etanol. Os menores valores de máxima concentração de biomassa aderida foram obtidos nos reatores alimentados com ácido lático. Essa diferença na formação do biofilme observada quando foram usados diferentes substratos parece estar relacionada diretamente a facilidade de utilização da fonte de carbono, visto que as maiores concentrações de STV estiveram inversamente relacionadas ao número de carbonos de cada substrato utilizado. No caso do ácido fórmico, por conter apenas um carbono, seria mais prontamente oxidado, enquanto que para o etanol e ácido lático, por conter dois e três carbonos, respectivamente, etapas anteriores de oxidação seriam necessárias e, dessa forma, podem ter dificultado o crescimento do biofilme no material suporte.

Uma análise geral dos dados apresentados na Tabela 5.1 indica que a combinação de uma fonte de matéria orgânica com menor número de carbono e um inóculo com alta diversidade microbiana leva a maiores valores de massa de microrganismos aderidos ao 
material suporte. Essa alta concentração é de extrema importância para operação estável de reatores anaeróbios, com relação inversa entre essa concentração e o tempo de detenção hidráulica a ser aplicado no reator. No entanto, o tempo para se atingir a máxima concentração, que pode ser relacionado com a partida do reator, parece não apresentar relação direta com natureza do inóculo e com a fonte de carbono utilizada.

A facilidade de oxidação do lactato parece ter contribuído para uma rápida partida no crescimento microbiano, observado nos primeiros 7 dias. Esse crescimento foi inferior apenas ao sistema que utilizou ácido fórmico e inóculo do abatedouro de aves. Entretanto, apenas a termodinâmica favorecida da reação do lactato não foi suficiente para favorecer o melhor crescimento e aderência dos microorganismos ao final dos experimentos. Outra consideração que poderia indicar os menores resultados de crescimento com lactato seriam os coeficientes de difusão dos substratos estudados em água (Tabela 5.2). Em reatores de leito fixo com baixas velocidades superficiais, a resistência a transferência de massa sólido-líquida pode influenciar de maneira significativa as velocidades de degradação do substrato e, consequentemente, a dinâmica de aderência da biomassa ao material suporte (Zaiat et al., 2000).

Tabela 5.2. Coeficientes de difusão em água dos substratos analisados.

\begin{tabular}{cc}
\hline Substrato & Coeficiente de difusão $\left(\mathbf{c m}^{2} \mathbf{~ s}^{-1}\right)$ em água \\
\hline Ácido fórmico $^{1}$ & $1,35.10^{-5}$ \\
Etanol $^{1}$ & $1,28.10^{-5}$ \\
Ácido lático $^{2}$ & $0,996.10^{-5}$ \\
\hline
\end{tabular}

1- Perry e Chilton, 1985.

2- Arnaud et al., 1994.

Ribeiro et al. (2005) relatam em ensaio semelhante com diferentes fontes de substrato a grande influência da fonte de carbono sobre o processo de adesão microbiana na matriz de 
espuma de poliuretano. Silva et al. (2006), que utilizaram como inóculo o mesmo lodo proveniente de reator UASB tratando resíduo de abatedouro de aves e o mesmo sistema de reatores diferenciais, obtiveram concentrações máximas próximas a $0,9 \mathrm{~g} \mathrm{STV} \mathrm{g}^{-1}$ espuma, porém utilizando fontes de carbono mais complexas (glicose, extrato de carne, amido e óleo de soja) e pH neutro em sistemas fechados com recirculação da corrente afluente.

\subsubsection{Velocidades de colonização}

Para melhor avaliação da dinâmica de aderência, foram calculadas as velocidades máximas e médias de colonização em função do tempo para cada situação analisada. A Figura 5.2 apresenta a variação das velocidades de colonização em função do tempo, calculadas a partir dos dados apresentados na Figura 5.1, por meio da equação 4.1, e a Tabela 5.3 apresenta as velocidades máximas e médias de colonização, calculadas pelas equações 4.2 e 4.3, respectivamente.

A velocidade média de colonização obtida em cada ensaio também se relacionou de maneira inversa à quantidade de carbonos do substrato utilizado (Tabela 5.3) da mesma forma que o observado para a quantidade máxima de biomassa aderida. As menores velocidades médias foram obtidas quando o ácido lático foi utilizado como fonte de carbono e as maiores foram obtidas com ácido fórmico. Valores intermediários foram obtidos para o etanol. 


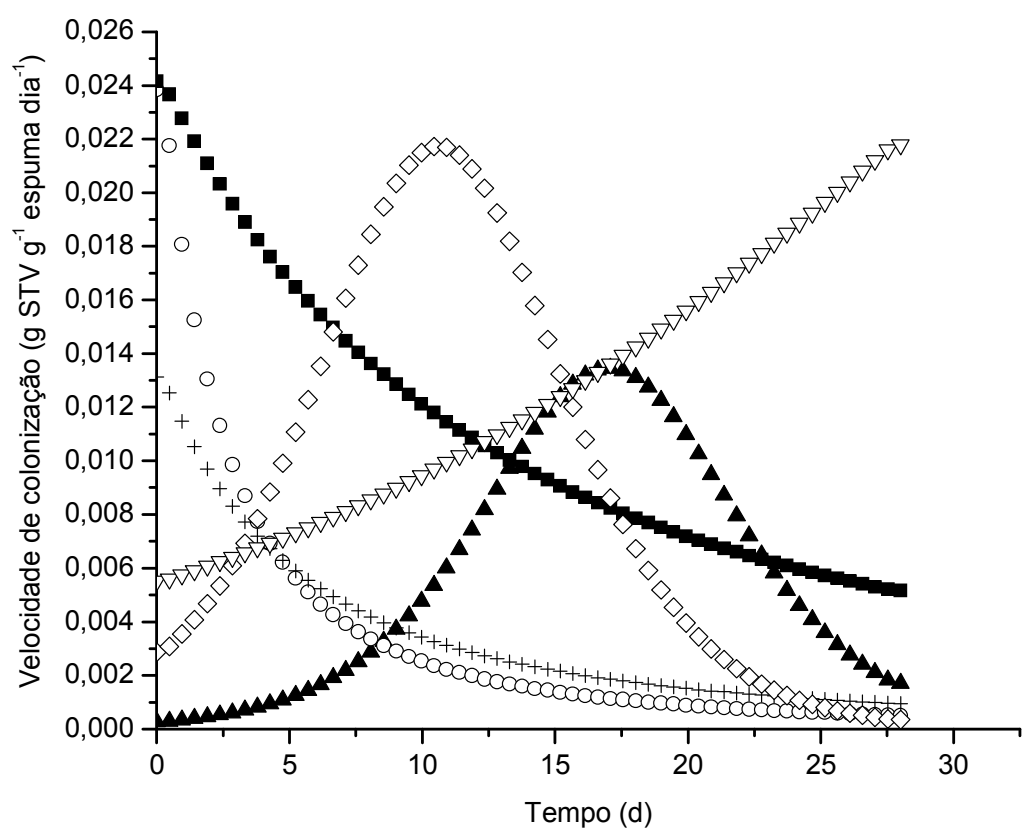

Figura 5.2. Velocidades de colonização em função do tempo no material suporte ( $\boldsymbol{\nabla}$ : ácido

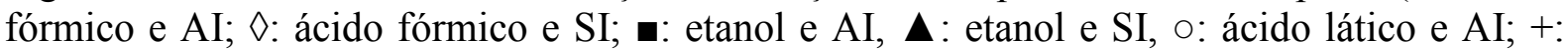
ácido lático e SI). AI: inóculo anaeróbio de abatedouro e SI: inóculo de sedimento de mina.

Tabela 5.3. Velocidades máximas $\left(\mathrm{v}_{\max }\right)$ e médias $\left(\mathrm{v}_{\mathrm{med}}\right)$ de colonização para cada condição empregada (AI: inóculo de abatedouro, SI: inóculo do sedimento de mina).

\begin{tabular}{|c|c|c|c|}
\hline \multicolumn{2}{|c|}{ Condição } & \multirow{2}{*}{$\begin{array}{c}v_{\max } \\
\left(\mathrm{g} \mathrm{STV}^{-1} \text { espuma }\right. \\
\left.\text { dia }^{-1}\right)\end{array}$} & \multirow{2}{*}{$\left(\begin{array}{c}V_{\text {med }} \\
\left.\text { dia }^{-1}\right)\end{array}\right.$} \\
\hline $\begin{array}{l}\text { Fonte de } \\
\text { carbono }\end{array}$ & Inóculo & & \\
\hline Ácido fórmico & $\mathrm{AI}$ & 0,022 & 0,012 \\
\hline Ácido fórmico & SI & 0,022 & 0,009 \\
\hline Etanol & AI & 0,024 & 0,011 \\
\hline Etanol & SI & 0,013 & 0,006 \\
\hline Ácido lático & AI & 0,024 & 0,004 \\
\hline Ácido lático & SI & 0,013 & 0,004 \\
\hline
\end{tabular}

A origem do inóculo também afetou as velocidades médias de colonização quando ácido fórmico e etanol foram usados como fonte de carbono. No entanto, as velocidades médias de colonização não foram afetadas pela origem do inóculo nos experimentos realizados com ácido lático. Sendo o lodo de abatedouro de aves um inóculo com maior facilidade de crescimento, a fonte de carbono sendo de 1 ou 2 carbonos parece ser suficiente 
para favorecer um grande desenvolvimento ao longo da operação do sistema. Comportamento semelhante ocorreu com o inóculo de sedimento de mina, porém a diferença entre os valores de velocidade média para as fontes de carbono utilizadas foi maior neste caso. A presença do sedimento de mina como inóculo parece dificultar o crescimento microbiano, sendo necessária uma fonte de carbono muito facilmente utilizada (contendo um carbono apenas) para favorecer seu desenvolvimento diferentemente do inóculo de lodo de abatedouro.

O comportamento observado para as velocidades médias de colonização do material suporte está de acordo com os resultados de quantidade de biomassa aderida ao suporte, pois maiores velocidades médias de colonização resultarão efetivamente em maiores quantidades de células aderidas ao suporte.

A velocidade máxima de colonização do material suporte está relacionada com a partida de um sistema e é um parâmetro mais acurado para essa análise que o tempo necessário para se atingir a concentração máxima de biomassa aderida. A velocidade máxima foi fortemente influenciada pela origem do inóculo quando etanol e ácido lático são utilizados como fonte de carbono. No entanto, a velocidade máxima não se alterou com a mudança do inóculo quando ácido fórmico foi utilizado como fonte de carbono. Esse comportamento sugere que nesse caso, a simplicidade da molécula (com apenas 1 carbono) resultará em rápida partida do sistema independente da origem do inóculo.

A utilização do inóculo de lodo de reator anaeróbio permitiu a obtenção de velocidades máximas de crescimento muito semelhantes com o uso das três fontes de carbono, representando a fonte de carbono pouca influência sobre os valores encontrados. Isso reforça que a escolha de um inóculo com grande diversidade de microrganismos é bastante favorável para a partida de reatores, visto que o inóculo parece ser capaz de rapidamente iniciar a colonização do material suporte. Entretanto, quando se relacionam essas velocidades 
máximas às velocidades médias calculadas, nota-se que apenas para as fontes de matéria orgânica com 1 ou 2 carbonos (ácido fórmico e etanol), o inóculo foi capaz de manter uma adequada velocidade de colonização ao longo do tempo de operação dos sistemas. Na presença de ácido lático, tem-se uma velocidade máxima de crescimento bastante expressiva, porém a velocidade média é muito inferior ao que se observa com os outros dois substratos, conforme já discutido anteriormente. A grande desvantagem, nesse caso, seria a necessidade de se utilizar reatores de grandes volumes (altos tempos de detenção hidráulica) e com grande quantidade de material suporte, ao contrário do que poderia ser feito se a escolha do substrato fosse uma fonte de carbono que permitisse grandes velocidades máximas e médias de crescimento.

Na comparação do inóculo proveniente do sedimento da mina entre os diferentes substratos utilizados, observou-se que nesta condição de menor diversidade de microrganismos, a fonte de carbono desempenha papel determinante. Os ensaios que utilizaram ácido fórmico apresentaram velocidades máximas de crescimento de 0,022 g STV $\mathrm{g}^{-1}$ espuma dia ${ }^{-1}$, enquanto esse valor foi de $0,013 \mathrm{~g} \mathrm{STV} \mathrm{g}^{-1}$ espuma $\mathrm{dia}^{-1}$ para os ensaios com etanol ou ácido lático. A disponibilidade da fonte de carbono mais facilmente oxidável foi capaz de quase dobrar a velocidade máxima de crescimento e ainda permitiu que o sistema mantivesse uma velocidade média bastante próxima aos sistemas que utilizaram um inóculo com maior diversidade. Observa-se, também, que com o ácido fórmico, o tipo de inóculo utilizado não exerceu influência sobre a velocidade máxima, comportamento já observado anteriormente na análise da concentração de sólidos totais voláteis. O mesmo não ocorreu com as outras fontes de carbono, sendo que ambas apresentaram uma queda expressiva na velocidade máxima quando se optou pelo inóculo de sedimento de mina, o que parece confirmar todas as determinações anteriores, que mostraram que na utilização deste inóculo, 
as fontes de matéria orgânica com 2 ou 3 carbonos não favoreceram o crescimento e a aderência dos microrganismos.

Os resultados dos ensaios nos reatores diferenciais permitiram uma escolha mais adequada da fonte de carbono e do inóculo a ser utilizado nos ensaios com o reator anaeróbio horizontal de leito fixo. Considerando os melhores resultados obtidos com o inóculo proveniente do reator tratando água residuária de abatedouro de aves, optou-se por utilizá-lo nos ensaios com os reatores de bancada. Para a fonte de carbono, o etanol foi escolhido, visto que resultou em velocidades de colonização e concentração máxima de STV próximas a do ácido fórmico, porém apresenta menor custo.

\subsection{Determinação do padrão de escoamento dos reatores RAHLF e UASB antes do} início da operação de ambos

O comportamento hidrodinâmico do reator anaeróbio horizontal de leito fixo (RAHLF) e do reator anaeróbio de fluxo ascendente e manta de lodo (UASB) foi avaliado antes da operação dos reatores, quando estes já estavam ou preenchidos com as matrizes de poliuretano sem a inoculação com lodo do abatedouro de aves (RAHLF) ou com a biomassa granular (UASB). O tempo de detenção hidráulica empregado nos ensaios foi o tempo definido no projeto destes reatores: 24 horas.

Os dados obtidos com a realização do ensaio do tipo degrau foram ajustados para obtenção das curvas $\mathrm{F}$ e E, sendo a curva E, representativa da distribuição do tempo de residência. 
A Figura 5.3 (a) apresenta a curva F obtida com o ensaio hidrodinâmico para o TDH teórico de 24 horas e a Figura 5.3 (b) apresenta a curva E (DTR) para esta mesma condição, ambas para o RAHLF.

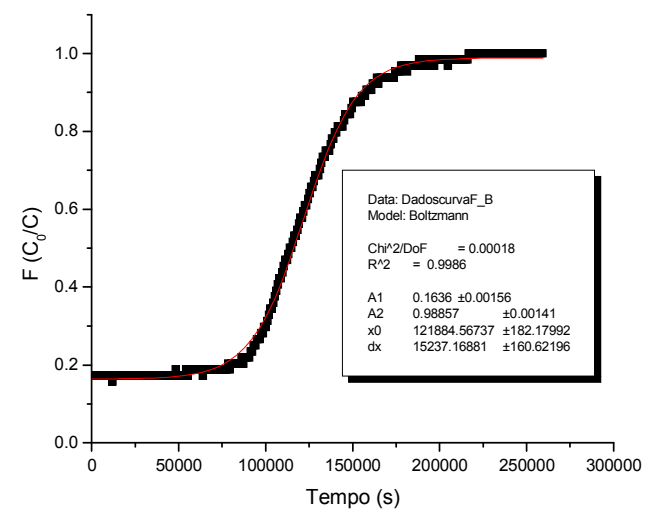

(a)

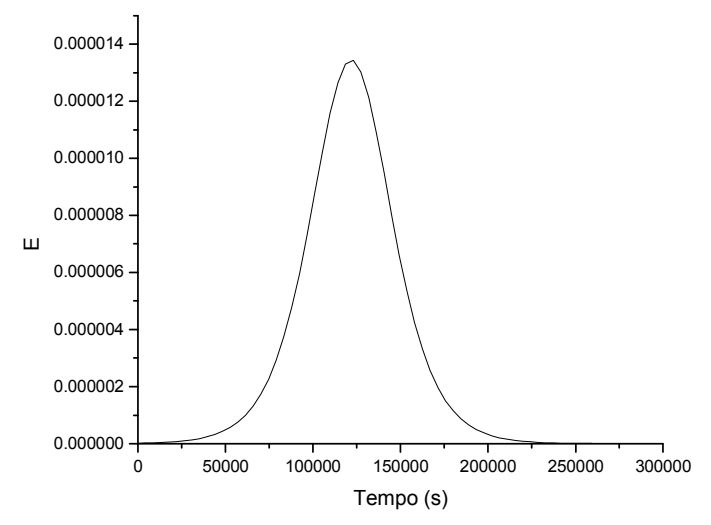

(b)

Figura 5.3. Curva F (a) e curva E (b) obtidas em ensaio do tipo degrau para TDH teórico de 24 horas.

A curva $\mathrm{F}$ apresentou comportamento característico do ensaio do tipo degrau, com patamar final estabelecido e permitiu um ajuste sigmóide com coeficiente de correlação de 0,99. A curva E, derivada obtida a partir do ajuste sigmóide de Boltzman, representou o comportamento do reator com proximidade maior ao tubular ideal (pistonado), escoamento esperado no reator utilizado no presente estudo.

O tempo de detenção hidráulica real, determinado a partir da curva DTR, foi de 33,8 horas para um TDH teórico de 24 horas. Esse aumento no TDH real observado pode ser explicado pela metodologia empregada na determinação do volume útil do reator. A determinação do volume líquido se deu por meio de três drenagens consecutivas do volume útil do reator já preenchido com material suporte. A partir da somatória e média desses volumes drenados obteve-se o volume útil do reator que foi de $1040 \mathrm{ml}$. Quando se realiza o 
estudo do padrão de escoamento, o volume útil obtido (cerca de $30 \%$ maior) é resultado de todo o volume líquido existente entre os interstícios do material suporte e, também, aquele presente no interior do material suporte, que no caso da espuma de poliuretano é bastante significativo em função de sua alta porosidade (acima de 95\%) e da estrutura macroporosa (tamanho de poro médio de $543 \pm 154 \mu \mathrm{m}$ ). No caso da determinação do volume líquido por drenagem, o que se obtém é o volume líquido presente apenas nos interstícios da espuma, resultando em um valor inferior.

Após a determinação do padrão de escoamento do RAHLF, o volume útil empregado na operação do reator foi aquele determinado por drenagens consecutivas $(1040 \mathrm{ml})$ visto que após a inoculação da espuma com o lodo do abatedouro, nota-se significativa diminuição da porosidade do leito e comportamento do líquido mais próximo àquele observado nas drenagens.

Os dados obtidos com a realização do ensaio do tipo degrau para o reator UASB também foram ajustados para obtenção das curvas $\mathrm{F}$ e $\mathrm{E}$, sendo a curva $\mathrm{E}$, representativa da distribuição do tempo de residência. A Figura 5.4 (a) apresenta a curva F obtida com o ensaio hidrodinâmico para o TDH teórico de 24 horas e a Figura 5.4 (b) apresenta a curva E (DTR) para esta mesma condição. 


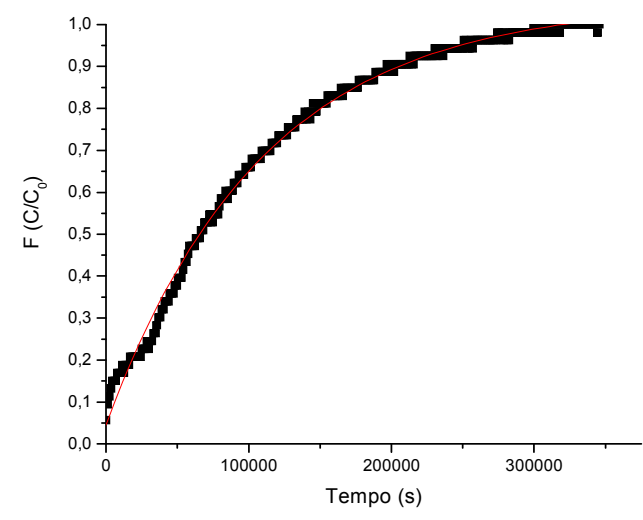

(a)

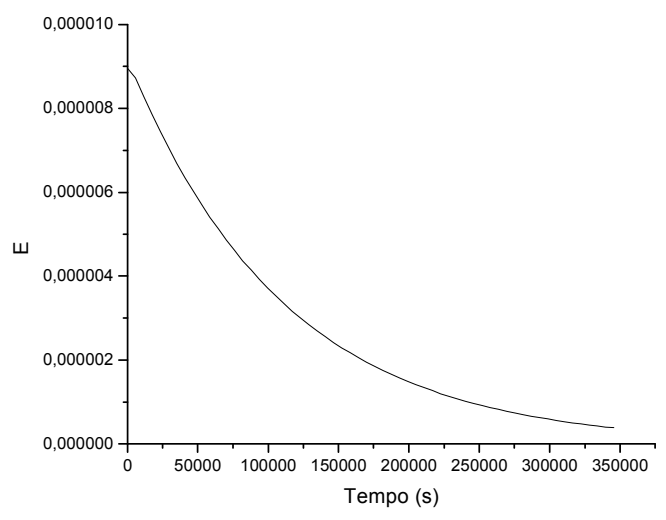

(b)

Figura 5.4. Curva F (a) e curva E (b) obtidas em ensaio do tipo degrau para TDH teórico de 24 horas.

A curva $\mathrm{F}$ apresentou comportamento característico do ensaio tipo degrau, sendo continuamente crescente, tendendo a formar um patamar ao final do experimento. A curva $\mathrm{E}$, obtida derivando-se o ajuste sigmóide de Boltzmann da curva $\mathrm{F}$, representou o comportamento do reator UASB como próximo de um reator de mistura completa. Nestes reatores, uma quantidade de traçador injetada na corrente de alimentação é rapidamente misturada em todo o sistema. Desta maneira, observa-se na saída do reator um contínuo decaimento da concentração do traçador.

O tempo de detenção hidráulica real, determinado a partir das curvas DTR, foi de 26,1 horas para o TDH teórico de 24 horas. O fato de o TDH real observado ser maior do que o TDH teórico pode ser devido a erros na aferição do volume útil do reator, ou de sua vazão. A determinação do volume líquido se deu exatamente como no reator do tipo RAHLF e, portanto, não considerou todo o volume líquido existente no reator que engloba aquele que possa continuar presente entre os interstícios da manta de lodo e que não é retirado por meio de drenagem do líquido. De fato, o valor de volume útil determinado pelas drenagens 
consecutivas correspondeu a $88,4 \%$ do valor determinado durante o estudo do padrão de escoamento.

O emprego de modelos para representação do escoamento nos reatores foi realizado utilizando-se os modelos de N-reatores de mistura completa em série e de dispersão longitudinal para tanques fechados (Levenspiel, 2000). O modelo de N-reatores de mistura completa em série fornece uma idéia sobre o comportamento do reator se este fosse constituído por uma série de reatores de mistura completa de mesmo volume. O número de reatores é representado por $\mathrm{N}$.

O modelo de dispersão longitudinal se baseia inicialmente no modelo de escoamento tipo pistonado, considerando-se, entretanto, que há uma dispersão no escoamento, o que representa o desvio do escoamento ideal. A dispersão longitudinal, portanto, é o único parâmetro desse modelo. O coeficiente de dispersão (D) tem unidade de espaço por tempo (por exemplo, $\mathrm{cm}^{2} \mathrm{~s}^{-1}$ ) e indica quanto o escoamento se desvia da idealidade. A expressão 5.5 apresenta o equacionamento desse modelo (Levenspiel, 2000).

$$
\frac{\partial C}{\partial \theta}=\left(\frac{D}{u \cdot L}\right) \frac{\partial^{2} C}{\partial z^{2}}-\frac{\partial C}{\partial z}
$$

$\mathrm{Na}$ expressão 5.5, $L$ é o comprimento do reator, $u$ é a velocidade do fluido e $(D / u L)$ é o número de dispersão, um adimensional que é utilizado para quantificar o desvio do escoamento pistonado. Quanto este tende a zero, o reator tende a um tubular ideal e quando tende ao infinito, o escoamento tende a mistura perfeita. 
Os resultados encontrados para os dois modelos empregados podem ser visualizados na Tabela 5.4.

Tabela 5.4. Ajuste dos modelos de $\mathrm{N}$ reatores em série e de dispersão longitudinal.

\begin{tabular}{cccc}
\hline Reator & TDH teórico & $\begin{array}{c}\text { N-reatores em série } \\
(\mathbf{N})\end{array}$ & $\begin{array}{c}\text { Dispersão } \\
\text { Longitudinal (D/uL) }\end{array}$ \\
\hline RAHLF & $24 \mathrm{~h}$ & 24 & 0,02 \\
UASB & $24 \mathrm{~h}$ & 1,43 & 0,35 \\
\hline
\end{tabular}

Levenspiel (2000) apresenta curvas de resposta do traçador para tanques fechados e com grandes desvios no escoamento. De acordo com o autor, quanto menor a razão D/uL, mais o regime de escoamento do reator aproxima-se de um pistonado ideal e quando essa razão tende ao infinito, o reator aproxima-se de um reator com escoamento em mistura perfeita.

Para os resultados obtidos no presente trabalho, com o reator RAHLF operado com TDH teórico de 24 horas, tem-se uma razão $\mathrm{D} / \mathrm{uL}$ de 0,02 , característica de um reator mais próximo ao escoamento pistonado. Já o reator UASB mostra-se bastante distante desse comportamento. Com uma razão D/uL de 0,35, de acordo com Levenspiel (2000), a curva para este modelo aproxima-se mais de um reator com comportamento do tipo mistura perfeita.

Quando se analisa os "N" obtidos nas duas condições estudadas, notam-se, também, diferenças significativas no modelo de escoamento. Com base nas curvas do mesmo autor, pode-se aferir a característica de reator pistonado do reator RAHLF obtida com o TDH teórico de 24 horas $(\mathrm{N}=24)$. Fica claro que a condição de TDH teórico de 24 horas é suficiente para que o reator horizontal de leito fixo comporte-se como um reator pistonado representado por condições de N maiores que 20. De acordo com Levenspiel (2000), padrões de escoamento que apresentam $\mathrm{N}$ superiores a 30 podem ser considerados do tipo pistonado 
ideal. O reator UASB, por sua vez, aproxima-se muito de um reator de mistura completa $(\mathrm{N}=1,43)$.

Os estudos hidrodinâmicos realizados nos dois tipos de reatores estudados nesse projeto permitiram identificar que em termos de padrão de escoamento, ambos eram bastante distintos. Além das diferenças com relação a biomassa imobilizada (RAHLF) e biomassa granular (UASB), o escoamento foi outro fator a ser analisado na comparação dos reatores empregados para a remoção do sulfato de drenagem ácida de minas.

\subsection{Ensaios nos Reatores Anaeróbios Horizontais de Leito Fixo - RAHLF}

Os três RAHLF foram analisados conjuntamente em função dos parâmetros estudados para os reatores. Os reatores foram denominados com siglas R1, R2 e R3 para facilitar a identificação dos mesmos.

- Reator Controle (R1): alimentação com drenagem bruta - Análise da influência da relação $\mathrm{DQO} / \mathrm{SO}_{4}{ }^{2-}$ de 0,67 e 1,92 .

- Reator pH 5,0 (R2): alimentação com drenagem bruta e, posteriormente, alimentação com drenagem diluída - Avaliação da influência do pH inicial e da redução da carga de sulfato aplicada.

- Reator afluente diluído (R3): alimentação com drenagem diluída - Avaliação da influência da carga de sulfato, da relação $\mathrm{DQO} / \mathrm{SO}_{4}{ }^{2-}$ e da recirculação do meio líquido. 


\subsubsection{Análise de metais no afluente dos RAHLF}

A análise dos metais em solução presentes na drenagem ácida de minas foi realizada no afluente e efluente dos RAHLF, porém, os resultados encontrados no efluente foram muito inconsistentes, provavelmente, devido aos inúmeros processos de adsorção, desorção, complexação e reações de oxi-redução que parecem ter ocorrido nesses reatores. Em função de alguns problemas operacionais e do tempo restante para análise do leito após o desligamento dos reatores, não foi possível realizar uma análise mais completa sobre a especiação de cada metal ou mesmo, identificar como esse metal estaria presente no leito.

Optou-se, portanto, em se apresentar apenas os resultados dos metais em solução no afluente dos reatores, com o objetivo de auxiliar a discussão dos resultados obtidos com os outros parâmetros de monitoramento.

A Tabela 5.5 apresenta os resultados para os metais $\mathrm{Cr}, \mathrm{Cu}, \mathrm{Ni}, \mathrm{Cd}, \mathrm{Mn}$ e $\mathrm{Zn}$ encontrados no afluente dos reatores R1, R2 e R3.

Tabela 5.5. Concentração de metais no afluente dos reatores R1, R2 e R3.

\begin{tabular}{|c|c|c|c|c|c|c|c|c|}
\hline Reator & Fase & Concentração $\left(\mathrm{mg} \mathrm{l}^{-1}\right)$ & $\mathrm{Cr}$ & $\mathrm{Cu}$ & $\mathbf{N i}$ & Cd & Mn & Zn \\
\hline \multirow{4}{*}{$\mathrm{R} 1$} & \multirow{2}{*}{ I } & Média & 0,0100 & 0,0145 & 0,2740 & 0,0620 & 63,2500 & 5,9140 \\
\hline & & Desvio Padrão & 0,0125 & 0,0100 & 0,1600 & 0,0200 & 18,9700 & 4,0402 \\
\hline & \multirow[t]{2}{*}{ II } & Média & 0,0086 & 0,0153 & 0,2654 & 0,0570 & 64,4300 & 6,7841 \\
\hline & & Desvio Padrão & 0,0114 & 0,0101 & 0,1050 & 0,0140 & 25,8970 & 2,0030 \\
\hline \multirow{4}{*}{$\mathrm{R} 2$} & \multirow{2}{*}{ I } & Média & 0,0096 & 0,0164 & 0,2604 & 0,0620 & 61,1600 & 5,8140 \\
\hline & & Desvio Padrão & 0,0143 & 0,0102 & 0,1500 & 0,0200 & 28,9700 & 5,0302 \\
\hline & \multirow[t]{2}{*}{ II } & Média & 0,0098 & 0,0135 & 0,0905 & 0,0323 & 18,2750 & 4,0050 \\
\hline & & Desvio Padrão & 0,0195 & 0,0056 & 0,0274 & 0,0188 & 0,6344 & 0,5015 \\
\hline \multirow{4}{*}{ R3 } & \multirow{2}{*}{ I } & Média & 0,0456 & 0,0132 & 0,1104 & 0,0320 & 17,3200 & 5,0180 \\
\hline & & Desvio Padrão & 0,0560 & 0,0101 & 0,0378 & 0,0200 & 1,6407 & 3,3811 \\
\hline & \multirow[t]{2}{*}{ II } & Média & 0,0448 & 0,0116 & 0,1484 & 0,0580 & 17,7200 & 3,7100 \\
\hline & & Desvio Padrão & 0,0325 & 0,0117 & 0,0282 & 0,0294 & 0,3271 & 1,4109 \\
\hline
\end{tabular}


Como esperado e de acordo como descrito por Benedeto et al. (2005), os metais Mn e Zn são os que se apresentam em quantidades mais elevadas. Na drenagem bruta, o valor de Mn encontrado foi cerca de metade daquele encontrado pelos autores. No caso do Zn, esse valor foi cerca de $70 \%$ menor. Essa menor concentração de metais pode resultar principalmente da sazonalidade da drenagem, que por estar exposta a céu aberto, está mais diluída nos períodos chuvosos.

Kaksonen e Puhakka (2007) apresentam um diagrama de precipitação de metais na forma de sulfeto e de acordo com os autores, os metais $\mathrm{Cu}, \mathrm{Cd}$ e $\mathrm{Zn}$ precipitam na presença de sulfeto mesmo em condições ácidas ( $\mathrm{pH}$ inferior a 4,5), enquanto o Ni precipita entre $\mathrm{pH}$ de 5,5 a 6,5 e o Mn em pH maior do que 7,0.

5.3.2 Análises de Monitoramento do RAHLF 1 (pH, DQO,concentrações de ácido acético, de sulfato e de sulfeto).

Para esse reator, avaliou-se a influência da relação $\mathrm{DQO} / \mathrm{SO}_{4}{ }^{2-}$ sobre a remoção de sulfato da drenagem ácida bruta. A Figura 5.5 mostra o comportamento do $\mathrm{pH}$ afluente e efluente para o reator $\mathrm{R} 1$.

Durante todas as fases de operação do reator R1, nota-se uma estabilidade na manutenção dos valores de $\mathrm{pH}$ afluente e efluente. $\mathrm{O}$ aumento observado no $\mathrm{pH}$ efluente resulta do consumo de sulfato e consequentemente de íons $\mathrm{H}^{+}$, contribuindo com a geração de certa alcalinidade no efluente. A análise do $\mathrm{pH}$ já permite identificar que na fase II, mesmo com um aporte de elétrons três vezes superior ao da fase I, o reator não apresentou melhora significativa na remoção de íons sulfato e $\mathrm{H}^{+}$. 


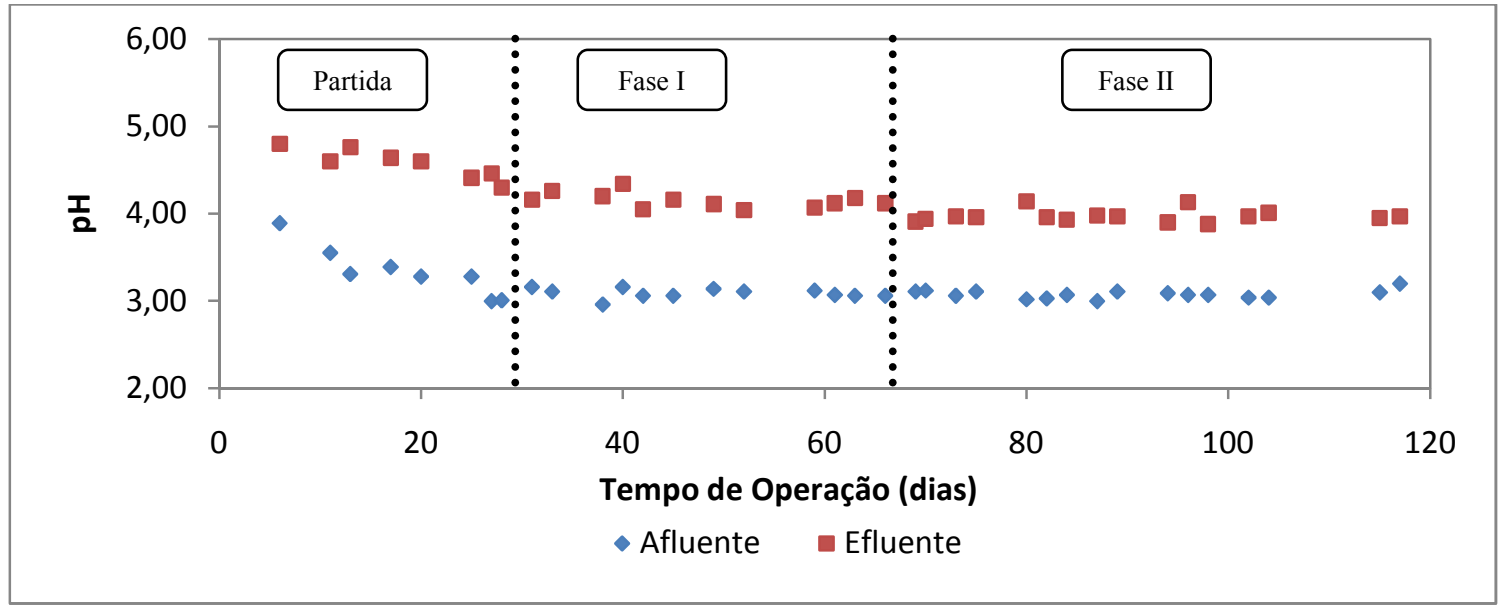

Figura 5.5. Variação do pH afluente ( $\bullet$ e efluente (ם) no RAHLF 1.

A Figura 5.6 mostra o comportamento da DQO na corrente afluente e efluente, bem como a eficiência na remoção da matéria orgânica para o reator R1.

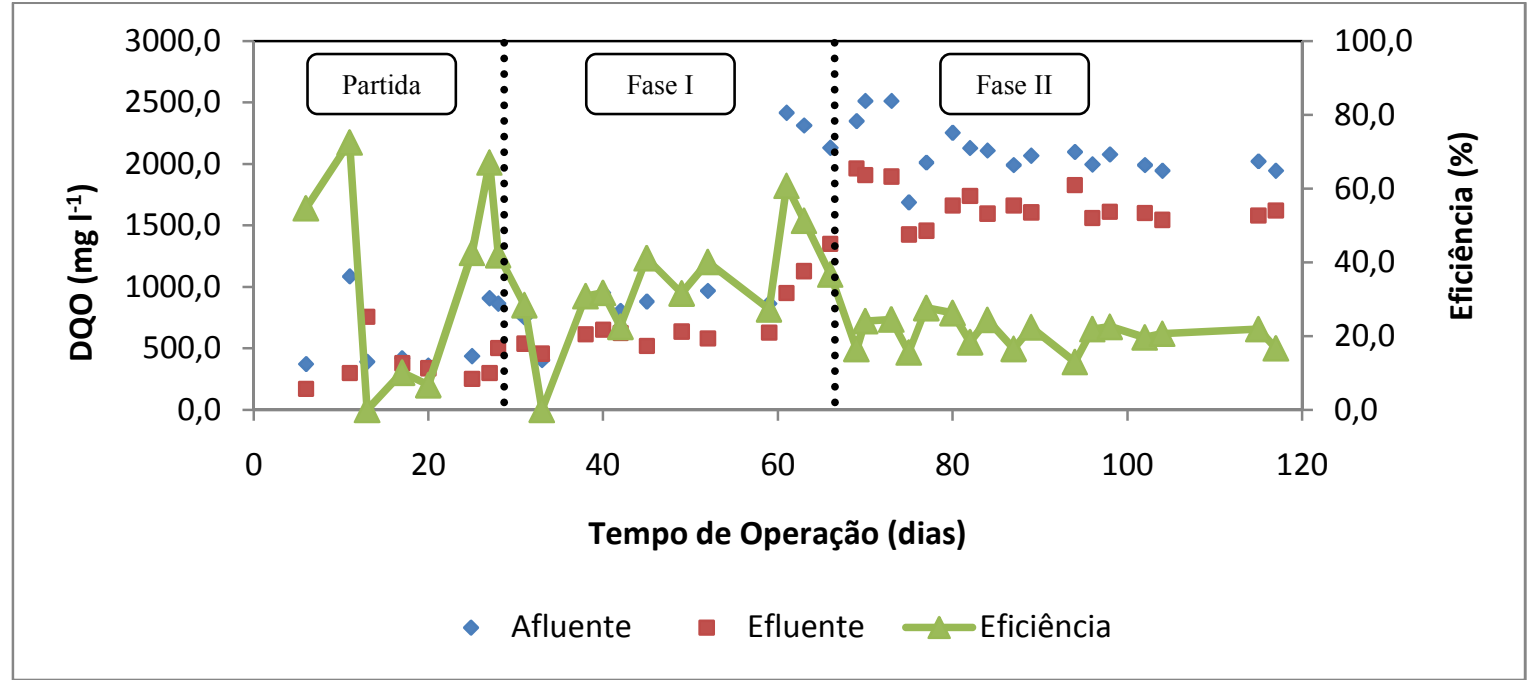

Figura 5.6. Variação da DQO afluente $(\diamond)$, efluente $(\boldsymbol{\square})$ e eficiência de remoção $(\boldsymbol{\Delta})$ no RAHLF 1.

A remoção da DQO apresentou variação significativa no início da operação do reator (primeiros 30 dias) atingindo picos de $70 \%$ de remoção até remoção quase nula. Este comportamento é esperado durante a fase de partida desses sistemas, que contempla um 
período de adaptação e seleção da biomassa capaz de se manter nas condições impostas pela água residuária utilizada. Após o $33^{\circ}$ dia e até o $60^{\circ}$ dia (Fase I), iniciou-se a alimentação do reator com afluente sem diluição na relação $\mathrm{DQO} / \mathrm{SO}_{4}{ }^{2-}$ de 0,67 . Nesse período, observam-se remoções variando entre $20 \%$ e $40 \%$ e média de $32,1 \% \pm 6,1 \%$ com certa estabilidade do sistema. Após quase 70 dias de ensaio (Fase II), a corrente afluente foi alterada para que a relação $\mathrm{DQO} / \mathrm{SO}_{4}{ }^{2-}$ fosse de 1,92 e, nota-se que rapidamente o sistema tornou-se estável, com remoções médias de $25,0 \% \pm 11,8 \%$ até o final da operação.

O comportamento do reator foi bastante sensível a alteração na constituição do afluente, ficando claro que o aumento na relação $\mathrm{DQO} / \mathrm{SO}_{4}{ }^{2-}$ contribuiu para a estabilidade do sistema, porém com diminuição na eficiência de remoção da matéria orgânica.

As condições desfavoráveis da drenagem ácida de mina bruta parecem ter dificultado o funcionamento deste reator. $\mathrm{O}$ baixo $\mathrm{pH}$, a alta carga de sulfato e de metais pode ter impedido o estabelecimento de uma biomassa mais ativa e específica para esse processo. $\mathrm{O}$ sulfato e os metais em altas concentrações podem ser tóxicos a flora microbiana e o baixo $\mathrm{pH}$, por sua vez, seleciona microrganismos com características acidofílicas. Sendo o inóculo utilizado um consórcio microbiano mesofílico em sua maior parte, era esperado que no curto espaço de tempo de operação desse reator, não fosse possível a seleção e o crescimento adequado da biomassa capaz de suportar as condições impostas.

Em um reator sulfetogênico de leito expandido alimentado com etanol, De Smul et al. (1997) notaram que em $\mathrm{pH}$ mais alcalino, a atividade das bactérias redutoras de sulfato foi fortemente estimulada, enquanto em $\mathrm{pH}$ ácido, notou-se maior inibição pelo sulfeto de hidrogênio.

Conjuntamente às análises de DQO, foram realizadas análises por cromatografia gasosa para a determinação de ácido acético nas correntes afluente e efluente. A Figura 5.7 
apresenta a variação na concentração de ácido acético efluente descontada do que foi determinado no afluente ao longo da operação do reator.

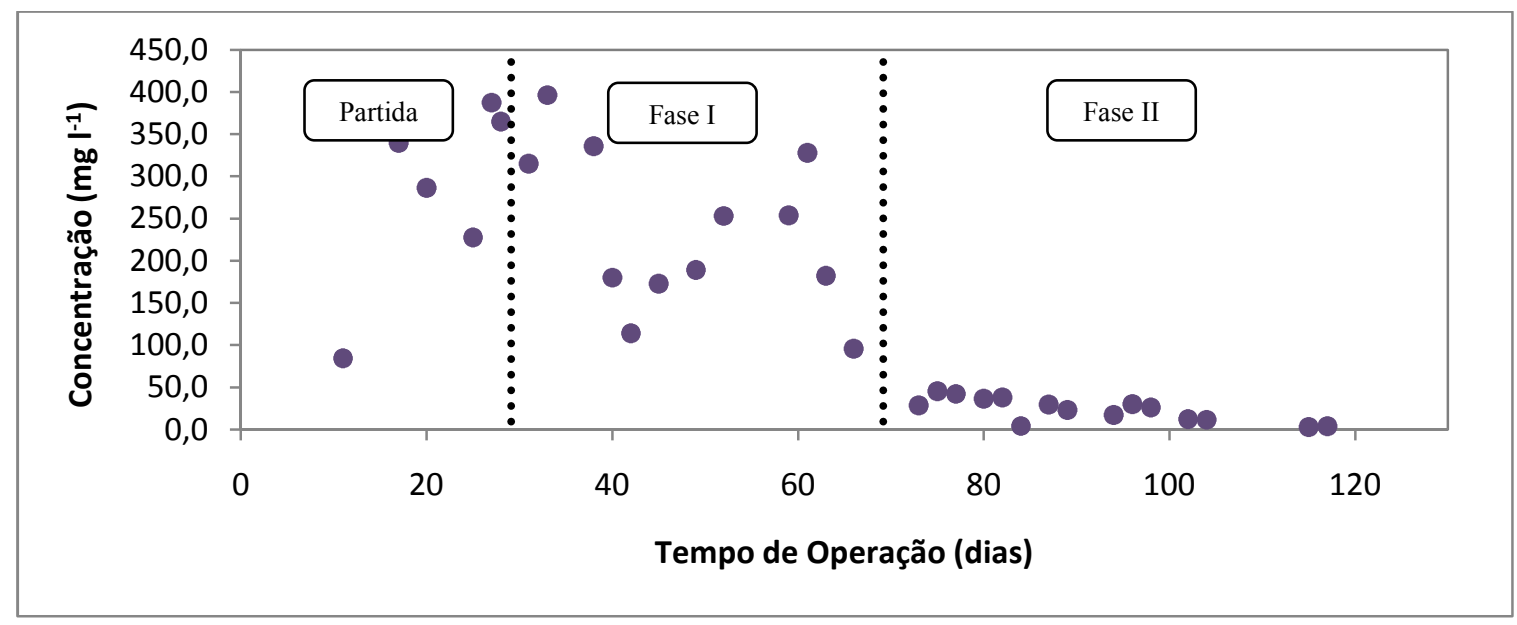

Figura 5.7. Variação da concentração de ácido acético (efluente - afluente) no RAHLF 1.

A presença significativa de ácido acético no efluente nos primeiros 66 dias de operação do reator demonstra que a via principal de utilização do etanol durante a fase que se utilizou a relação $\mathrm{DQO} / \mathrm{SO}_{4}{ }^{2-}$ de 0,67 foi a oxidação incompleta da matéria orgânica e isso poderia explicar a baixa remoção de DQO observada nesse período.

Hansen (1994) descreve que grande parte das bactérias redutoras de sulfato realiza como via preferencial a oxidação incompleta do substrato quando o etanol está presente como doador de elétrons. A oxidação do etanol a acetaldeído e, em seguida, a acetato é uma reação mediada pela enzima álcool desidrogenase NAD-dependente, presente em muitas espécies de bactérias redutoras de sulfato, como exemplifica o autor.

Sendo a oxidação incompleta a via preferencial da biomassa presente no reator em estudo, pode-se inferir que a redução do sulfato presente no afluente não ocorreria em sua totalidade, visto que a quantidade de elétrons transportada através da cadeia respiratória na 
oxidação do etanol a acetato seria insuficiente para reduzir todo o sulfato presente na drenagem ácida de minas (cerca de $1200 \mathrm{mg}^{1^{-1}}$ ).

Após a análise desses resultados iniciais (até 66 dias de operação), optou-se por aumentar em cerca de três vezes a relação $\mathrm{DQO} / \mathrm{SO}_{4}{ }^{2-}$ numa tentativa de oferecer ao sistema a quantidade de elétrons necessária para a remoção completa de sulfato. A grande modificação observada foi que a matéria orgânica utilizada na segunda fase foi oxidada completamente, com baixo acúmulo de ácido acético no efluente, enquanto na etapa anterior, ficou claro que grande parte do etanol utilizado era levada a ácido acético via dissimilação incompleta da matéria orgânica.

A redução na eficiência de remoção da DQO na fase II talvez não tenha refletido uma melhora no sistema, porém em relação à carga orgânica removida, a biomassa foi capaz de degradar uma maior quantidade de matéria orgânica. Enquanto na fase I, a média de remoção de matéria orgânica foi de $0,29 \mathrm{~g} \mathrm{DQO}^{-1} \mathrm{dia}^{-1}$, na fase II, essa remoção aumentou para $0,54 \mathrm{~g}$ DQO $1^{-1} \operatorname{dia}^{-1}$. A estabilidade da fase II pode também refletir uma adaptação do sistema ao longo do tempo às condições da água residuária em questão.

Ficou claro, entretanto, que o excesso de doador de elétrons disponíveis promoveu uma mudança na rota metabólica de oxidação da matéria orgânica não sendo detectadas quantidades significativas de ácido acético no efluente do reator na fase II. O aumento da relação DQO/ $\mathrm{SO}_{4}{ }^{2-}$ é indicado por muitos autores (Silva et al., 2002; Lens et al., 1998) como uma maneira de favorecer o metabolismo de outros grupos bacterianos e desfavorecer as BRS. É provável que na tentativa de melhorar a redução do sulfato com o maior aporte de elétrons, tenham se estabelecido condições mais favoráveis a outros grupos bacterianos que não as redutoras de sulfato. 
A remoção de sulfato no reator R1 pode ser acompanhada pela Figura 5.8. A concentração de sulfato afluente esteve sempre entre 1100 e $1200 \mathrm{mg} \mathrm{l}^{-1}$ e correspondia a concentração encontrada na drenagem ácida de mina bruta, sem tratamento algum.

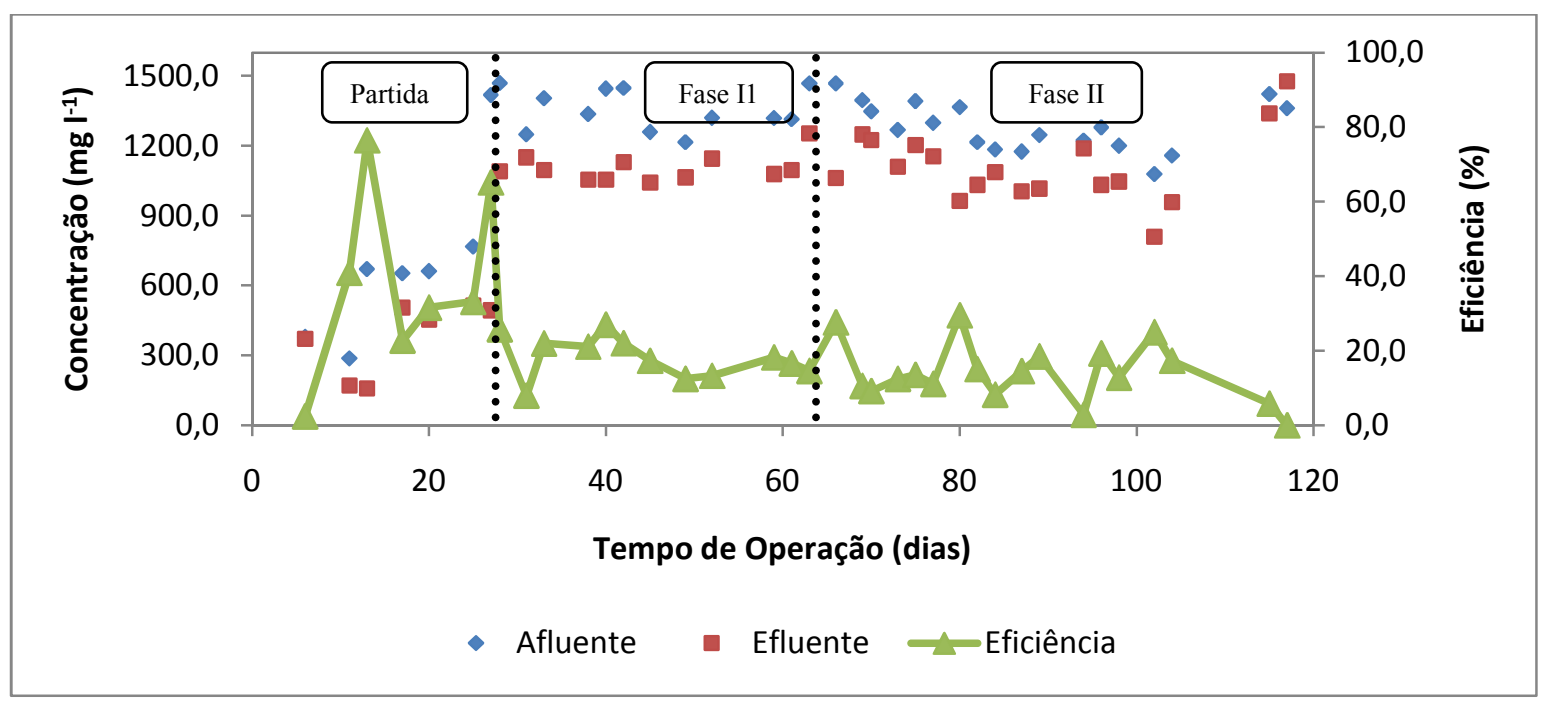

Figura 5.8. Variação da concentração de sulfato afluente ( $\bullet$, efluente (๘) e eficiência de remoção $(\boldsymbol{\Delta})$ no RAHLF 1.

A remoção de sulfato está diretamente ligada ao consumo da matéria orgânica, visto que nas condições do presente estudo, o sulfato atua preferencialmente como receptor de elétrons. As máximas reduções de sulfato obtidas entre o $30^{\circ}$ e $66^{\circ}$ dia de operação do reator foram cerca de $30 \%$, estando em média $17,3 \% \pm 4,9 \%$ e carga média removida de $0,24 \mathrm{~g} \mathrm{l}^{-1}$ dia $^{-1}$ e parecem ser resultado do metabolismo preferencial da biomassa redutora de sulfato presente no reator que nesta etapa foi a oxidação incompleta do etanol, mostrada no gráfico de concentrações de ácido acético. Na oxidação incompleta do etanol apenas um terço dos elétrons que seriam transportados na oxidação completa são liberados para o recebedor final da cadeia respiratória, neste caso, o sulfato (equação 5.2). 
$\mathrm{SO}_{4}^{2-}+2 \mathrm{CH}_{3} \mathrm{CH}_{2} \mathrm{O}^{-} \rightarrow 2 \mathrm{CH}_{3} \mathrm{COO}^{-}+\mathrm{S}^{2-}+2 \mathrm{H}_{2} \mathrm{O}$

Portanto, a razão estequiométrica $\mathrm{DQO} / \mathrm{SO}_{4}{ }^{2-}$ passa de 0,67 (oxidação completa) para 1,92 quando a via preferencial for a dissimilação incompleta. Dessa forma, é esperado que, no máximo, $30 \%$ do sulfato presente seja reduzido a sulfeto na razão 0,67 . Como se observa queda na DQO efluente, parte da oxidação da matéria orgânica parece ocorrer através da via dissimilatória completa, permitindo eficiências de remoção de sulfato ligeiramente satisfatórias, porém esta via não seria a preferencial neste reator.

Damianovic e Foresti (2007) operando reator horizontal de leito fixo com concentrações de sulfato superiores a utilizada neste ensaio (2000 a $3000 \mathrm{mg} \mathrm{l}^{-1}$ ) demonstram que a eficiência de redução do sulfato é superior a $90 \%$ quando a relação $\mathrm{DQO} / \mathrm{SO}_{4}{ }^{2-}$ é superior a 2,0 na presença de etanol como doador de elétrons.

Considerando que a remoção de matéria orgânica foi $0,29 \mathrm{~g} \mathrm{DQO}{ }^{-1} \mathrm{dia}^{-1}$ e que a via principal de oxidação seria a via incompleta, espera-se uma remoção mássica de sulfato de cerca de $0,3 \mathrm{~g} \mathrm{SO}_{4}{ }^{2-} 1^{-1} \mathrm{dia}^{-1}$. Porém, a remoção de sulfato observada foi de $0,23 \mathrm{~g} \mathrm{SO}_{4}{ }^{2-} 1^{-1} \mathrm{dia}^{-}$ 1, valor inferior ao esperado, o que significa que parte do sulfato removido possa ter sido oxidado parcialmente a enxofre elementar. Essa observação, inclusive, pôde ser feita visualmente sobre o leito do reator.

De acordo com a equação 5.2, se a via incompleta de oxidação do etanol foi a única presente neste reator durante a fase I, a quantidade de ácido acético no efluente deveria ser $0,38 \mathrm{~g}$ ácido acético $\mathrm{l}^{-1} \mathrm{dia}^{-1}$. Entretanto, as análises de ácido acético resultaram em uma carga média de $0,2 \mathrm{~g}$ ácido acético $1^{-1} \operatorname{dia}^{-1}$, o que pode indicar que parte do ácido acético era oxidado a gás carbônico e água por outro grupo de microrganismos, por exemplo, as arqueias 
metanogênicas, que segundo as análises de biologia molecular, estavam presentes nesse reator. Entretanto, a dificuldade de análise da fase gasosa no RAHLF, impediu a detecção de gás metano, que se estivesse presente, estaria em quantidades muito baixas.

Os resultados da fase II, porém, mostraram que a eficiência da remoção de sulfato não foi melhorada com o maior aporte de elétrons, permanecendo em $13,8 \% \pm 8,6 \%$. A carga de sulfato removida ficou em $0,19 \mathrm{~g} \mathrm{SO}_{4}{ }^{2-} 1^{-1} \mathrm{dia}^{-1}$, abaixo da obtida na fase I. Como mostrado nos resultados de DQO, a oxidação da matéria orgânica não melhorou em termos de eficiência, mas a carga removida foi maior na fase II. Com uma remoção de $0,54 \mathrm{~g}$ DQO ${ }^{-1}$ dia $^{-1}$, era esperada uma remoção de sulfato de $0,53 \mathrm{~g} \mathrm{SO}_{4}{ }^{2-} 1^{-1} \operatorname{dia}^{-1}$ pela via dissimilatória incompleta e de $1,7 \mathrm{~g} \mathrm{DQO}^{-1}$ dia $^{-1}$ no caso da dissimilação completa. Esses valores estão muito acima do obtido e as análises de ácido acético detectaram concentrações diminutas na saída do reator. Portanto, grande parte da matéria orgânica utilizada nessa fase não foi consumida por bactérias redutoras de sulfato ou, se foi, outros receptores de elétrons foram utilizados pelas BRS.

Tang et al. (2009) citam que o íon férrico e o urânio VI poderiam atuar como receptores de elétrons para algumas espécies de BRS. Considerando-se que a água residuária em questão provém de um local de mineração de urânio e com rochas ricas em sulfeto férrico oxidado, seria muito provável que estes elementos estivessem utilizando parte dos elétrons provenientes da oxidação do etanol e, dessa forma, impedindo que o íon sulfato funcionasse como único receptor de elétrons.

A segunda possibilidade envolve a presença de bactérias fermentativas nesse sistema. As bactérias fermentativas oxidam parcialmente a fonte de carbono até o íon acetato. Imagens de microscopia ótica comum revelaram a presença de microorganismos como morfologias semelhantes a fermentativas no reator em estudo (Figura 5.9). Essa competição pela fonte de 
energia resultaria em menor disponibilidade de elétrons para as bactérias redutoras de sulfato e, assim, a quantidade de sulfato reduzida seria inferior àquela esperada em função da oxidação da matéria orgânica.

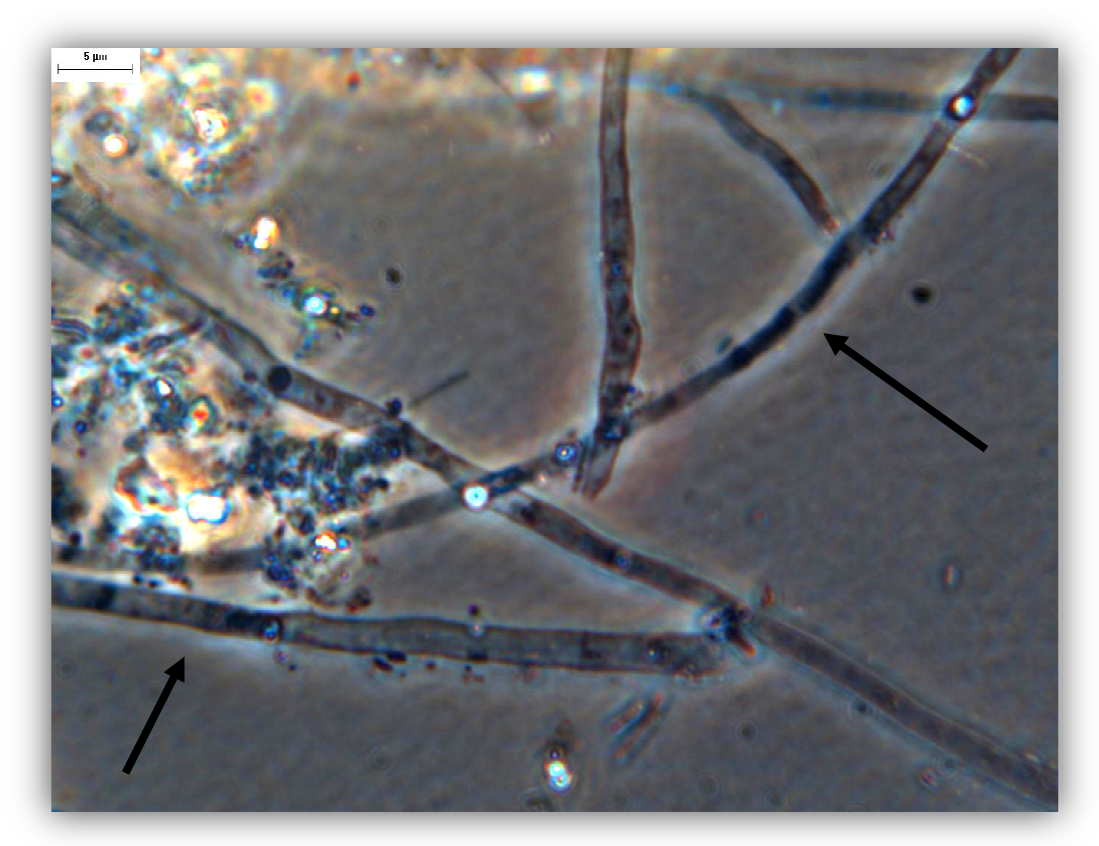

Figura 5.9. Imagem de bactéria como morfologia semelhante a bactérias fermentativas encontrada no leito do RALHF 1.

Outra alternativa que poderia explicar a baixa eficiência desse reator seria a toxicidade provocada pelo íons metálicos, pelo baixo $\mathrm{pH}$ ou pelo sulfeto de hidrogênio produzido durante o processo (Shayegan et al., 2005).

As análises de sulfeto foram realizadas tanto no afluente como no efluente, porém em função do baixo $\mathrm{pH}$ da drenagem, todo o sulfeto estaria na forma de $\mathrm{H}_{2} \mathrm{~S}$ e, com isso, nas determinações no afluente, os valores foram sempre nulos. O gráfico de monitoramento mostra, portanto, apenas as concentrações no efluente. A Figura 5.10 apresenta as concentrações de sulfeto determinadas no efluente do reator R1. 


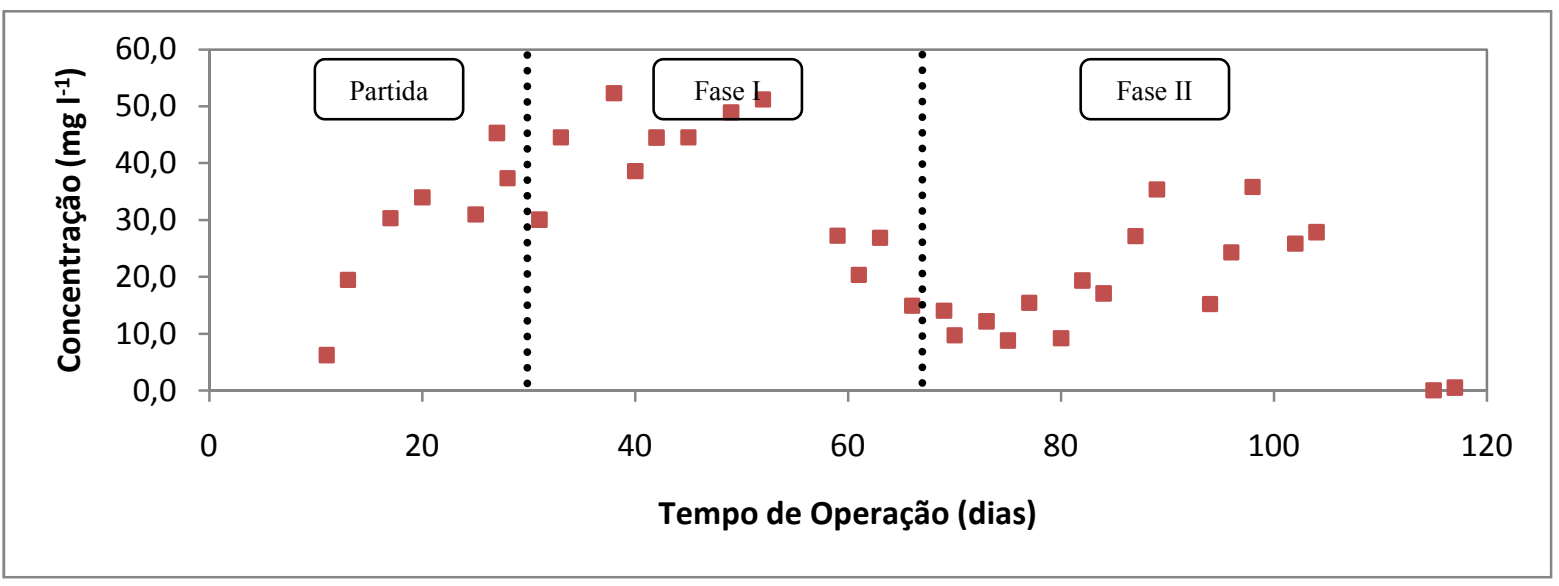

Figura 5.10. Variação da concentração de sulfeto efluente (घ) no RAHLF 1.

Notou-se intensa variação na concentração de sulfeto efluente, sem uma relação direta com a redução de sulfato obtida para esse reator. Durante a fase I, a concentração de sulfeto foi $39,0 \pm 10,4 \mathrm{mg} \mathrm{l}^{-1}$, enquanto na fase II, foi de $27,4 \pm 13,9 \mathrm{mg} \mathrm{l}^{-1}$. Uma das grandes dificuldades nesse trabalho foi exatamente melhorar os resultados dessa análise, pois em função do baixo $\mathrm{pH}$ da água residuária estudada, todo o sulfeto formado migraria para a forma gasosa $\left(\mathrm{H}_{2} \mathrm{~S}\right)$, sendo disperso rapidamente na atmosfera após a coleta do efluente. As análises de sulfeto foram utilizadas, de fato, como indicativos do funcionamento da sulfetogênese e também puderam oferecer algum ideia sobre possíveis problemas com toxicidade.

Os resultados de sulfeto nesse reator, porém, indicaram o que foi observado para a remoção de sulfato. O início da fase II prejudicou a remoção de sulfato e isso se refletiu na concentração de sulfeto efluente analisada. Entretanto, as concentrações de sulfeto sempre estiveram muito abaixo daquela teórica esperada em relação ao sulfeto removido ( $240 \mathrm{mg}^{-1}$ de sulfato removido na fase I e $190 \mathrm{mg}^{-1}$ de sulfato removido na fase II). 
5.3.3 Análises de Monitoramento do RAHLF 2 (pH, DQO,concentrações de ácido acético, de sulfato e de sulfeto).

No reator R2, avaliou-se na fase I, a influência da correção do $\mathrm{pH}$ da drenagem bruta afluente para 5,0 e, posteriormente, na fase II, a carga de sulfato aplicada foi reduzida para próximo de $300 \mathrm{mg} \mathrm{1-1} \mathrm{através} \mathrm{de} \mathrm{diluição} \mathrm{com} \mathrm{água} \mathrm{de} \mathrm{abastecimento.} \mathrm{A} \mathrm{Figura} 5.11$ mostra o comportamento do pH resultante da operação do reator R2.

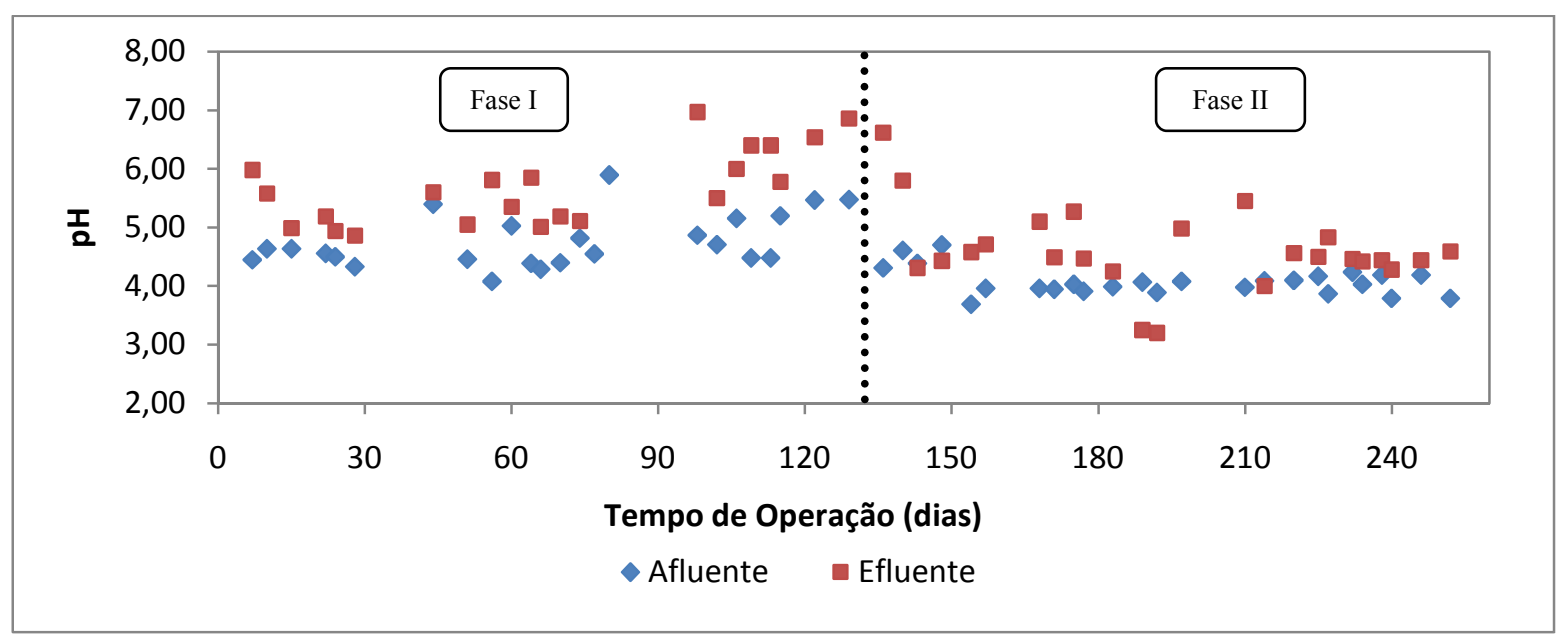

Figura 5.11. Variação da pH afluente (») e efluente (•) no RAHLF 2.

Diferentemente do reator $\mathrm{R} 1$, no reator $\mathrm{R} 2$, o $\mathrm{pH}$ afluente era ajustado para próximo de 5,0 com a adição de $\mathrm{NaOH}$. Isso já contribuía para que o $\mathrm{pH}$ final estivesse um pouco superior ao observado no reator controle (R1). Entretanto, na fase I de operação do reator R2, nota-se muita instabilidade nos valores de $\mathrm{pH}$ efluente, um reflexo do que foi observado neste reator em termos de eficiências de remoção de DQO e sulfato (mostrados mais adiante). Os valores de $\mathrm{pH}$ na saída do reator estiverem entre 5,0 e 6,5, porém não mostraram um comportamento estável. Com a mudança na alimentação na fase II, o pH afluente ficou menor, já que não era 
mais corrigido com $\mathrm{NaOH}$, porém o $\mathrm{pH}$ efluente variou em um intervalo menor, entre 4,5 e 5,0, o que sugere que nesta fase, o reator estaria operando de maneira mais estável.

A Figura 5.12 apresenta os valores de DQO afluente e efluente obtidos ao longo da operação do reator R2, além da eficiência de remoção da matéria orgânica.

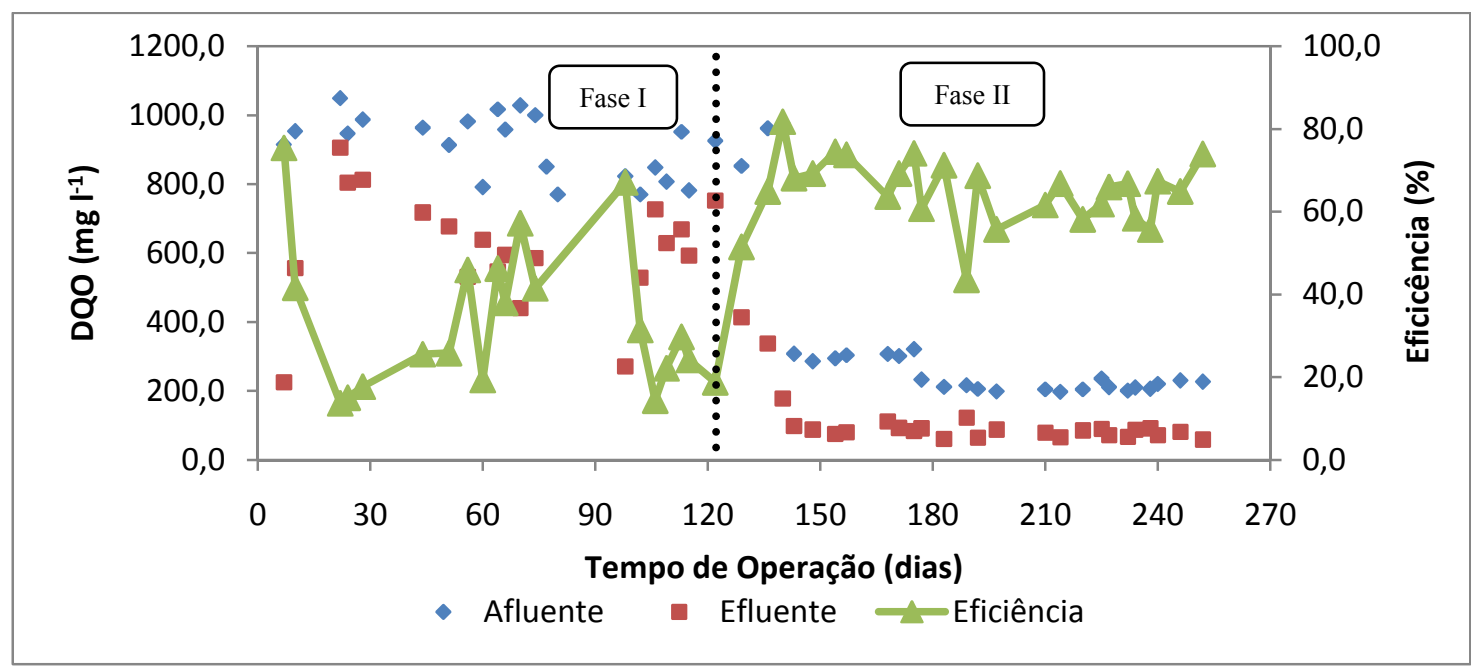

Figura 5.12. Variação da DQO afluente $(\diamond)$, efluente $(\boldsymbol{\bullet})$ e eficiência de remoção $(\boldsymbol{\Delta})$ no RAHLF 2.

A alteração na alimentação do reator estudado resultou em comportamentos distintos com relação à oxidação da matéria orgânica. As remoções de matéria orgânica observadas na fase I foram bastante instáveis ao longo da operação do sistema, com eficiências baixas e altas durante os primeiros 130 dias de operação. A remoção média de DQO foi de $37,8 \% \pm 20,5 \%$. Após esse período, com a substituição da corrente afluente por uma alimentação com drenagem diluída (fase II), ficou evidente que a redução da carga de sulfato aplicada determinou uma maior utilização da matéria orgânica, com eficiências estáveis e superiores a $60 \%$ e em média de $65,0 \% \pm 7,4 \%$. Dessa maneira, para o inóculo utilizado, que possui alta diversidade bacteriana, foi necessário o favorecimento de comunidades específicas responsáveis pela utilização de etanol como doador de elétrons à redução do sulfato e que só 
conseguiram se estabelecer, provavelmente, em função da redução na concentração de sulfato da alimentação.

Em relação a carga orgânica removida, na fase I, a média foi de $0,36 \mathrm{~g} \mathrm{DQO}{ }^{-1} \mathrm{dia}^{-1}$, enquanto na fase II foi $0,20 \mathrm{~g}$ DQO $\mathrm{l}^{-1} \mathrm{dia}^{-1}$. O sistema foi capaz de remover uma quantidade maior de DQO em termos mássicos na fase I, porém de maneira muito instável, além do custo com a correção de $\mathrm{pH}$ da corrente afluente. A diminuição na carga orgânica e de sulfato aplicada torna o sistema mais estável e, tentativas de adaptação com cargas crescentes ao longo do tempo poderiam ser propostas após o estabelecimento desse período mais estável de funcionamento.

A correção do $\mathrm{pH}$ inicial e a menor carga de sulfato no afluente foram parâmetros importantes nos estudos de remoção de sulfato e de metais em reatores de fluxo descendente (McCauley et al., 2009). Os autores concluíram que as melhores velocidades de remoção se sulfato ocorreram quando a carga de sulfato aplicada era de $30 \mathrm{~g} \mathrm{~m}^{-3} \mathrm{dia}^{-1}$ e quando se utilizavam compostos que produziam alcalinidade no sistema. No caso do reator R2, as melhores eficiências de sulfato deram-se quando a carga orgânica aplicada foi cerca de $0,2 \mathrm{~g} \mathrm{l}^{-}$ ${ }^{1} \mathrm{dia}^{-1}$ e a carga de sulfato de $0,35 \mathrm{~g} \mathrm{l}^{-1} \mathrm{dia}^{-1}$.

Tsukamoto et al. (2004) também reforçam a importância da elevação do pH afluente para diminuir o tempo de adaptação do consórcio microbiano redutor de sulfato.

A Figura 5.13 mostra o acúmulo de ácido acético efluente determinado ao longo da operação do reator R2. 


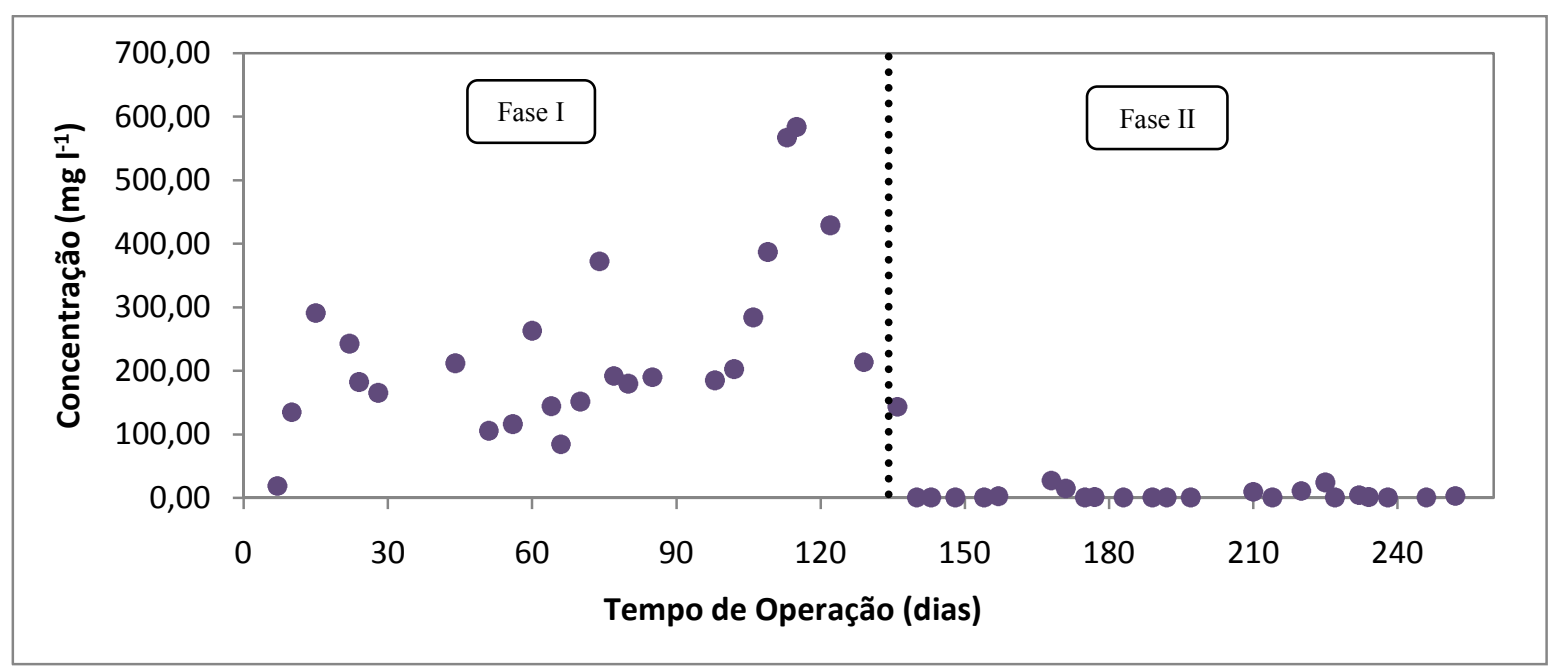

Figura 5.13. Variação da concentração de ácido acético (efluente - afluente) no RAHLF 2.

No reator R2, observaram-se concentrações bem superiores a $100 \mathrm{mg} \mathrm{l}^{-1}$ durante a operação da fase I, com média de $240,0 \pm 144 \mathrm{mg}$ ácido acético $\mathrm{1}^{-1}$. Com a mudança na corrente de alimentação para uma contendo drenagem diluída, nota-se uma mudança no comportamento do reator, com queda brusca na concentração efluente de ácido acético a valores inferiores a $20 \mathrm{mg} \mathrm{l}^{-1}$ e média de $10,9 \pm 9,5 \mathrm{mg}$ ácido acético $\mathrm{l}^{-1}$.

A redução nas cargas de DQO e sulfato aplicadas na fase II provocaram uma mudança na rota metabólica de oxidação da matéria orgânica utilizada, que passou a ser oxidada completamente. Estima-se que as menores cargas aplicadas poderiam ter favorecido o estabelecimento de bactérias redutoras de sulfato capazes de oxidar completamente a matéria orgânica, mas que seriam mais sensíveis à exposição a maiores cargas orgânicas e de sulfato. As bactérias redutoras de sulfato completas normalmente utilizam acetato como substrato, entretanto, sabe-se que inúmeras espécies podem crescer em substratos diferenciados, como etanol, ácidos voláteis de cadeia curta e compostos aromáticos (Widdel, 1988 apud Muyzer e Stams, 2008). 
A Figura 5.14 apresenta os resultados de remoção de sulfato obtidos com o reator R2 na fase I, com correção do pH afluente e na fase II, com redução da carga orgânica e sulfato afluente resultado da diluição com água de abastecimento.

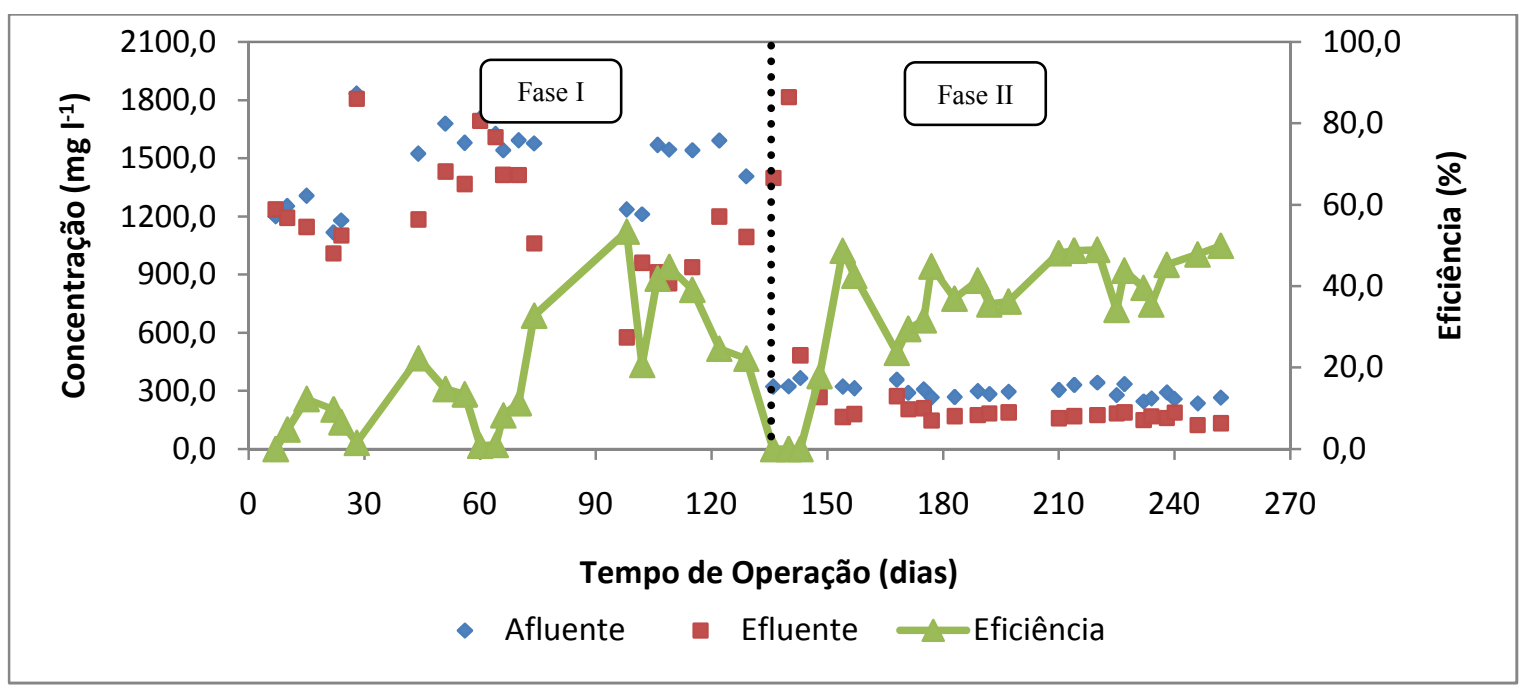

Figura 5.14. Variação da concentração de sulfato afluente ( $\bullet$ ), efluente (घ) e eficiência de remoção ( $\mathbf{\Delta})$ no RAHLF 2.

A remoção de sulfato no reator R2 não apresentou eficiências muito elevadas. Durante o período de correção do pH afluente (fase I) notou-se um remoção bastante instável do íon sulfato, com variações desde $0 \%$ até $50 \%$ e média de $18,4 \% \pm 15,9 \%$. A carga média removida de sulfato nessa fase foi de $0,25 \mathrm{~g} \mathrm{SO}_{4}{ }^{2-} 1^{-1} \mathrm{dia}^{-1}$. Nessa fase foi observado que a adição de $\mathrm{NaOH}$ na drenagem ácida para elevação do $\mathrm{pH}$ até 5,0 provocava o aparecimento de uma substância coloidal no frasco de alimentação. Acredita-se que esse colóide aprisionava alguns íons presentes na drenagem, entre eles o íon sulfato, já que notava-se ligeira queda na concentração média de sulfato na corrente de alimentação.

Após a mudança no regime de alimentação do R2 para o afluente contendo drenagem diluída, observa-se uma remoção de sulfato um pouco mais elevada, com a eficiência variando entre $30 \%$ e $50 \%$ e em média de $40,6 \% \pm 7,5 \%$ entre o $154^{\circ}$ e $252^{\circ}$ dia de operação. 
A carga média de sulfato removida nessa fase foi de $0,12 \mathrm{~g} \mathrm{SO}_{4}{ }^{2-} 1^{-1} \mathrm{dia}^{-1}$. O incremento na remoção de sulfato após a mudança para a fase II foi menos significativo do que o efeito sobre a DQO, cuja eficiência foi quase o dobro da fase anterior.

É provável que após 130 dias de operação em condições não adequadas às BRS, estas não conseguiram se recuperar com maior eficiência após a diminuição da carga de sulfato aplicada. Nesse caso, outros microrganismos estariam utilizando o etanol na fase II e não somente as redutoras de sulfato. Outra questão refere-se ao fato de que com o aprisionamento de parte do sulfato na substância coloidal, este tivesse sido adsorvido no leito do reator e, após a mudança na alimentação, esse sulfato tenha sido liberado aos poucos, o que daria a falsa impressão de que a remoção de sulfato não teria sofrido grande melhora. A Figura 5.16 mostra que logo após a mudança na condição de alimentação, a eficiência nos primeiros dias foi nula e notou-se grande quantidade de sulfato sendo liberada na corrente efluente, em valores superiores ao que era adicionado. Essa concentração excessiva de sulfato detectada, provavelmente, resultou dos complexos adsorvidos no leito do reator e que quando na presença de uma alimentação mais diluída e sem formação de colóide, migraram para a porção líquida e foram liberados no efluente.

A Figura 5.15 mostra o grande acúmulo de polímeros e substância coloidal na porção inicial do reator R2 durante a fase I. 


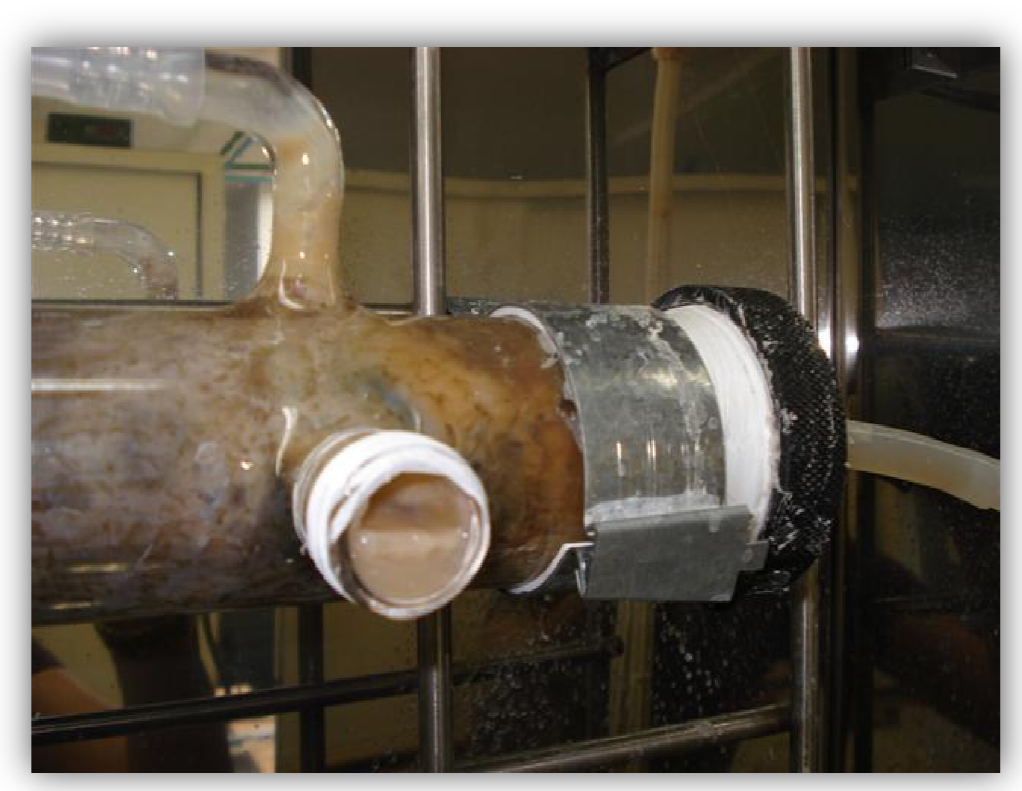

Figura 5.15. Porção inicial do reator R2.

As análises de sulfeto no reator R2 (Figura 5.16) também apresentaram as mesmas dificuldades encontradas no reator R1. Notou-se grande instabilidade nos resultados de sulfeto efluente durante as duas fases de operação desse reator.

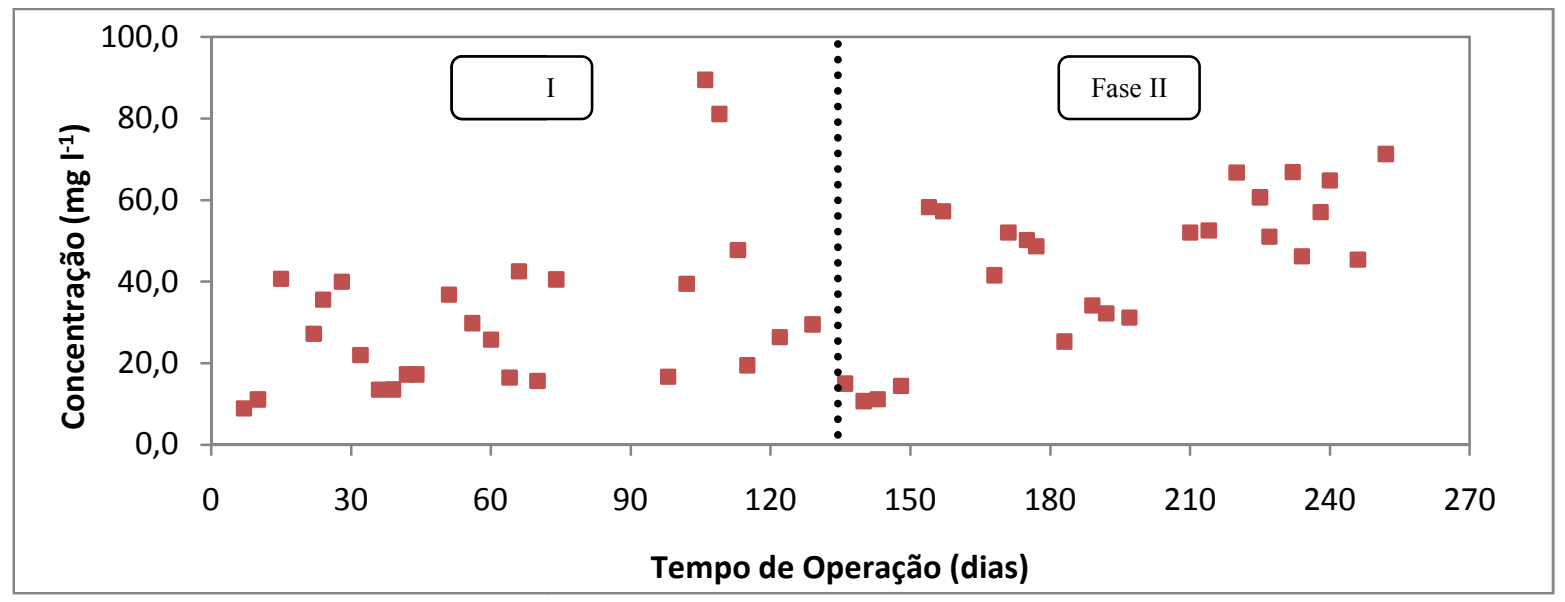

Figura 5.16. Variação da concentração de sulfeto efluente (ロ) no RAHLF 2.

$\mathrm{Na}$ fase I, a concentração média efluente foi $30,9 \pm 19,5 \mathrm{mg}^{-1}$ e na fase II, essa concentração foi de $44,7 \pm 18,3 \mathrm{mg}^{-1}$. Na fase I, a concentração encontrada esteve abaixo da 
teórica em função da remoção de sulfato, porém na fase II, foi possível determinar o sulfeto com maior precisão, visto que em função da carga de sulfato removida nessa fase $\left(120 \mathrm{mg} \mathrm{l}^{-1}\right.$ $\operatorname{dia}^{-1}$ ) seria esperada uma concentração de sulfeto de cerca de $40 \mathrm{mg} \mathrm{l}^{-1} \mathrm{dia}^{-1}$.

5.3.4 Análises de Monitoramento do RAHLF 3 (pH, DQO,concentrações de ácido acético, de sulfato e de sulfeto).

O reator R3 foi alimentado com uma concentração reduzida de sulfato afluente, obtida pela diluição da drenagem ácida com água de abastecimento. A Figura 5.17 apresenta os valores de $\mathrm{pH}$ durante a operação desse reator.

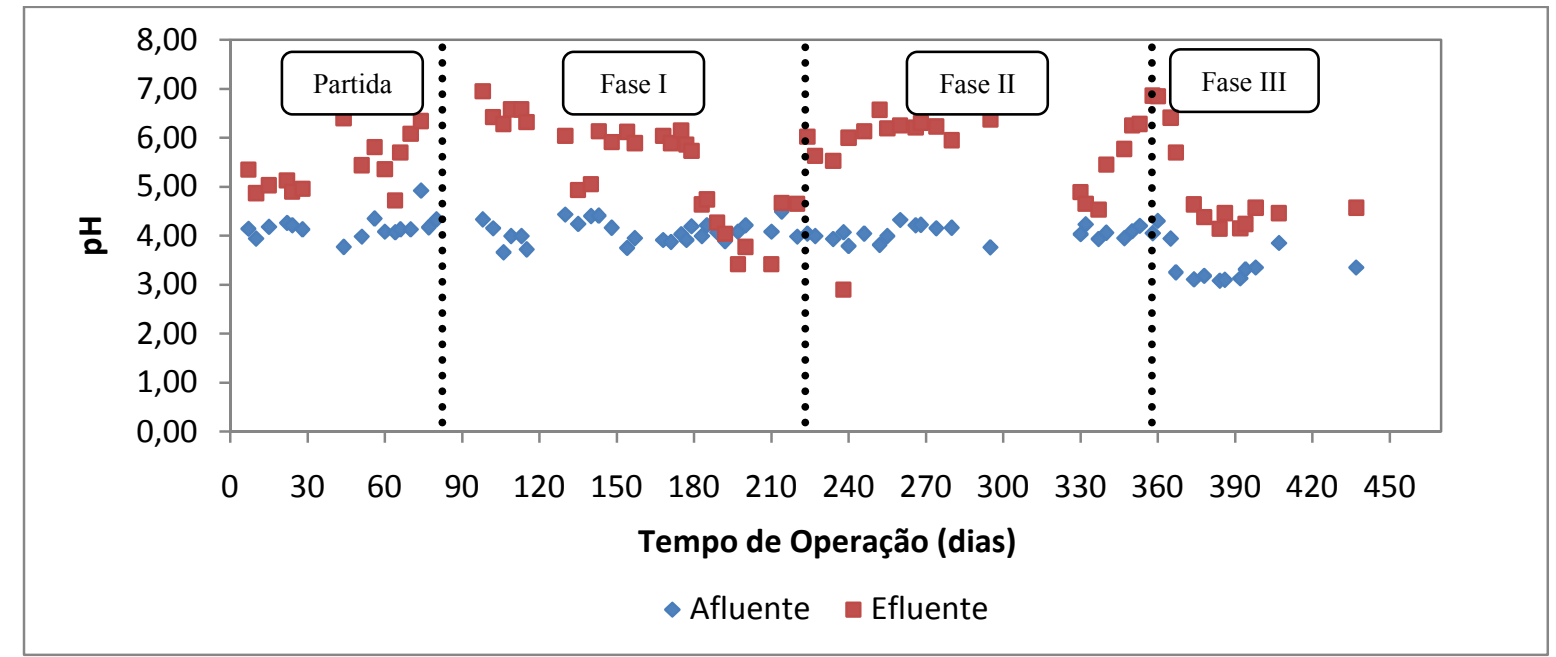

Figura 5.17. Variação do pH afluente ( $\bullet$ e efluente (๘) no RAHLF 3.

A operação do reator R3 contemplou três fases distintas, além da partida do reator. Como este reator foi alimentado por um longo período, foi possível detectar visualmente o estabelecimento de certa estabilidade no reator, após 80 dias, aproximadamente. 
$\mathrm{O}$ aumento do $\mathrm{pH}$ efluente neste reator foi bastante significativo nas fases I e II, com valores entre 6,0 e 7,0, muito superiores ao $\mathrm{pH}$ afluente, que com a diluição estava próximo a 4,00. Durante essas duas fases foram obtidos os melhores valores de eficiência desse reator e, portanto, o grande consumo de íons sulfato $\mathrm{e}^{+}$observado refletiram-se diretamente no $\mathrm{pH}$ do efluente do reator. A queda no $\mathrm{pH}$ observada ao final da fase I deveu-se a problemas operacionais como trincas no reator e rompimento de mangueiras, que causaram certa instabilidade no sistema. O início da fase II, inclusive, foi direcionado por esses resultados, como uma alternativa de recuperação dos níveis satisfatórios que o reator vinha apresentando. Entretanto, os resultados da fase II mostraram que o aumento no aporte de elétrons (relação $\mathrm{DQO} / \mathrm{SO}_{4}{ }^{2-}$ igual a 1) na busca por um aumento na eficiência do reator não resultou em sucesso, visto que o reator manteve as mesmas características que vinha apresentando durante o melhor período da fase I. Provavelmente, se o reator tivesse se mantido por mais algum tempo na fase I, ele teria se recuperado e retomado os valores de eficiência. Esses resultados estão mais bem representados na análise das eficiências de remoção de DQO e sulfato.

O início da fase III (inserção da recirculação), pensada como uma resposta tecnológica a questão da diluição do afluente, provocou um colapso no sistema e resultou em queda acentuada no $\mathrm{pH}$ efluente para valores próximos a 4,5. Os problemas relacionados à recirculação serão discutidos amplamente com relação aos resultados de eficiência de remoção de DQO e sulfato.

Os resultados com relação ao comportamento da DQO afluente e efluente, juntamente com a eficiência de remoção da mesma obtida com o reator R3 estão mostrados na Figura 5.18

A utilização de um afluente diluído no reator R3, contendo apenas $25 \%$ da quantidade de sulfato encontrada na água de drenagem bruta favoreceu as altas remoções de etanol 
encontradas ao longo da operação na fase I. A diluição do afluente, além de reduzir a carga de sulfato aplicada a biomassa, também contribuía para um ligeiro aumento do $\mathrm{pH}$. Os dois fatores permitiram uma adaptação da biomassa às condições impostas.

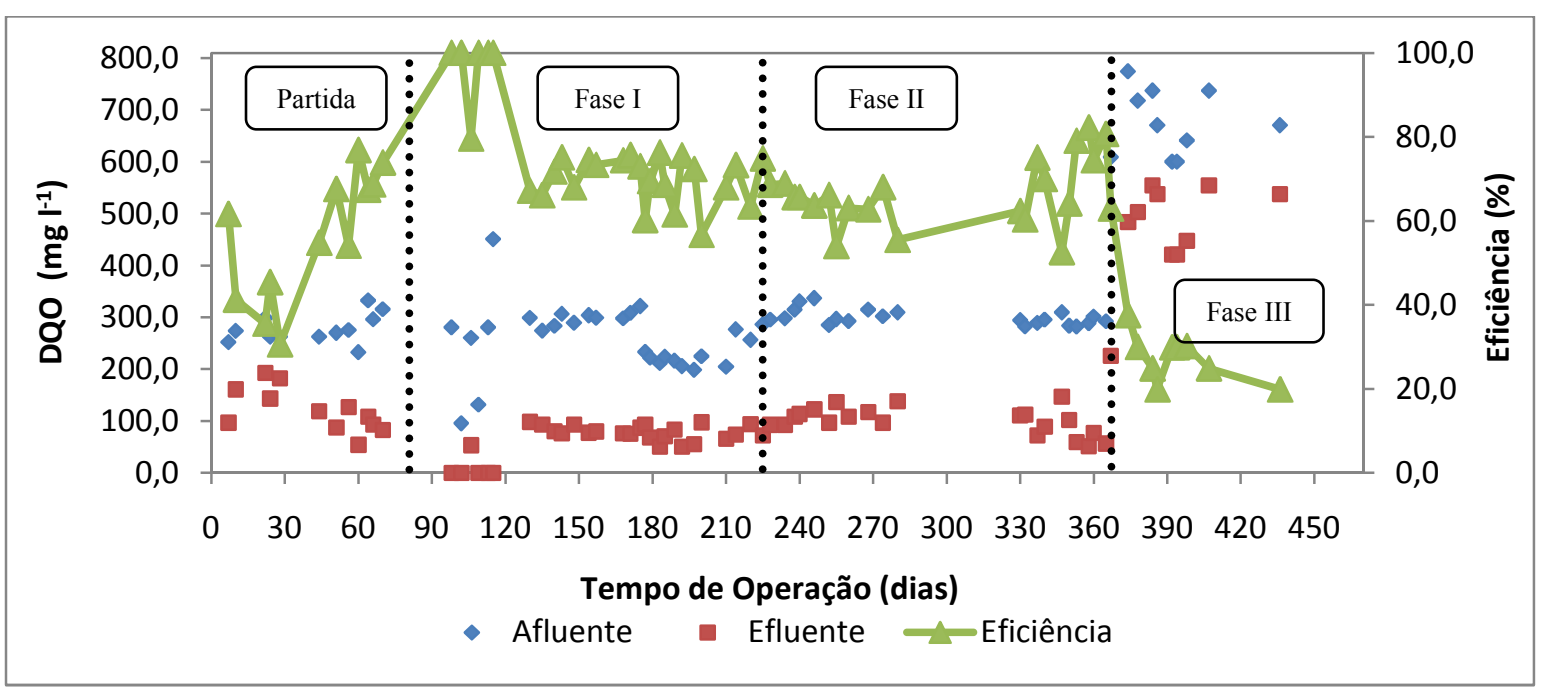

Figura 5.18. Variação da concentração de DQO afluente ( $\bullet$, efluente (ロ) e eficiência de remoção ( $\mathbf{\Delta})$ no RAHLF 3.

Kolmert e Johnson (2001) e Tsukamoto et al. (2004) afirmam em seus estudos que o tratamento de drenagem ácida por bactérias redutoras de sulfato não será totalmente efetivo sem um pequeno aumento do $\mathrm{pH}$ afluente. A Figura 5.12 mostra que nos primeiros 90 dias de operação do reator R3, a remoção da matéria orgânica foi instável e esse período poderia ser considerado a fase de partida do reator, até o estabelecimento de um regime permanente entre o $90^{\circ}$ e $180^{\circ}$ dia de operação (fase I). Nesse período de partida do reator, supõe-se que a biomassa competente para as condições estudadas foi selecionada e apenas aquelas capazes de utilizar sulfato como receptor final de elétrons e de sobreviver em $\mathrm{pH}$ ácido permaneceram no sistema.

Após a partida do reator, a eficiência em termos de remoção de DQO tornou-se elevada na fase I com resultados variando entre $60 \%$ e $80 \%$, alguns picos de $100 \%$ de 
remoção e média de $75,7 \% \pm 12,9 \%$. Nesse período, o reator parece ter encontrado as condições mais favoráveis ao seu funcionamento. Estima-se que a biomassa redutora de sulfato tenha se adaptado às condições rigorosas da água em estudo (pH ácido e alto conteúdo de metais) após cerca de 80 dias de operação do reator.

$\mathrm{Na}$ fase I, utilizou-se etanol na relação estequiométrica para a redução do sulfato. Porém, nem toda a matéria orgânica disponibilizada foi utilizada, o que certamente, impediu que a remoção do sulfato se desse por completo. A carga orgânica removida nessa fase foi de $0,19 \mathrm{~g} \mathrm{DQO}^{-1} \mathrm{dia}^{-1}$.

Na tentativa de melhorar a utilização da matéria orgânica para a redução de sulfato, visto que vinha sendo observada uma queda tanto no $\mathrm{pH}$ efluente quanto na eficiência de remoção de sulfato, optou-se por aumentar a quantidade de doadores de elétrons, para uma relação $\mathrm{DQO} / \mathrm{SO}_{4}{ }^{2-}$ próxima a 1,0 (fase II). Nesse período, a remoção média de DQO foi de $67,2 \% \pm 8,1 \%$ e a carga orgânica removida foi de $0,2 \mathrm{~g}$ DQO $1^{-1} \mathrm{dia}^{-1}$. Com o maior aporte de elétrons, não houve mudança na carga de DQO removida, porém a eficiência sofreu uma pequena queda e com isso uma maior quantidade de matéria orgânica estava presente no efluente do reator.

Observada a estabilidade da fase III, testou-se a inserção de recirculação do efluente como uma resposta tecnológica a questão da diluição do afluente, que vinha sendo realizada com água de abastecimento. Na fase III, entretanto, o reator entrou em colapso e a remoção de DQO sofreu queda brusca, com eficiência média de remoção de $27,4 \% \pm 5,7 \%$. A mudança do regime hidrodinâmico para um mais próximo de um reator de mistura, visto que a razão de recirculação era próxima de 3,0, poderia ter alterado o funcionamento da comunidade bacteriana que teria se estabelecido ao longo do reator com fluxo mais próximo do pistonado. Entretanto, é mais provável que o desequilíbrio no reator tenha sido provocado pela exposição 
dessa comunidade presente na porção inicial aos produtos intermediários, principalmente o sulfeto, oriundos do efluente tratado.

A Figura 5.19 apresenta os dados de concentração de ácido acético obtidos ao longo da operação do reator R3.

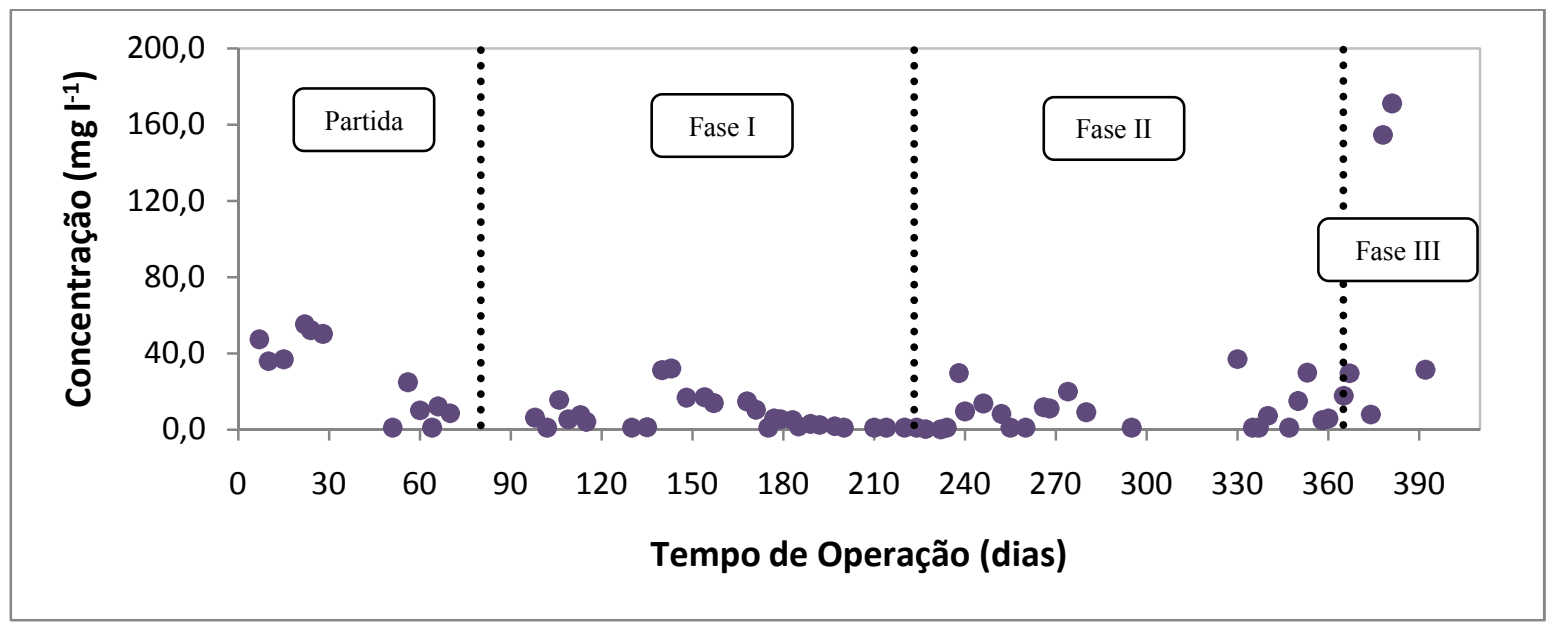

Figura 5.19. Variação na concentração de ácido acético (efluente - afluente) no reator R3.

Como esperado, notou-se pouco acúmulo de ácido acético no efluente durante as fases I e II desse reator. Como observado no reator R2, a redução na carga de sulfato aplicada parece direcionar o metabolismo das redutoras de sulfato a uma oxidação completa da matéria orgânica, com menor geração de ácido acético. Durante a fase I, a carga média de ácido acético efluente foi de $12,7 \mathrm{mg}$ acetato $\mathrm{l}^{-1} \mathrm{dia}^{-1}$, enquanto na fase II notou-se ligeiro aumento para 20,0 mg acetato $\mathrm{l}^{-1} \mathrm{dia}^{-1}$. Esse aumento na concentração de ácido acético pode ser resultado do maior aporte de elétrons oferecido neste período, visto que com maior quantidade de etanol disponível, a biomassa utilizaria primeiro a energia resultante da oxidação parcial e, então, oxidaria o acetato a $\mathrm{CO}_{2}$ e $\mathrm{H}_{2} \mathrm{O}$.

Com o início da fase III, foram detectadas grandes quantidades de ácido acético no efluente. Nessa fase, o reator já não conseguia mais se manter estável e é provável que o 
acúmulo de ácidos tenha, inclusive, favorecido esse desequilíbrio. A maior geração de acetato pode resultar de uma desestruturação na biomassa gerada pela inserção de recirculação e maior aporte de compostos tóxicos, principalmente sulfeto, à biomassa existente na porção inicial do reator.

A Figura 5.20 apresenta os resultados de remoção de sulfato ao longo dos 450 dias de operação do reator R3.

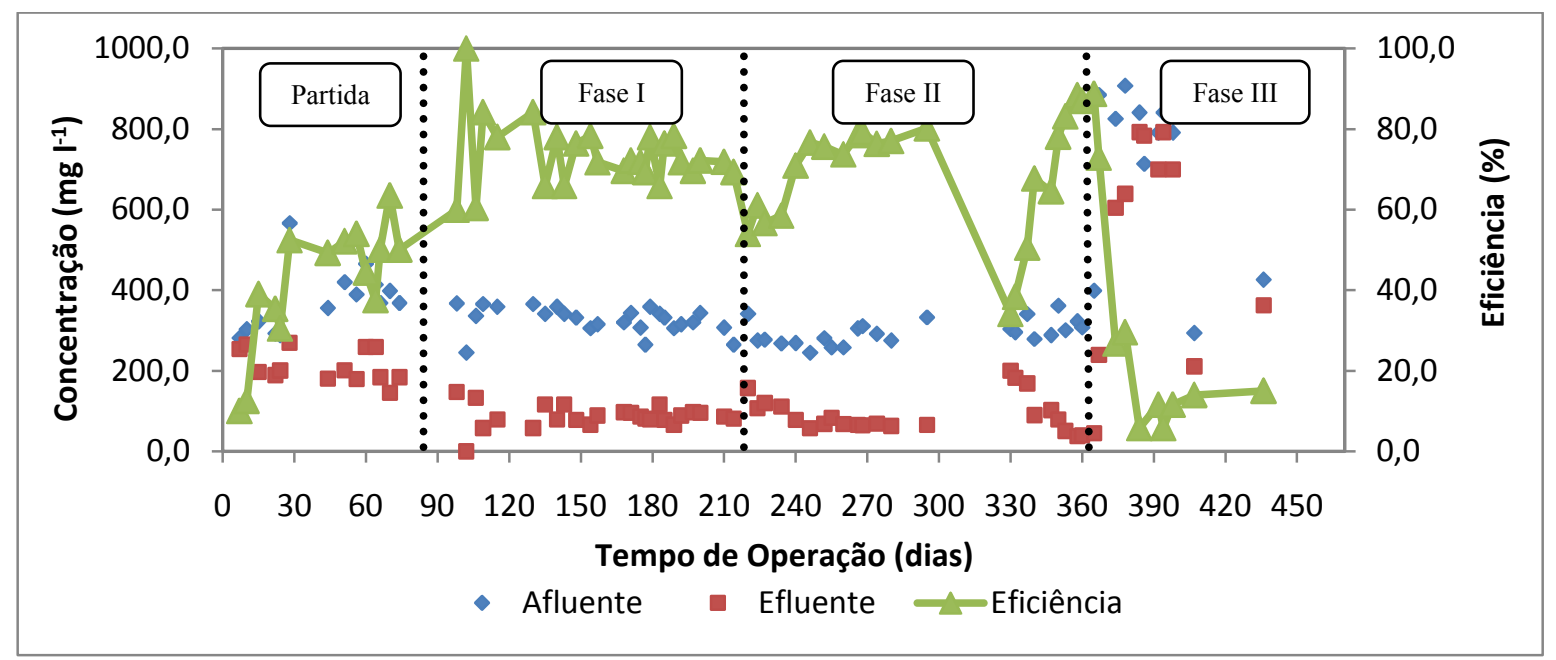

Figura 5.20. Variação da concentração de sulfato afluente ( $\bullet$ ), efluente (ロ) e eficiência de remoção ( $\mathbf{\Delta})$ no RAHLF 3.

$\mathrm{O}$ comportamento do reator R3 quanto a remoção de sulfato foi semelhante àquele observado na remoção de DQO. Durante 90 dias, o reator apresentou-se muito instável, com remoções que variaram de 10 a $60 \%$. Após esse período, a remoção de sulfato ficou bastante estável na fase I, quando a relação $\mathrm{DQO} / \mathrm{SO}_{4}{ }^{2-}$ adotada foi de 0,67 . Durante essa fase, a remoção média foi de $72,8 \% \pm 9,0 \%$, com uma carga de sulfato removida média de $0,24 \mathrm{~g}$ $\mathrm{SO}_{4}{ }^{2-} 1^{-1}$ dia $^{-1}$. Durante a fase II, com o aumento da relação $\mathrm{DQO} / \mathrm{SO}_{4}{ }^{2-}$ para 1,0 , não foi possível identificar uma mudança expressiva nas características do reator. A remoção média 
de sulfato foi de $74,5 \% \pm 9,4 \%$ com uma carga média de sulfato removida de $0,24 \mathrm{~g} \mathrm{SO}_{4}{ }^{2-} \mathrm{l}^{-1}$ dia $^{-1}$. Durante a fase III, nota-se queda acentuada da remoção média para $15,0 \% \pm 8,8 \%$.

A diminuição da carga de sulfato aplicada ao sistema foi um parâmetro determinante na melhora da eficiência da remoção de sulfato da drenagem ácida de mina. Entretanto, o aumento da relação $\mathrm{DQO} / \mathrm{SO}_{4}{ }^{2-}$ não favoreceu o sistema redutor de sulfato como se imaginava inicialmente.

A queda na eficiência de remoção de sulfato observada entre o $300^{\circ}$ e o $330^{\circ}$ dias de operação deve-se a um problema de rompimento da parede do reator, cujo conserto tomou certo tempo, o que desestabilizou ligeiramente o processo sulfetogênico. É visível que a redução do sulfato nas condições estudadas foi mais facilmente afetada por problemas operacionais do que a remoção da DQO, como pode ser notada na Figura 5.12. É provável que, mesmo após longo período de operação, a comunidade microbiana ainda apresentasse alta diversidade e, em determinadas situações que desfavoreceriam as redutoras de sulfato, outros microrganismos menos exigentes poderiam utilizar da matéria orgânica disponível. Exames de microscopia também indicaram a presença de bactérias com morfologia semelhantes a fermentativas na biomassa retirada do reator R3, como pode ser visto pela Figura 5.21. 


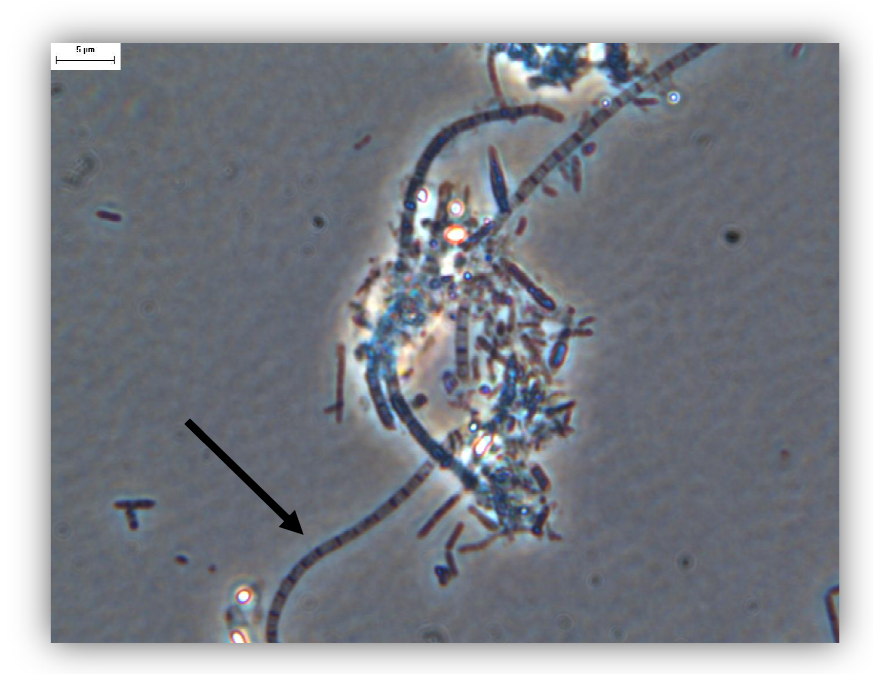

Figura 5.21. Imagem de microscopia de contraste de fase do reator R3. Bactérias com morfologia semelhante a bactérias fermentativas.

Os resultados obtidos no reator R3 confirmam a presença de uma biomassa mais adaptada que nos outros dois reatores, resultante da menor exposição dos microrganismos as condições extremas da água de drenagem ácida bruta (baixo pH, alta concentração de sulfato e de metais). A presença de uma biomassa adaptada foi essencial para conferir eficiências da ordem de $85 \%$ em um tratamento de drenagem ácida em reatores de coluna, como pode ser visto nos resultados de Jong e Parry (2003). A escolha de um inóculo de BRS para aderência ao material suporte do reator permitiu que o $\mathrm{pH}$ do afluente que era 4,5 passasse a 7,2 no efluente com um tempo de detenção hidráulica de 16 horas. Kolmert e Johnson (2001) também obtiveram melhores reduções de sulfato de águas ácidas nos reatores inoculados com cultura acidofílica na presença do etanol utilizando uma relação $\mathrm{DQO} / \mathrm{SO}_{4}{ }^{2-}$ de $1,0$.

A eficiência na remoção de sulfato no caso de águas de drenagem ácida de minas pode sofrer a influência significativa de dois fatores. $O$ primeiro deles diz respeito a velocidade de remoção de sulfato ser influenciada pela concentração de metais presentes no meio. Altas concentrações de metais podem resultar em uma diminuição no metabolismo das BRS, como descrito nos trabalhos de Song et al. (1998) e Sani et al. (2001). O segundo fator 
deve-se ao fato de que os sulfetos metálicos formados pela precipitação dos metais em solução quando em concentrações elevadas podem bloquear os poros do material suporte e desfavorecer os fenômenos de transporte de massa.

A Figura 5.22 apresenta os resultados das análises de sulfeto efluente para o reator R3.

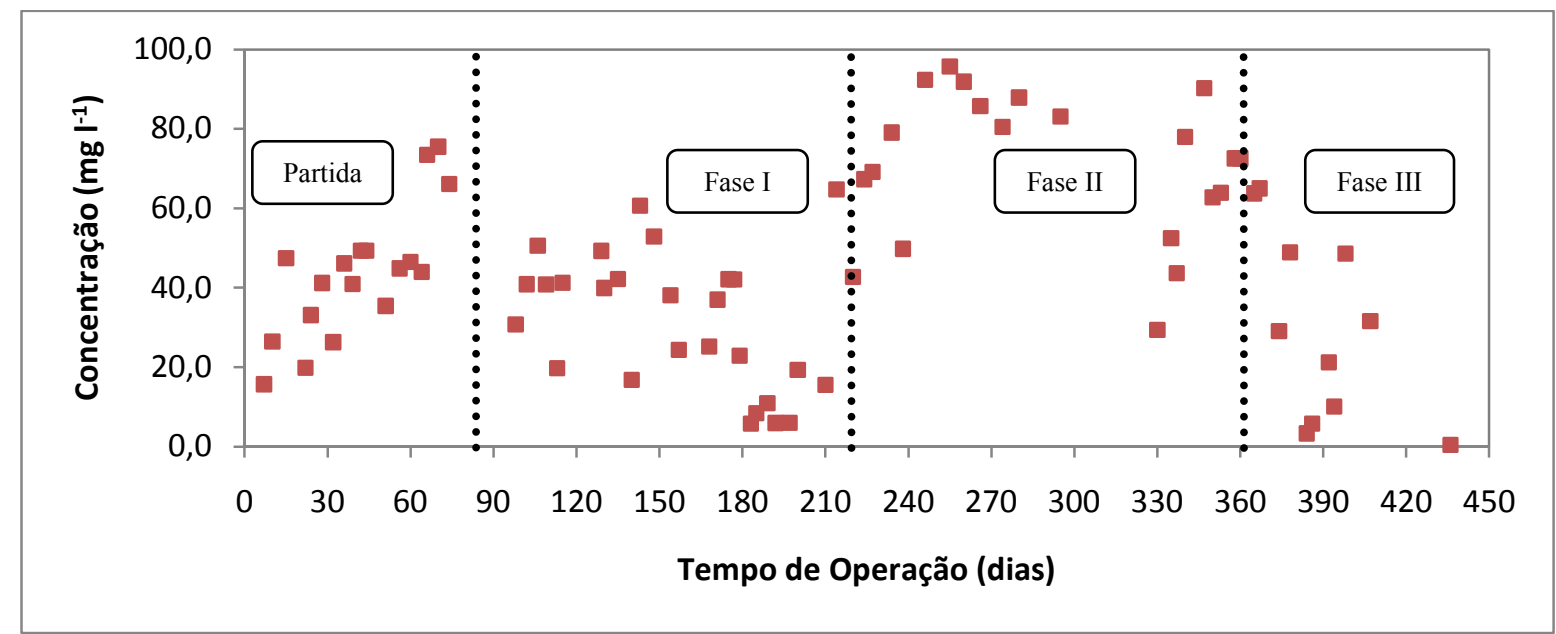

Figura 5.22. Variação da concentração de sulfeto efluente (घ) no RAHLF 3.

Como se pode observar, as concentrações de sulfeto determinadas no efluente foram muito instáveis e não representaram necessariamente o comportamento da remoção de sulfato observada. Foram utilizadas, todavia, como indicativas da sulfetogênese. Especialmente no reator R3, pode-se observar que ao final da fase II, as concentrações de sulfeto estavam próximas de $80 \mathrm{mg} \mathrm{l}^{-1}$ e, com o início da recirculação do efluente tratado, parte desse sulfeto foi levado ao início do reator, o que pode ter sido o grande responsável pelo desequilíbrio nessa fase do reator.

O sulfeto de hidrogênio pode afetar o funcionamento de coenzimas e desnaturar proteínas por precipitar metais em sítios ativos de ambas. Também pode afetar a assimilação do enxofre e o $\mathrm{pH}$ intracelular. Adicionalmente, pode diminuir a biodisponibilidade de metais 
essenciais ao metabolismo bacteriano. A toxicidade do sulfeto em BRS está muito relacionada às espécies bacterianas presentes. Maillacheruvu e Parkin (1996) estudaram BRS oxidadoras de propionato, acetato e as hidrogenotróficas e reportaram que as acetototróficas foram muito mais sensíveis a toxicidade por sulfeto. De maneira semelhante, Yamaguchi et al. (1999) sugerem que as oxidadoras de acetato foram mais susceptíveis a toxicidade do que as BRS hidrogenotróficas. Entretanto, Kaksonen et al. (2004) descrevem que a oxidação do etanol foi mais afetada pelo presença de sulfeto do que a oxidação do acetato.

$\mathrm{Na}$ fase I do reator R3, a concentração média de sulfeto analisada no efluente foi $32,0 \pm 17,0 \mathrm{mg} \mathrm{l}^{-1}$, enquanto na fase II, a média foi de $75,8 \pm 19,3 \mathrm{mg} \mathrm{l}^{-1}$ e na fase III, de $29,8 \pm 23,9 \mathrm{mg} \mathrm{l}^{-1}$. Somente na fase II, a concentração de sulfeto determinada esteve próximo da esperada em função do sulfato removida $\left(245,0 \mathrm{mg} \mathrm{l}^{-1}\right)$. Esses resultados refletiram a dificuldade dessa análise quando se trabalha em $\mathrm{pH}$ ácido e todo o sulfeto está praticamente na fase gasosa.

No caso dos reatores estudados, as concentrações de sulfeto determinadas estiveram, na maioria das vezes, abaixo da concentração estequiométrica esperada em função do sulfato reduzido em cada etapa. Três possíveis aspectos poderiam ser responsáveis por esta diferença: (i) a perda de sulfeto para a atmosfera, uma vez que se trata de um composto de natureza volátil no $\mathrm{pH}$ estudado, que pode ter sido perdido mesmo com sua análise sendo conduzida imediatamente após a coleta da amostra; (ii) a reação para formação de outros compostos de enxofre, como o enxofre elementar, que poderia ser formado por oxidação do sulfeto por moléculas de oxigênio que permeariam a mangueira de silicone acoplada à saída de gases do reator; (iii) e a precipitação na forma de sulfetos metálicos. Dentre esses, a volatilização do sulfeto e a formação de precipitados são processos que apresentam notável dependência do pH da solução. Em uma solução ácida espera-se maior volatilização do sulfeto e menor formação de sulfetos metálicos, devido ao deslocamento do equilíbrio das espécies $\mathrm{H}_{2} \mathrm{~S}, \mathrm{HS}^{-}$e 
$\mathrm{S}^{2-}$ para a formação de $\mathrm{H}_{2} \mathrm{~S}$, em detrimento das espécies iônicas. Porém, em um pH de 6,4, segundo a especiação do sulfeto, cerca de $50 \%$ das espécies seria HS .

Kaksonen e Puhakka (2007) apresentam uma revisão de trabalhos que sugerem pH ótimos de precipitação para diferentes metais como sulfetos ou hidróxidos, muitos deles presentes na água residuária em estudo. De acordo com o diagrama da Figura 5.23, dentro da faixa de $\mathrm{pH}$ obtida durante a operação dos reatores RAHLF, para a drenagem estudada poderse-ia esperar a precipitação, principalmente, de $\mathrm{Cu}, \mathrm{Cd}, \mathrm{Zn}, \mathrm{Fe}(\mathrm{III})$, com pouca precipitação de Fe(II), Ni e Mn.

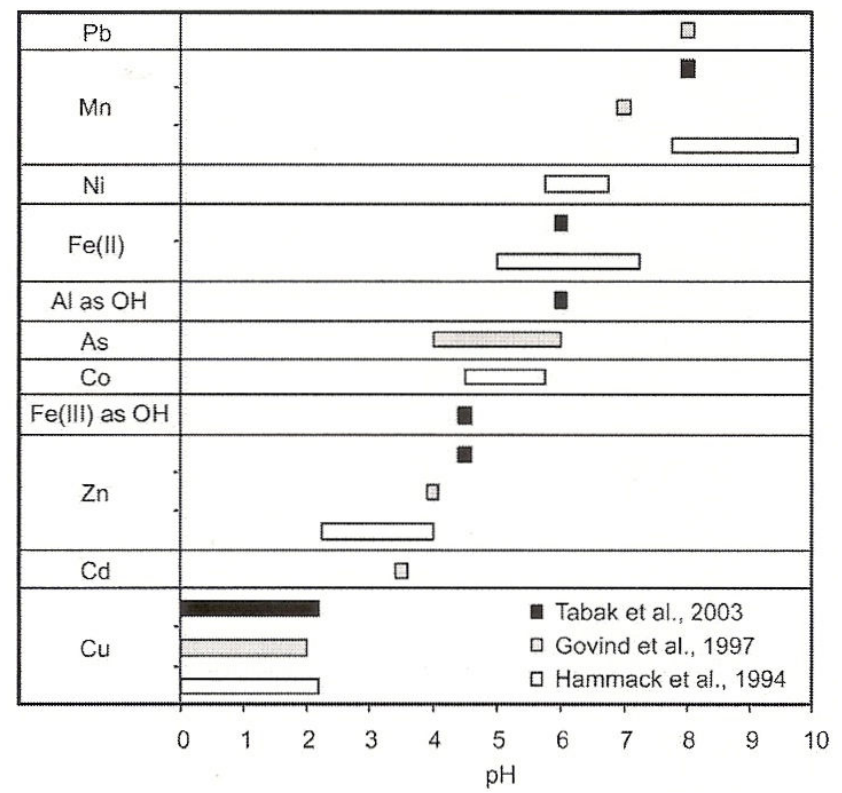

Figura 5.23. pH recomendado para a precipitação de metais como sulfetos ou hidróxidos.

Jong e Parry (2003), que estudaram a remoção de sulfato e metais de águas ácidas em reatores de leito fixo, também relataram tais dificuldades em quantificar todas as espécies de enxofre, fechando o balanço de massa deste elemento. Os autores, contudo, relatam que o enxofre utilizado na precipitação de metais correspondeu apenas a 3,5\% do total de enxofre de seu experimento. 
5.3.5 Análise Comparativa dos Reatores Anaeróbios Horizontais de Leito Fixo (pH, DQO, concentrações de ácido acético, de sulfato e de sulfeto).

A Tabela 5.6 mostra de forma comparativa os resultados obtidos com a operações dos reatores R1, R2 e R3 com relação ao pH efluente, a remoção de DQO e sulfato e a geração de ácido acético e sulfeto.

Tabela 5.6. Resultados das análises de monitoramento para os reatores R1, R2 e R3.

\begin{tabular}{|c|c|c|c|c|c|c|}
\hline Reator & Fase & $\begin{array}{c}\text { pH } \\
\text { Efluente }\end{array}$ & $\begin{array}{c}\text { Remoção de } \\
\text { DQO (\%) }\end{array}$ & $\begin{array}{l}\text { Ácido acético } \\
\left(\mathrm{mg} \mathrm{l}^{-1}\right)\end{array}$ & $\begin{array}{c}\text { Remoção de } \\
\mathrm{SO}_{4}{ }^{2-}(\%)\end{array}$ & $\begin{array}{l}\text { Sulfeto } \\
\left(\mathrm{mg} \mathrm{l}^{-1}\right)\end{array}$ \\
\hline \multirow{2}{*}{$\mathrm{R} 1$} & $\mathrm{I}$ & 4,3 & 32,1 & 208,0 & 17,3 & 39,0 \\
\hline & II & 4,1 & 25,0 & 10,0 & 13,8 & 27,4 \\
\hline \multirow{2}{*}{$\mathrm{R} 2$} & I & 7,0 & 37,8 & 240,0 & 18,4 & 30,9 \\
\hline & II & 5,8 & 65,0 & 11,0 & 40,6 & 44,7 \\
\hline \multirow{3}{*}{ R3 } & I & 7,0 & 75,7 & 3,0 & 72,8 & 32,0 \\
\hline & II & 6,8 & 67,2 & 7,0 & 74,5 & 75,8 \\
\hline & III & 4,6 & 27,4 & 143,0 & 15,0 & 29,8 \\
\hline
\end{tabular}

Com relação ao $\mathrm{pH}$ efluente, observou-se grande diferença entre as condições estudadas. No reator R1, a baixa eficiência quanto a remoção de sulfato e consequentemente, íons $\mathrm{H}^{+}$, resultou em pequena elevação do $\mathrm{pH}$ ao longo do reator. Os reatores $\mathrm{R} 2 \mathrm{e}$ R3, por sua vez, mostraram-se mais eficientes na remoção de acidez da drenagem ácida. O maior valor de pH no reator R2 na fase I foi resultado da correção do $\mathrm{pH}$ afluente para 5,0, o que de fato contribuiu para um maior $\mathrm{pH}$ efluente, quando comparado a fase seguinte. Para o reator R3, pouca diferença foi notada entre as fases I e II, com nenhuma influência sobre o pH quando oferecido um maior aporte de elétrons ao sistema. Nota-se, porém, a influência da redução da carga de sulfato imposta ao reator $\mathrm{R} 3$, que favoreceu o aumento do $\mathrm{pH}$ inicial e, como conseqüência, o pH efluente. 
O comportamento da remoção de DQO e sulfato apresentaram resultados semelhantes, no que diz respeito a resposta quanto as diferentes condições analisadas. Assim como na análise de $\mathrm{pH}$, o reator $\mathrm{R} 3$ foi o que apresentou melhor estabilidade no processo de remoção de sulfato e de etanol. Nas fases I e II do reator R3, as eficiências de remoção de DQO foram satisfatórias $(75,7 \%$ e $67,2 \%$, respectivamente), com pequena quantidade de DQO residual efluente $\left(78,8 \mathrm{mg} \mathrm{l}^{-1}\right.$ em média) e com pouco acúmulo de ácido acético no efluente. A diminuição da carga de sulfato aplicada nesse reator parece ter sido essencial para os bons resultados encontrados. O mesmo foi comprovado no reator $\mathrm{R} 2$, que sofreu uma expressiva melhora na eficiência da remoção de DQO quando da mudança na carga de sulfato aplicada (fase II). Entretanto, como a biomassa do reator R2 já havia sido exposta às condições mais extremas da drenagem bruta na fase I, a resposta do reator a redução da carga de sulfato aplicada foi menor do que no reator R3, que desde o início foi alimentado com drenagem diluída e menor carga de sulfato aplicada.

As análises de ácido acético indicaram que o acúmulo ocorreu, principalmente, em condições de maior instabilidade do reator (fase I do R1, fase I do R2 e fase III do R3). Mesmo para o reator R1, que na fase II tornou-se menos instável, apesar das baixas eficiências de remoção, a concentração de ácido acético foi reduzida a quase zero.

No caso dos reatores em estudo, o principal fator de influência foi a carga de sulfato aplicada que, quando reduzida a cerca de 1/3 daquela encontrada na drenagem bruta proporcionou remoções de sulfato da ordem de $70 \%$, com elevação do $\mathrm{pH}$ de 4,0 para 6,5 . A carga de sulfato aplicada foi um parâmetro muito mais importante do que o pH inicial, visto que no reator R2, a correção de pH não foi suficiente para favorecer a atuação das bactérias redutoras de sulfato, enquanto que após a mudança no regime de alimentação para um afluente diluído, rapidamente nota-se uma melhora significativa nas eficiências de remoção tanto de DQO quanto de sulfato. O aumento do aporte de elétrons no RAHLF não indicou ser 
necessário para melhora na eficiência do sistema, sendo que na relação $\mathrm{DQO} / \mathrm{SO}_{4}{ }^{2-}$ estequiométrica, o reator R3 apresentou os melhores resultados de eficiência de remoção de sulfato e matéria orgânica.

\subsubsection{Perfis espaciais de parâmetros nos RAHLF}

\subsubsection{Análise do perfil espacial do reator R1}

Foi realizado um perfil espacial a fase I deste reator, analisando-se os parâmetros de concentrações de DQO, sulfato, sulfeto, etanol e ácidos voláteis. Na fase II, não foi possível a realização de um perfil, visto que o reator se rompeu antes que fosse possível realizar a coleta de amostras.

A Figura 5.24 apresenta o comportamento da DQO, do sulfato e do sulfeto ao longo dos 7 pontos de amostragens do reator, sendo L/D igual a zero, o afluente e L/D igual a 20, o efluente. 


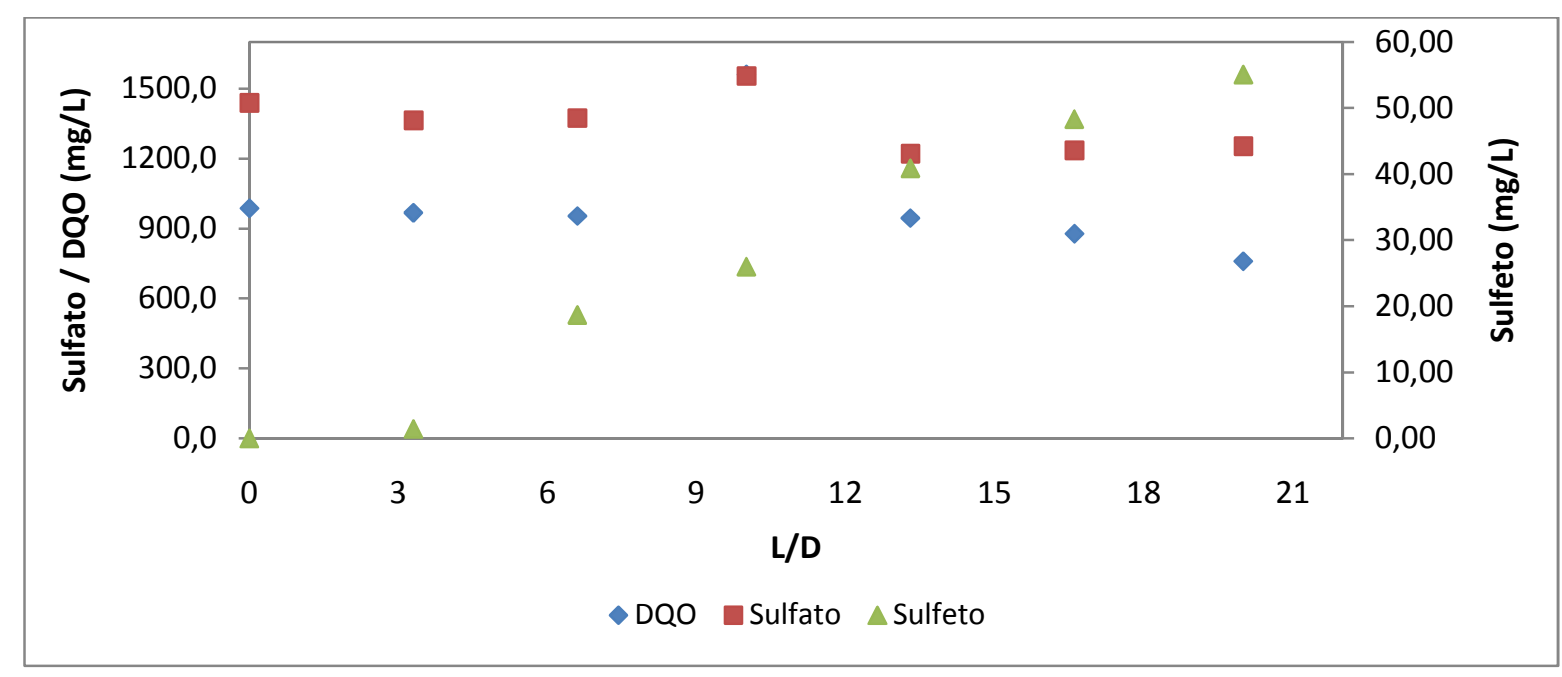

Figura 5.24. Variação da concentração de DQO, sulfato e sulfeto ao longo do leito do R1 na fase I.

Nota-se que, como analisado nos parâmetros de monitoramento, este reator não apresentou boas eficiências de remoção de DQO e sulfato. Percebe-se ligeira queda da DQO e do sulfato ao longo dos pontos de amostragem do reator, com um pico de aumento tanto de DQO como de concentração de sulfato em L/D igual a 10. Isso pode ser atribuído ao um descarte de material polimérico neste ponto, que teria contribuído para o aumento da DQO determinada, enquanto que para o sulfato, é possível que as vias de oxidação de sulfeto estivessem presentes no reator, como já discutido anteriormente.

Com relação ao sulfeto, este foi gerado a partir de L/D de 6,6 e apresentou tendência de crescimento até o final do reator. A concentração de sulfeto detectada esteve sempre abaixo da esperada estequiometricamente, provavelmente em função das dificuldades de análise mais precisas ou mesmo por conta da oxidação que parece ter ocorrido durante o escoamento ao longo do leito.

As análises da concentração de etanol e ácido acético (Figura 5.25) mostraram contínuo consumo do etanol a partir do primeiro amostrador (L/D de 3,3) até a saída do reator, com baixas concentrações detectadas no efluente $\left(25 \mathrm{mg} \mathrm{l}^{-1}\right)$. Enquanto para o ácido 
acético, notou-se crescente aumento na concentração, com acúmulo do mesmo ao longo do reator. Percebe-se que a DQO detectada na saída do reator deve-se basicamente a presença de acetato no efluente $\left(215 \mathrm{mg}\right.$ acetato $\left.\mathrm{1}^{-1}\right)$. Entre as duas medidas finais, observa-se ligeira redução na concentração de acetato, que poderia resultar de uma oxidação completa pelas BRS ou mesmo um consumo de acetato por outros grupos microbianos, o que parece ser o caso deste reator, visto que praticamente não foram detectados grupos de redutoras de sulfato nas análises de biologia molecular.

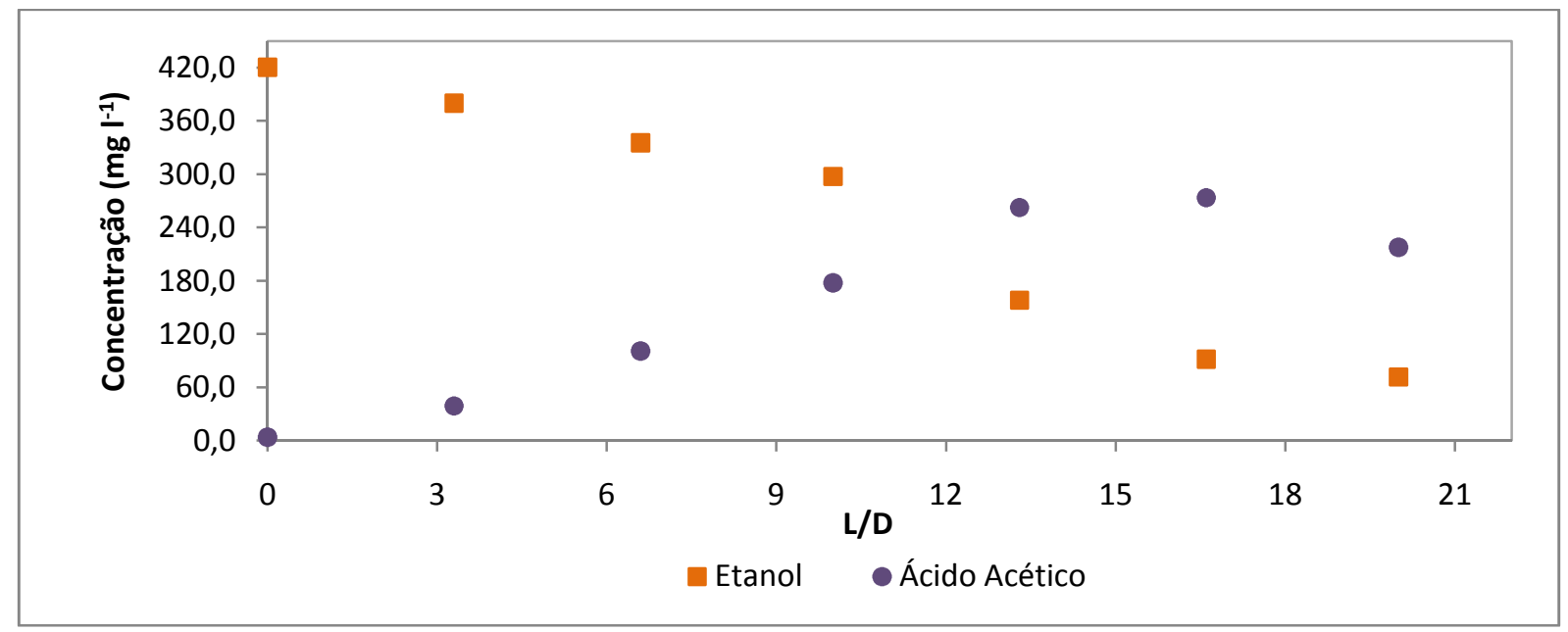

Figura 5.25. Variação da concentração de etanol e ácido acético no reator R1 na fase I.

\subsubsection{Análise dos perfis espaciais do reator R2}

Foram realizados perfis espaciais para as duas fases estudadas com determinação do pH e das concentrações de DQO, sulfato, sulfeto, etanol e ácidos voláteis.

Durante a fase I, o reator apresentou baixas eficiências de remoção de DQO $(37,8 \%)$ e de sulfato (18,4\%). A Figura 5.26 mostra que o pH sofreu contínuo aumento, indo de 5,5 até 
6,9 ao longo do leito do reator. Isso seria resultado, principalmente, do consumo de acidez gerado pela redução do sulfato.

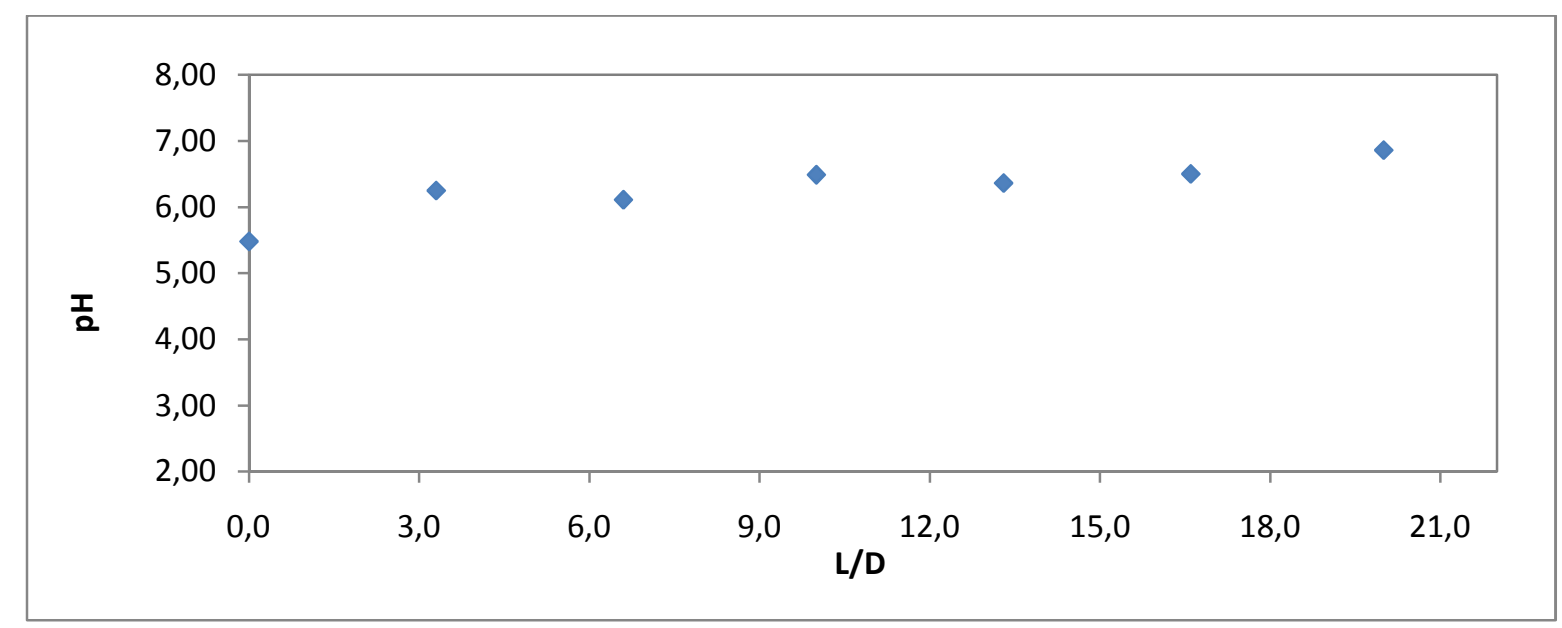

Figura 5.26. Comportamento do $\mathrm{pH}$ ao longo do leito do $\mathrm{R} 2$ na fase I.

O consumo da DQO e do sulfato também ocorreu de forma contínua ao longo do reator (Figura 5.27), com um ligeiro aumento na concentração de sulfato em L/D de 10, da mesma maneira que ocorreu para o reator R1. Acredita-se que neste caso também poderia estar ocorrendo uma oxidação de compostos reduzidos de enxofre. Inclusive, nesta fase, notase que entre L/D de 10 e 13,3, não há aumento no sulfeto produzido, enquanto há queda na concentração de sulfato. O sulfeto poderia estar precipitando os metais presentes na água residuária ou estar sendo oxidado a enxofre elementar, por exemplo. Com relação ao consumo de DQO, percebe-se que uma queda mais acentuada na concentração final do que para o sulfato. Acredita-se que, em função do $\mathrm{pH}$ mais próximo da neutralidade, neste reator estivessem presentes muitas comunidades capazes de utilizar o etanol como fonte de carbono e como doador de elétrons, sem utilizar, necessariamente, o sulfato como receptor final de elétrons. 


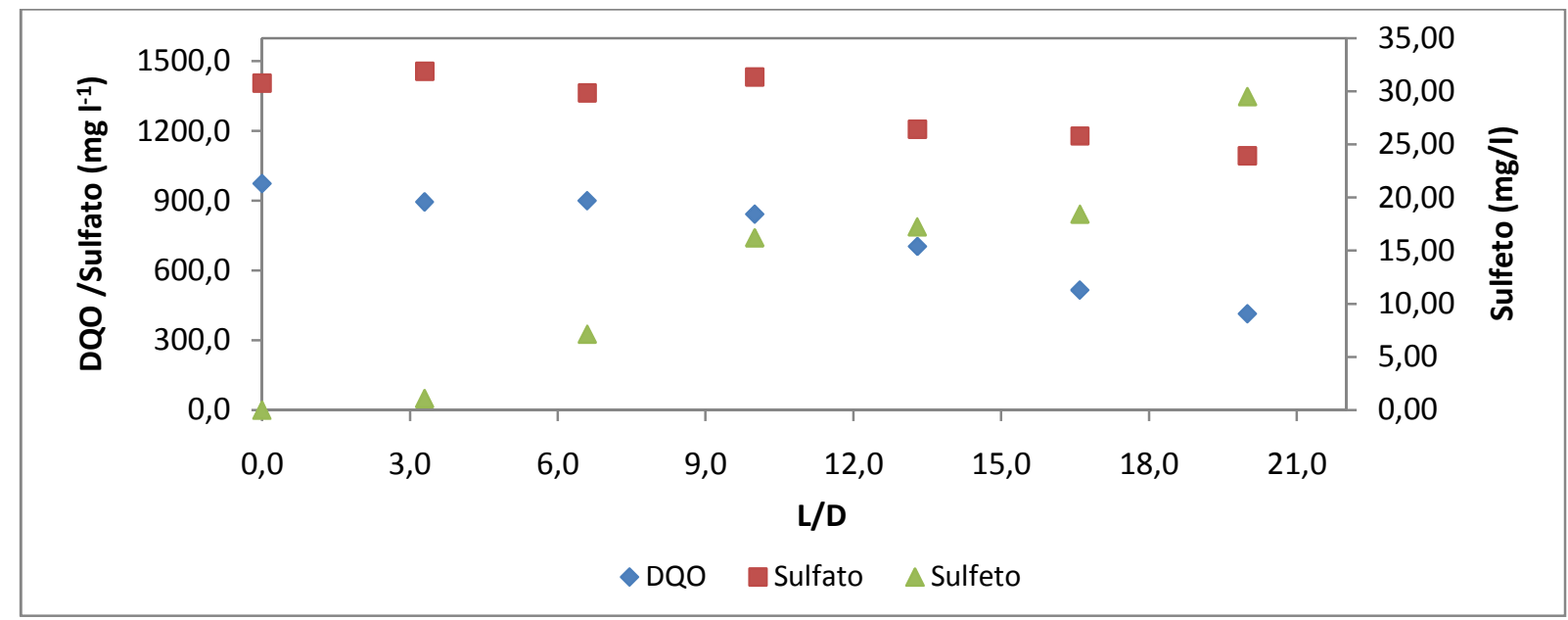

Figura 5.27. Variação da concentração de DQO, sulfato e sulfeto ao longo do reator R2 na fase I.

Com relação ao consumo de etanol e acúmulo de ácido acético (Figura 5.28), foi observado um comportamento semelhante ao reator R1. O etanol foi consumido de maneira contínua ao longo do reator, com baixas concentrações detectadas no efluente, enquanto o acetato foi gerado a partir de L/D de 3,3, acumulando-se ao longo do reator e sendo o principal responsável pela DQO residual no efluente. Notou-se novamente pequeno consumo de acetato entre os dois pontos finais de amostragem e isso pode ser atribuídos aos mesmos fatores discutidos para o reator R1. 


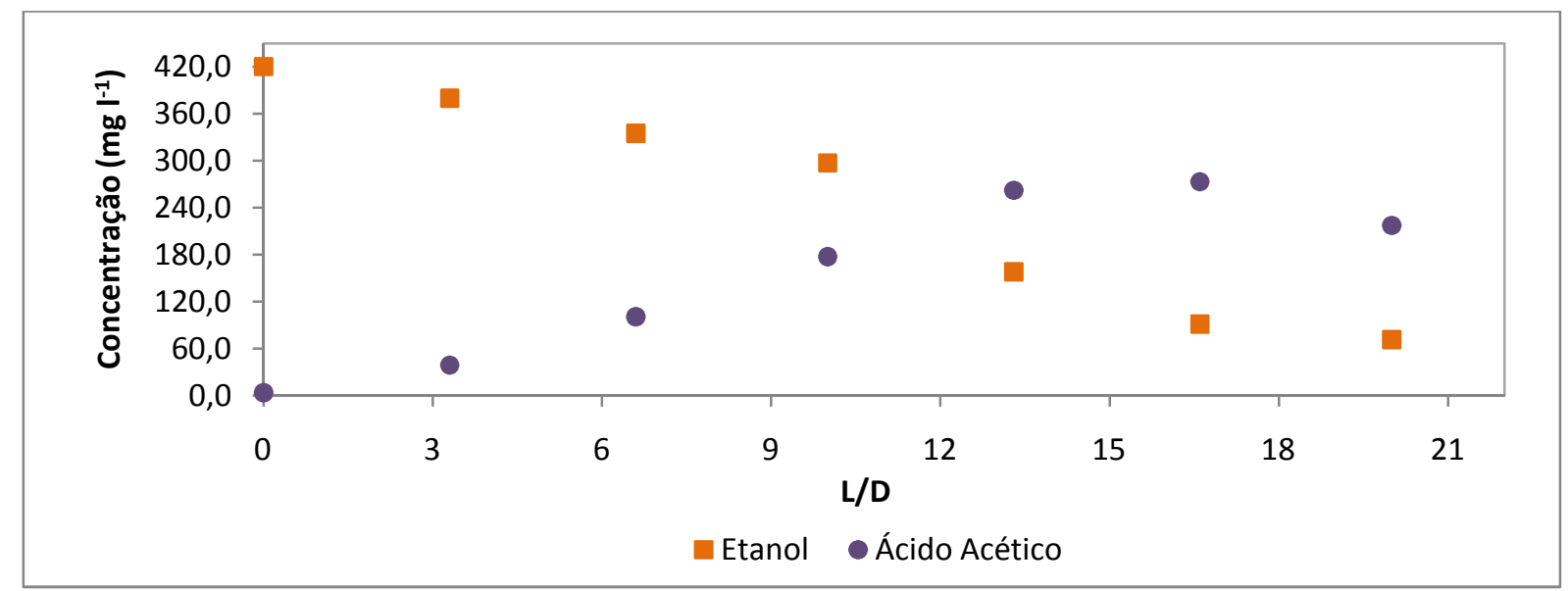

Figura 5.28. Variação da concentração de etanol e de ácido acético ao longo do reator R2 na fase I.

Ao final da fase II, o mesmo tipo de perfil espacial foi realizado no reator R2, com acompanhamento dos mesmos parâmetros analisados na fase I. O pH na fase II não era mais corrigido com adição de $\mathrm{NaOH}$, portanto, variou de 4,2 a 4,5 ao longo do reator R2 na fase II (Figura 5.29). Em L/D de 16,6, o pH ficou ligeiramente maior, em 5,5, porém sofreu queda entre esse ponto e o efluente. Não foi possível esclarecer esse comportamento, pois como mostrado adiante, ocorreu remoção de sulfato nessa porção do reator.

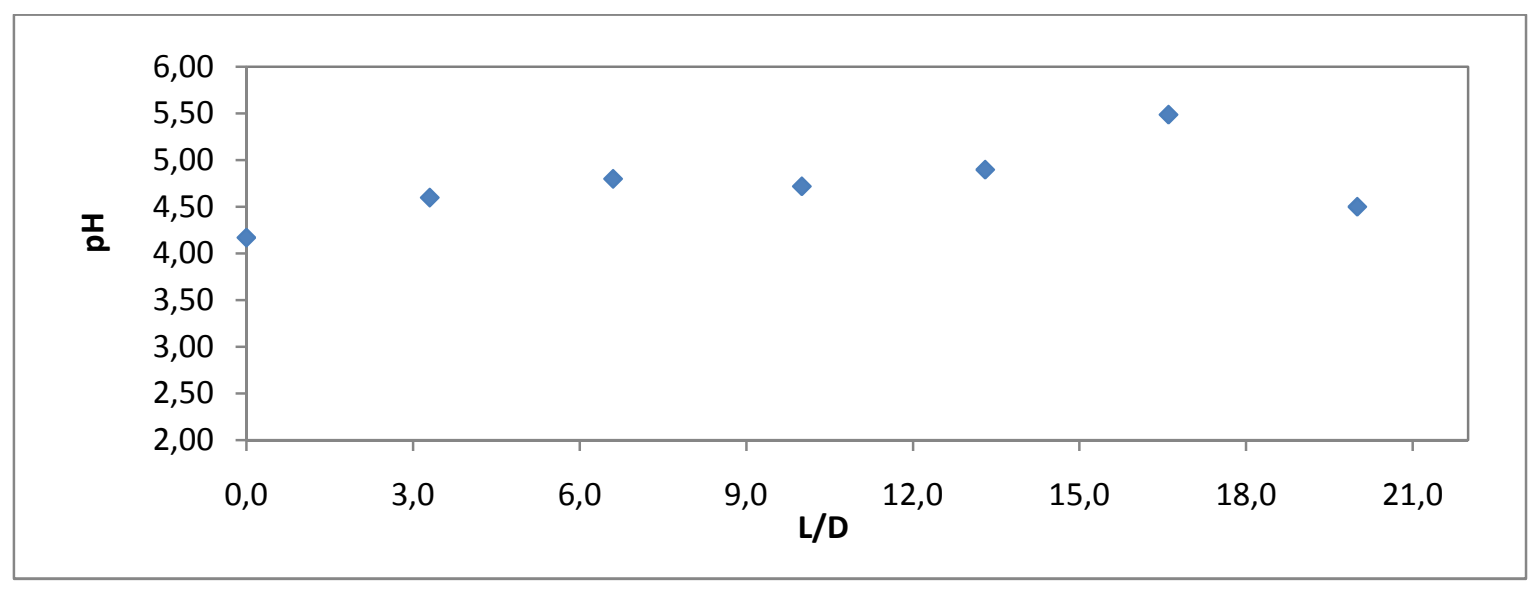

Figura 5.29. Variação do pH ao longo do leito do reator R2 na fase II. 
O consumo de sulfato na fase II deste reator foi bastante discreto entre o afluente e L/D de 6,6, como pode ser visualizado na Figura 5.30. A partir do ponto com L/D de 3,3, percebe-se um consumo maior de sulfato, porém com ligeiro aumento na concentração nos pontos de L/D de 13,3 e 16,6 e consumo acentuado na porção final do reator, resultando em uma eficiência de remoção de sulfato de $42,0 \%$. É possível que na porção final do leito deste reator, tenham se estabelecido comunidades mais especializadas em utilizar o sulfato como receptor de elétrons, possivelmente, em função do ligeiro aumento de pH nessa porção.

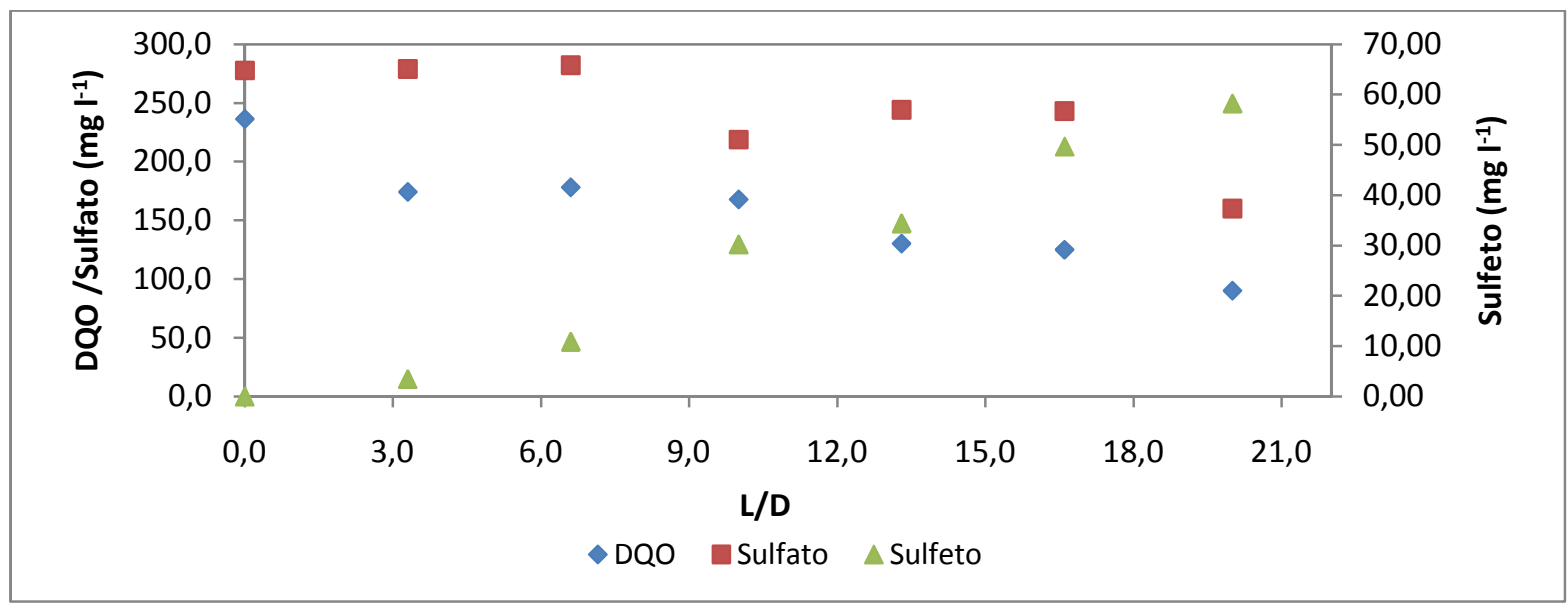

Figura 5.30. Variação nas concentrações de DQO, sulfato e sulfeto ao longo do reator R2 na fase II.

O consumo de etanol e a geração de ácido acético também foram avaliados nessa fase de operação do reator R2 (Figura 5.31). Notou-se um consumo acentuado de etanol nos três primeiros pontos de amostragem, com redução de $84 \%$ do etanol adicionado até L/D de 10 . Entretanto, até o $3^{\circ}$ ponto de amostragem não foi notada redução significativa do sulfato, como mostrado na Figura 5.30. O etanol removido até este ponto pode ter sido utilizado por outros grupos bacterianos, diferentes das redutoras de sulfato ou, se essas o utilizavam, estavam transferindo os elétrons a um receptor diferente do sulfato. Acetato foi produzido ao longo do leito até L/D de 10, sendo consumido a partir dessa porção até a saída do reator. 
Uma possibilidade, nesse caso, seria a utilização de acetato por bactérias redutoras completas, já que a partir do $4^{\circ}$ ponto de amostragem iniciou-se a redução do sulfato presente no reator. Como discutido na análise de monitoramento, a redução da carga de sulfato aplicada aos reatores R2 (fase II) e R3 (fases I e II) foi responsável por permitir a utilização completa da matéria orgânica, com detecção quase nula de acetato no efluente. Esse comportamento seria característico de bactérias redutoras capazes de oxidar completamente o acetato.

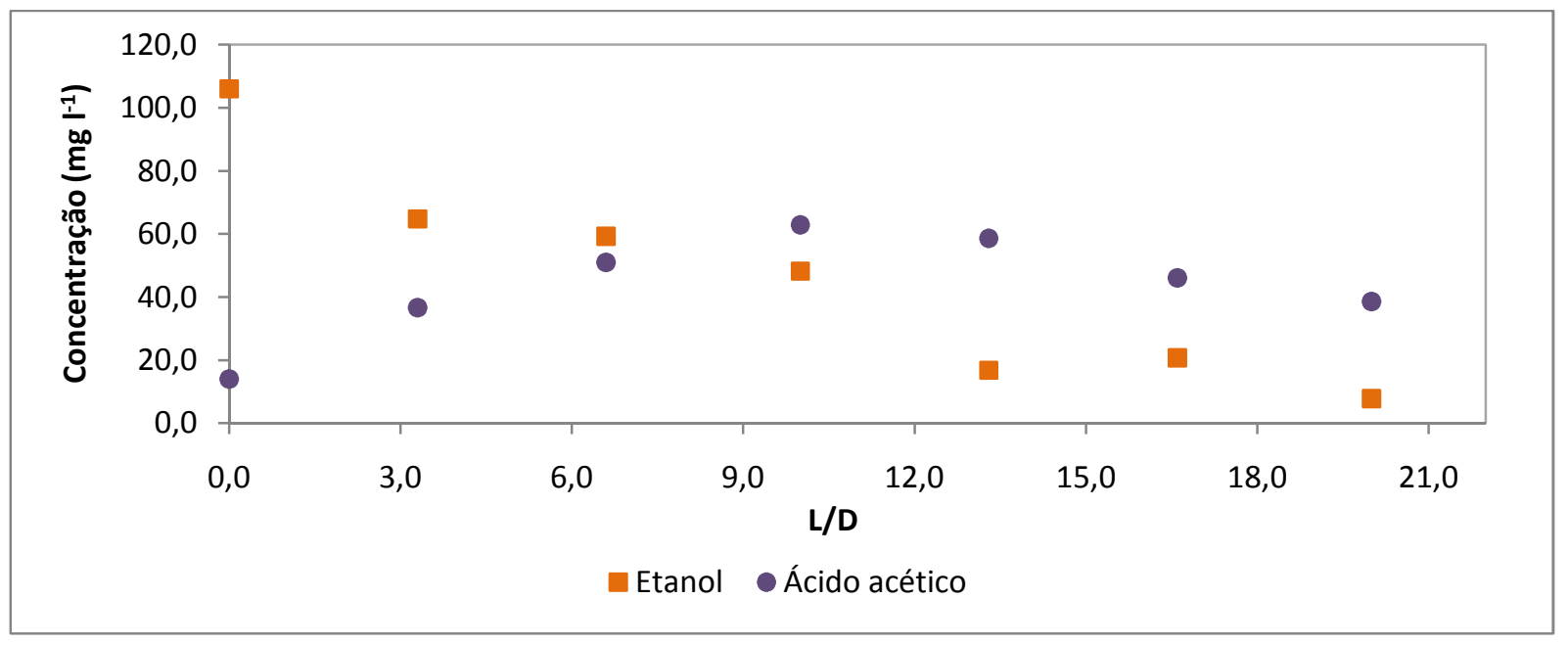

Figura 5.31. Variação das concentrações de etanol e ácido acético ao longo do reator R2 na fase II.

\subsubsection{Análise dos perfis espaciais do reator R3}

O gráfico de $\mathrm{pH}$ na fase I deste reator (Figura 5.32) mostra um aumento praticamente contínuo dos valores de $\mathrm{pH}$, saindo de 4,2 até 5,4, um indicativo de que estava ocorrendo consumo de acidez neste reator. 


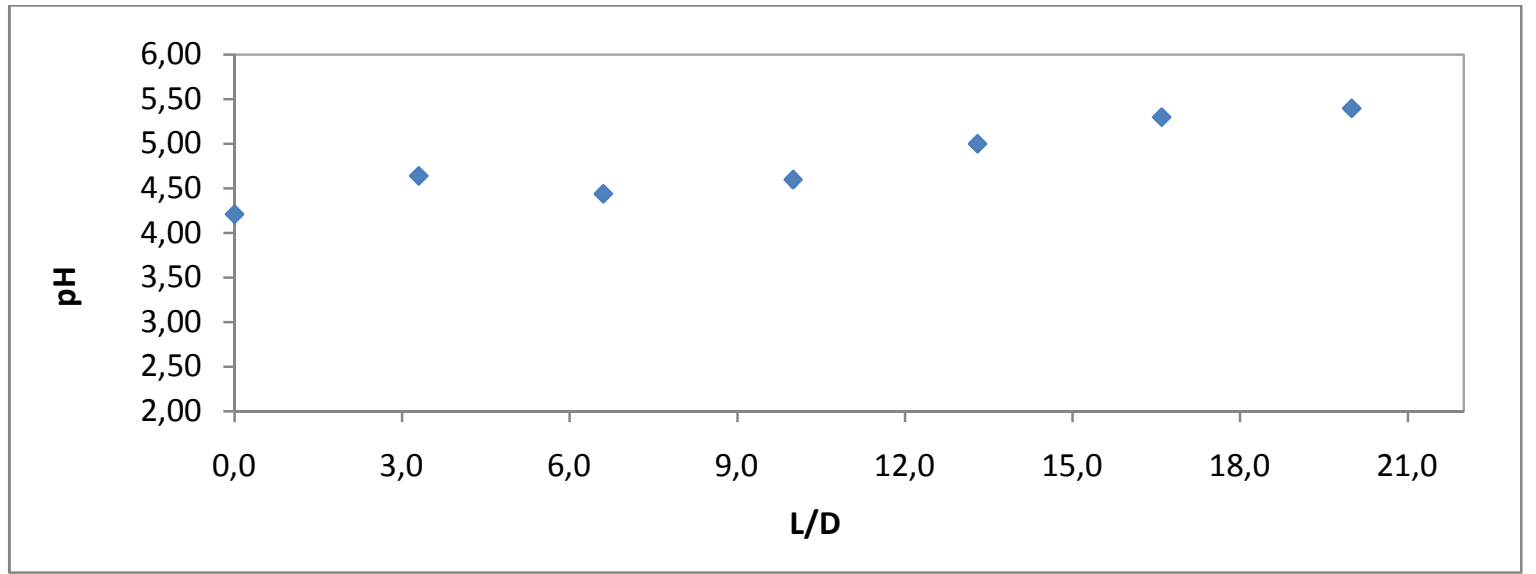

Figura 5.32. Variação do pH ao longo do reator R3 na fase I.

O consumo da DQO e de sulfato também foi avaliado, juntamente com a produção de sulfeto, como pode ser visualizado na Figura 5.33.

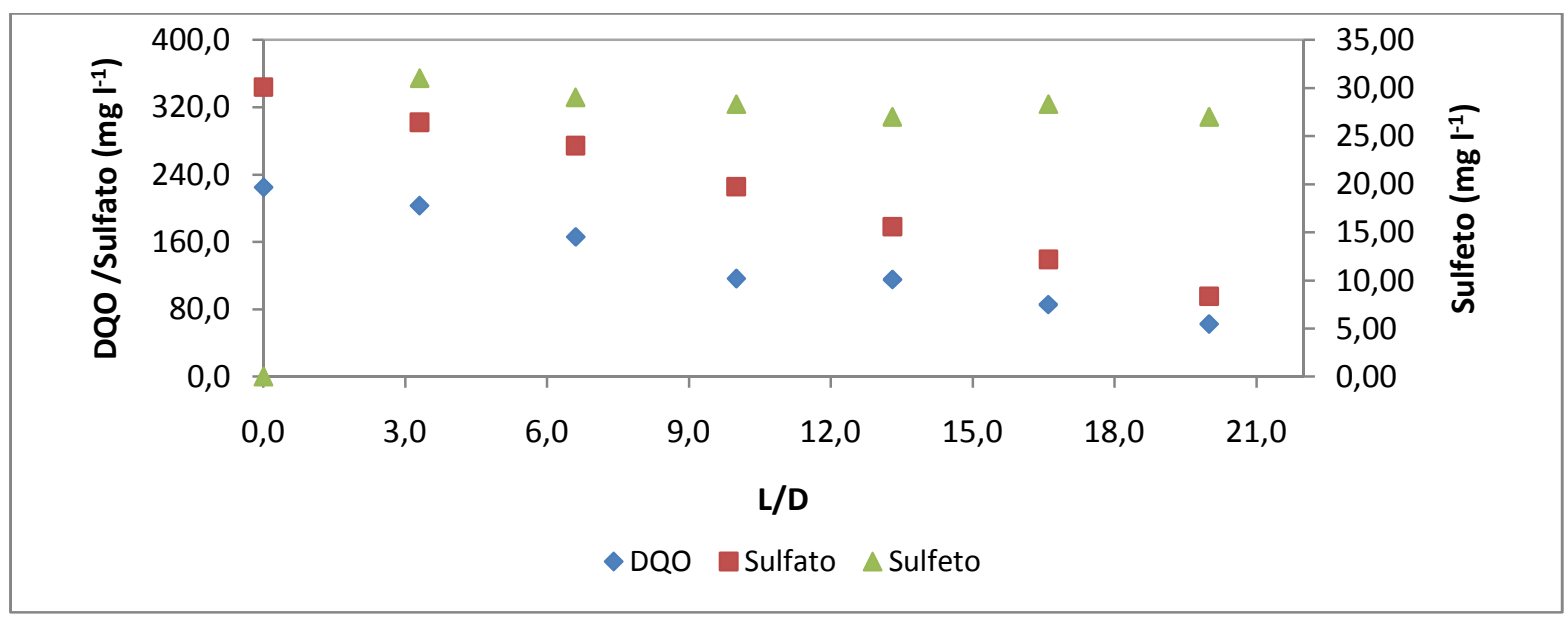

Figura 5.33. Variação nas concentrações de DQO, sulfato e sulfeto ao longo do reator R3 na fase I.

Tanto a DQO quanto o sulfato foram consumidos ao longo de todo o leito do reator, indicando a necessidade do TDH empregado nesses estudos, que foi de $24 \mathrm{~h}$. A comunidade microbiana deste reator, que foi o reator com melhores eficiências de operação, parecia estar bem distribuída ao longo de todo o leito. A geração de sulfeto, entretanto, atingiu o pico no $2^{\circ}$ ponto de amostragem e não sofreu mais alteração até a saída do reator. Essa dificuldade de 
análise do gás sulfídrico já foi apresentada anteriormente e dificultou o fechamento do balanço de enxofre nos reatores estudados.

Também como para os outros reatores, avaliou-se o consumo de etanol e a geração de ácido acético, como mostrado na Figura 5.34.

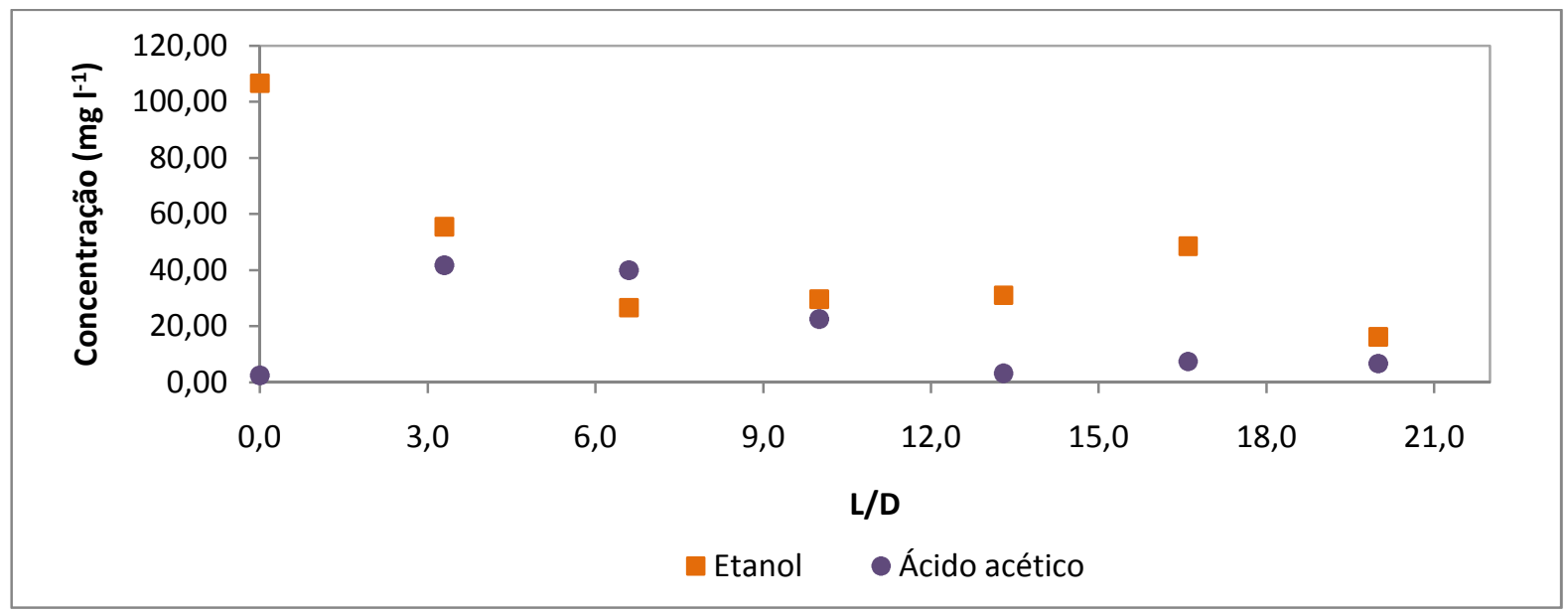

Figura 5.34. Variação das concentrações de etanol e ácido acético ao longo do reator R3 na fase I.

O consumo de etanol se deu de maneira mais intensa entre o afluente e L/D de 3,3, com variações ao longo do restante do leito. Entre L/D de 3,3 e 6,6, notou-se também a maior geração de ácido acético, que foi consumido ao longos do leito do reator, resultando em concentrações efluentes bem diminutas, como mostrados nos dados de monitoramento desse reator. Esses dados deram indicativos da presença de redutoras de sulfato completas que oxidam o acetato a gás carbônico e água. Entretanto, é possível que a geração de acetato tenha ocorrido por oxidação incompleta da matéria orgânica mediada por redutoras de sulfato incompletas. De qualquer maneira, mesmo que existisse um consumo de DQO por outros grupos bacterianos, o reator R3 apresentava características sulfetogênicas muito bem estabelecidas. 
Durante a fase II, realizou-se um segundo perfil, agora com o reator operando com a relação $\mathrm{DQO} / \mathrm{SO}_{4}{ }^{2-}$ de 1,0 .

O comportamento do $\mathrm{pH}$, mostrado na Figura 5.35, foi semelhante, porém com um $\mathrm{pH}$ final elevado do que na fase I (5,4 na fase I e 6,5 na fase II).

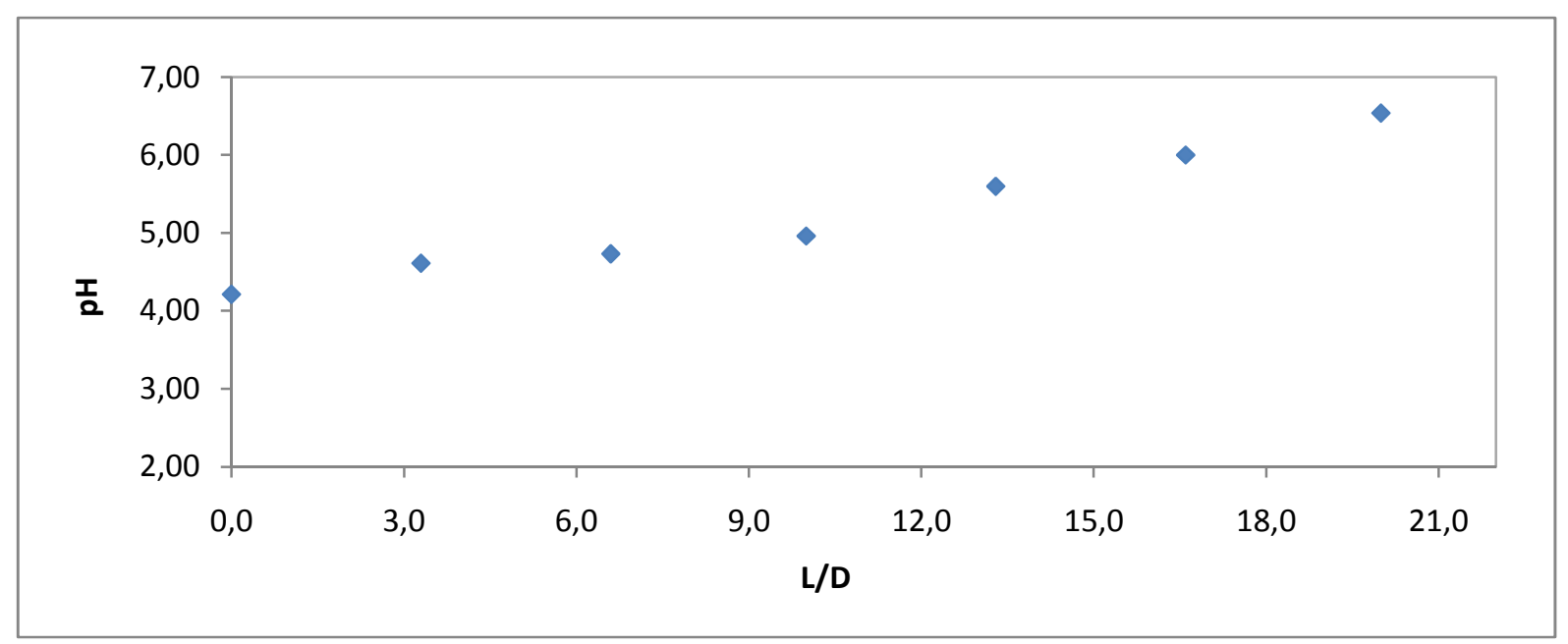

Figura 5.35. Variação do pH ao longo do reator R3 na fase II.

O consumo da DQO e do sulfato também ocorreram de maneira contínua ao longo do leito até a saída do reator (Figura 5.36). A relação $\mathrm{DQO} / \mathrm{SO}_{4}{ }^{2-}$ de 1,0 manteve-se nos dois primeiros pontos de amostragem, sendo que no $3^{\circ}, 4^{\circ}, 6^{\circ}$ e $7^{\circ}$ ponto, esta ficou um pouco mais elevada. Apenas no $4^{\circ}$ ponto de amostragem, essa relação foi 1,0. A geração de sulfeto nessa fase ocorreu de maneira proporcional a remoção de sulfato, aumentando continuamente ao longo do reator. 


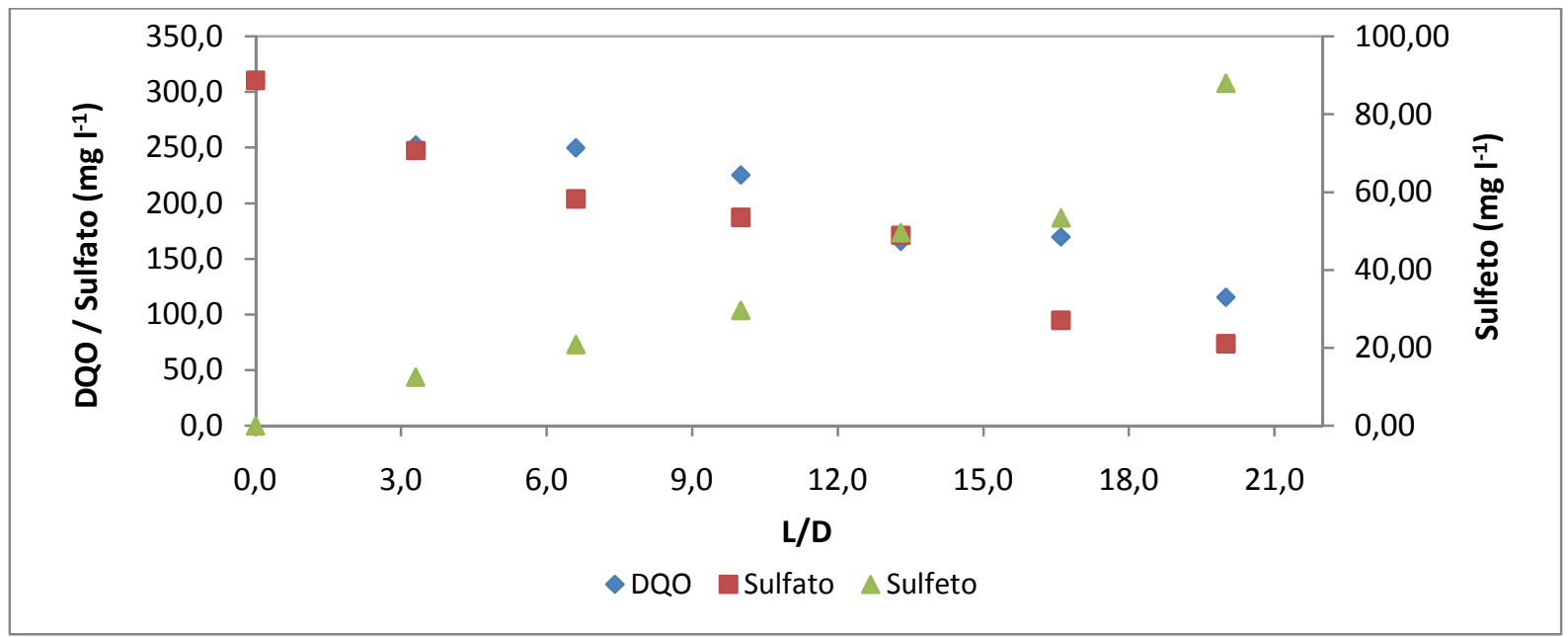

Figura 5.36. Variação nas concentrações de DQO, sulfato e sulfeto ao longo do reator R3 na fase II.

O consumo de etanol ocorreu de maneira semelhante a fase I, sendo mais intensamente utilizado entre o afluente e L/D de 3,3 e decrescendo até o fim do reator como apresentado na Figura 5.37. A geração de ácido acético também foi expressiva entre os pontos esses mesmos pontos, porém notou-se aumento até L/D de 6,6. Nesse perfil, a concentração final de acetato ficou próxima a $40 \mathrm{mg} \mathrm{l}^{-1}$, entretanto, na média, durante a fase II, observou-se concentrações de acetato inferiores a $10 \mathrm{mg} \mathrm{l}^{-1}$.

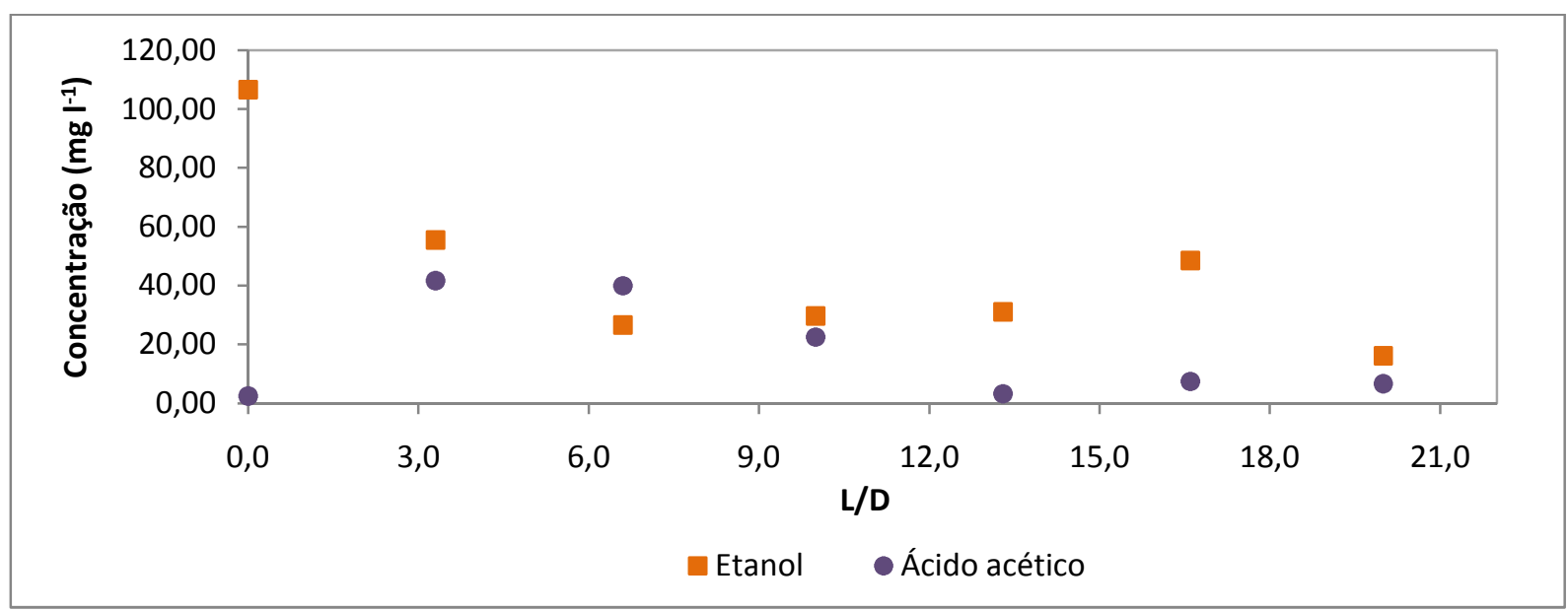

Figura 5.37. Variação das concentrações de etanol e ácido acético ao longo do reator R3 na fase II. 
5.3.7 Avaliação da diversidade microbiana dos reatores RAHLF por técnicas biologia molecular

Ao término da operação dos reatores RAHLF, foram realizadas análises de biologia molecular para estudo da diversidade microbiana dos reatores. Os ensaios de biologia molecular utilizaram primers específicos para o Dominio Bactéria e para o Dominio Archaea.

Para os reatores R1 e R2 foram obtidos cerca de 50 clones para cada Domínio, enquanto para o reator R3 foram cerca de 100 clones apenas para o Domínio Bactéria, visto que as reações de polimerase em cadeia (PCR) com primers de Archaea para esse reator não apresentaram resultado positivo.

\subsubsection{Diversidade para o Domínio Archaea}

Os clones do reator R1 para o Dominio Archaea foram agrupados em 19 unidades taxonômicas operacionais (UTOs), as quais foram classificadas de acordo com a classe pertencente. A Figura 5.38 apresenta a distribuição percentual dos clones do reator R1 nessas classes.

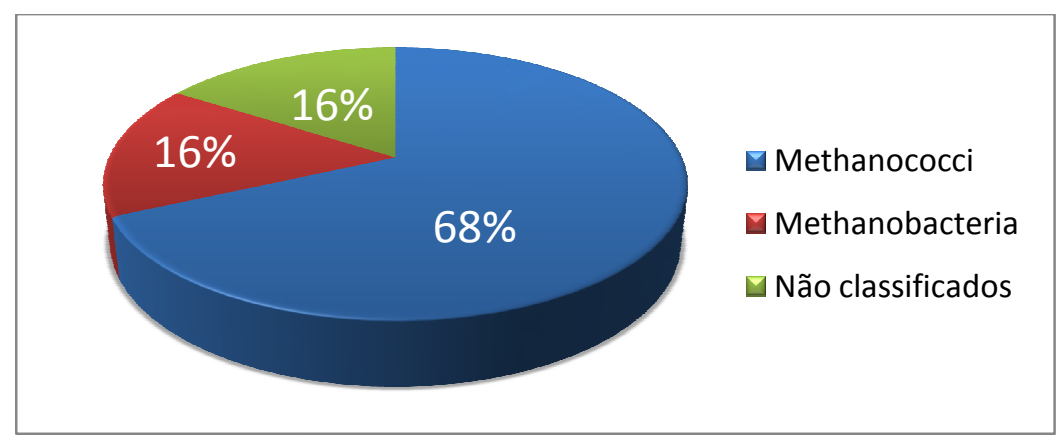

Figura 5.38. Distribuição dos clones do reator R1 para o Dominio Archaea. 
Nota-se predomínio da classe Methanococci entre as UTOs desse reator, com $68 \%$ dos clones pertencentes a essa classe, enquanto que para a classe Methanobacteria, apenas 16\% dos clones foram classificados. Os $16 \%$ restantes foram clones não classificados em nenhum filo.

Dentro da classe Methanococci, 40\% dos clones eram da ordem Methanosarcinales e $60 \%$ dos clones da ordem Methanomicrobiales. Na classe Methanobacteria, todos os clones eram pertencentes a ordem Methanobacteriaceae.

Os clones do reator R2 também foram agrupados em UTOs e separados de acordo com a classe correspondente (Figura 5.39).

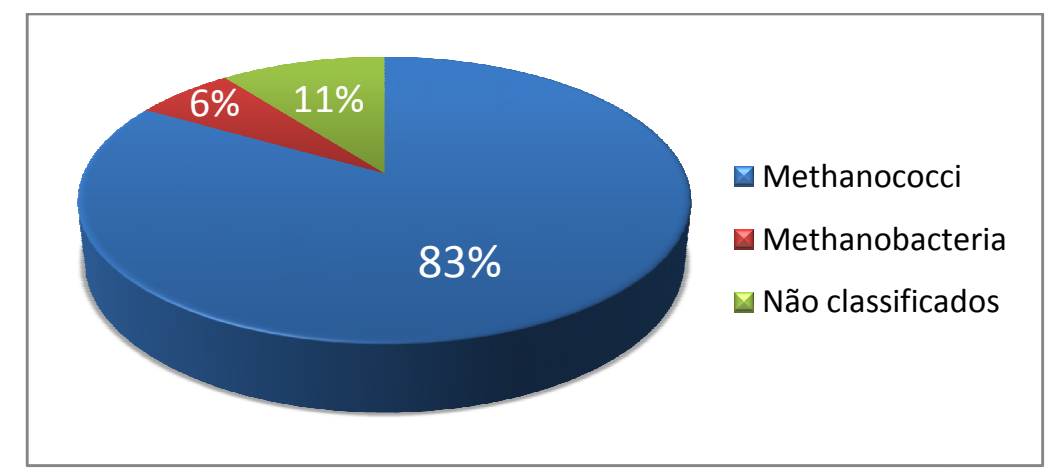

Figura 5.39. Distribuição dos clones do reator R2 para o Dominio Archaea.

A classe Methanocoocci também foi o predominante para as amostras de Archaea desse reator, com 83\% dos clones. Em menor incidência, esteve a classe Methanobacteria, com $6 \%$ dos clones e $11 \%$ deles foram não classificados. As condições de $\mathrm{pH}$ mais elevado deste reator parecem ter selecionado ainda mais os representantes da classe Methanococci.

Na classe Methanococci, 42,5\% dos clones pertenciam a ordem Methanosarcinales e $57,5 \%$ a ordem Methanomicrobiales. Para a classe Methanobacteria, todos os clones pertenciam a ordem Methanobacteriales. 
Os representantes da ordem Methanosarcinales podem catalisar a oxidação final da matéria orgânica em ambientes anóxicos quando luz e receptores de elétrons diferentes do $\mathrm{CO}_{2}$ forem limitantes. Possuem uma grande variedade de substratos e podem crescer reduzindo o $\mathrm{CO}_{2}$ na presença de $\mathrm{H}_{2}$, pela dimetilação de compostos com grupo metil ou utilizando o acetato. Todos os membros do gênero Methanosaeta podem crescer em acetato e são encontrados normalmente em digestores anaeróbios e sedimentos (Kendall e Boone, 2006).

As espécies da ordem Methanomicrobiales possuem como substrato preferencial o $\mathrm{H}_{2}$ e o $\mathrm{CO}_{2}$ para a metanogênese, porém a maioria das espécies também pode utilizar o formato e alguns álcoois. Não utilizam acetato e compostos metilados como o metanol, metilaminas e metilsulfetos e esta propriedade as distingue da ordem Methanosarcinales. Porém, o acetato pode ser requerido como fonte de carbono (Garcia et al., 2006).

A ordem Methanobacteriales se diferencia das outras arqueias metanogênicas pela sua limitada variedade de substratos, sua morfologia, composição dos lipídeos e sequencia de DNA. São geralmente hidrogenotróficas e usam o $\mathrm{H}_{2}$ para reduzir o $\mathrm{CO}_{2}$ a $\mathrm{CH}_{4}$. Alguns membros podem utilizar o formato, $\mathrm{CO}$ ou álcoois secundários como doadores de elétrons. (Bonin e Boone, 2006)

De acordo com a literatura (Wolfe, 2006; Muyzer e Stams, 2008), dentro do domínio Archaea, a redução de sulfato é realizada apenas arqueias hipertermofilicas, com temperatura ótima de crescimento acima de $80^{\circ}$ C. É muito improvável que nesses reatores, elas estivessem presentes. Acredita-se, portanto, que a redução de sulfato observada nos reatores R1 e R2 foi resultado apenas da atividade de bactérias redutoras de sulfato.

A Figura 5.40 apresenta uma fotografia do gel de PCR do reator R3 utilizando o primer de Archaea. É possível notar que para a amostra desse reator não foi obtida banda na 
corrida do gel, o que indica que a PCR não se realizou. Foram testadas três reações de PCR e todas apresentaram resultados negativos. Considerando que o reator R3 foi o que apresentou as melhores eficiências para a redução de sulfato durante longo período de operação (365 dias), acredita-se que a sulfetogênese tenha se sobreposto sobre quaisquer outros processos de utilização da matéria orgânica e com isso, a comunidade de arqueias tenha sido eliminada da biomassa do reator.

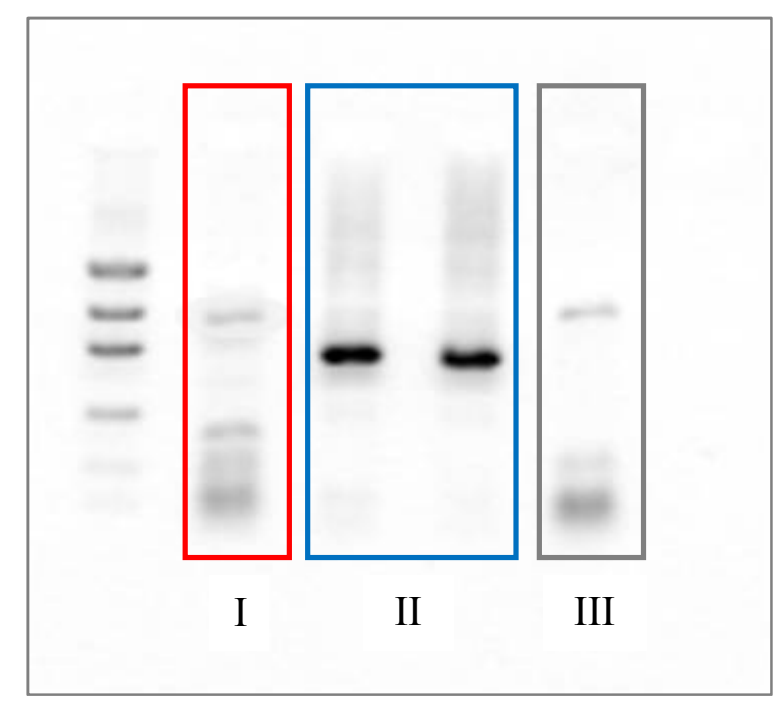

Figura 5.40. PCR de Archaea para o reator R3 (I: amostra, II: controles positivos, III: branco).

\subsubsection{Diversidade para o Domínio Bacteria}

A diversidade para o Dominio Bacteria também foi estudada para o 3 reatores RAHLF. A Figura 5.41 apresenta os resultados obtidos para o reator R1. 


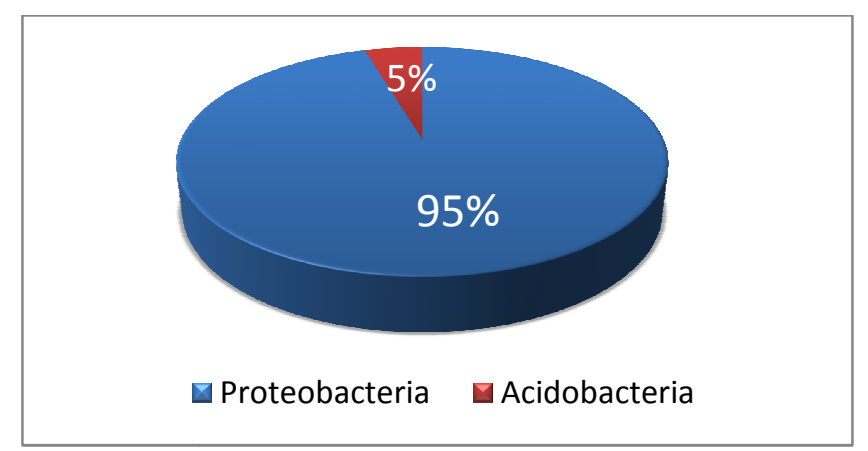

Figura 5.41. Distribuição dos clones do reator R1 para o Dominio Bacteria.

A grande maioria dos clones (95\%) foi agrupada no filo Proteobacteria, classe Gamaproteobacteria, sendo que dentro deste filo $28 \%$ dos clones foram classificados apenas como Gamaproteobacteria, 17\% dos clones pertenciam a ordem Burkholderiales e 55\% deles à ordem Acidithiobacillales. Dos clones pertencentes ao filo Acidobacteria, todos eram da ordem Acidobacteriales.

Segundo Garrity et al. (2001), o filo Proteobacteria está dividido em cinco classes e 12 grupos fenotípicos com características bastante heterogêneas. Entre aqueles relacionados ao ciclo do enxofre, estão as bactérias anoxigênicas fototróficas, que podem utilizar o sulfeto e o enxofre elementar como doadores de elétrons na assimilação do $\mathrm{CO}_{2}$ e apresentar vacúolos com acúmulo de enxofre elementar na parede celular. As bactérias aeróbicas quimiolitotróficas são outro grupo fenotípico dentro desse filo e caracterizam-se por serem oxidadoras de enxofre elementar ou compostos reduzidos de enxofre e podem, ainda, utilizar o $\mathrm{H}_{2}$ como doador de elétrons.

O filo Acidobacteria está caracterizado por dois grupos fenotípicos, sendo um Gramnegativo, aeróbio, quimiorganotrófico e mesofílico, mas com tolerância a pH ácido. O segundo grupo consiste de representantes Gram-negativos, quimiorganotróficos, anaeróbios e obtém energia através da fermentação ou respiração anaeróbia. 
A prevalência de clones na ordem Acidithiobacillales demonstrou que, nesse reator, a flora bacteriana mantinha a diversidade que se esperaria encontrar em ambientes de mineração, com a presença de bactérias oxidadoras de sulfetos metálicos e com pH ácido como o mais favorável ao seu desenvolvimento. Lembrando que este reator era alimentado com drenagem bruta e um $\mathrm{pH}$ próximo a 3,0, era de se esperar que as bactérias oriundas da própria drenagem fossem capazes de se manter nesse ambiente, mesmo em condições com concentrações muito baixas de oxigênio.

A análise da diversidade bacteriana do reator $\mathrm{R} 2$ mostrou resultados muito distintos dos obtidos no reator R1, como mostrado na Figura 5.42.

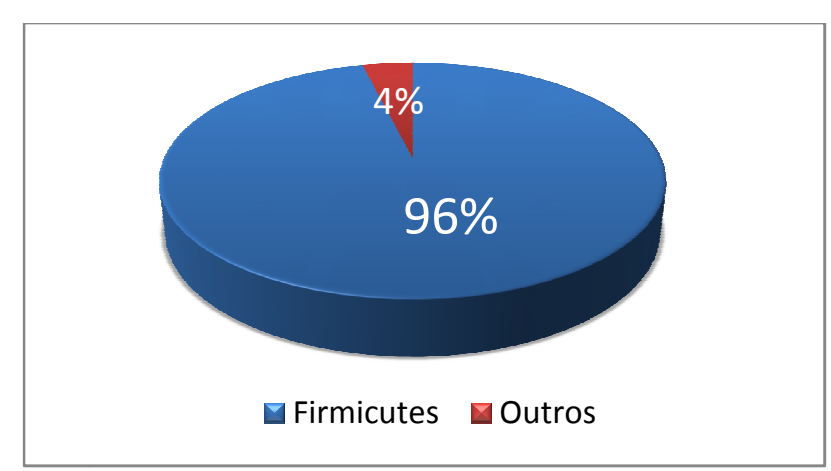

Figura 5.42. Distribuição dos clones do reator R2 para o Dominio Bacteria.

O reator R2 apresentou uma prevalência de clones do filo Firmicutes, sendo todos da classe Clostridia e ordem Clostridilaes. Apenas dois clones não foram classificados neste filo, sendo um classificado como Chlorobi e o outro como Cyanobacteria.

Esse resultado foi um indicativo de que o controle de $\mathrm{pH}$ afluente realizado na fase I deste reator e a redução da carga de sulfato na fase II selecionaram uma microflora muito distintas neste reator. Provavelmente, a existência de uma biomassa mais adaptada à essas 
condições foi a responsável pela melhora na eficiência desse reator quando comparado ao reator R1.

O mesmo foi observado no estudo da diversidade do reator R3 (Figura 5.43).

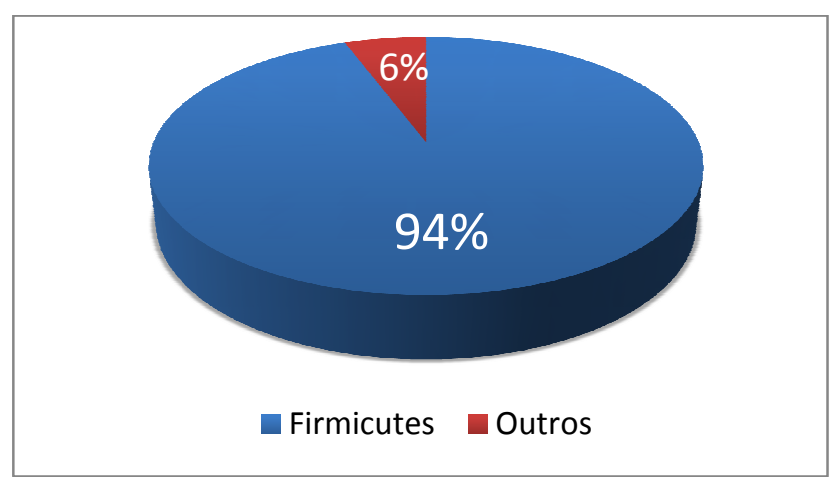

Figura 5.43. Distribuição dos clones do reator R3 para o Dominio Bacteria.

Da mesma forma que no reator R2, no reator R3 verificou-se prevalência de clones no filo Firmicutes, sendo que apenas um clone era pertencente ao filo Actinobacteria, um clone no filo Cyanobacteria e um clone no filo Proteobacteria. Três clones ficaram sem classificação em filos específicos.

Ainda de acordo com Garrity et al. (2001) o filo Firmicutes está subdividido em três classes: Clostridia, Mollicutes e Bacilli e são bactérias Gram-positivas com baixo conteúdo G+C. O filo se divide em 13 grupos fenotíicos e apresenta dois deles relacionados ao ciclo do enxofre. No primeiro estão presentes as bactérias aeróbias, oxidadoras de compostos reduzidos de enxofre, tendo o gênero Sulfobacillus, classe Bacilli, como representante desse grupo. No segundo grupo encontram-se as bactérias redutoras de sulfato ou sulfito, que são quimiorganotróficas e respiram anaerobicamente utilizando sulfato, sulfito ou enxofre elementar como receptores finais de elétrons, sendo representadas pelo gênero Desulfotomaculum, classe Clostridia. 
O filo Chlorobi contém uma única classe, ordem e família. São bactérias Gramnegatovas, anaeróbias e obrigatoriamente fototróficas. As células crescem preferencialmente por fotoassimilação de moléculas orgânicas simples. Algumas espécies podem utilizar o sulfeto e o tiossulfato como doadores de elétrons. Acúmulo de enxofre elementar pode ocorrer na parede externa da célula, quando o crescimento ocorrer na presença de sulfeto e luz, e o enxofre é raramente oxidado a sulfato. A maioria dos gêneros é capaz de crescer em condições de micro-aerofilia. Vale ressaltar que ao longo do leito do reator era possível visualizar o acúmulo de uma substância amarelada parecida com enxofre elementar.

As características do filo Cyanobacteria são muito peculiares e mesmo sendo um constituinte do domínio Bacteria, sua nomenclatura e taxonomia estão sob a responsabilidade do Código Botânico de Nomenclaturas. São bactérias Gram-negativas, fotossintéticas e que exibem uma morfologia complexa. São em sua maioria fotoheterotróficas, porém podem ser quimioheterotróficas em algumas linhagens. Hodges (1992) relata que poderia existir uma interação em comunidades microbianas complexas entre cianobactérias e bactérias redutoras de sulfato.

O filo Actinobacteria apresenta características fenotípicas muito heterogêneas entre seus representantes, mas contém um gênero, Acidimicrobium, que possui a capacidade de oxidar compostos reduzidos de enxofre como única fonte de elétrons na presença de $\mathrm{O}_{2}$.

\subsubsection{3 Árvore Filogenética}

Os clones dos reatores RAHLF após serem agrupados em UTOs foram alinhados e utilizados nos programa ARB para a construção da árvore filogenética para os domínios Archaea e Bacteria (Figura 5.44). A árvore filogenética obtida para os clones dos reatores 
estudados resultou em uma distribuição de filos e classes de acordo com os gráficos de diversidade já apresentados, porém poucas UTOs foram alinhadas próximas a microrganismos classificados, principalmente para o domínio Archaea.

Com relação ao domínio Archaea, a maioria das UTOs classificadas na ordem Methanomicrobiales alinharam-se com clones não cultivados de Archaea descritos no GenBank. Apenas a espécie Methanoregula boonei apareceu entre os clones dessa família. Na ordem Methanosarcinales, as UTOs também alinharam-se com clones descritos no GenBank e apenas a espécie Methanosaeta concilii apareceu dentro desta família mais próxima aos clones dos reatores RAHLF 2. Dentro dessa ordem, apenas uma UTO do reator R2 foi classificada e alinhou-se com a espécie Methanomethylovorans hollandica. A espécie Methanosarcina barkeri foi adicionada como uma representante dessa família.

Dentro da ordem Methanobacteriales, foram classificadas UTOs dos reatores R1 e R2 e o alinhamento com Metanobacterium sp. foi proposto. Um clone de digestor anaeróbio descrito no GenBank também foi adicionado ao alinhamento.

Muitas UTOs foram consideradas como não classificadas tanto para o reator R1 quanto para o R2 e foram alinhadas com clones descritos no GenBank.

Para uma análise mais detalhada dessa proximidade das UTOs pertencentes ao domínio Archaea, optou-se por construir a Tabela 5.8 que relaciona as UTOs dos reatores R1 e R2 aos microrganismos ou aos clones sugeridos como próximos na árvore construída no software ARB. 


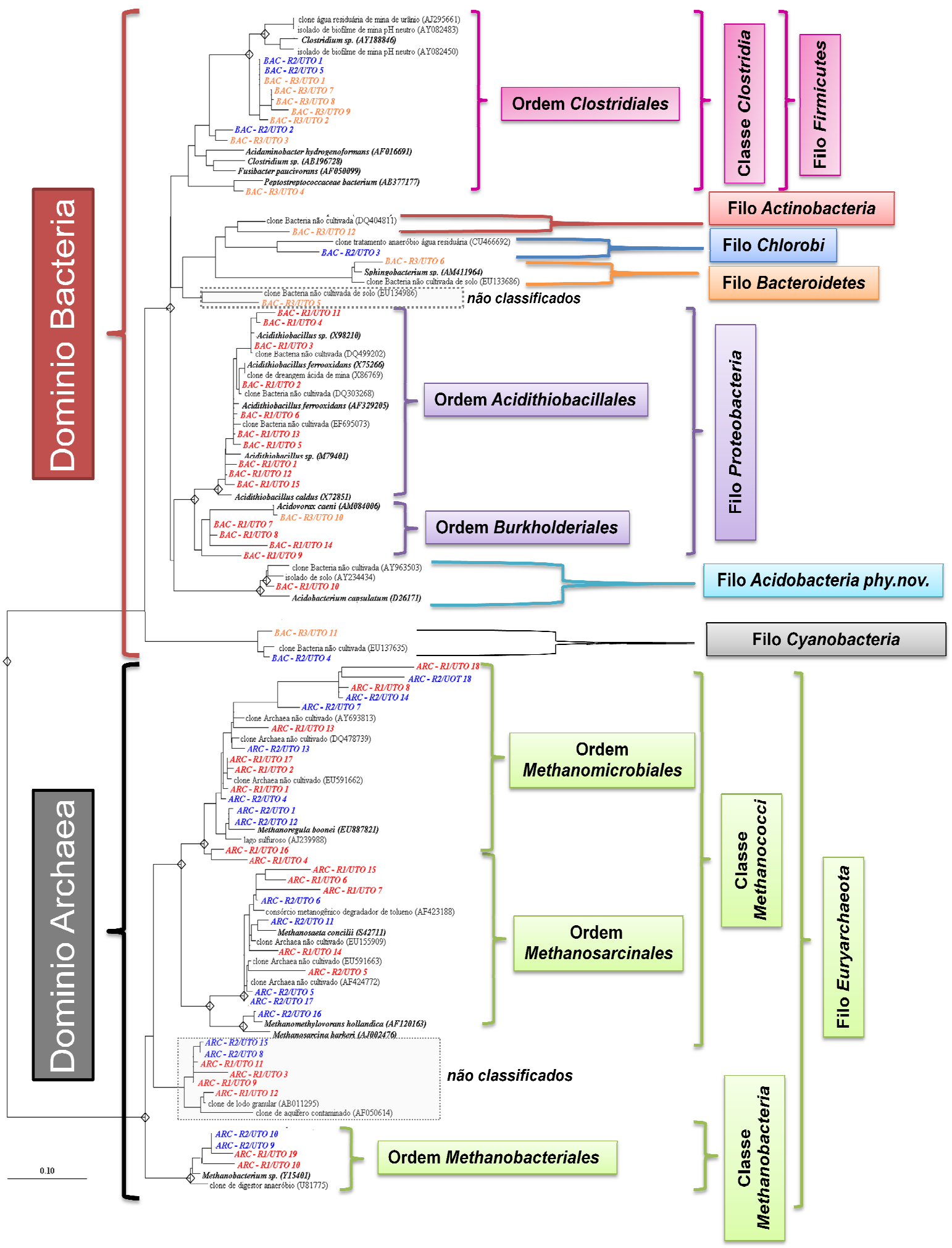

Figura 5.44. Arvore filogenética dos reatores R1, R2 e R3 (não classificados: clones não classificados em nenhum filo do domínio correspondente). 
Tabela 5.7. Comparação de identidade para as UTOs de Archaea dos reatores R1 e R2 (Pb: pares de bases).

\begin{tabular}{|c|c|c|c|c|c|c|c|c|}
\hline Reator & UTO & $N^{o}$ clones & $P b$ & Identidade & $\begin{array}{c}\text { Organismo } \\
\text { (como descrito no GenBank) }\end{array}$ & $\begin{array}{c}\text { Acesso } \\
\text { GenBank }\end{array}$ & Abundância & Referência \\
\hline R1 & 1 & 5 & 612 & $93 \%$ & \multirow{3}{*}{ uncultured archaeon } & \multirow{3}{*}{ EU591662 } & $11 \%$ & \multirow{3}{*}{ NP } \\
\hline R1 & 2 & 2 & 590 & $97 \%$ & & & $4,5 \%$ & \\
\hline $\mathrm{R} 1$ & 17 & 3 & 592 & $97 \%$ & & & $7 \%$ & \\
\hline $\mathrm{R} 1$ & 5 & 3 & 641 & $88 \%$ & uncultured archaeon & EU591663 & $7 \%$ & NP \\
\hline $\mathrm{R} 1$ & 6 & 4 & 633 & $90 \%$ & \multirow{3}{*}{$\begin{array}{l}\text { toluene-degrading methanogenic } \\
\text { consortium archaeon }\end{array}$} & \multirow{3}{*}{ AF423188 } & $9 \%$ & \multirow{3}{*}{ Ficker et al., 1999} \\
\hline $\mathrm{R} 1$ & 7 & 1 & 600 & $88 \%$ & & & $2 \%$ & \\
\hline $\mathrm{R} 1$ & 15 & 1 & 600 & $100 \%$ & & & $2 \%$ & \\
\hline \multirow{2}{*}{ R1 } & \multirow{2}{*}{10} & \multirow{2}{*}{2} & \multirow{2}{*}{591} & $100 \%$ & unidentified archaeon & U81775 & \multirow{2}{*}{$4,5 \%$} & \multirow{2}{*}{$\begin{array}{c}\text { Godon et al., } 1997 \\
\text { Grosskopf et al., } 1998\end{array}$} \\
\hline & & & & $87 \%$ & Methanobacterium sp. & Y15401 & & \\
\hline \multirow{2}{*}{ R1 } & \multirow{2}{*}{19} & \multirow{2}{*}{5} & \multirow{2}{*}{622} & $87 \%$ & unidentified archaeon & U81775 & \multirow{2}{*}{$11 \%$} & \multirow{2}{*}{$\begin{array}{l}\text { Godon et al., } 1997 \\
\text { Grosskopf et al., } 1998\end{array}$} \\
\hline & & & & $90 \%$ & Methanobacterium sp. & Y15401 & & \\
\hline \multirow{2}{*}{$\mathrm{R} 1$} & \multirow{2}{*}{12} & \multirow{2}{*}{1} & \multirow{2}{*}{600} & $98 \%$ & unidentified euryarchaeote & AB011295 & \multirow[b]{2}{*}{$2 \%$} & \multirow{2}{*}{$\begin{array}{l}\text { Sekiguchi et al., } 1998 \\
\text { Dojka et al., } 1998\end{array}$} \\
\hline & & & & $100 \%$ & uncultured archaeon WCHA1-57 & AF050614 & & \\
\hline R1 & 13 & 1 & 600 & $98 \%$ & uncultured euryarchaeote & AY693813 & $2 \%$ & $\mathrm{NP}$ \\
\hline $\mathrm{R} 1$ & 14 & 3 & 617 & $90 \%$ & uncultured archaeon & EU155909 & $7 \%$ & Cadillo-Quiroz et al. 2008 \\
\hline R2 & 1 & 11 & 635 & $96 \%$ & \multirow{2}{*}{ Candidatus Methanoregula boonei } & \multirow{2}{*}{ EU887821 } & $25 \%$ & \multirow{2}{*}{ NP } \\
\hline $\mathrm{R} 2$ & 12 & 4 & 648 & $96 \%$ & & & $9 \%$ & \\
\hline $\mathrm{R} 2$ & 2 & 7 & 654 & $98 \%$ & \multirow{2}{*}{ uncultured archaeon } & \multirow{2}{*}{ AF424772 } & $15 \%$ & \multirow{2}{*}{ NP } \\
\hline $\mathrm{R} 2$ & 5 & 2 & 647 & $97 \%$ & & & $4 \%$ & \\
\hline $\mathrm{R} 2$ & 4 & 2 & 603 & $94 \%$ & uncultured archaeon & EU591662 & $4 \%$ & $\mathrm{NP}$ \\
\hline $\mathrm{R} 2$ & 6 & 4 & 638 & $95 \%$ & $\begin{array}{l}\text { toluene-degrading methanogenic } \\
\text { consortium archaeon }\end{array}$ & AF423188 & $9 \%$ & Ficker et al., 1999 \\
\hline $\mathrm{R} 2$ & 9 & 1 & 620 & $93 \%$ & Methanobacterium $s p$. & Y15401 & $2 \%$ & Grosskopf et al., 1998 \\
\hline K2 & 9 & 1 & $0 \angle 0$ & $96 \%$ & unidentified archaeon & U81775 & $2 \%$ & Godon et al., 1997 \\
\hline R2 & 10 & 2 & 634 & $95 \%$ & Methanobacterium sp. & Y15401 & & Grosskopf et al., 1998 \\
\hline K2 & 10 & 2 & 034 & $96 \%$ & unidentified archaeon & U81775 & $4 \%$ & Godon et al., 1997 \\
\hline $\mathrm{R} 2$ & 11 & 1 & 609 & $98 \%$ & Methanosaeta concilii & S42711 & $2 \%$ & Kamagata et al., 1992 \\
\hline $\mathrm{R} 2$ & 13 & 1 & 625 & $98 \%$ & uncultured archaeon & DQ478739 & $2 \%$ & Diaz et al., 2006 \\
\hline $\mathrm{R} 2$ & 16 & 3 & 657 & $98 \%$ & Methanomethylovorans hollandica & AF120163 & $6 \%$ & Lomans et al., 1999 \\
\hline
\end{tabular}


Apenas os reatores R1 e R2 apresentaram sequências pertencentes ao domínio Archaea. Entretanto, o alinhamento dos clones desses reatores ocorreu em sua maioria com arqueias não cultivadas.

As UTOs 1,2, 5 e 17 do reator R1 e a UTO 4 do reator R2 alinharam-se com clone de arqueia não cultivada descrita no GenBank como um isolado de reator metanogênico.

As UTOs 6, 7 e 15 do reator R1 e a UTO 6 do reator R2 alinharam-se com um clone descrito por Ficker et al. (1999) como um isolado de um consórcio microbiano degradador de tolueno. Nesse trabalho, os autores encontraram, além dos clones de arqueias, clones do gênero Desulfotomaculum, proposto como o responsável pelo ataque inicial ao tolueno.

Godon et al. (1997) estudaram a comunidade microbiana de digestores anaeróbios e descrever um clone de arqueia não cultivado que alinhou-se com as UTOs 10 e 19 do reator R1 e com as UTOs 9 e 10 do reator R2. Essas quatro UTOs também apresentaram certa identidade com Methanobacterium sp., referenciada no trabalho de Grosskopf et al. (1998) sobre a diversidade microbiana em campos de arroz.

A UTO 12 do reator R1 alinhou-se com clones de arqueias não cultivadas descritos por Sekiguchi et al. (1998) e por Dojka et al. (1998). Os primeiros autores estudaram a diversidade de lodo granular para o domínio Archaea e os segundos analisaram a diversidade de aquíferos contaminados por solventes orgânicos que estavam em processo de bioremediação.

As UTOs 13 e 14 do reator R1 também alinharam-se com clones de arqueias não cultivadas, sendo que a UTO 13 apresentou identidade de $98 \%$ com um clone descrito no GenBank como originário de lodo granular, enquanto a UTO 14 apresentou $90 \%$ de identidade com um clone descrito por Cadillo-Quiroz (2008) originário de pântano. 
No reator R2, as UTOs 1 e 12 alinharam-se com 96\% de identidade com um organismo candidato a Metanoregula boonei, presentes em digestores anaeróbios como descrito no GenBank.

As UTOs 2 e 5 do RALHF 2 alinharam-se com clones não cultivados, mas descritos no GenBank, e que foram encontrados em reatores de tratamento de esgoto municipal. Da mesma foram, a UTO 13 também alinhou-se com um clone de arqueia não cultivada, encontrada em reator UASB tratando resíduo de cervejaria, como descrito no GenBank.

E a UTO 16 do reator R2 apresentou 98\% de identidade com a espécie Methanomethylovorans hollandica, isolada de sedimento de lago e descrita como uma nova espécie no trabalho de Lomans et al. (1999). Os autores caracterizam essa espécie como a única arqueia capaz de utilizar dimetilsulfeto como única fonte de energia e carbono.

Os resultados para o domínio Archaea mostraram que os clones dos reatores R1 e R2 apresentaram diferenças entre si, porém muitos apresentaram identidade superior a $90 \%$ com clones de arqueias não cultivadas e a maioria delas, encontradas em lodo granular ou reatores anaeróbios. Como o inóculo dos reatores em estudo foi lodo granular de reator UASB, é coerente que esses microrganismos estivessem presentes no inóculo e mesmo com as condições mais restritas desses reatores, conseguiram permanecer na biomassa dos reatores R1 e R2.

Com relação ao domínio Bacteria, a maioria das UTOs do reator R1 foi classificada dentro do filo Proteobacteria e alinhou-se a alguns representantes da ordem Acidithiobacillales, como Acidithiobacillus sp., At.ferrooxidans, At. thiooxidans e At. caldus. Três UTOs não se alinharam com nenhum gênero conhecido e uma UTO alinhou-se com Acidobacterium capsulatum. Clones descritos no GenBank também foram incluídos na árvore para comparação. 
As UTOs dos reatores R2 e R3 foram, em sua maioria, classificadas no filo Firmicutes, na classe Clostridia. Muitas apresentaram proximidade com Clostridium sp., Acidaminobacter hydrogenomorfans, Fusibacter paucivorans, Peptostreptococcaceae bacterium e clones isolados de minas de urânio. Uma UTO do reator R3 alinhou-se próxima a Sphingobacterium sp., pertencente ao filo Bacteroidetes e outra UTO alinhou-se próxima a Acidovorax caeni, pertencente ao filo Proteobacteria.

A análise de proximidade das UTOs para o domínio Bacteria também foi realizada para os reatores R1, R2 e R3 e estão mostradas na Tabela 5.9.

As UTOs 1, 2, 5, 6, 12, 13 e 15 do reator R1 alinharam-se com representantes do gênero Acidithiobacillus com mais de $90 \%$ de identidade. Esse gênero como citado anteriormente está caracterizado por bactérias aeróbias, quimiolitotróficas, capazes de utilizar compostos reduzidos de enxofre como doador de elétrons. São comumente encontrados em ambientes de mineração, quando há presença extensiva de sulfetos metálicos.

Em seu trabalho sobre a relação evolucionária entre as bactérias oxidadoras de ferro e de enxofre, Lane et al. (1992) utilizaram várias espécies do gênero Acidithiobacillus (anteriormente classificadas como Thiobacillus) isoladas basicamente de ambientes onde ocorriam processos de biolixiviação, como minas de carvão, de cobre e de urânio.

Goebel e Stackebrandt (1994) analisaram a filogenia de populações microbianas encontradas em ambientes de biolixiviação cujo pH estava entre 2,5 e 3,5 e encontraram em sua maioria representantes das espécies Acidithiobacillus ferrooxidans e Acidithiobacillus thiooxidans 
Tabela 5.8 (continua). Comparação de identidade para as UTOs de Bacteria dos reatores R1, R2 e R3 (Pb: pares de bases).

\begin{tabular}{|c|c|c|c|c|c|c|c|c|}
\hline Reator & UTO & $N^{o}$ clones & $P b$ & Identidade & $\begin{array}{c}\text { Organismo } \\
\text { (como descrito no GenBank) }\end{array}$ & $\begin{array}{c}\text { Acesso } \\
\text { GenBank }\end{array}$ & $\begin{array}{c}\text { Abundância } \\
\text { (\%) }\end{array}$ & Referência \\
\hline $\mathrm{R} 1$ & 1 & 2 & 617 & $\begin{array}{l}88 \% \\
92 \%\end{array}$ & $\begin{array}{l}\text { Acidithiobacillus thiooxidans } \\
\text { Acidithiobacillus caldus }\end{array}$ & $\begin{array}{l}\text { M79401 } \\
\text { X72851 }\end{array}$ & $4,5 \%$ & $\begin{array}{c}\text { Lane } \text { et al., } 1992 \\
\text { Goebel e Stackebrandt, } 1994\end{array}$ \\
\hline $\mathrm{R} 1$ & 12 & 6 & 622 & $\begin{array}{l}90 \% \\
91 \% \\
\end{array}$ & $\begin{array}{c}\text { Acidithiobacillus thiooxidans } \\
\text { Acidithiobacillus caldus }\end{array}$ & $\begin{array}{l}\text { M79401 } \\
\text { X72851 } \\
\end{array}$ & $14 \%$ & $\begin{array}{c}\text { Lane } \text { et al., } 1992 \\
\text { Goebel e Stackebrandt, } 1994 \\
\end{array}$ \\
\hline R1 & 15 & 1 & 579 & $\begin{array}{l}90 \% \\
93 \% \\
\end{array}$ & $\begin{array}{c}\text { Acidithiobacillus thiooxidans } \\
\text { Acidithiobacillus caldus }\end{array}$ & $\begin{array}{l}\text { M79401 } \\
\text { X72851 } \\
\end{array}$ & $2 \%$ & $\begin{array}{c}\text { Lane } \text { et al., } 1992 \\
\text { Goebel e Stackebrandt, } 1994 \\
\end{array}$ \\
\hline R1 & 2 & 2 & 622 & $\begin{array}{l}97 \% \\
97 \% \\
98 \% \\
\end{array}$ & $\begin{array}{c}\text { Acidithiobacillus ferrooxidans } \\
\text { unidentified bacterium } \\
\text { uncultured bacterium }\end{array}$ & $\begin{array}{c}\mathrm{X} 75266 \\
\mathrm{X} 86769 \\
\mathrm{DQ} 303268\end{array}$ & $4,5 \%$ & $\begin{array}{c}\text { Goebel e Stackebrandt, } 1994 \\
\text { NP } \\
\text { Garcia-Moyano et al., } 2007\end{array}$ \\
\hline R1 & 3 & 2 & 600 & $\begin{array}{l}95 \% \\
96 \%\end{array}$ & $\begin{array}{l}\text { Acidithiobacillus sp. } \\
\text { uncultured bacterium }\end{array}$ & $\begin{array}{c}\text { X98210 } \\
\text { DQ499202 }\end{array}$ & $4,5 \%$ & $\begin{array}{l}\text { Vasquez e Espejo, } 1997 \\
\text { Macalady et al., } 2007\end{array}$ \\
\hline R1 & 4 & 1 & 600 & $\begin{array}{l}98 \% \\
99 \% \\
\end{array}$ & $\begin{array}{l}\text { Acidithiobacillus } s p \text {. } \\
\text { uncultured bacterium }\end{array}$ & $\begin{array}{c}\text { X98210 } \\
\text { DQ499202 }\end{array}$ & $2 \%$ & $\begin{array}{l}\text { Vasquez e Espejo, } 1997 \\
\text { Macalady et al., } 2007\end{array}$ \\
\hline R1 & 11 & 1 & 608 & $\begin{array}{l}97 \% \\
97 \%\end{array}$ & $\begin{array}{l}\text { Acidithiobacillus sp. } \\
\text { uncultured bacterium }\end{array}$ & $\begin{array}{c}\text { X98210 } \\
\text { DQ499202 }\end{array}$ & $2 \%$ & $\begin{array}{l}\text { Vasquez e Espejo, } 1997 \\
\text { Macalady et al., } 2007\end{array}$ \\
\hline R1 & 5 & 4 & 624 & $\begin{array}{l}94 \% \\
96 \% \\
\end{array}$ & $\begin{array}{c}\text { Acidithiobacillus ferrooxidans } \\
\text { uncultured bacterium }\end{array}$ & $\begin{array}{l}\text { AF329205 } \\
\text { EF695073 }\end{array}$ & $9 \%$ & $\begin{array}{l}\mathrm{NP} \\
\mathrm{NP}\end{array}$ \\
\hline R1 & 6 & 2 & 614 & $\begin{array}{l}96 \% \\
94 \% \\
\end{array}$ & $\begin{array}{c}\text { Acidithiobacillus ferrooxidans } \\
\text { uncultured bacterium }\end{array}$ & $\begin{array}{l}\text { AF329205 } \\
\text { EF695073 }\end{array}$ & $4,5 \%$ & $\begin{array}{l}\mathrm{NP} \\
\mathrm{NP}\end{array}$ \\
\hline R1 & 13 & 2 & 611 & $\begin{array}{l}95 \% \\
95 \%\end{array}$ & $\begin{array}{c}\text { Acidithiobacillus ferrooxidans } \\
\text { uncultured bacterium }\end{array}$ & $\begin{array}{l}\text { AF329205 } \\
\text { EF695073 }\end{array}$ & $4,5 \%$ & $\begin{array}{l}\mathrm{NP} \\
\mathrm{NP}\end{array}$ \\
\hline R1 & 10 & 2 & 611 & $\begin{array}{l}93 \% \\
97 \% \\
98 \% \\
\end{array}$ & $\begin{array}{c}\text { Acidobacterium capsulatum } \\
\text { bacterium Ellin5017 } \\
\text { uncultured bacterium }\end{array}$ & $\begin{array}{c}\text { D26171 } \\
\text { AY234434 } \\
\text { AY963503 } \\
\end{array}$ & $4,5 \%$ & $\begin{array}{l}\text { Hiraishi et al., } 1995 \\
\text { Joseph et al., } 2003 \\
\text { Chan } \text { et al., } 2006 \\
\end{array}$ \\
\hline $\mathrm{R} 2$ & 1 & 31 & 643 & $\begin{array}{c}100 \% \\
100 \% \\
100 \% \\
93 \%\end{array}$ & $\begin{array}{l}\text { Clostridium sp. Irt-JG1-73 } \\
\text { Clostridium sp. L1/6 } \\
\text { Clostridium sp. } 265 \mathrm{~b} \\
\text { Clostridium sp. } 44 \mathrm{a}-\mathrm{T} 5 \mathrm{zd}\end{array}$ & $\begin{array}{l}\text { AJ295661 } \\
\text { AY188846 } \\
\text { AY082450 } \\
\text { AY082483 }\end{array}$ & $62 \%$ & $\begin{array}{c}\text { Selenska-Pobell,2002 } \\
\text { Tamburini } \text { et al., } 2003 \\
\text { NP } \\
\text { NP }\end{array}$ \\
\hline
\end{tabular}


Tabela 5.9 (conclusão). Comparação de identidade para as UTOs de Bacteria dos reatores R1, R2 e R3 (Pb: pares de bases).

\begin{tabular}{|c|c|c|c|c|c|c|c|c|}
\hline Reator & UTO & $\begin{array}{c}N^{o} \\
\text { clones }\end{array}$ & $P b$ & Identidade & $\begin{array}{c}\text { Organismo } \\
\text { (como descrito no GenBank) }\end{array}$ & $\begin{array}{c}\text { Acesso } \\
\text { GenBank }\end{array}$ & $\begin{array}{c}\text { Abundância } \\
\text { (\%) }\end{array}$ & Referência \\
\hline $\mathrm{R} 2$ & 5 & 16 & 632 & $\begin{array}{l}94 \% \\
92 \% \\
94 \% \\
93 \% \\
\end{array}$ & $\begin{array}{l}\text { Clostridium sp. Irt-JG1-73 } \\
\text { Clostridium sp. L1/6 } \\
\text { Clostridium sp. 265b } \\
\text { Clostridium sp. 44a-T5zd }\end{array}$ & $\begin{array}{l}\text { AJ295661 } \\
\text { AY188846 } \\
\text { AY082450 } \\
\text { AY082483 }\end{array}$ & $32 \%$ & $\begin{array}{c}\text { Selenska-Pobell, } 2002 \\
\text { Tamburini et al., } 2003 \\
\text { NP } \\
\text { NP }\end{array}$ \\
\hline $\mathrm{R} 2$ & 2 & 1 & 614 & $\begin{array}{l}100 \% \\
100 \% \\
98 \% \\
\end{array}$ & $\begin{array}{c}\text { Acidaminobacter hydrogenoformans } \\
\text { Clostridium sp. BA-1 } \\
\text { Fusibacter paucivorans }\end{array}$ & $\begin{array}{l}\text { AF016691 } \\
\text { AB196728 } \\
\text { AF050099 } \\
\end{array}$ & $2 \%$ & $\begin{array}{c}\text { Stams e Hansen, } 1984 \\
\text { NP } \\
\text { Ravot et al, } 1999\end{array}$ \\
\hline $\mathrm{R} 2$ & 3 & 1 & 643 & $100 \%$ & uncultured Chlorobi bacterium & CU466692 & $2 \%$ & $\mathrm{NP}$ \\
\hline $\mathrm{R} 2$ & 4 & 1 & 618 & $99 \%$ & uncultured bacterium & EU137635 & $2 \%$ & Jones et al., 2008 \\
\hline R3 & 1 & 45 & 637 & $\begin{array}{l}95 \% \\
93 \%\end{array}$ & $\begin{array}{l}\text { Clostridium sp. L1/6 } \\
\text { Clostridium sp. } 265 \mathrm{~b}\end{array}$ & $\begin{array}{l}\text { AY188846 } \\
\text { AY082450 }\end{array}$ & $42 \%$ & $\begin{array}{l}\text { Tamburini et al., } 2003 \\
\text { NP }\end{array}$ \\
\hline R3 & 2 & 3 & 585 & $\begin{array}{l}92 \% \\
90 \% \\
\end{array}$ & $\begin{array}{l}\text { Clostridium sp. L1/6 } \\
\text { Clostridium sp. } 265 \mathrm{~b}\end{array}$ & $\begin{array}{l}\text { AY188846 } \\
\text { AY082450 }\end{array}$ & $3 \%$ & $\begin{array}{l}\text { Tamburini et al., } 2003 \\
\text { NP }\end{array}$ \\
\hline R3 & 7 & 44 & 631 & $\begin{array}{l}100 \% \\
100 \%\end{array}$ & $\begin{array}{l}\text { Clostridium sp. L1/6 } \\
\text { Clostridium sp. 265b }\end{array}$ & $\begin{array}{l}\text { AY188846 } \\
\text { AY082450 }\end{array}$ & $41 \%$ & $\begin{array}{c}\text { Tamburini et al., } 2003 \\
\text { NP }\end{array}$ \\
\hline R3 & 8 & 2 & 578 & $\begin{array}{l}100 \% \\
100 \%\end{array}$ & $\begin{array}{l}\text { Clostridium sp. L1/6 } \\
\text { Clostridium sp. } 265 \mathrm{~b}\end{array}$ & $\begin{array}{l}\text { AY188846 } \\
\text { AY082450 }\end{array}$ & $2 \%$ & $\begin{array}{l}\text { Tamburini et al., } 2003 \\
\text { NP }\end{array}$ \\
\hline R3 & 9 & 1 & 395 & $\begin{array}{l}85 \% \\
87 \% \\
\end{array}$ & $\begin{array}{l}\text { Clostridium sp. L1/6 } \\
\text { Clostridium sp. 265b }\end{array}$ & $\begin{array}{l}\text { AY188846 } \\
\text { AY082450 }\end{array}$ & $1 \%$ & $\begin{array}{l}\text { Tamburini et al., } 2003 \\
\text { NP }\end{array}$ \\
\hline R3 & 3 & 2 & 600 & $\begin{array}{l}94 \% \\
93 \% \\
92 \% \\
\end{array}$ & $\begin{array}{c}\text { Clostridium sp. BA-1 } \\
\text { Acidaminobacter hydrogenoformans } \\
\text { Fusibacter paucivorans }\end{array}$ & $\begin{array}{l}\text { AB196728 } \\
\text { AF016691 } \\
\text { AF050099 } \\
\end{array}$ & $2 \%$ & $\begin{array}{c}\text { NP } \\
\text { Stams e Hansen, } 1984 \\
\text { Ravot } \text { et al, } 1999 \\
\end{array}$ \\
\hline R3 & 4 & 1 & 576 & $92 \%$ & Pepstostreptococcaceae bacterium SK031 & $\mathrm{AB} 377177$ & $1 \%$ & NP \\
\hline R3 & 5 & 2 & 575 & $82 \%$ & uncultured bacterium & EU134986 & $2 \%$ & Elshahed et al., 2008 \\
\hline $\mathrm{R} 3$ & 6 & 1 & 601 & $\begin{array}{l}93 \% \\
92 \%\end{array}$ & $\begin{array}{c}\text { uncultured bacterium } \\
\text { Sphingobacterium sp. P-7 }\end{array}$ & $\begin{array}{l}\text { EU133686 } \\
\text { AM411964 }\end{array}$ & $1 \%$ & $\begin{array}{l}\text { Elshahed } \text { et al., } 2008 \\
\text { Shrestha et al., } 2007\end{array}$ \\
\hline R3 & 10 & 1 & 619 & $100 \%$ & Acidovorax caeni & AM084006 & $1 \%$ & Heylen et al., 2006 \\
\hline R3 & 11 & 1 & 530 & $96 \%$ & uncultured bacterium & EU137635 & $1 \%$ & Jones et al., 2008 \\
\hline
\end{tabular}


Garcia-Moyano et al. (2007) estudaram a diversidade microbiana na drenagem ácida de mina do Rio Tinto (Espanha) e os clones de sua biblioteca alinharam-se com as espécies Acidithiobacillus ferrooxidans, Leptospirillum ferrooxidans e Acidiphillum spp. $\mathrm{O} \mathrm{pH}$ das amostras de onde foram obtidas as sequências estava entre 2,0 e 3,0.

As condições ambientes dos isolados citados são muito semelhantes ao ambiente onde era coletada a drenagem ácida utilizada nesse trabalho. É muito provável que a presença desses clones na biblioteca do reator R1 seja resultado da população microbiana nativa da drenagem ácida. Como no reator R1 não foi realizada nenhum tratamento especial no afluente, o reator manteve as características do ambiente natural desses microrganismos, caracterizados principalmente pelo baixo $\mathrm{pH}$. Assim, a flora predominante nesse reator parece ter sido aquele natural dos ambientes de mineração e a manutenção desse ambiente mais extremo dentro do reator pode ter dificultado o estabelecimento de outras populações microbianas, inclusive as bactérias redutoras de sulfato, que eram de interesse para esse processo.

As UTOs 3, 4 e 11 alinharam-se com mais de 95\% de identidade com o gênero Acidithiobacillus e um clone de bactéria não cultivada. Os trabalhos que citam esses organismos (Vásquez e Espejo, 1997; Macalady et al., 2007) também obtiveram isolados de biofilmes de ambientes acidófilos. Os primeiros autores trabalharam com amostras de minas de cobre e os segundos, com biofilmes ácidos de paredes de cavernas.

A UTO 10 do reator R1 foi a única que apresentou clones pertencentes a outro gênero e alinharam-se com a espécie Acidobacterium capsulatum, que de acordo com Hirashi et al. (1995) apresenta pH ótimo em condições ácidas, alinharam-se também com um clone descrito por Jones et al. (2003) isolado de solo e com uma bactéria não cultivada descrita no trabalho de Chan et al. (2006). 
No RAHLF 2 e 3, os resultados obtidos com os clones desses reatores foram muitos distintos do RAHLF 1. As UTOs 1 e 5 do reator R2 e as UTOs 1, 2, 7, 8 e 9 do reator R3 alinharam-se com algumas linhagens de Clostridium sp. descritas na literatura. A linhagem descrita no trabalho de Tamburini et al. (2003) descrever uma bactéria pectinolótica, enquanto Selenska-Pobell (2002) refere-se a uma linhagem de Clostridium sp. encontrada em pilhas de rejeitos de minas de urânio. O gênero Clostridium apresenta grande diversidade fenotípica e os representantes desse gênero parecem ter capacidade de atuar em diferentes condições metabólicas. Como descrito anteriormente, o filo Firmicutes apresenta 13 grupos fenotípicos muito heterogêneos entre si e a classe Clostridia está presente em 8 desses grupos. Um desses grupos refere-se as bactérias que reduzem o sulfato e o sulfito e ocorrem em um único gênero, Desulfotomaculum.

Esse gênero em específico não foi incluído na árvore construída pelo software ARB, porém alguns trabalhos publicados recentemente na literatura propõem novas espécies do gênero Clostridium que realizam a redução do sulfato. Hernandéz-Eugenio et al. (2002) identificaram uma nova espécie de bactéria redutora de sulfato em grânulos de reator UASB e propuseram o nome de Clostridium thiosulfatireducens sp. nov. Essa espécie foi capaz de utilizar diferentes fonte de carbono e gerar acetato, $\mathrm{CO}_{2}$ e sulfeto como produtos finais. $\mathrm{Ma}$ et al. (2008) identificou uma espécie de bactéria redutora de sulfato altamente relacionada em termos filogenéticos ao gênero Clostridium, com o nome provisório de Clostridium bifermentans H1. Sallam e Steinbüchel (2009) propuseram uma nova espécie, denominada Clostridium sufidogenesis sp. nov., que é capaz de reduzir o sulfato e o tiossulfato em condições mesofílicas. A espécie foi isolada do sedimento de lagoas. 
A UTO 2 do reator R2 e a UTO 3 do reator R3 também alinharam-se com uma linhagem de Clostridium sp., porém apresentaram identidade elevada (100\% para reator R2) com Acidaminobacter hydrogenomorfans, uma bactéria isolada por Stams e Hansen (1994) em reatores contendo culturas mistas de arqueias metanogênicas e bactérias redutoras de sulfato. Essas UTOs também apresentaram identidade com a espécie Fusibacter paucivorans, uma nova espécie descrita em Ravot et al. (1999) como uma bactéria redutora de tiosulfato e capaz de metabolizar diferentes fontes de matéria orgânica e produzir acetato, $\mathrm{CO}_{2}$ e $\mathrm{H}_{2}$ como produtos de fermentação anaeróbia. Está relacionada filogeneticamente a ordem Clostridiales e isso pode explicar a identidade dessas UTOs com as duas espécies. Dentre todos os clones estudados para os reatores R2 e R3, aqueles pertencentes a essas UTOs foram os que apresentaram as características mais próximas ao metabolismo da redução de sulfato, processo esse que ocorreu de maneira eficiente em ambos os reatores.

As UTOs 2 e 3 do reator R2 relacionaram-se a clones de bactérias não cultivadas, porém vale ressaltar que no filo Chlorobi estão presentes bactérias capazes de utilizar o sulfeto como doador de elétrons e acumular enxofre elementar.

A UTO 4 do reator R3 alinhou-se com a espécie Pepstostreptococcaceae bacterium, não publicada na literatura, mas descrita no GenBank como um isolado de reator metanogênico.

As UTOs 5, 6 e 11 alinharam-se com clones descritos na literatura como isolados de solo de bactérias não cultivadas e com o gênero Sphingobacterium sp., descrito como isolado de solos contaminados, enquanto a UTO 10 alinhou-se com a espécie Acidovorax caeni, que segundo os trabalhos de Heylen et al. (2006) é uma bactéria com atividade desnitrificante e que foi isolada de sistemas de lodos ativados. 


\subsubsection{Balanço de massa dos reatores RAHLF}

Com os dados de eficiência média de remoção de DQO e sulfato e concentração média de ácido acético do efluente subtraída da concentração afluente dos reatores estudados (Tabela 5.10), tentou-se estimar os principais caminhos metabólicos microrganismos redutores de sulfato e a presença de outras vias de utilização da DQO que não a redução do sulfato. Na análise dos reatores não serão considerados os períodos de partida dos reatores R1 e R3 e nem o período de recirculação do reator R3 (fase III).

Tabela 5.9. Dados de eficiência de remoção de DQO e sulfato e concentrações médias de ácido acético na operação dos reatores R1, R2 e R3.

\begin{tabular}{|c|c|c|c|c|c|}
\hline Reator & Fase & $\begin{array}{l}\text { Carga DQO } \\
\text { removida } \\
\left(\mathrm{mg} \mathrm{l}^{-1} \text { dia }^{-1}\right)\end{array}$ & $\begin{array}{l}\text { Carga etanol } \\
\text { removida } \\
\left(\mathrm{mg} \mathrm{l}^{-1} \text { dia }^{-1}\right)\end{array}$ & $\begin{array}{c}\mathrm{Carga}_{\mathrm{SO}_{4}}{ }^{2-} \\
\text { removida } \\
\left(\mathrm{mg} \mathrm{l}^{-1} \text { dia }^{-1}\right)\end{array}$ & $\begin{array}{c}\text { Ácido acético } \\
\text { [Af -Ef] } \\
\left(\mathrm{mg} \mathrm{l}^{-1}\right)\end{array}$ \\
\hline \multirow{2}{*}{$\mathrm{R} 1$} & I & 290,0 & 139,0 & 240,0 & 208,0 \\
\hline & II & 540,0 & 260,0 & 190,0 & 10,0 \\
\hline \multirow{2}{*}{$\mathrm{R} 2$} & I & 360,0 & 173,0 & 250,0 & 240,0 \\
\hline & II & 200,0 & 96,0 & 120,0 & 11,0 \\
\hline \multirow{2}{*}{ R3 } & I & 190,0 & 91,0 & 240,0 & 3,0 \\
\hline & II & 200,0 & 96,0 & 245,0 & 7,0 \\
\hline
\end{tabular}

Para o balanço de massa dos reatores, serão utilizadas as equações 5.2 e 5.4.

$0.5 \mathrm{SO}_{4}{ }^{2-}+\mathrm{CH}_{3} \mathrm{CH}_{2} \mathrm{OH} \rightarrow \mathrm{CH}_{3} \mathrm{COO}^{-}+0.5 \mathrm{H}_{2} \mathrm{~S}+\mathrm{H}_{2} \mathrm{O}$

$\Delta \mathrm{G}^{\mathrm{o}}=-69.2 \mathrm{~kJ} / \mathrm{mol}$ etanol

$1.5 \mathrm{SO}_{4}{ }^{2-}+\mathrm{CH}_{3} \mathrm{CH}_{2} \mathrm{OH}+\mathrm{H}^{+} \rightarrow 2 \mathrm{HCO}_{3}{ }^{-}+1.5 \mathrm{H}_{2} \mathrm{~S}+\mathrm{H}_{2} \mathrm{O}$

$\Delta \mathrm{G}^{\mathrm{o}}=-162.28 \mathrm{~kJ} / \mathrm{mol}$ etanol 


\subsubsection{Resultados do balanco de massa para o reator R1}

A conversão da DQO oxidada em termos de sulfato reduzido na fase I do reator R1 resultou na remoção teórica, de acordo com as equações 5.2 e 5.4, de $137,0 \mathrm{mg} \mathrm{SO}_{4}^{-2} \mathrm{l}^{-1} \mathrm{dia}^{-1}$ no caso da oxidação incompleta da matéria orgânica a acetato e em 435,0 $\mathrm{mg} \mathrm{SO}_{4}^{-2} 1^{-1}$ dia $^{-1}$ no caso da oxidação completa do etanol a gás carbônico e água.

Considerando somente a presença da via oxidativa incompleta, nota-se que a redução de sulfato observada foi superior a redução máxima que essa via poderia proporcionar. Porém, caso a oxidação completa fosse a única presente, a redução de sulfato observada seria $55 \%$ do total possível.

Como foi detectada uma quantidade considerável de acetato nessa fase do reator, é sabido que a via oxidativa completa não seria a única presente. Pela via oxidativa incompleta, a quantidade máxima de acetato produzido seria de $178 \mathrm{mg}$ acetato $\mathrm{l}^{-1} \mathrm{dia}^{-1}$. Entretanto, as análises durante a fase I desse reator resultaram em uma carga média de 208,0 $\mathrm{mg}_{\text {acetato }} \mathrm{1}^{-1}$ dia $^{-1}$. Assim, parece que a redução do sulfato seria responsável por $85 \%$ do acetato gerado, enquanto os outros $15 \%$ seriam resultado da oxidação da matéria orgânica realizada por outros microrganismos ou ainda pelas próprias BRS, porém, utilizando outros receptores de elétrons.

Lovley et al. (1993a) demonstraram que alguns microrganismos que utilizam sulfato ou $\mathrm{S}^{0}$ como receptor de elétrons, também podem reduzir o $\mathrm{Fe}(\mathrm{III}), \mathrm{Mn}(\mathrm{IV})$ e U(VI). De acordo com os estudos desses autores, a redução do Fe (III) e do U(IV) não seria resultado de redução química por sulfeto, por exemplo, e sim realizada enzimaticamente por bactérias do gênero Desulfovibrio. Em experimentos com D. vulgaris (Lovley et al., 1993b) foi detectado que o mecanismo de redução do $\mathrm{Fe}(\mathrm{III})$, assim como de outros metais, ocorre no citocromo $c 3$ 
mediado por uma hidrogenase. Quando elétrons são oferecidos ao citocromo $c 3$ na presença de hidrogenase e $\mathrm{H}_{2}$, o Fe(III) oxidado é reduzido a $\mathrm{Fe}(\mathrm{II})$ solúvel com formação de magnetita e siderita. No caso do U(IV), quando reduzido a U(IV), ocorre a precipitação de uraninita.

De acordo com os resultados na fase I, fica muito evidente que nessas condições, a via oxidativa incompleta foi a preferencial para as redutoras de sulfato.

Quando se analisa a fase II do reator R1 com relação às equações 5.2 e 5.4, percebe-se também uma diferença nas cargas removidas teóricas e naquelas observadas. No caso da carga de sulfato removida, esta deveria ser $271,0 \mathrm{mg} \mathrm{SO}_{4}^{-2} 1^{-1} \mathrm{dia}^{-1}$ pela via incompleta de oxidação e $813,0 \mathrm{mg} \mathrm{SO}_{4}^{-2} 1^{-1}$ dia $^{-1}$ através da via completa de oxidação do etanol. Esses valores ficaram além do observado, que foi de $190 \mathrm{mg} \mathrm{SO}_{4}^{-2} \mathrm{l}^{-1} \mathrm{dia}^{-1}$. Como a quantidade de acetato gerada nessa fase foi extremamente baixa, 10,0 mg acetato $\mathrm{l}^{-1} \mathrm{dia}^{-1}$, é difícil acreditar que a via oxidativa incompleta fosse predominante nessa fase reator.

Vale lembrar, porém, que muitos autores relatam que na competição entre arqueias metanogênicas e as bactérias redutoras de sulfato, a relação $\mathrm{DQO} / \mathrm{SO}_{4}{ }^{-2}$ é um parâmetro importante no favorecimento de um ou outro grupo. Com o aumento da razão $\mathrm{DQO} / \mathrm{SO}_{4}{ }^{2-}$ as reações de metanogênese prevalecem sobre a sulfetogênese, enquanto com a proximidade dessa razão aos valores estequiométricos, nota-se aumento da atividade das BRS de da quantidade de $\mathrm{H}_{2} \mathrm{~S}$ produzido (Mizuno et al., 1994).

Como o pH de operação foi distante do pH ótimo das arqueias metanogênicas, outros grupos de microrganismos poderiam ainda estar oxidando o excesso de etanol oferecido nessa fase do reator R1, como discutido na Figura 5.15.

Há ainda que se considerar que a carga removida de etanol tenha promovido uma redução maior de sulfato, porém parte do sulfeto gerado poderia ter sido oxidado novamente a sulfato por bactérias quimiolitoautotróficas oxidadoras de enxofre. Esse grupo de bactérias, 
representado principalmente pelo gênero Acidithiobacillus, é comumente encontrado em ambientes de mineração, sendo o principal responsável pela geração de drenagem ácida de minas. São microrganismos acidófilos e aeróbios, mas que podem tolerar ambientes com concentrações muitos baixas de oxigênio (Baker e Banfield, 2003).

Os exames de biologia molecular confirmaram a presença extensa de microrganismos do gênero Acidithiobacillus (95\% dos clones), que são os principais responsáveis por processos de oxidação de sulfetos metálicos a enxofre elementar ou a sulfato. O ambiente do reator R1 manteve-se muito parecido com as características encontradas na formação de drenagem ácida, exceto pela redução do oxigênio presente. Entretanto, esses microrganismos são capazes de sobreviver em ambientes micro-aerofílicos e, portanto, puderem continuar se desenvolvendo no reator em estudo. Visualmente, foi notado acúmulo de substância amarelada no leito do reator, principalmente na porção final (Figura 5.45). Provavelmente, essa substância corresponde a enxofre elementar.

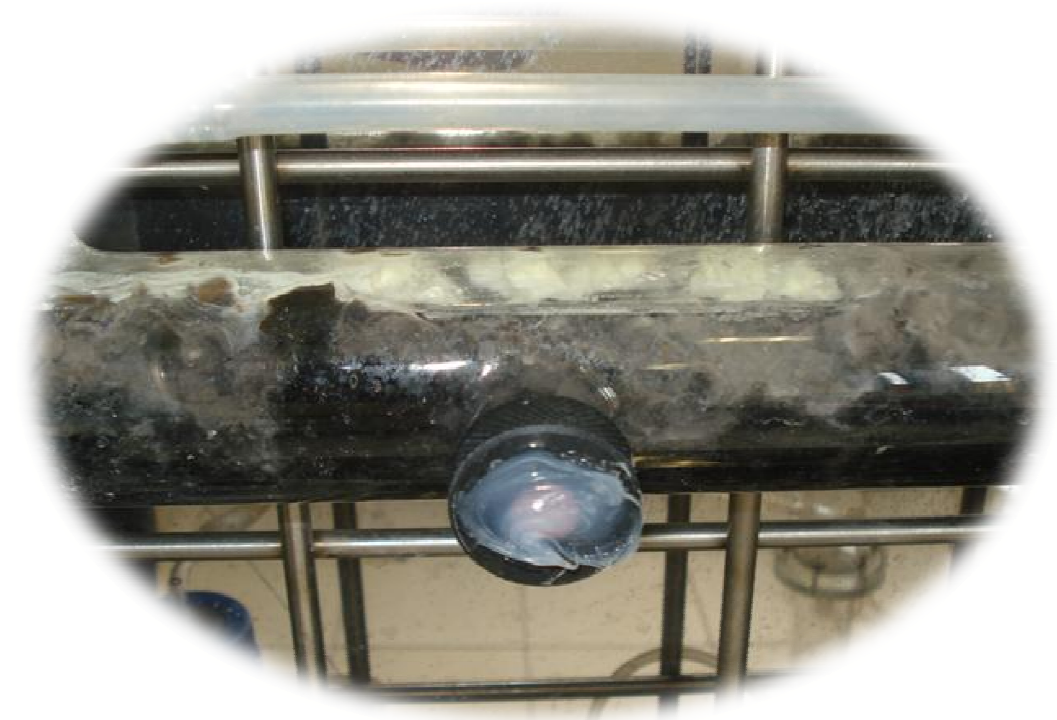

Figura 5.45. Acúmulo de $\mathrm{S}^{0}$ no leito do reator R1. 
O que se percebe nesse reator é que a via dissimilatória incompleta foi mais utilizada na fase I do que na fase II, com uma produção muito mais elevada de acetato na primeira fase do reator.

\subsubsection{Resultados do balanço de massa para o reator R2}

A remoção média de DQO na fase I do reator R2 foi de $360 \mathrm{mg}$ DQO $\mathrm{l}^{-1} \mathrm{dia}^{-1}$. Se oxidada completamente a $\mathrm{CO}_{2}$ e $\mathrm{H}_{2} \mathrm{O}$, essa quantidade em concentração de etanol seria suficiente para promover uma redução de 541,0 $\mathrm{mg} \mathrm{SO}_{4}{ }^{-2} 1^{-1} \mathrm{dia}^{-1}$, valor bem superior ao observado, que foi de $250 \mathrm{mg} \mathrm{SO}_{4}^{-2} \mathrm{l}^{-1} \mathrm{dia}^{-1}$.

Entretanto, considerando-se que uma quantidade significativa de ácido acético foi detectada na corrente efluente, poder-se-ia inferir que a oxidação incompleta da matéria orgânica estivesse mais fortemente presente nessa fase do reator. Sendo assim, a carga de sulfato removida seria de $180 \mathrm{mg} \mathrm{SO}_{4}{ }^{-2} \mathrm{l}^{-1} \mathrm{dia}^{-1}$. Esse valor está abaixo da carga removida nessa fase do reator e, provavelmente, a via incompleta de oxidação da DQO não seria a única presente. A carga de ácido acético detectada na corrente efluente foi em média de $241,0 \mathrm{mg}$ acetato $1^{-1} \mathrm{dia}^{-1}$. Caso essa quantidade de acetato fosse resultante apenas da oxidação incompleta, seria esperada uma carga $222,0 \mathrm{mg}$ acetato $\mathrm{l}^{-1} \mathrm{dia}^{-1}$. É possível que neste reator, em função da elevação do $\mathrm{pH}$ para mais próximo da neutralidade, outras comunidades tenham se estabelecido e utilizado o etanol como doador de elétrons, resultando em acúmulo de acetato.

Como apresentado anteriormente, as BRS dividem-se em dois grupos: as dissimilatórias completas e as dissimilatórias incompletas. O primeiro grupo é capaz de utilizar a fonte de carbono de maneira completa, até $\mathrm{CO}_{2}$ e $\mathrm{H}_{2} \mathrm{O}$, enquanto o segundo grupo 
oxida parcialmente a matéria orgânica apenas até acetato. As bactérias redutoras de sulfato completas normalmente utilizam acetato como substrato, entretanto, sabe-se que inúmeras espécies podem crescer em substratos diferenciados, como etanol, ácidos voláteis de cadeia curta e compostos aromáticos (Widdel, 1988 apud Muyzer e Stams, 2008). Supondo-se que nesse reator ambas estivessem presentes, o resultado seria uma redução na quantidade de sulfato reduzida, visto que quando o produto final da oxidação do etanol é o ácido acético, o número de elétrons transportados ao receptor final de elétrons é cerca de três vezes inferior ao que seria transportado se o produto final da oxidação fosse $\mathrm{CO}_{2}$ e $\mathrm{H}_{2} \mathrm{O}$.

Kolmert e Johnson (2001) apresentam resultados semelhantes ao do reator R2. Em um estudo conduzido com diferentes fontes de carbono, os autores notaram que na presença do etanol, o reator inoculado com biomassa acidofílica de BRS teve como principal via de oxidação da matéria orgânica, a dissimilação incompleta, com praticamente todo o etanol consumido sendo levado a ácido acético.

Durante a fase II do reator R2, com a mudança na corrente de alimentação com redução da carga de sulfato aplicada ao reator, percebe-se uma alteração no comportamento da oxidação da matéria orgânica, detectado pela queda a valores quase nulos de ácido acético no efluente.

Entretanto, se a via de oxidação completa fosse a que estivesse presente na fase II, a carga de sulfato removida deveria ser de $300 \mathrm{mg} \mathrm{SO}_{4}^{-2} \mathrm{l}^{-1} \mathrm{dia}^{-1}$, acima do que foi detectado. Já no caso da oxidação incompleta, seria esperado uma redução teórica de sulfato de $100 \mathrm{mg}$ $\mathrm{SO}_{4}^{-2} \mathrm{l}^{-1} \mathrm{dia}^{-1}$, que está um pouco abaixo do detectado $\left(120 \mathrm{mg} \mathrm{SO}_{4}{ }^{-2} \mathrm{l}^{-1} \mathrm{dia}^{-1}\right)$. Nesse caso, seria essencial que as duas vias de utilização da matéria orgânicas estivessem presentes para reduzir a carga removida de sulfato observada. 
Considerando, porém, que quase nenhum acetato foi detectado na corrente efluente nessa fase, é provável que o sulfato tenha sido reduzido estequiometricamente de acordo com a equação de oxidação completa da matéria orgânica, porém parte do sulfeto gerado tenha sido oxidado por bactérias oxidadoras de enxofre ou que o etanol estivesse sendo utilizado por outros grupos de microrganismos. Nessa fase do reator $\mathrm{R} 2$, o $\mathrm{pH}$ estava mais favorável ao estabelecimento de outras comunidades microbianas. O inóculo utilizado nesses estudos é proveniente de um reator anaeróbio com longo tempo de operação e apresenta grânulos com grande diversidade microbiana (Hirasawa et al., 2008), resultando em maior capacidade de adaptação às inúmeras condições impostas.

\subsubsection{Resultados do balanço de massa para o reator R3}

Como não foi praticamente detectado ácido acético no efluente do reator R3 na fase I, tem-se que a carga de DQO removida nessa fase, se oxidada completamente a $\mathrm{CO}_{2}$ e $\mathrm{H}_{2} \mathrm{O}$ seria suficiente para promover uma redução de $285 \mathrm{mg} \mathrm{SO}_{4}^{-2} \mathrm{l}^{-1} \mathrm{dia}^{-1}$. Entretanto, a eficiência obtida na análise dos dados foi cerca de $15 \%$ inferior ao que seria possível de ser conseguido.

Essa mesma observação foi feita por Tsukamoto et al. (2004) em um estudo para tratamento de drenagem ácida de mina em reatores de coluna. Os autores utilizaram etanol como fonte de energia, em uma concentração suficiente para reduzir $50 \%$ do sulfato presente no afluente. Entretanto, a redução máxima obtida foi de $44 \%$, ou seja, $88 \%$ do total esperado para aquele fluxo de elétrons.

Algumas são as possibilidades que podem explicar essa menor redução de sulfato e que, provavelmente, ocorrem conjuntamente nesse reator. Tang et al. (2009) citam que o íon férrico e o urânio VI poderiam atuar como receptores de elétrons para algumas espécies de 
BRS. Considerando-se que a água residuária em questão provém de um local de mineração de urânio e com rochas ricas em sulfeto férrico oxidado, seria muito provável que estes elementos estivessem utilizando parte dos elétrons provenientes da oxidação do etanol e, dessa forma, impedindo que o íon sulfato funcionasse como único receptor de elétrons.

A segunda possibilidade envolve a presença de bactérias fermentativas nesse sistema. As bactérias fermentativas oxidam parcialmente a fonte de carbono até o íon acetato. Imagens de microscopia ótica comum revelaram a presença desses microorganismos nos reatores em estudo (Figura 5.19). Essa competição pela fonte de energia resultaria em menor disponibilidade de elétrons para as bactérias redutoras de sulfato e, assim, a quantidade de sulfato reduzida seria inferior àquela esperada em função da oxidação da matéria orgânica.

$\mathrm{Na}$ fase II de operação do reator R3 também não foi detectado ácido acético no efluente e supõe-se que a principal via de oxidação do etanol tenha sido a completa. Assim para a carga de DQO removida nessa fase, se oxidada completamente a $\mathrm{CO}_{2}$ e $\mathrm{H}_{2} \mathrm{O}$, seria possível uma redução de $300 \mathrm{mg} \mathrm{SO}{ }_{4}^{-2} \mathrm{l}^{-1} \mathrm{dia}^{-1}$, superior ao que foi detectado na corrente efluente.

Os fatores que poderiam explicar essa diferença são aqueles já citados, como a presença de outros receptores de elétrons ou de bactérias fermentativas. Na fase II, entretanto, como o aporte de elétrons estava em excesso com relação a estequiometria da redução do sulfato é, mais provável, que outros grupos bacterianos tenham utilizado parte dessa maior quantidade de doador de elétrons. Nota-se que a na fase I, a quantidade de sulfato removida foi $85 \%$ do total esperado, enquanto na fase II foi de $80 \%$. O oferecimento de maior quantidade de matéria orgânica com o objetivo de estimular a redução de todo o sulfato presente não resultou em aumento da remoção do sulfato. Esse mesmo comportamento foi observado no reator $\mathrm{R} 1$, quando $\mathrm{o}$ aumento da relação $\mathrm{DQO} / \mathrm{SO}_{4}{ }^{2-}$ desfavoreceu o 
metabolismo das redutoras de sulfato. Como citado por Lens et al. (1998), acima da relação estequiométrica de 0,67 , é provável que as BRS não consigam se sobrepor às metanogênicas, por exemplo.

\subsection{Ensaios no Reator Anaeróbio de Fluxo Ascendente e Manta de Lodo - UASB}

\subsubsection{Etapa A de operação dos reatores UASB}

Na etapa A, três reatores UASB foram operados com diferentes volumes de manta de lodo (U1: $156 \mathrm{ml}, \mathrm{U} 2: 312 \mathrm{ml}$ e U3: $468 \mathrm{ml}$ ). A quantidade inicial de lodo granular inoculada no reator U1 foi definida impondo ao reator UASB a mesma carga orgânica mássica que foi imposta aos outros reatores deste projeto. Segundo este critério, dos $840 \mathrm{ml}$ do volume total do reator, $156 \mathrm{ml}$ seria ocupado por lodo granular. Considerando que este lodo apresenta $32,85 \mathrm{~g} \mathrm{STV}^{-1}$, o volume de inóculo utilizado propiciou uma concentração celular de 7,49 $\mathrm{g}$ STV por litro de volume útil do reator.

Os reatores foram operados separadamente, em períodos que variaram de 45 a quase 80 dias, dependendo do reator. A alimentação de todos os reatores era constituída de drenagem bruta, sem diluição e sem correção de $\mathrm{pH}$, adicionada de etanol na relação $\mathrm{DQO} / \mathrm{SO}_{4}{ }^{2-}$ estequiométrica de 0,67 .

A Figura 5.46 apresenta o comportamento do $\mathrm{pH}$ efluente para as três condições estudadas. 


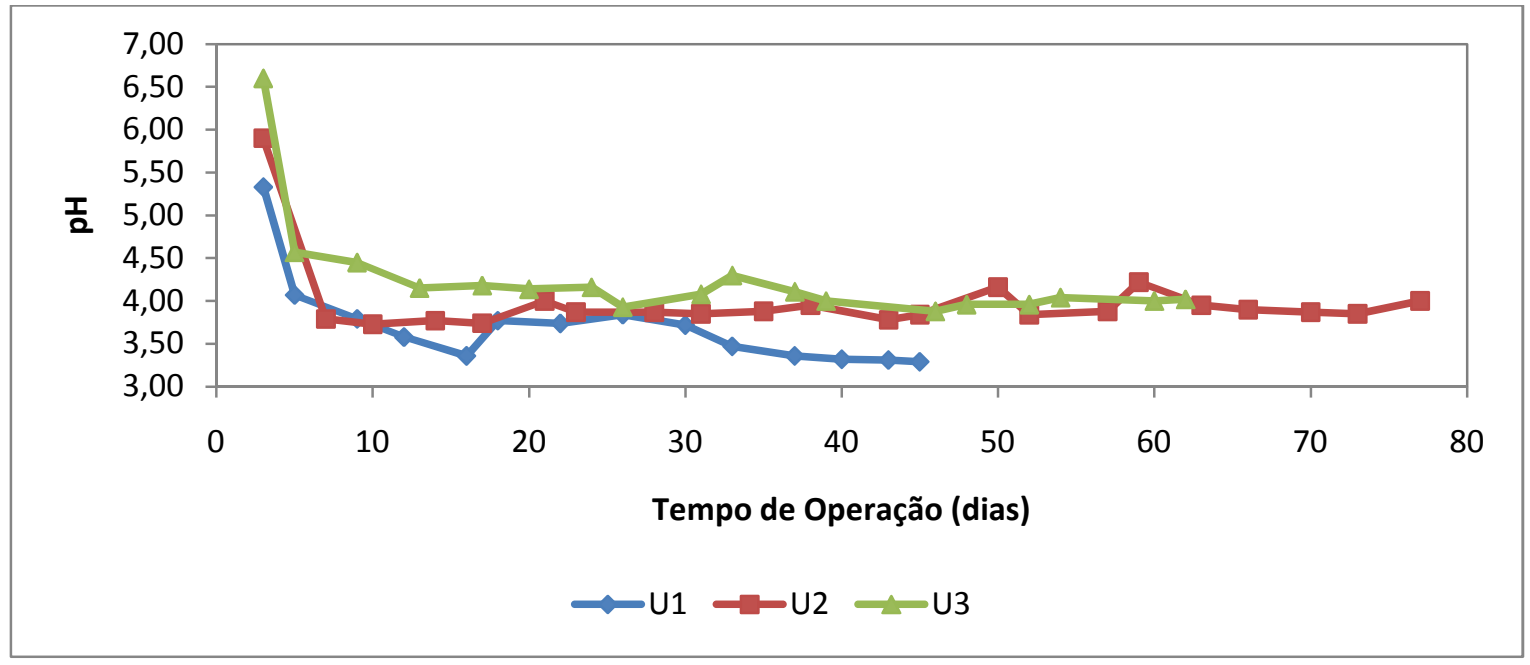

Figura 5.46. Comportamento do $\mathrm{pH}$ efluente para os reatores U1, U2 e U3.

Com relação ao $\mathrm{pH}$ efluente, nota-se pouca diferença entre os reatores analisados. É possível perceber que o aumento do volume da manta de lodo nos reatores U2 e U3 promoveu um ligeiro aumento no $\mathrm{pH}$ efluente, comparado ao reator U1. Comparativamente ao reator RAHLF 1 que também recebeu drenagem bruta, os valores de $\mathrm{pH}$ efluente estão bem parecidos, o que se torna mais um indicativo da dificuldade de se estabelecer condições favoráveis para o metabolismo da biomassa.

As eficiências de remoção de DQO, entretanto, mostraram algumas diferenças no comportamento desses reatores (Figura 5.47). 


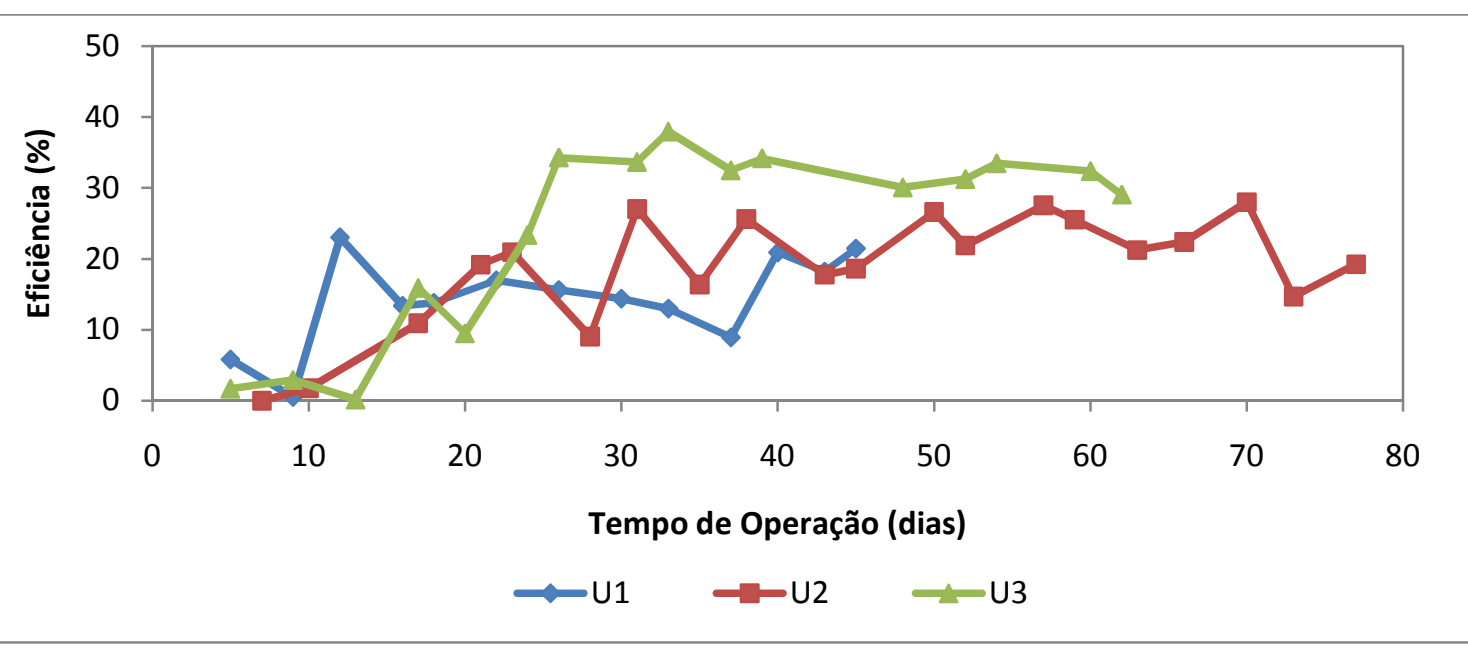

Figura 5.47. Eficiências de remoção de DQO para os reatores U1, U2 e U3.

Após cerca de 20 dias de operação, os reatores UASB apresentaram certa estabilidade com remoções de DQO proporcionais ao volume da manta de lodo do reator. O reator U1 apresentou remoção média de $14,3 \% \pm 6,4 \%$, com uma carga orgânica média removida de $0,14 \mathrm{~g} \mathrm{DQO}^{-1} \operatorname{dia}^{-1}$. A remoção média no reator U2 foi de $18,7 \% \pm 8,0 \%$ e a carga orgânica média removida foi de $0,19 \mathrm{~g}$ DQO ${ }^{-1} \mathrm{dia}^{-1}$. Para o reator U3, a eficiência média foi de 33,3\% $\pm 10,1 \%$ e a carga orgânica média removida foi de $0,28 \mathrm{~g}$ DQO $1^{-1} \mathrm{dia}^{-1}$.

A utilização de um volume de lodo que ocupava mais da metade do volume útil do reator contribuiu para uma grande melhora na eficiência da remoção de DQO. Essa quantidade de manta de lodo aproximou o reator UASB de um reator de leito fixo e, em função do seu pequeno diâmetro, de um fluxo que se aproximou do fluxo pistonado. Portanto, era de se esperar que a biomassa, agora com condições de se estratificar ao longo do leito, conseguisse utilizar melhor a fonte de elétrons disponível, principalmente nas porções mais distantes da entrada do reator.

Os resultados do reator U3 foram muito semelhantes ao do reator R1, que apresentou remoção média de DQO de 32,1\% e de carga orgânica de 0,29g DQO $1^{-1}$ dia $^{-1}$. Esses reatores apresentavam características muito parecidas, como o tempo de detenção hidráulica, a mesma 
concentração de sulfato afluente, o mesmo tipo de inóculo e a presença de um leito estratificado. A maior diferença estava na organização da biomassa, que no reator U3 estava em grânulos e no reator R1 estava aderida a espuma de poliuretano. Entretanto, isto parece ter pouco influenciado nos resultados desses reatores.

A Figura 5.48 mostra os valores de eficiências de remoção de sulfato obtidos para os reatores UASB em estudo.

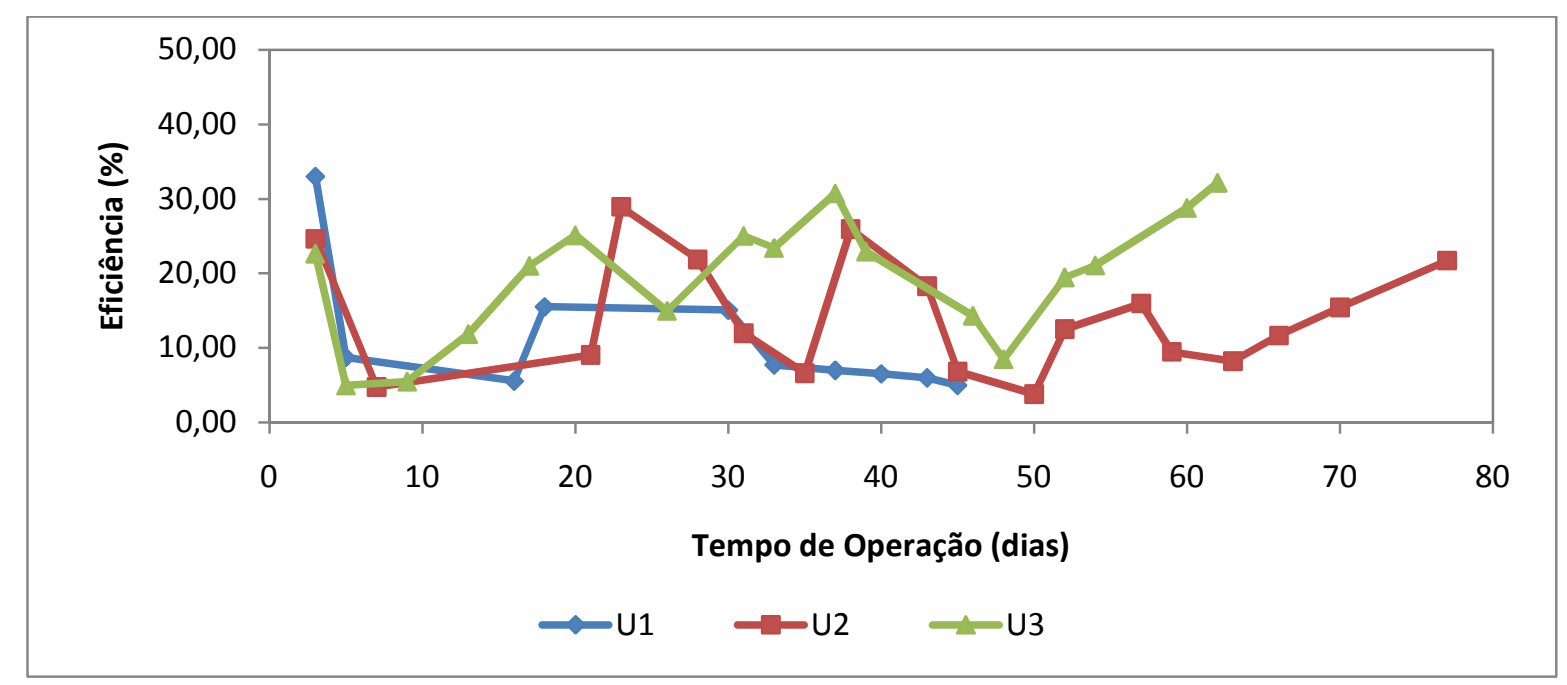

Figura 5.48. Eficiências de remoção de sulfato para os reatores U1, U2 e U3.

Diferentemente da DQO, a remoção de sulfato não apresentou nenhum período mais estável durante toda a operação dos reatores. Esse comportamento também foi observado em relação ao reator R1, que apresentou certa estabilidade na remoção de DQO, porém nenhum período mais estável de remoção de sulfato quando operado na relação $\mathrm{DQO} / \mathrm{SO}_{4}{ }^{2-}$ de 0,67 .

A remoção média de sulfato para o reator U1 foi $11,0 \% \pm 8,3 \%$ e a carga de sulfato média removida foi de $0,09 \mathrm{~g} \mathrm{SO}_{4}{ }^{2-}{ }^{-1} \mathrm{dia}^{-1}$. Para o reator U2, a eficiência média ficou em $14,3 \% \pm 7,7 \%$, com uma carga de sulfato removida de $0,24 \mathrm{~g} \mathrm{SO}_{4}{ }^{2-} 1^{-1} \mathrm{dia}^{-1}$. No reator U3, a 
eficiência média ficou em $24,4 \% \pm 11,7 \%$ e a carga de sulfato removida foi de $0,30 \mathrm{~g} \mathrm{SO}_{4}{ }^{2-} \mathrm{l}^{-1}$ $\operatorname{dia}^{-1}$ em média.

Apesar da instabilidade do processo sulfetogênico, o reator U3 apresentou ligeira melhora na eficiência de remoção de sulfato quando comparado ao reator RAHLF 1, que resultou em uma eficiência média de remoção de sulfato de $17,3 \%$ e de carga de sulfato de $0,23 \mathrm{~g} \mathrm{SO}_{4}{ }^{2-} 1^{-1} \mathrm{dia}^{-1}$.

A Figura 5.49 apresenta os resultados das análises de sulfeto efluente para os reatores UASB com diferentes volumes de manta de lodo.

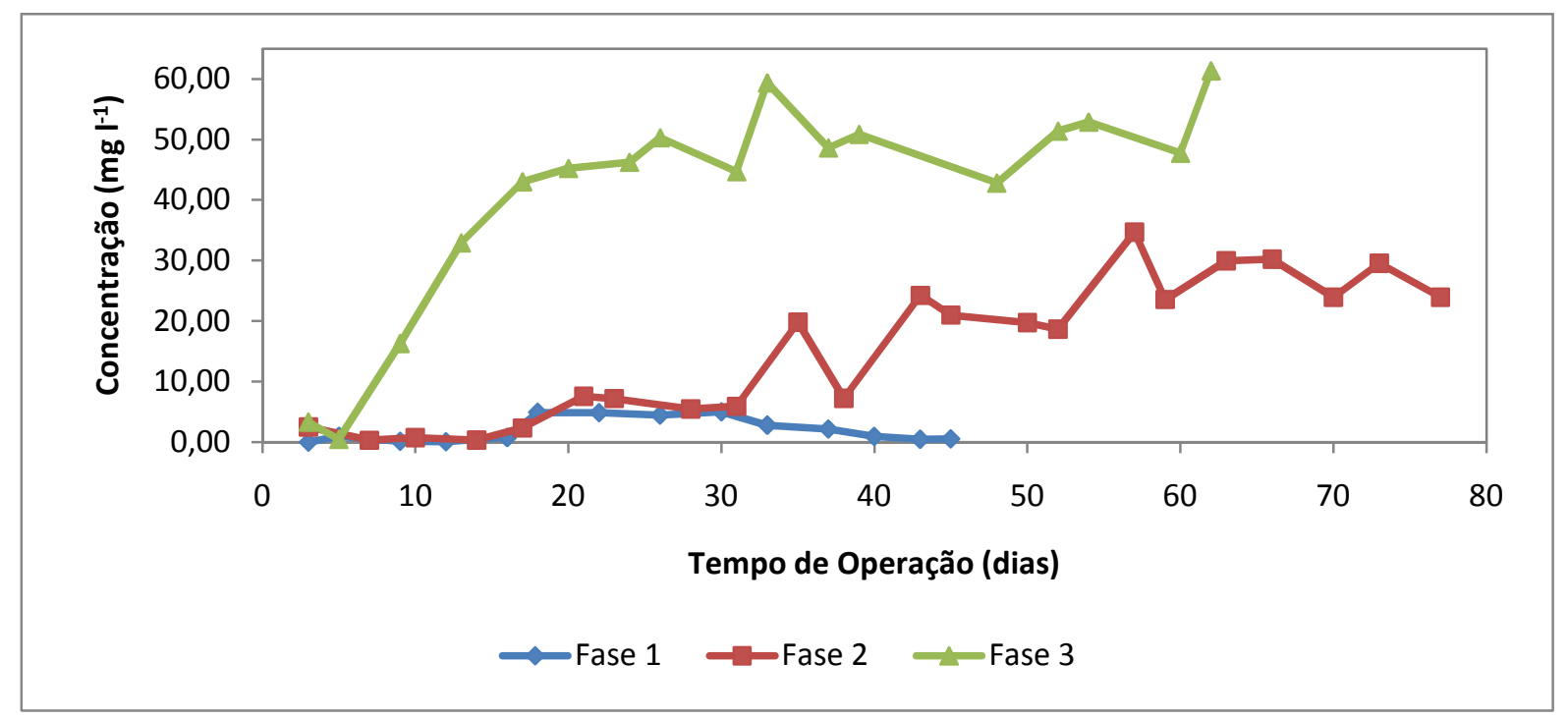

Figura 5.49. Concentrações de sulfeto efluente nos reatores U1, U2 e U3.

As análises de sulfeto dos reatores U1, U2 e U3 apresentaram diferenças significativas, refletindo diretamente a melhora do processo sulfetogênico com o aumento do volume da manta de lodo. No reator U1, a produção média ficou em $2,1 \mathrm{mg} \mathrm{l}^{-1} \pm 1,9$, enquanto para o reator $\mathrm{U} 2$, a média subiu para $15,4 \mathrm{mg}^{-1} \pm 11,5$. Para o reator $\mathrm{U} 3$, os valores médios de produção de sulfeto estiveram em 45,8 $\mathrm{mg}^{-1} \pm 18,4$. Esses valores estiveram 
abaixo do esperado em termos de estequiometria da remoção de sulfato, porém foram adicionais às análises de melhora de eficiência dos reatores com o aumento progressivo da quantidade de biomassa granular.

\subsubsection{Etapa B de operação do reator UASB}

\subsubsection{Análises de monitoramento}

As variáveis analisadas nesse reator foram semelhantes às analisadas no reator R3, que apresentou melhor desempenho na remoção de sulfato e de DQO, para que fosse possível estabelecer uma comparação entre os tipos de reator. Neste reator UASB, utilizou-se a quantidade de inóculo que apresentou melhor resultado dentre os 3 reatores anteriores, ou seja, $468 \mathrm{ml}$ de lodo granular. Para essa etapa, essa quantidade de inóculo correspondeu a uma concentração de 34,68g de STV por litro de volume útil do reator.

A análise dos metais em solução presentes na drenagem ácida de minas foi realizada no afluente e efluente do UASB, porém, como para os RAHLF, os resultados encontrados no efluente foram muito inconsistentes, provavelmente, devido aos inúmeros processos de adsorção, desorção, complexação e reações de oxi-redução que parecem ter ocorrido nesses reatores. Optou-se, portanto, em se apresentar apenas os resultados dos metais em solução no afluente dos reatores, com o objetivo de auxiliar a discussão dos resultados obtidos com os outros parâmetros de monitoramento.

A Tabela 5.11 apresenta os resultados para os metais $\mathrm{Cr}, \mathrm{Cu}, \mathrm{Ni}, \mathrm{Cd}, \mathrm{Mn}$ e $\mathrm{Zn}$ encontrados no afluente do reator UASB. 
Tabela 5.10. Concentração de metais no afluente do reator UASB.

\begin{tabular}{cccccccc}
\hline Fase Concentração $\left(\mathbf{m g ~ l}^{\mathbf{1}}\right)$ & $\mathbf{C r}$ & $\mathbf{C u}$ & $\mathbf{N i}$ & $\mathbf{C d}$ & $\mathbf{M n}$ & $\mathbf{Z n}$ \\
\hline \multirow{4}{*}{ I } & Média & 0,056 & 0,007 & 0,152 & 0,062 & 17,920 & 4,872 \\
& Desvio Padrão & 0,077 & 0,010 & 0,071 & 0,027 & 1,123 & 0,413 \\
& Média & 0,037 & 0,010 & 0,108 & 0,035 & 18,020 & 2,792 \\
& Desvio Padrão & 0,042 & 0,013 & 0,034 & 0,017 & 4,473 & 1,729 \\
\hline \multirow{4}{*}{ II } & Média & 0,264 & 0,005 & 0,251 & 0,079 & 57,113 & 4,253 \\
& Desvio Padrão & 0,090 & 0,009 & 0,013 & 0,030 & 85,978 & 0,099 \\
& Média & 0,040 & 0,000 & 0,185 & 0,075 & 8,838 & 1,820 \\
& Desvio Padrão & 0,050 & 0,000 & 0,023 & 0,032 & 8,089 & 1,428 \\
\hline \multirow{4}{*}{ III } & Média & 0,062 & 0,032 & 0,204 & 0,070 & 60,500 & 11,073 \\
& Desvio Padrão & 0,030 & 0,022 & 0,052 & 0,043 & 3,615 & 0,822 \\
& Média & 0,076 & 0,013 & 0,206 & 0,059 & 37,475 & 4,720 \\
& Desvio Padrão & 0,084 & 0,016 & 0,103 & 0,041 & 28,026 & 6,121 \\
\hline
\end{tabular}

As concentrações encontradas foram compatíveis àquelas encontradas no afluente dos RAHLF, com predominância de Mn e Zn na drenagem ácida de minas utilizada.

A Figura 5.50 apresenta o comportamento do $\mathrm{pH}$ nas correntes afluente e efluente nesta etapa operacional.

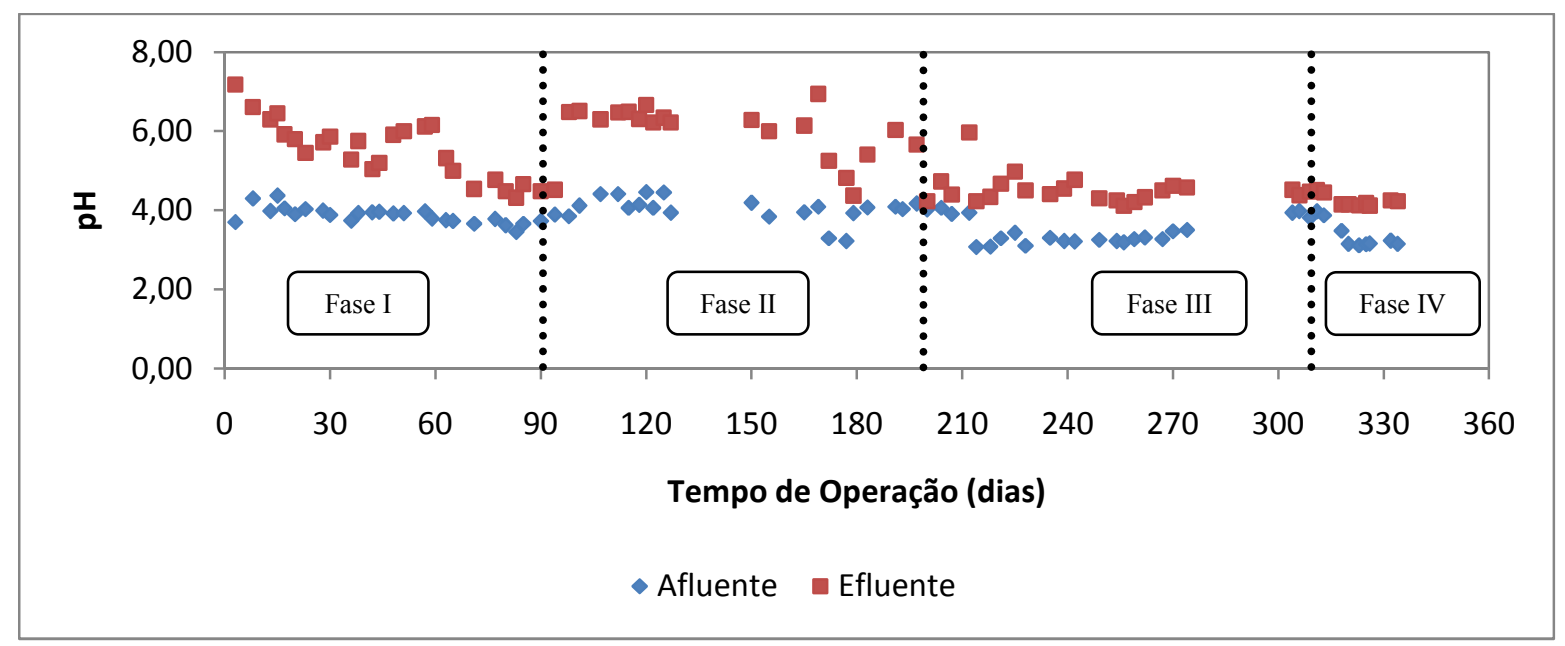

Figura 5.50. Variação do pH afluente e efluente no UASB, na etapa 2 de operação. 
$\mathrm{O}$ pH afluente apresentou pequena variação ao longo do período de operação do reator, com um valor médio de 3,9. É um $\mathrm{pH}$ superior ao que foi verificado nas etapas anteriores, resultado da diluição da drenagem ácida na preparação da alimentação. $\mathrm{O}$ pH da corrente efluente apresentou variação significativa na primeira fase. Após um período inicial de adaptação, observaram-se valores na corrente efluente de cerca de 6,0, mas verificou-se subsequente queda após o dia 60, estabilizando em um patamar de 4,54 antes da alteração na relação $\mathrm{DQO} / \mathrm{SO}_{4}{ }^{2-}$. $\mathrm{Na}$ segunda fase, após a alteração da quantidade de etanol na alimentação, o pH efluente apresentou comportamento estável, em um patamar superior ao alcançado na etapa anterior, de 5,80. Essa melhora no desempenho do reator em termos de elevação do pH é um indicativo de uma melhoria da redução do sulfato, pois a geração de alcalinidade é uma das consequências deste processo biológico.

$\mathrm{Na}$ fase III, como o reator passou a ser alimentado com drenagem bruta, nota-se queda no $\mathrm{pH}$ afluente e consequentemente queda no $\mathrm{pH}$ efluente. Mesmo com a diluição promovida pela corrente com água de abastecimento, não foi possível manter o $\mathrm{pH}$ afluente mais elevado, como conseguido nas fases I e II. Entretanto, os resultados de análises de DQO e sulfato mostraram que o reator manteve-se eficiente, mesmo com um $\mathrm{pH}$ de entrada menor. $\mathrm{O} \mathrm{pH}$ efluente mais ácido, provavelmente, foi resultado da maior carga de sulfato e íons $\mathrm{H}^{+}$residual efluente, pois mesmo com a manutenção da eficiência, a carga de sulfato efluente foi maior nessa fase em função da alimentação do reator com drenagem real.

O comportamento da DQO obtidos nas análises deste reator está apresentado na Figura 5.51. 


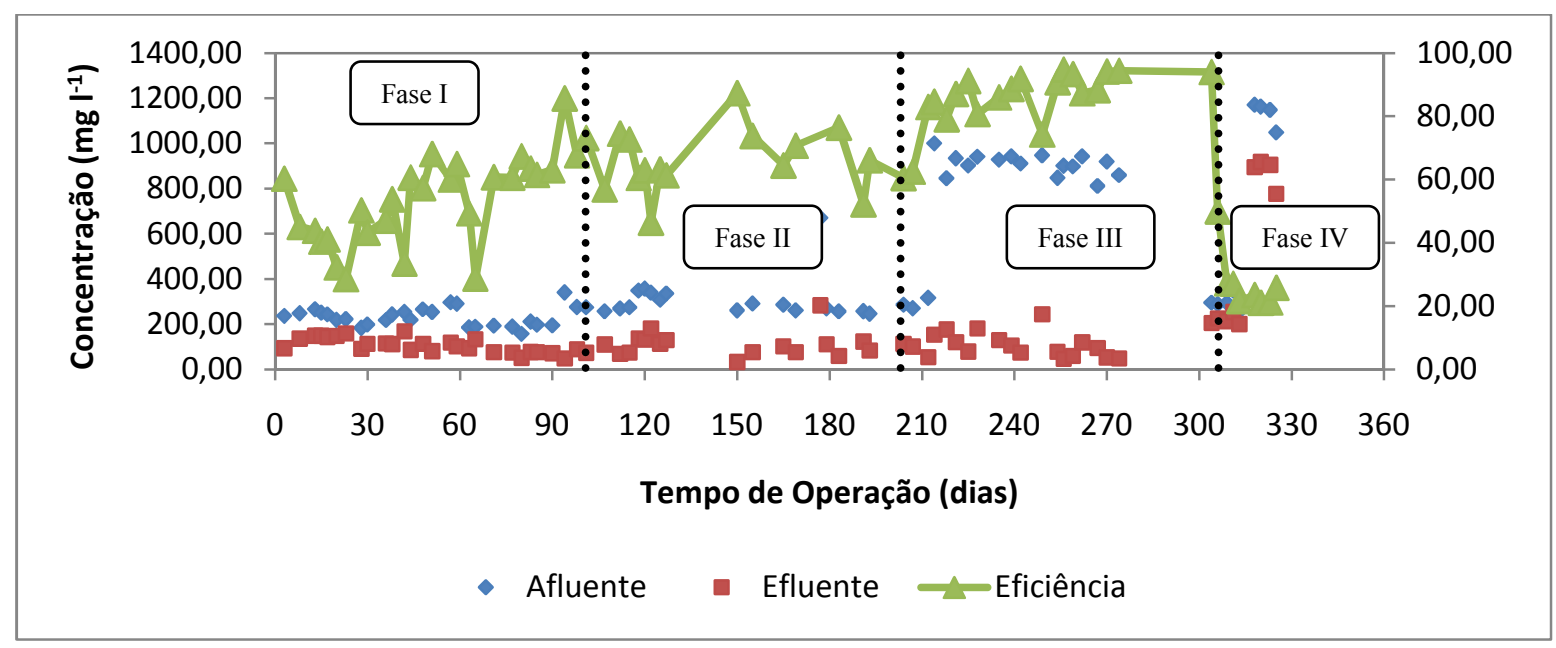

Figura 5.51. Variação da DQO afluente, efluente e da eficiência de remoção no UASB.

Após período inicial de certa instabilidade na remoção de DQO, o reator apresentou um comportamento estável, com uma média de $51,4 \% \pm 12,4 \%$ de eficiência de remoção de DQO durante a fase I. Este valor médio é substancialmente superior às médias verificadas nos três reatores da etapa $1,14,3 \%$ para U1, $18,7 \%$ para U2 e 33,3\% para o U3. O melhor desempenho do reator nesta condição operacional era esperado, visto que este está submetido a menores concentrações de sulfato e metais, além de um $\mathrm{pH}$ afluente ligeiramente maior. Ainda assim, a remoção de DQO na fase I ficou aquém do almejado, uma vez que, em um processo para a biorremediação de drenagem ácida, a presença de DQO residual é indesejada, pois implica em outros impactos ambientais.

Com o aumento da relação $\mathrm{DQO} / \mathrm{SO}_{4}{ }^{2-}$ para 1,0 na fase II, o reator apresentou melhora na remoção de DQO, com uma eficiência média $67,4 \% \pm 10,2 \%$. Esse resultado foi melhor do que aquele apresentado pelo reator $\mathrm{R} 3$ quando do aumento da relação $\mathrm{DQO} / \mathrm{SO}_{4}{ }^{2-}$. No reator R3, a remoção de DQO caiu de 75,7\% para 67,2 \% com o maior aporte de elétrons na fase II.

Os resultados observados com a DQO confirmaram o que já tinha sido observado nos reatores R2 e R3, de que o parâmetro mais determinante nas eficiências dos reatores 
estudados foi a carga de sulfato aplicada, que quando reduzida a valores de $0,35 \mathrm{~g} \mathrm{l}^{-1} \mathrm{dia}^{-1}$, proporcionou eficiências de remoção de DQO próximas ou até superiores a 70\%.

Com o início da fase III, a eficiência na remoção da DQO sofreu ligeira melhora, ficando em $85,5 \% \pm 15,0 \%$. No caso do reator UASB, a mudança no regime hidrodinâmico parece ter favorecido as reações de oxidação da matéria orgânica. O início da fase IV, agora recirculando o efluente tratado resultou em queda brusca na eficiência de remoção da DQO, exatamente como observado na recirculação do efluente tratado no reator R3.

Na comparação das fases III e IV, estima-se que a recirculação do efluente tratado devolve ao sistema substâncias tóxicas que poderiam se acumular durante a remoção de sulfato, entre elas, o sulfeto de hidrogênio.

Como reportado por vários autores na literatura (Tang et al., 2009; Kaksonen e Puhakka, 2007; Lens e Kuenen, 2001) a toxicidade dos íons sulfetos pode ser bastante acentuada sobre o metabolismo bacteriano. Considerando que nesses reatores estariam presentes consórcios de microrganismos altamente estruturados, é de se esperar que o aumento de um composto tóxico seja capaz de inviabilizar a continuidade da operação desses sistemas.

O monitoramento do reator quanto à presença de ácido acético no efluente está apresentado na Figura 5.52. 


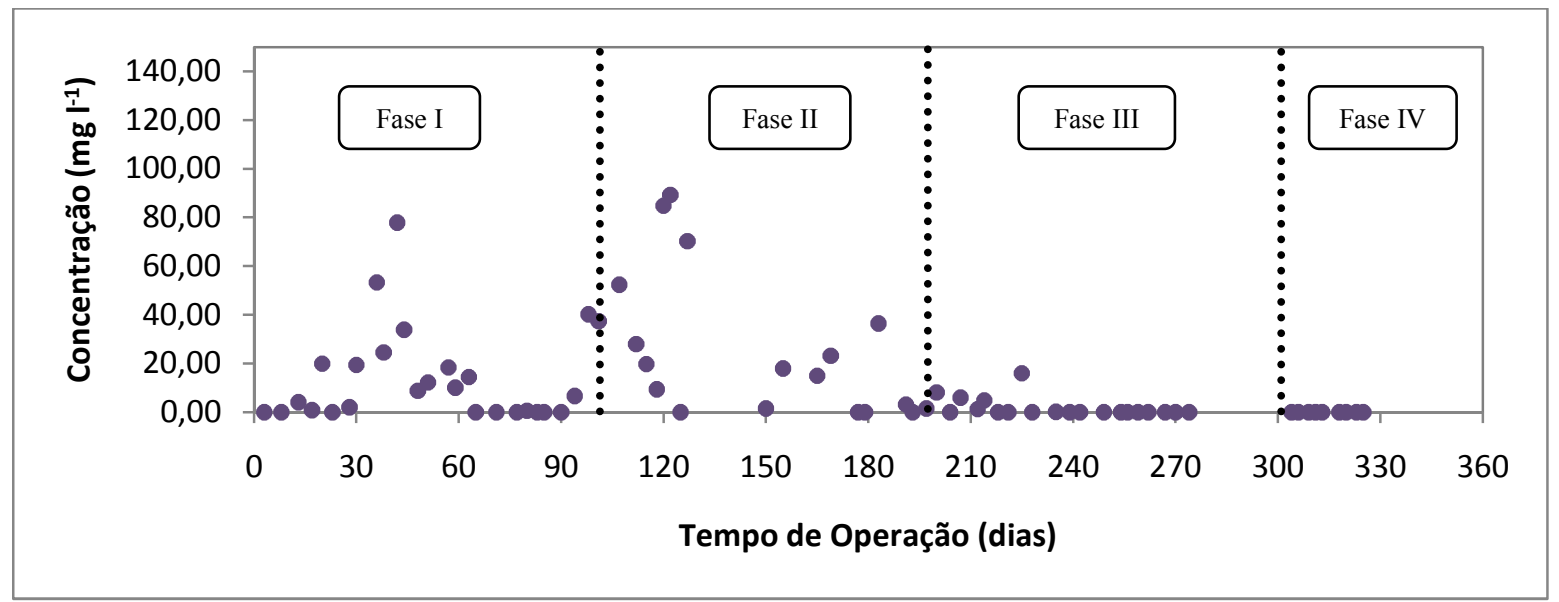

Figura 5.52. Concentrações de ácido acético (efluente - afluente) no UASB, na etapa B de operação.

A concentração de ácido acético analisado ao longo da operação do UASB esteve abaixo de $100 \mathrm{mg}^{-1}$, com valores inferiores na fase I e III. Durante a fase I, o valor médio de acetato encontrado foi de $12 \mathrm{mg}^{-1} \mathrm{dia}^{-1}$, um valor considerado baixo e que sinalizou que a oxidação do etanol ocorreu completamente. Com o aumento do aporte de elétrons na fase II, o valor médio de acúmulo de acetato foi de $24,8 \mathrm{mg} \mathrm{l}^{-1} \mathrm{dia}^{-1}$, maior do que a fase anterior e que indicou que o excesso de matéria orgânica pode ter dificultado a oxidação completa por redutoras de sulfato completas, resultando em acúmulo de acetato. Com o início das fases III e $\mathrm{IV}$, as concentrações de ácido acético foram muito reduzidas, com média de $1,8 \mathrm{mg} \mathrm{l}^{-1} \mathrm{dia}^{-1}$. Durante a fase III, a oxidação da matéria orgânica ocorreu de maneira completa, mesmo utilizando-se um excesso de elétrons. $\mathrm{Na}$ fase IV, com o desequilíbrio do reator, não foi detectada alteração na concentração de acetato efluente.

As análises de sulfato e a eficiência de remoção estão mostradas na Figura 5.53. 


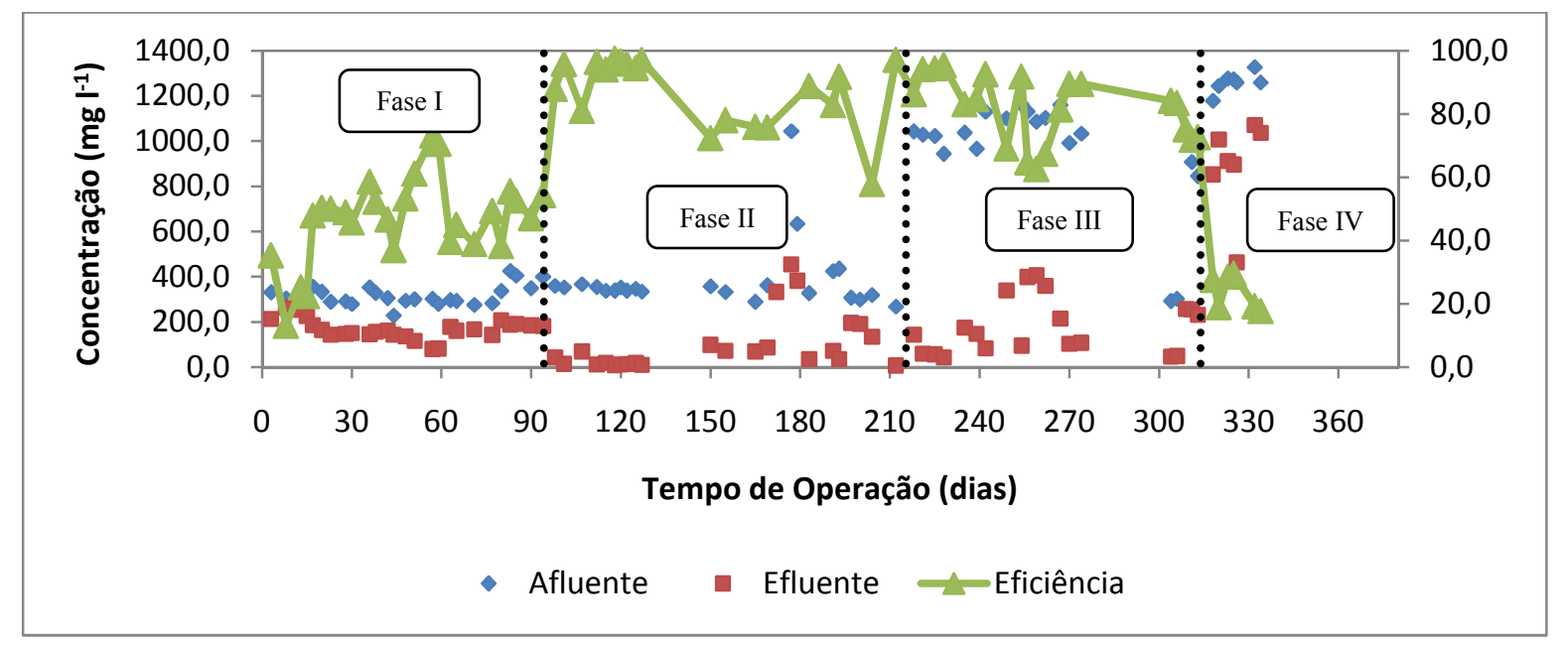

Figura 5.53. Variação da concentração de sulfato afluente, efluente e da eficiência de remoção no UASB, na segunda etapa de operação.

Durante a fase I de operação do UASB, a remoção de sulfato foi baixa considerando os resultados obtidos com o reator R3. Nessa fase, o reator UASB apresentou uma remoção média de sulfato de $46,3 \% \pm 13,8 \%$, bem abaixo dos $72,8 \%$ conseguido com o reator R3. No reator UASB, a relação estequiométrica $\mathrm{DQO} / \mathrm{SO}_{4}{ }^{2-}$ não parece ter favorecido de maneira satisfatória a biomassa redutora de sulfato, possivelmente, porque nesse sistema podem ter se estabelecido em sua maioria, as BRS oxidadoras incompletas e, nesse caso, o etanol na relação de 0,67 seria insuficiente para favorecer uma alta remoção de sulfato.

Com o aumento da relação $\mathrm{DQO} / \mathrm{SO}_{4}{ }^{2-}$ para 1,0 , rapidamente houve aumento da remoção de sulfato, com eficiência média nesta fase de $85,6 \% \pm 13,1 \%$. Esse foi o melhor resultado em termos de remoção de sulfato apresentado entre todos os reatores estudados. $\mathrm{Na}$ fase II, o reator parece ter encontrado as melhores condições para o seu funcionamento no que diz respeito a redução do íon sulfato. A redução de sulfato aumentou em conjunto com o aumento de elétrons disponíveis. A necessidade de matéria orgânica em quantidade acima da relação $\mathrm{DQO} / \mathrm{SO}_{4}{ }^{2-}$ de 0,67 ocorre, pois essa é uma relação teórica, que assume que o todo o processo é conduzido por BRS que oxidam completamente o etanol. Contudo, essa consideração é demasiadamente simplificada, pois acaba por ignorar outros processos (tais 
como fermentação e oxidação incompleta) que podem ocorrer concomitantemente e que resultariam numa redução dos elétrons disponíveis para a redução do sulfato (Damianovic e Foresti, 2007). Vale ressaltar, entretanto, que o reator UASB continha uma quantidade de biomassa três vezes maior (35,0 $\mathrm{g} \mathrm{STV}^{-1}$ de volume útil) do que o reator R3 no início da operação.

Com o início da fase III, o sistema pouco se alterou quanto a eficiência na remoção de sulfato, permanecendo em $82,3 \% \pm 17,4 \%$. Diferentemente da recirculação com o efluente tratado testada no reator $\mathrm{R} 3$, a simulação de uma corrente de recirculação com água de abastecimento no reator UASB não comprometeu o funcionamento do reator, tanto com relação a remoção de DQO quanto de sulfato.

Com a finalidade de investigar a questão a influência do escoamento hidrodinâmico e da toxicidade, foi implantado um sistema de recirculação com o efluente tratado, em uma razão de recirculação que mantivesse a mesma concentração de sulfato afluente adotada até então. O que se observou na fase IV, todavia, é que assim que a recirculação com água foi substituída, o sistema entra em declínio quanto a remoção de sulfato, com eficiências de remoção inferiores a $50 \%$. Esse mesmo comportamento foi o observado no reator R3, que entrou em colapso após a inserção de recirculação do efluente tratado.

Aparentemente, o reator UASB sofreu menos impacto com a mudança no regime de escoamento provocada pela recirculação, porém quando o efluente contendo intermediários tóxicos, como o sulfeto, retornou ao início do reator, este sofreu os mesmos efeitos observados no RAHLF 3.

A geração de sulfeto durante a operação do reator UASB na etapa B pode ser verificado na Figura 5.54. 


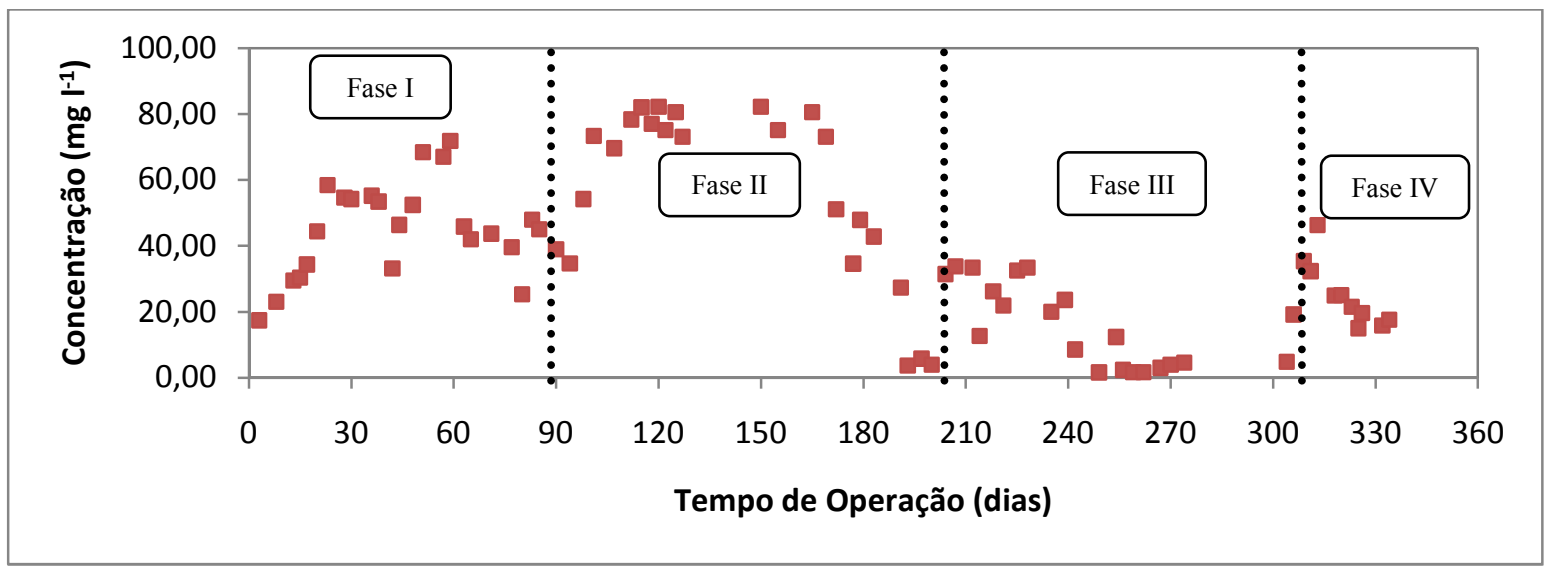

Figura 5.54. Variação da concentração de sulfeto afluente e efluente no UASB, na etapa 2 de operação.

As análises de sulfeto obtidas durante a operação desse reator foram bastante instáveis, como notado para os reatores RAHLF. Normalmente, os resultados estiveram abaixo do esperado pela relação estequiométrica entre o sulfato reduzido e o sulfeto gerado. Os mesmos fatores citados anteriormente, como dificuldade de se aferir o sulfeto na forma de $\mathrm{H}_{2} \mathrm{~S}$, a precipitação com sulfetos metálicos ou ainda, a oxidação parcial a enxofre elementar $\left(\mathrm{S}^{0}\right)$, poderiam explicar essas diferenças.

É interessante notar, entretanto, que com o início da fase III, os resultados para a análise de sulfeto sofreram uma queda acentuada. Considerando que com o início dessa fase, o pH efluente sofreu uma ligeira queda, poderia ser esperado que o equilíbrio das frações de sulfeto estaria mais deslocado para a produção do gás sulfídrico e isso dificultaria a determinação desse composto durante esse período.

A Tabela 5.11 mostra de forma comparativa os resultados obtidos com a operações dos reatores $\mathrm{R} 1, \mathrm{R} 2$ e $\mathrm{R} 3$ com relação ao $\mathrm{pH}$ efluente, a remoção de $\mathrm{DQO}$ e sulfato e a geração de ácido acético e sulfeto. 
Tabela 5.11. Resultados das análises de monitoramento para o reator UASB na etapa B.

\begin{tabular}{cccccc}
\hline Fase & $\begin{array}{c}\mathbf{p H} \\
\text { Efluente }\end{array}$ & $\begin{array}{c}\text { Remoção de } \\
\text { DQO (\%) }\end{array}$ & $\begin{array}{c}\text { Ácido acético } \\
\left.\mathbf{( m g ~ l}^{\mathbf{- 1}}\right)\end{array}$ & $\begin{array}{c}\text { Remoção de } \\
\mathbf{S O}_{\mathbf{4}}^{\mathbf{2}} \mathbf{( \% )}\end{array}$ & $\begin{array}{c}\text { Sulfeto } \\
\left(\mathbf{m g ~ l}^{\mathbf{1}} \mathbf{)}\right.\end{array}$ \\
\hline I & 4,3 & 51,4 & 12,0 & 46,3 & 44,9 \\
II & 4,1 & 67,4 & 25,0 & 85,6 & 56,9 \\
III & 7,0 & 85,5 & 1,8 & 82,3 & 18,6 \\
IV & 5,8 & 23,0 & 2,0 & 24,0 & 19,9 \\
\hline
\end{tabular}

O reator UASB quando operado com carga de sulfato aplicada reduzida (etapa B) também apresentou melhora significativa nos resultados de eficiência de remoção de DQO e sulfato. Porém, diferentemente do reator R3, o aumento do aporte de elétrons da fase I para a fase II influenciou-se positivamente o processo, com aumento nos valores de eficiência de remoção de sulfato e matéria orgânica. Na verdade, para o UASB, o aumento da $\mathrm{DQO} / \mathrm{SO}_{4}{ }^{2-}$ de 0,67 para 1,0 resultou em um aumento de $30 \%$ na remoção de DQO e de $85 \%$ na remoção de sulfato. A simulação do sistema de recirculação na fase III promoveu significativa melhora na remoção de DQO, porém teve pouca influência sobre a remoção de sulfato.

Com relação ao pH efluente, na fase III, quando o reator obteve o melhor desempenho quanto as eficiências de remoção, o pH efluente ficou muito mais elevado do que nas outras fases analisadas. Em nenhuma das fases analisadas notou-se acúmulo de ácido acético e o sulfeto analisado pode ser utilizado como um indicativo da sulfetogênese.

No caso do UASB, a carga de sulfato aplicada também foi o principal fator de influência sobre a melhora no processo de remoção de sulfato. Entretanto, esse reator apresentou resultados ainda mais promissores do que os obtidos com o reator R3. 


\subsubsection{Perfis espaciais do reator UASB na etapa B (fases II e IV)}

Ao final da fase experimental II, no $127^{\circ}$ dia de operação foi realizado um perfil espacial para acompanhamento das variáveis $\mathrm{pH}$, sulfato, sulfeto, DQO, etanol e ácido acético ao longo do reator anaeróbio. Os pontos de amostragem em L/D de 0 e 12 representam o afluente e o efluente do reator, respectivamente. Os demais pontos se referem às três válvulas de amostragem presentes no corpo do reator. Nesta etapa de operação a manta de lodo alcançava o ponto de amostragem 4 (L/D de 7).

O comportamento do $\mathrm{pH}$ ao longo do reator, apresentado na Figura 5.55, mostrou que a partir do $3^{\circ}$ ponto de amostragem, o reator tinha atingido o máximo de remoção de acidez do meio líquido, com um pH final de 6,0, com pequena variação nos pontos de amostragem subsequentes.

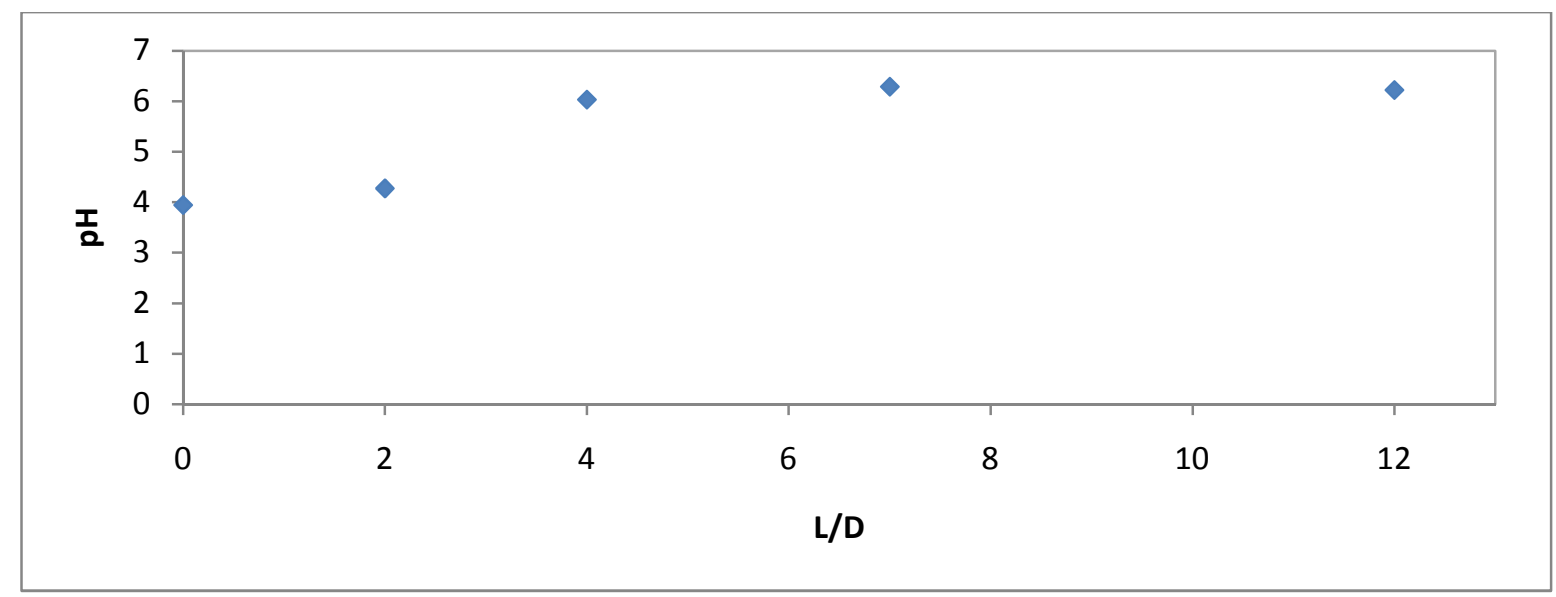

Figura 5.55. Variação do pH ao longo do reator UASB (etapa B - fase II).

A Figura 5.56 apresenta a variação na concentração de DQO, sulfato e sulfeto ao longo do reator ao final da fase II de operação. 


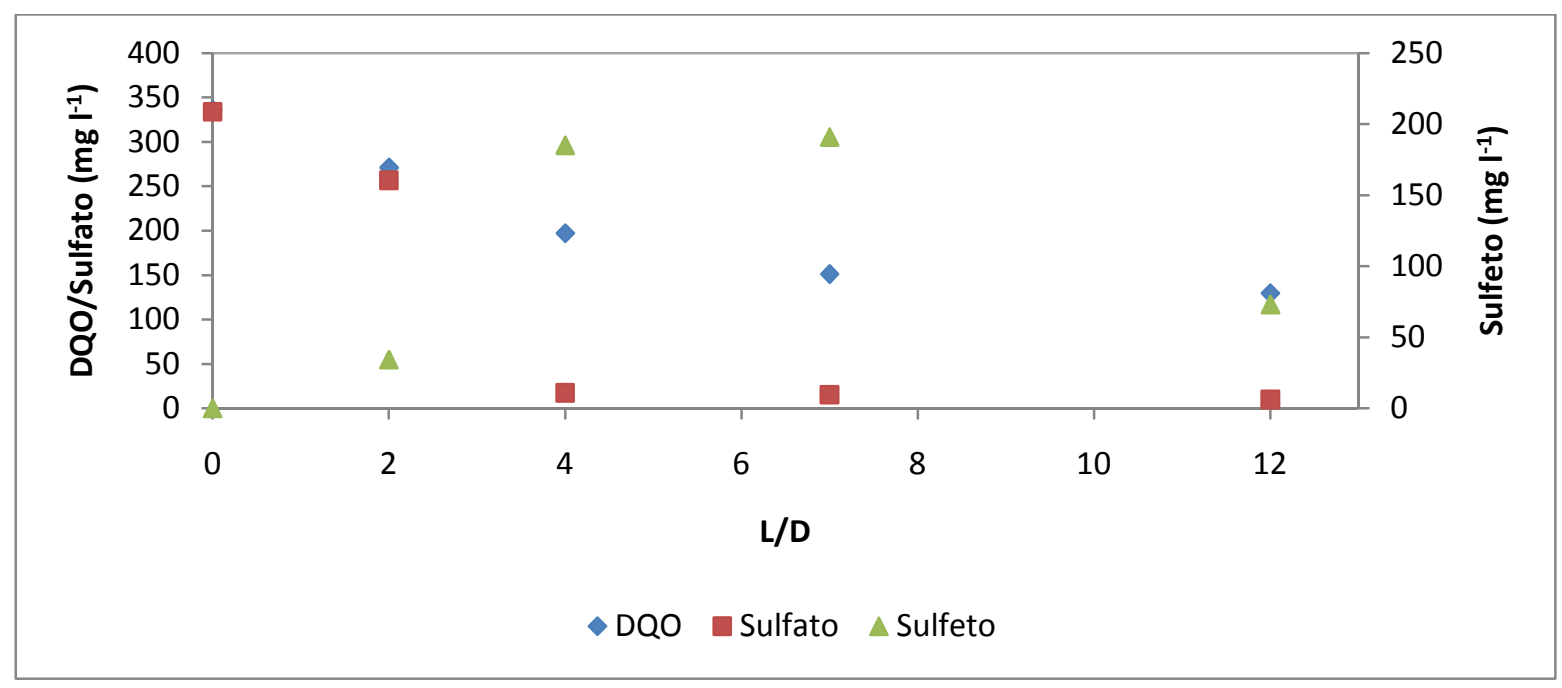

Figura 5.56. Variação da DQO, sulfato e sulfeto ao longo do reator UASB (etapa B - fase II).

É observado contínuo consumo de matéria orgânica nos quatro primeiros pontos de amostragem, indicando boa distribuição da atividade microbiana ao longo do reator, entretanto a oxidação se deu de maneira mais expressiva até $\mathrm{L} / \mathrm{D}$ de 4 , o que poderia indicar que a porção da manta de lodo presente até este ponto estaria mais apta a utilizar o etanol. Para o sulfato, mais do que para a DQO, tem-se um consumo quase que total até o $3^{\circ}$ ponto do reator, não sendo mais detectada concentração considerável deste receptor de elétron a partir deste ponto. Aparentemente, a atividade sulfetogênica deste reator estaria concentrada na fração inicial deste reator, visto que a produção de sulfeto acompanha o que seria esperado segundo a redução do sulfato, ocorrendo entre o afluente e L/D de 4, sendo substancialmente superior entre L/D de 2 e 4. Esse comportamento indica que o reator UASB não funcionava como um reator de mistura, como indicado no estudo hidrodinâmico para um volume de manta de lodo três vezes menor do que o empregado nessa etapa, e sim como um reator de fluxo mais próximo do tubular quando se operou o reator com $468 \mathrm{ml}$ de volume de lodo granular.

Observou-se queda na concentração de sulfeto no último ponto de amostragem, provavelmente devido à perda por volatilização ou oxidação até outros compostos por 
moléculas de oxigênio que poderiam permear as mangueiras de silicone acopladas à saída do reator. Nesta segunda etapa experimental também foi verificada a formação de substâncias branco-amareladas na proximidade da interface líquido-gás, possivelmente enxofre elementar. Desta vez a formação não se limitou às superfícies internas do reator, ocorrendo na superfície do nível d’água, em películas que, após aumentarem de tamanho e densidade, sedimentavam até o topo da manta de lodo, como pode ser observado na Figura 5.57.

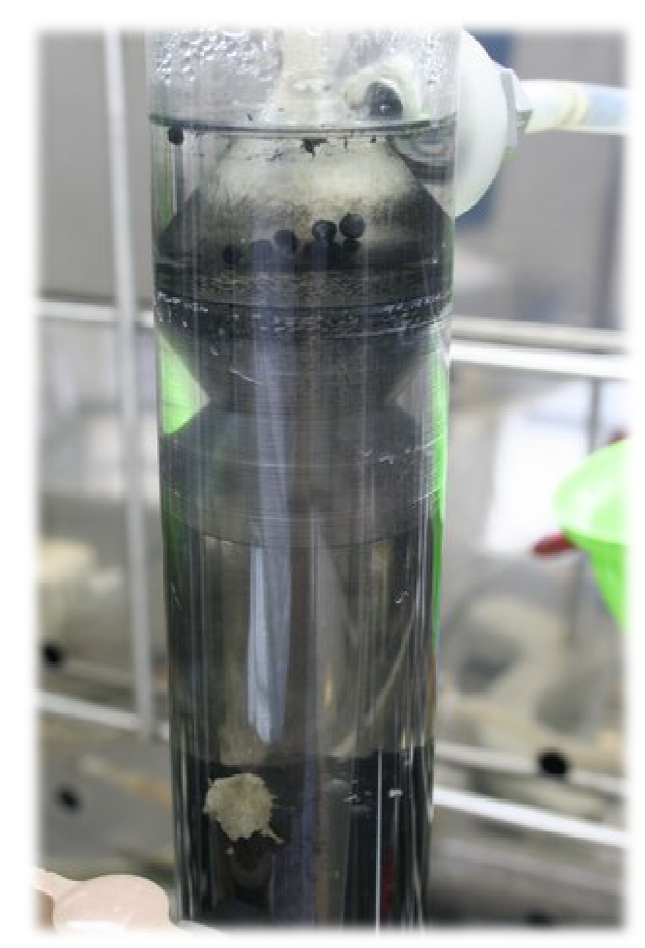

Figura 5.57. Formação de película amarelada no interior do reator UASB, durante a segunda fase de operação.

O perfil espacial mostrou que a redução biológica de sulfato permaneceu localizada em frações do reator, sendo mais expressiva entre L/D de 2 e 4 . Indica-se também a ocorrência de outros processos que consomem matéria orgânica sem utilizar o sulfato como receptor final de elétrons, visto o consumo substancial de DQO entre L/D de 4 e 7 , sem variação significativa da concentração de sulfato e sulfeto. 
As concentrações de etanol e ácido acético também foram determinadas ao longo do reator e estão apresentadas na Figura 5.58.

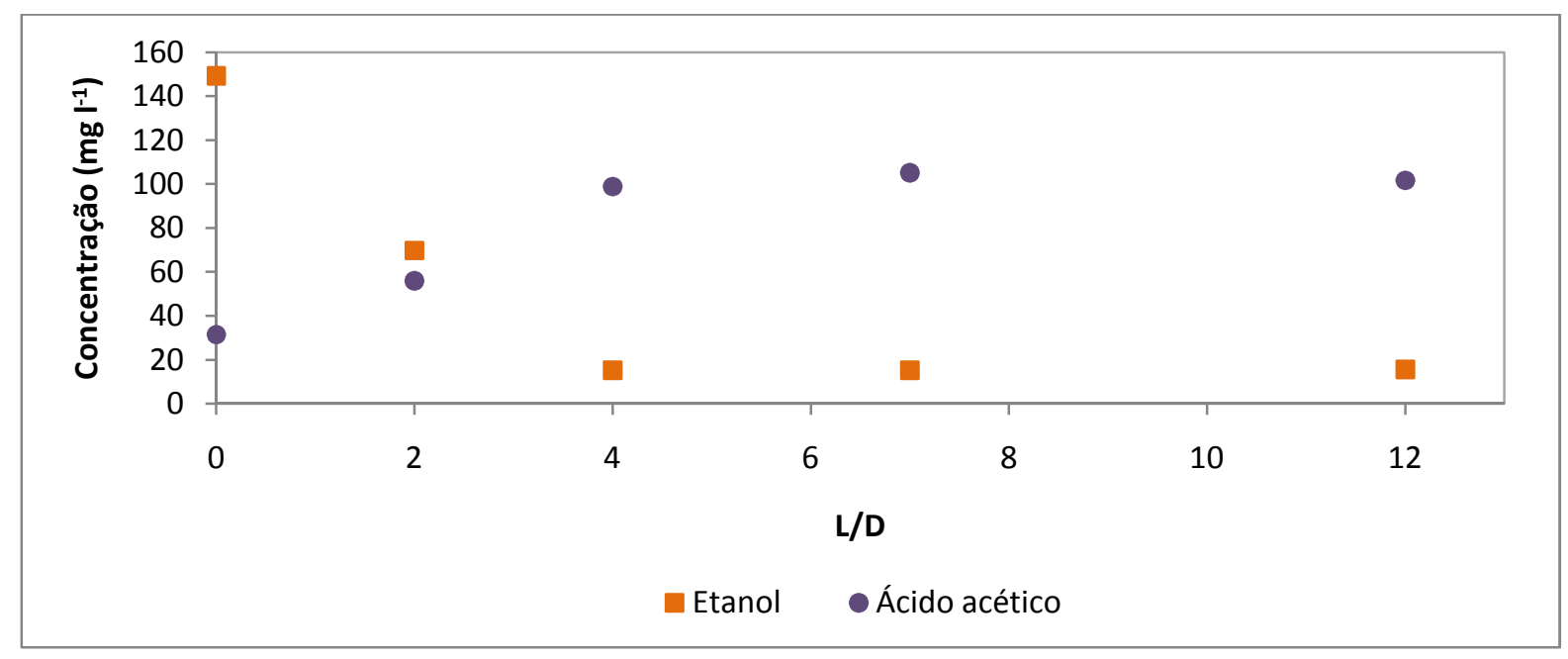

Figura 5.58. Variação na concentração de etanol e ácido acético ao longo do reator UASB (etapa B - fase II).

Da mesma maneira que o $\mathrm{pH}$, a DQO e o sulfato, percebe-se que o consumo de etanol ocorre até o $3^{\circ}$ ponto do reator, sendo que neste ponto a concentração de ácido acético atingiu, praticamente, seu valor máximo. Esse comportamento confirmou que a atividade microbiana de redução de sulfato estava localizada até o $3^{\circ}$ ponto do reator, não sendo observadas modificações importantes a partir deste ponto. Não foi detectado consumo de ácido acético na porção final do reator, como ocorreu com os reatores RAHLF, o que parece indicar que no reator UASB, na fase II, conseguiu-se estabelecer um reator estritamente sulfetogênico.

Ao término da operação do reator UASB no $348^{\circ}$ dia, na fase $\mathrm{IV}$, foi realizado um perfil espacial com acompanhamento dos mesmos parâmetros do perfil da fase II. Os pontos de L/D de 0 e 12 representam o afluente e o efluente do reator, respectivamente. Os demais pontos se referem às três válvulas de amostragem presentes no corpo do reator. Nesta etapa de operação, o reator estava funcionando com recirculação do efluente tratado e como discutido 
nas análises de monitoramento, a mudança de água para efluente tratado na recirculação ocasionou instabilidade no funcionamento do reator.

A Figura 5.59 mostra que o $\mathrm{pH}$ sofreu ligeira variação ao longo do comprimento do reator, com um aumento mais significativo entre o afluente e o $1^{\circ}$ pontos de amostragem (ponto 2), mantendo-se estável durante as coletas subsequentes.

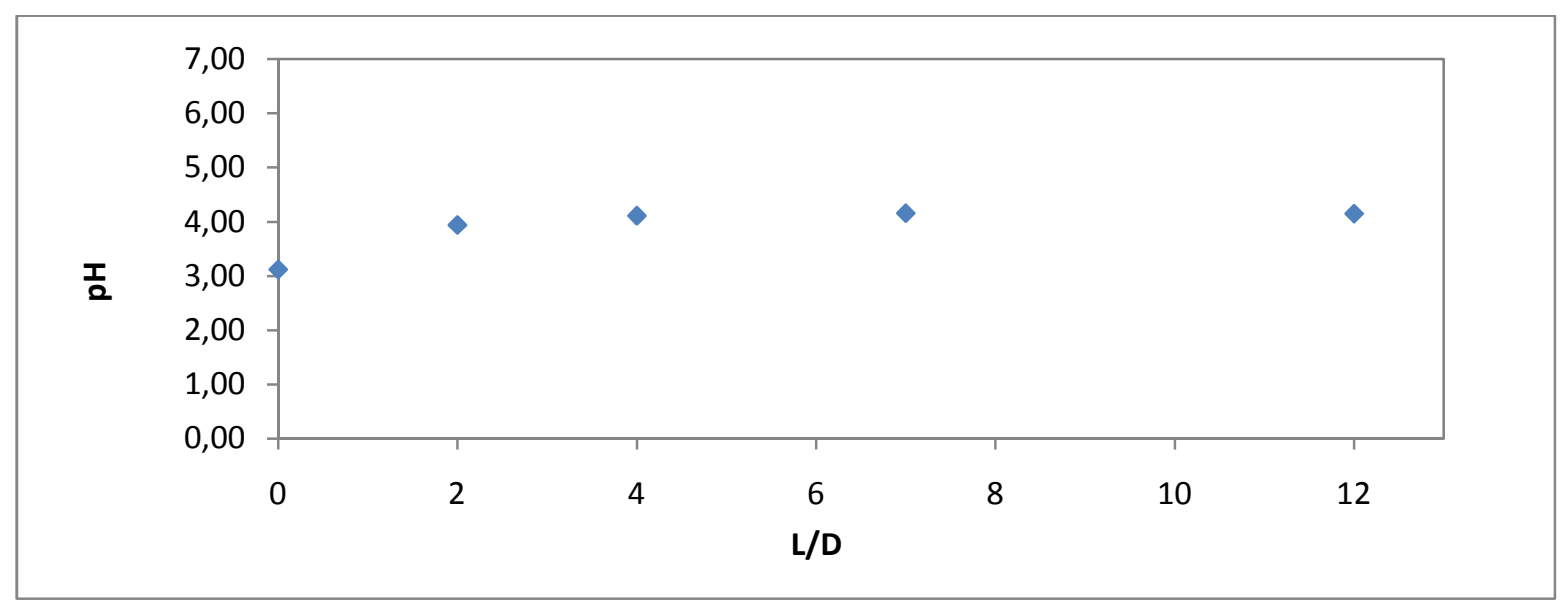

Figura 5.59. Variação do pH ao longo do reator UASB (etapa B - fase IV).

Com relação ao comportamento da DQO, do sulfato e do sulfeto, nota-se através da Figura 5.60 que os mesmos sofreram variações pequenas, que refletiram a queda na eficiência ocorrida nessa fase do reator. 


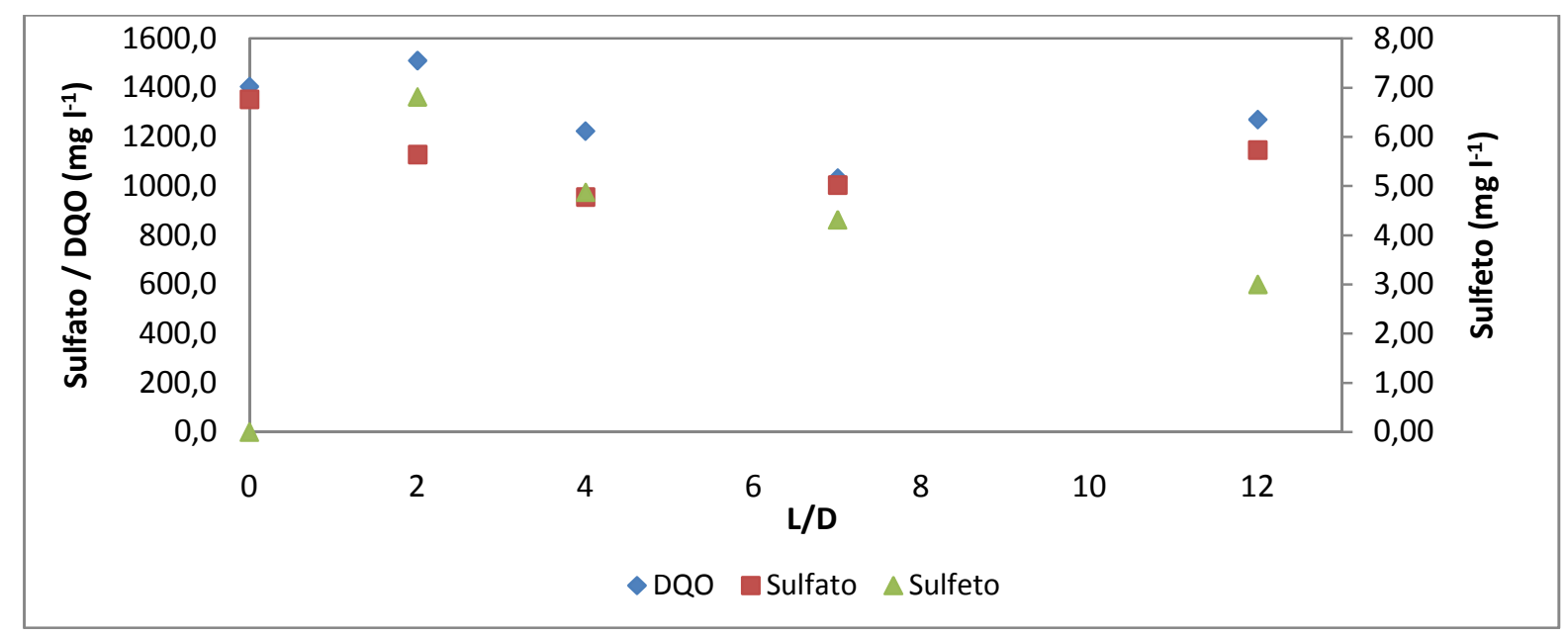

Figura 5.60. Variação da DQO, sulfato e sulfeto ao longo do reator UASB (etapa B - fase IV).

A DQO, após sofrer ligeiro aumento em L/D de 2, foi removida até L/D de 7, sendo observado aumento entre o $4^{\circ}$ e $5^{\circ}$ ponto. A maior eficiência de remoção da DQO deu-se em L/D de 7 com 26,5\% de redução da DQO afluente. Entretanto, esse valor foi muito abaixo da eficiência obtida nas fases anteriores do reator (II e III), com destaque para a Fase III, com mesmo após a inserção de recirculação com água de abastecimento, o reator manteve a remoção de DQO em 85,5\%. A recirculação com efluente tratado na Fase IV não alcançou o objetivo proposto que seria oferecer uma resposta a utilização de água tratada para a diluição do afluente. O mesmo ocorreu com o reator RAHLF 3 que entrou em colapso após a inserção de recirculação do efluente tratado.

Com relação ao sulfato, o reator apresentou remoção do mesmo até L/D de 4, com 29,4\% de redução, sendo que após esse ponto notou-se aumento do sulfato nos últimos dois pontos, provavelmente, como resultado de processos de oxidação do sulfeto gerado no reator. As baixas concentrações de sulfeto detectadas nesse reator impediram a confirmação desse fenômeno, visto que não se percebeu queda no sulfeto produzido entre os dois últimos pontos. 
Como na fase IV, o reator já vinha apresentando resultados insatisfatórios, o perfil foi realizado apenas para que se pudesse detectar algum comportamento distinto ao longo do reator.

Com o desligamento do reator UASB após 350 dias operação, percebeu-se como o leito estava estratificado ao longo do comprimento do reator, apresentando diferenças visíveis de coloração e estruturas dos grânulos. A Figura 5.61 mostra o leito visualmente estratificado ainda dentro do reator.

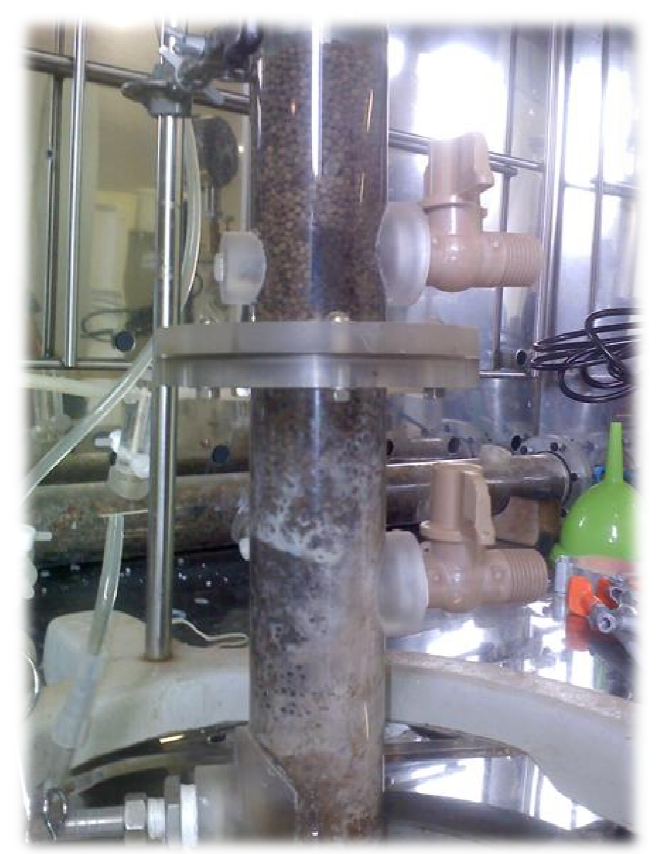

Figura 5.61. Estratificação do leito do reator UASB (etapa B).

Percebe-se que no início do reator, o leito estava esbranquiçado, com presença de polímeros entre os grânulos e os grânulos apresentavam uma coloração mais opaca, enquanto na porção mais acima, o leito encontrava-se intacto, com grânulos bem estruturados e de coloração próxima a quando foram inoculados. 
As Figuras 5.62 (a) e 5.62 (b) mostram a características dos grânulos após a desmontagem do reator. Na Figura 5.62 (a), os grânulos da porção inicial do reator mostram uma aparência distinta do que os grânulos da Figura 5.62 (b) que se mostram mais estruturados e sem a presença de polímero.

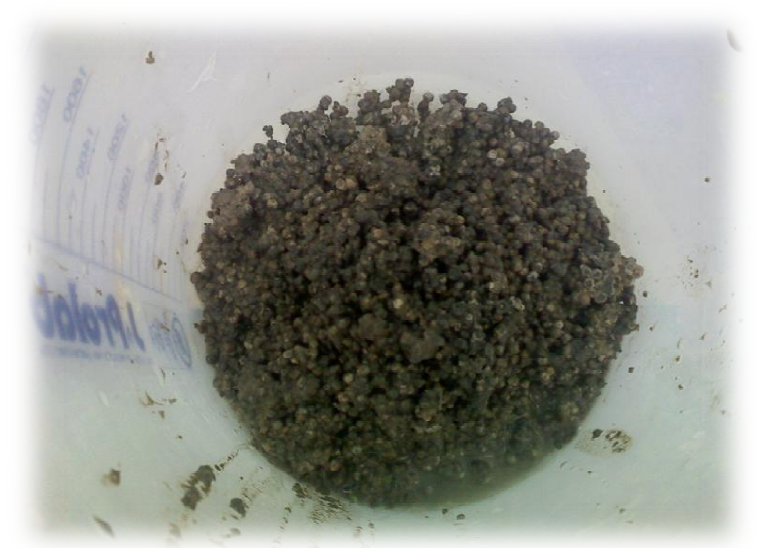

(a)

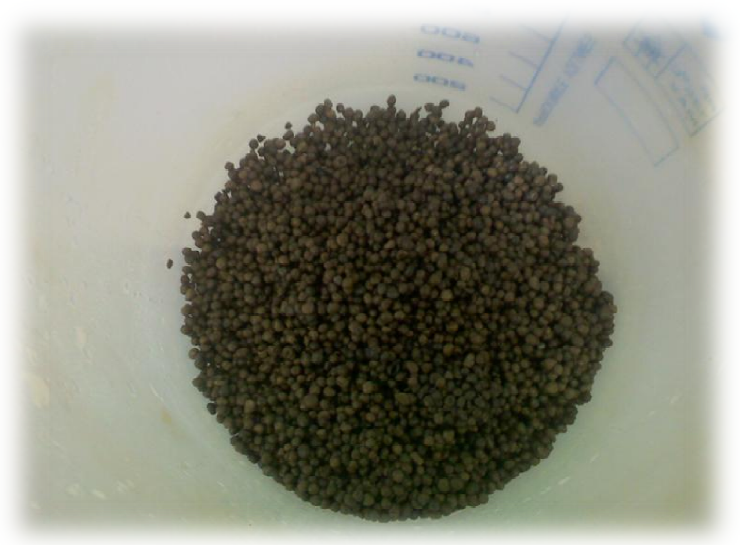

(b)

Figura 5.62. Grânulos do leito do reator UASB (etapa B): a) porção inicial do reator; b) porção final.

\subsubsection{Balanço de massa do reator UASB (etapa B)}

Assim como para os reatores RAHLF, tentou-se estimar, para o reator UASB da etapa 2, os principais caminhos metabólicos microrganismos redutores de sulfato e a presença de outras vias de utilização da DQO que não a redução do sulfato (Tabela 5.12). Na análise do reator não foram considerados os períodos de partida do reator e a fase IV na qual o reator se instabilizou após a inserção de recirculação do efluente tratado. 
Tabela 5.12. Dados de eficiência de remoção de DQO e sulfato e acúmulo de ácido acético na etapa B de operação do reator UASB.

\begin{tabular}{|c|c|c|c|c|}
\hline Fase & $\begin{array}{c}\text { Carga DQO } \\
\text { removida } \\
\left(\mathrm{mg} \mathrm{l}^{-1} \text { dia }^{-1}\right)\end{array}$ & $\begin{array}{c}\text { Carga etanol } \\
\text { removida } \\
\left(\mathrm{mg} \mathrm{l}^{-1} \text { dia }^{-1}\right)\end{array}$ & $\begin{array}{c}\mathrm{Carga}_{\mathrm{SO}_{4}}{ }^{2-} \\
\text { removida } \\
\left(\mathrm{mg} \mathrm{l}^{-1} \text { dia }^{-1}\right)\end{array}$ & $\begin{array}{c}\text { Ácido acético } \\
\text { [Ef -Af] } \\
\left(\mathrm{mg} \mathrm{l}^{-1}\right)\end{array}$ \\
\hline I & 117,0 & 56,0 & 146,0 & 12,0 \\
\hline II & 203,0 & 97,0 & 303,0 & 25,0 \\
\hline III & 800,0 & 383,0 & 880,0 & 2,0 \\
\hline
\end{tabular}

A carga de DQO removida na fase I de operação do reator UASB se oxidada completamente a $\mathrm{CO}_{2}$ e $\mathrm{H}_{2} \mathrm{O}$ iria promover a redução de $175 \mathrm{mg} \mathrm{SO}_{4}{ }^{2-} 1^{-1}$ dia $^{-1}$. Sabe-se que a concentração média de ácido acético gerada no sistema foi de $12,0 \mathrm{mg}^{-1}$. Caso todo o acetato tenha sido originado da via oxidativa incompleta, seriam necessários 9,3 $\mathrm{mg}$ etanol $\mathrm{l}^{-1}$, o que corresponde a $19,4 \mathrm{mg}$ DQO ${ }^{-1}$. Pela via incompleta, portanto, seria reduzidos $10,0 \mathrm{mg} \mathrm{SO}_{4}{ }^{2-}$ $\mathrm{l}^{-1} \mathrm{dia}^{-1}$.Sendo a carga removida de DQO de $117 \mathrm{mg} \mathrm{l}^{-1}$, restariam ainda $97 \mathrm{mg}$ DQO $\mathrm{l}^{-1}$. Essa quantidade de DQO poderia reduzir pela via completa $144 \mathrm{mg} \mathrm{SO}_{4}{ }^{2-} \mathrm{l}^{-1} \mathrm{dia}^{-1}$. Somando-se a quantidade de sulfato removida em cada via (completa + incompleta), chega-se em $154 \mathrm{mg}$ $\mathrm{SO}_{4}{ }^{2-} 1^{-1} \mathrm{dia}^{-1}$, valor ligeiramente acima da carga de sulfato removida no sistema. Nota-se que na fase I de operação do reator UASB, o consumo de doador de elétrons ocorreu, provavelmente, apenas por bactérias redutoras de sulfato.

Durante a fase II, o acúmulo de acetato foi ligeiramente superior ao da fase I. Considerando, inicialmente, que as bactérias redutoras de sulfato tenham oxidado completamente o etanol, a carga removida de etanol de $97 \mathrm{mg}^{-1}$ dia $^{-1}$ seria suficiente para reduzir $304 \mathrm{mg} \mathrm{SO}_{4}{ }^{2-} 1^{-1}$ dia $^{-1}$. Isso significa que a via com maior rendimento de redução de sulfato resultaria em um valor idêntico àquele observado na fase II do reator. Entretanto, foi detectado acúmulo de acetato na saída do reator, o que significa que parte do etanol pode ter sido oxidada pela via incompleta ou, ainda, que outras fontes de matéria orgânica estivessem sendo utilizadas para oxidação. Como não era adicionada nenhuma fonte orgânica diferente do etanol, essa hipótese poderia ser atribuída à endogenia do sistema ou utilização de 
polímeros acumulados no reator. Considerando o baixo valor de acetato detectado, ficou complicado estabelecer se existia uma via principal.

$\mathrm{Na}$ fase III, foram obtidas remoções maiores de DQO e sulfato, visto que o reator passou a ser alimentado com drenagem bruta. Sabendo-se que não havia acetato a corrente efluente, foi realizado o balanço de massa para a oxidação completa do etanol. Dessa forma, a carga de sulfato removida deveria ser de $1200 \mathrm{mg} \mathrm{SO}_{4}{ }^{2-} 1^{-1} \mathrm{dia}^{-1}$, porém o que foi detectado neste reator foi uma redução $24 \%$ menor do que o valor teórico. Como na fase II, o balanço de massa foi quase fechado, é interessante notar que com a diluição agora promovida por uma corrente de água acoplada a entrada do reator (fase III), ocorreu um desvio na utilização da matéria orgânica para outras vias que não a redução do sulfato. A mudança provocada pela alteração no escoamento hidrodinâmico parece ter favorecido o desenvolvimento de comunidades microbianas que não utilizavam o sulfato como receptor de elétrons ou, ainda, estimularam a utilização de outros receptores de elétrons.

Com discutido para os RAHLF, é provável que, em função da presença de metais, outros compostos funcionassem como receptores de elétrons. Segundo Lovley (2006), uma grande variedade filogenética de microrganismos tanto bactérias quanto arqueias são capazes de realizar a redução dissimilativa do $\mathrm{Fe}(\mathrm{II})$ e do $\mathrm{Mn}(\mathrm{IV})$. Os mesmos autores relatam que a bactérias redutoras de sulfato podem utilizar o Fe(III), Mn (IV) e U(VI) como receptores de elétrons. No caso do Fe(III), foi demonstrado que se esse foi o único receptor de elétrons disponível, as BRS não o utilizam, porém na presença de sulfato, foi observada a redução do $\mathrm{Fe}(\mathrm{III})$. A redução do $\mathrm{Fe}(\mathrm{III})$ nas BRS parece ocorrer no citocrome $c 3$, que atua como uma ferro redutase e poderia, em determinadas situações, utilizar o $\mathrm{Fe}(\mathrm{III})$ presente. É possível ainda que, de acordo com os mesmos autores, a redução do Fe(III) seja uma estratégia das BRS para promover uma diminuição na quantidade de Fe(III) e favorecer as condições para a redução do sulfato, que em termos energéticos é muitas vezes mais favorável. 


\section{CAPÍTULO 6}

\section{CONCLUSÕES}

As conclusões do presente trabalho são apresentadas a seguir.

Ensaios de aderência microbiana em reatores diferenciais

- A fonte de carbono influenciou a aderência e a quantidade de microrganismos presentes na espuma de poliuretano, estando a concentração de sólidos totais voláteis inversamente relacionada com a quantidade de carbonos de cada substrato utilizado;

- O tipo de inóculo foi mais importante na variação da concentração de STV quando etanol foi utilizado como fonte de carbono $\left(0,30 \mathrm{~g} \mathrm{STV}^{-1}\right.$ espuma para lodo de abatedouro e $0,16 \mathrm{~g}$ $\mathrm{STV} \mathrm{g}^{-1}$ espuma para sedimento de mina);

- As velocidades máximas de colonização foram maiores para as três fontes de carbono quando se utilizou inóculo de abatedouro de aves $\left(0,022 \mathrm{~g} \mathrm{SVT} \mathrm{g}^{-1}\right.$ espuma dia ${ }^{-1}$ para ácido fórmico e 0,024 $\mathrm{g} \mathrm{SVT}^{-1}$ espuma dia $^{-1}$ para etanol ou ácido lático);

- A análise das velocidades médias de colonização mostrou que a combinação do inóculo de abatedouro de aves com ácido fórmico ou etanol promoveu os maiores resultados de velocidades médias $\left(0,012 \mathrm{~g} \mathrm{SVT} \mathrm{g}^{-1}\right.$ espuma dia ${ }^{-1}$ com ácido fórmico e $0,011 \mathrm{~g} \mathrm{SVT}^{-1}$ espuma dia ${ }^{-1}$ com etanol). 
Ensaios de remoção de sulfato em reatores $R A H L F$

- A relação $\mathrm{DQO} / \mathrm{SO}_{4}{ }^{2-}$ estequiométrica e de 1,92 não influenciou a remoção de sulfato quando aliada a drenagem ácida bruta e resultou em baixa remoção de DQO e sulfato nos sistemas estudados;

- A relação $\mathrm{DQO} / \mathrm{SO}_{4}{ }^{2-}$ influenciou o sistema de tratamento de drenagem ácida quando aliada a redução na carga de sulfato e resultou em maiores eficiências de remoção de sulfato $(72,8 \%)$ e de DQO $(75,7 \%)$

- O aumento no aporte de elétrons para uma relação $\mathrm{DQO} / \mathrm{SO}_{4}{ }^{2-}$ de 1,0 juntamente com a redução da carga de sulfato aplicada favoreceu ligeiramente os processos de remoção de sulfato $(74,5 \%)$

- A correção do pH afluente para 5,0 aliada a drenagem ácida bruta resultou em eficiências de remoção de DQO e sulfato de 37,8\% e 18,4\%, respectivamente, porém com a redução da carga de sulfato aplicada nesses sistemas, esses valores subiram para 65,0\% de remoção de DQO e 40,6\% de remoção de sulfato;

- A recirculação do efluente tratado afetou negativamente os processos de remoção de sulfato e DQO, com queda brusca nas eficiências e geração de acetato no efluente;

- A análise da diversidade microbiana mostrou que apenas nos reatores alimentados com drenagem bruta em algum momento da operação estavam presentes representantes do domínio Archaea.

- Nenhum clone do domínio Archaea encontrado pode ser relacionado a processos de redução de sulfato. 
- O filo Proteobacteria foi dominante no reator alimentado apenas com drenagem bruta e os clones foram alinhados com as espécies Acidithiobacillus ferrooxidans e Acidithiobacillus thiooxidans.

- Os reatores alimentados com drenagem diluída apresentaram predominância de representantes do filo Firmicutes e alinharam-se com linhagens de Clostridium sp., com a espécie Acidaminobacter hydrogenomorfans e com a espécie Fusibacter paucivorans, as três sugeridas como bactérias envolvidas em processos de redução de sulfato.

Ensaios de remoção de sulfato em reatores $U A S B$

- O aumento do volume da manta de lodo alimentado com drenagem bruta promoveu ligeira melhora na eficiência do reator quanto a remoção de sulfato (11,0\% para $156 \mathrm{ml}, 14,3 \%$ para $312 \mathrm{ml}$ e $24,4 \%$ para $468 \mathrm{ml})$.

- A redução na carga de sulfato afluente e a relação $\mathrm{DQO} / \mathrm{SO}_{4}{ }^{2-}$ estequiométrica resultou em eficiências de remoção de DQO de 51,4\% e de sulfato de $46,3 \%$. O aumento dessa relação para 1,0 promoveu aumento das eficiências para $67,4 \%$ de remoção de DQO e $85,6 \%$ de remoção de sulfato.

- A menor carga de sulfato aplicada direcionou o processo de oxidação da matéria orgânica para a via completa, resultando em pequeno acúmulo de acetato no efluente.

- A diluição do afluente promovida por uma corrente com água de abastecimento acoplada na entrada do reator afetou positivamente a remoção de DQO $(85,5 \%)$ e sulfato $(82,3 \%)$, sem alteração na via de oxidação da matéria orgânica. 
- A recirculação com efluente tratado promoveu um colapso no sistema, com queda acentuada na remoção de DQO e sulfato.

- Os perfis espaciais mostraram que o processo de remoção de sulfato ocorreu como em um reator de fluxo pistonado até cerca de $60 \%$ da altura do reator. 


\section{CAPÍTULO 7}

\section{SUGESTÕES}

A partir dos resultados obtidos na presente pesquisa, são propostas as seguintes sugestões para trabalhos futuros relacionados à remoção de sulfato de águas ácidas de minas:

- operar reatores UASB e RAHLF para drenagem ácida de minas com concentrações crescentes de sulfato e sem recirculação, visto que a recirculação do efluente tratado afetou negativamente o funcionamento dos reatores;

- operação do RAHLF e do reator UASB em escala piloto, em condições de reduzida carga de sulfato aplicada;

- avaliação do reator UASB para remoção de sulfato de DAM, porém com menor volume da lodo na manta, de forma que o reator pudesse operar com um comportamento típico de UASB;

- estudos mais específicos sobre a precipitação sulfetos metálicos resultantes da redução do sulfato e determinar a importância do $\mathrm{pH}$ efluente sobre o processo;

- avaliação de processos de recuperação de enxofre elementar a partir do sulfeto produzido nos reatores. 


\section{CAPÍTULO 8}

\section{REFERÊNCIAS}

Akcil, A., Koldas, S. (2006) Acid mine drainage (AMD): causes, treatment and case studies. Journal of Cleaner Production, v. 14, p. 1139-1145.

Arnaud, J.P-.; Lacroix, C.; Castaigne, F. (1992) Counterdiffusion of lactose and lactic acid in $\kappa$-carrageenan/locust bean gum gel beads with or without entrapped lactic acid bacteria. Enzyme Microbiology Technology, v. 14, p. 715-724.

Baker, B.J.; Banfield, J.F. (2003) Microbial communities in acid mine drainage. FEMS Microbiology, v. 44, p. 139-152.

Benedetto, J.S., Almeida, S.K., Gomes, H.A., Vazoller, R.F., Ladeira, A.C.Q. (2005) Monitoring of sulfate-reducing bacteria in acid water from uranium mines. Minerals Engineering, v. 18, p. 1341-1343.

Benner, S.G.; Blowes, D.W.; Cloud, W.D.; Herbert Jr., R.B.; Ptacek, C.J. (1999) Geochemistry of a permeable reactive barrier for metals and acid mine drainage. Environmental Science Technology, v. 33, p. 2793-2799.

Bonin, A.S.; Boone, D.R. (2006) The Prokaryotes: A Handbook on the Biology of Bacteria, v. 3, p. 231-243.

Cadillo-Quiroz, H.; Yashiro, E.; Yavitt, J.B.; Zinder, S.H. (2008) Characterization of the archaeal community in a minerotrophic fen and terminal restriction fragment length polymorphism-directed isolation of a novel hydrogenotrophic methanogen. Applied Environmental Microbiology, v. 74 (7), p. 2059-2068.

Caumette, P.; Cohen, Y.; Matheron, R. (1991) Isolation and characterization of Desulfovibrio halophilus sp. nov., a halophilic sulfate- reducing bacterium isolated from Solar Lake (Sinai). Systematic and Applied Microbiology, v. 14, p. 33-38.

Chan, O.C.; Yang, X.; Fu, Y.; Feng, Z.; Sha, L.; Casper, P.; Zou, X. (2006)16S rRNA gene analyses of bacterial community structures in the soils of evergreen broad-leaved forests in south-west China. FEMS Microbiology Ecology, v. 58(2), p. 247-259.

Clark, D.A.; Norris, P.R. (1996) Acidimicrobium ferrooxidans gen. nov., sp. nov.: mixedculture ferrous iron oxidation with Sulfobacillus species. Microbiology, v. 142, p. 785790.

Damianovic, M.H.R.Z., Foresti, E. (2007) Anaerobic degradation of synthetic wastewaters at different levels of sulfate and COD/sulfate ratios in horizontal-flow anaerobic reactors (HAIB). Environmental Engineering Science, v. 24(3), p. 371-381. 
Das, A.; Mishra, A.K.; Roy, P. (1992) Anaerobic growth on elemental sulfur using dissimilar iron reduction by autotrophic Thiobacillus ferrooxidans. FEMS Microbiology Letters, v. 97, p. 167-172.

De Smul, A.; Dries, J.; Goethals, L.; Grootaerd, H.; Verstraete, W. (1997) High rates of microbial sulphate reduction in a mesophilic ethanol-fed expanded-sludge-blanket reactor. Applied Microbiology and Biotechnology, v. 48, p. 297-303.

Diaz, E.E.; Stams, A.J.; Amils, R.; Sanz, J.L. (2006) Phenotypic properties and microbial diversity of methanogenic granules from a full-scale upflow anaerobic sludge bed reactor treating brewery wastewater. Applied Environmental Microbiology, v. 72(7), p. 49424949.

Dojka, M.A.; Hugenholtz, P.; Haack, S.K.; Pace, N.R. (1998) Microbial diversity in a hydrocarbon- and chlorinated-solvent-contaminated aquifer undergoing intrinsic bioremediation. Applied Environmental Microbiology, v. 64(10), p. 3869-3877.

Elliot, P.; Ragusa, S.; Catcheside, D. (1998) Growth of sulfate-reducing bacteria under acidic conditions in an upflow anaerobic bioreactor as a treatment system for acid mine drainage. Water Research, v. 32 (12), p. 3724-30.

Elshahed, M.S.; Youssef, N.H.; Spain, A.M.; Sheik, C.; Najar, F.Z.; Sukharnikov, L.O.; Roe, B.A.; Davis, J.P.; Schloss, P.D.; Bailey, V.L.; Krumholz, L.R. (2008) Novelty and uniqueness patterns of rare members of the soil biosphere. Applied Environmental Microbiology, v. 74 (17), p. 5422-5428.

Farias, C.E.G. Mineração e Meio Ambiente no Brasil. Relatório preparado para o CGEE, 2002.

Ficker, M.; Krastel, K.; Orlicky, S.; Edwards, E. (1999) Molecular characterization of a toluene-degrading methanogenic consortium. Applied Environmental Microbiology, v. 65(12), p. 5576-5585.

Garcia, C.; Moreno, D.A.; Ballester, A.; Blàzquez, M.L.; Gonzàlez, F. (2001) Bioremediation of an industrial acid mine water by metal-tolerant sulphate-reducing bacteria. Minerals Engineering, v. 14 (9), p. 997-1008.

Garcia, J.L.; Ollivier, B.; Whitman, W.B. (2006) The Prokaryotes: A Handbook on the Biology of Bacteria, v. 3, p. 208-230.

Garcia-Moyano, A.; Gonzalez-Toril, E.; Aguilera, A.; Amils, R. (2007) Prokaryotic community composition and ecology of floating macroscopic filaments from an extreme acidic environment, Rio Tinto (SW, Spain). Systematic and Applied Microbiology, v. 30(8), p. 601-614.

Garrity, G.; Boone, D.;Castenholz, R. (2001). Bergey's Manual of Systematic Bacteriology. Volume One: The Archaea and the Deeply Branching and Phototrophic Bacteria. 721p.

Godon, J.J.; Zumstein, E.; Dabert, P.; Habouzit, F.; Moletta, R. (1997) Molecular microbial diversity of an anaerobic digestor as determined by small-subunit rDNA sequence analysis. Applied Environmental Microbiology, v. 63(7), p. 2802-2813. 
Goebel, B.M.; Stackebrandt, E. (1994) Cultural and phylogenetic analysis of mixed microbial populations found in natural and commercial bioleaching environments. Applied Environmental Microbiology, v. 60(5), p. 1614-1621.

Grosskopf, R.; Janssen, P.H.; Liesack, W. (1998) Diversity and structure of the methanogenic community in anoxic rice paddy soil microcosms as examined by cultivation and direct 16S rRNA gene sequence retrieval. Applied Environmental Microbiology, v. 64(3), p. 960-969.

Hansen, T.A. (1994) Metabolism of sulpfate-reducing prokaryotes. Antonie van Leeuwenhoek, v. 66, p. 165-185.

Hao, O.J. (2000) Metal effects on sulfur cycle bacteria and metal removal by sulfate reducing bacteria. Environmental Technologies to Treat Sulfur Pollution: Principles and Engineering, IWA Publishing, London, p. 393-414.

Harada, H.; Vermura, S.; Momonoi, K. (1994) Interaction between sulphate reducing bacteria and methane producing bactéria in a UASB reactor fed with low strength wastes containing different levels of sulphate. Water Research, v. 28 (2), p. 355-367.

Hernandéz-Eugenio, G.; Fardeau, M-L.; Cayol, J-C.; Bharat, K.C.; Thomas, P.; Macarie, H.; Garcia, J-C.; Ollivier, B. (2002) Clostridium thiosulfatireducens sp. nov., a proteolytic, thiosulfate- and sulfur-reducing bacterium isolated from an upflow anaerobic sludge blanket (UASB) reactor. International Journal of Systematic and Evolutionary Microbiology, v. 52, p. 1461-1468.

Herrera, L., Hernández, J., Bravo, L.,Romo, L., Vera, L. (1997) Biological process for sulfate and metals abatement from mine effluents. Environmental Toxicology and Water Quality, v. 12, p. 101-107.

Heylen, K.; Vanparys, B.; Wittebolle, L.; Verstraete,W.; Boon, N.; De Vos,P. (2006) Cultivation of denitrifying bacteria: optimization of isolation conditions and diversity study. Applied Environmental Microbiology, v. 72(4), p. 2637-2643.

Hickey, R.F.; Wu, W.M.; Veiga, M.C.; Jones, R. (1991) Start-up operation, monitoring and control of high-rate anaerobic treatment systems. Water Science and Technology, v. 24, p. 207-255.

Hiraishi, A.; Kishimoto, N.; Kosako, Y.; Wakao, N.; Tano, T. (1995) Phylogenetic position of the menaquinone-containing acidophilic chemo-organotroph Acidobacterium capsulatum. FEMS Microbiology Letters, v. 132(1-2), p. 91-94.

Hirasawa, J.S.; Sarti, A.; Del Aguila, N.K.S.; Varesche, M.B.A. (2008) Application of molecular techniques to evaluate the methanogenic archaea and anaerobic bacteria in the presence of oxygen with different COD:Sulfate ratios in a UASB reactor. Anaerobe, v. 14, p. 209-218.

Hodges, C.F. (1992) Interaction of cyanobacteria and sulfate-reducing bacteria in subsurface black-layer formation in high-sand content golf greens. Soil Biology and Biochemistry, 24(10), p. 15-20. 
Hulshoff Pol, L.W.; Lens, P.N.L.; Weijma, J.; Stams, A.J.M. (2001) New developments in reactor and process technology for sulfate reduction. Water Science and Technology, v. 44, p. 67-76.

Jain, D.K. (1995) Evaluation of the semisolid Postgate's B medium for enumerating sulfatereducing bacteria. Journal of Microbiological Methods, v. 22,p. 27-38.

Jiménez-Rodríguez, A.M.; Durán-Barrantes, M.M.; Borja, R.; Sánchez, M.; Colmenarejo, M.F.; Raposo, F. (2009) Heavy metals removal from acid mine drainage water using biogenic hydrogen sulphide and effluente anaerobic treatment: Effect of pH. Journal of Hazardous Materials, v. 165, p. 759-765.

Johnson, D.B. (1995) Acidophilic microbial communities: candidates for bioremediation of acidic mine effluents. International Biodeterioration and Biodegradation, v. 35, p. 41-58.

Johnson, B.; Roberto, F.F. (1997) Heterotrophic acidophiles and their roles in the bioleaching of sulfide minerals. In: Rawlings DE (ed) Biomining: theory, microbes and industrial processes. Springer, Berlin Heidelberg New York, pp 259-279.

Jones, R.T.; McCormick, K.F.; Martin, A.P. (2008) Bacterial communities of Bartonellapositive fleas: diversity and community assembly patterns. Applied Environmental Microbiology, v. 74(5), p. 1667-1670.

Jong, T.; Parry, D.L. (2003) Removal of sulfate and heavy metals by sulfate reducing bacteria in short-term bench scale upflow anaerobic packed bed reactor runs. Water Research, v. 37(14) p. 3379-89.

Jorgensen, B.B.; Bak, F. (1991) Pathways and microbiology of thiosulfate transformations and sulfate reduction in a marine sediment (Kattegat, Denmark), Applied Environmental Microbiology, v. 57, p. 847-856.

Joseph, S.J.; Hugenholtz, P.; Sangwan, P.; Osborne, C.A.; Janssen, P.H. (2003) Laboratory cultivation of widespread and previously uncultured soil bacteria. Applied Environmental Microbiology, v. 69(12), p. 7210-7215.

Kaksonen, A.; Franzmann, P.; Puhakka, J. (2004) Effects of hydraulic retention time and sulfide toxicity on ethanol and acetate oxidation in sulfate-reducing metal-precipitating fluidized-bed reactor. Biotechnology and Bioengineering, v. 86(3), p. 322-343.

Kaksonen, A.H.; Puhakka, J.A. (2007) Sulfate reduction based process for the treatment of acid mine drainage and the recovery of metals. Engineering in Life Science, v. 7(6), p. 541-564.

Kamagata, Y.; Kawasaki, H.; Oyaizu, H.; Nakamura, K.; Mikami, E.; Endo, G.; Koga, Y.; Yamasato, K. (1992) Characterization of three thermophilic strains of Methanothrix ('Methanosaeta') thermophila sp. nov. and rejection of Methanothrix ('Methanosaeta') thermoacetophila. International Journal of Systematic Bacteriology, v. 42(3), p. 463-468.

Kelly, D.P.; Wood, A.P. (2000) Reclassification of some species of Thiobacillus to the newly genera Acidithiobacillus gen. nov., Halothiobacillus gen. nov., and Thermithiobacillus 
gen nov. International Journal of Systematic Evolutionary Microbiology, v. 50, p. 511516.

Kendall, M.M.; Boone, D.R. (2006) The Prokaryotes: A Handbook on the Biology of Bacteria, v. 3, p. 244-256.

Kolmert, A.; Johnson, D.B. (2001) Remediation of acidic waste waters using immobilized, acidophilic sulfate-reducing bacteria. Journal of Chemical Technology and Biotechnology, v. 76, p. 836-843.

Koster, I.W.; Rinzema, A.; De Vegt, A.L.; Lettinga, G. (1986) Sulphide inhibition of the methanogenic activity og granular sludge at various pH-levels. Water Research, v. 22 (102), p. 329-346.

Lane, D.J. (1991) 16S/23S rRNA sequencing. In: Stackebrandt E, Goodfellow M (eds) Nucleic acid techniques in bacterial systematics. John Wiley \& Sons, Chichester, p 115163.

Lane, D.J.; Harrison, A.P. Jr.; Stahl, D.; Pace, B.; Giovannoni, S.J.; Olsen, G.J.; Pace, N.R. (1992) Evolutionary relationships among sulfur- and iron-oxidizing eubacteria. Journal of Bacteriology, v. 174(1), p. 269-278.

Lens P.N.L.; Kuenen, J.G. (2001) The biological sulfur cycle: novel opportunities for environmental biotechnology. Water Science and Technology, v. 14 (8), p. 57-66.

Lens, P.N.L.; Visser, A.; Janssen, A.J.H. Hulshoff Pol, L.W.; Lettinga, G. (1998) Biotecnological treatment of sulfate-rich wastewaters. Critical Reviews in Environmental Science and Technology, v. 28 (1), p. 41-88.

Levenspiel, O. (2000) Engenharia das Reações Químicas. Editora Edgard Blucher Ltda.

Lima, A.C.F.; Silva, M.M.; Leite, S.G.F.; Gonçalves, M.M.M.; Granato, M. (1996) Anaerobic sulphate-reducing microbial process using UASB reactors for heavy metals decontamination. Clean Technology for the Mining Industry, University of Concepción, Concepción-Chile, p. 141-152.

Lomans, B.P.; Maas, R.; Luderer, R.; Op den Camp „H.J.; Pol, A.; van der Drift, C.; Vogels, G.D. (1999) Isolation and characterization of Methanomethylovorans hollandica gen. nov., sp. nov., isolated from freshwater sediment, a methylotrophic methanogen able to grow on dimethyl sulfide and methanethiol. Applied Environmental Microbiology, v. 65(8), p. 3641-3650.

Lovley, D. (2006) The Prokaryotes: A Handbook on the Biology of Bacteria, v. 2, p. 653-658.

Lovley, D.R.; Roden. E.E.; Phillips, E.J.P.; Woodward, J.C. (1993a) Enzymatic iron and uranium reduction by sulfate-reducing bacteria. Marine Geology, v. 113, p. 41-53.

Lovley, D.R.; Widman, P.K.; Woodward, J.C.; Phillips, E.J. (1993b) Reduction of uranium by cytochrome $c 3$ of Desulfovibrio vulgaris. Applied Environmental Microbiology, v. 59, p. 3572-3576. 
Ludwig, W.; Strunk, O.; Westram, R.; Richter, L.; Meier, H.; Yadhukumar, Buchner, A.; Lai, T.; Steppi, S.; Jobb, G.; Förster, W.; Brettske, I.; Gerber, S.; Ginhart, A.; Gross, O.; Grumann, S.; Hermann, S.; Jost, R.; König, A.; Liss, T.; Lüßmann, R.; May, M.; Nonhoff, B.; Reichel, B.; Strehlow, R.; Stamatakis, A.; Stuckmann, N.; Vilbig, A.; Lenke, M.; Ludwig, T.; Bode, A.; Schleifer, K-H. (2004) ARB: a software environment for sequence data. Nucleic Acids Research, v. 32(4), p. 1363-1371.

Luptakova, A., Kusnierova, M. (2005) Bioremediation of acid mine drainage contaminated by SRB. Hydrometallurgy, v. 77, p. 97-102.

Ma, F.; Wei, L.; Wang, L. Chang, C-C. (2008) Isolation and identification of the sulphatereducing bacteria strain $\mathrm{H} 1$ and its function for hydrolysed polyacrylamide degradation. International Journal of Biotechnology, v. 10(1), p. 55-63.

Macalady, J.L.; Jones, D.S.; Lyon, E.H. (2007) Extremely acidic, pendulous cave wall biofilms from the Frasassi cave system, Italy. Environmental Microbiology, v. 9(6), p. 1402-1414.

Mack, C.; Burgess, J.E.; Duncan, J.R. (2004) Membrane bioreactors for metal recovery from wastewaters: A review. Water SA, v. 30, p. 521-532.

Maillacheruvu, T.Y.; Parkin, G.F. (1996) Kinetics of growth, substrate utilization and sulfide toxicity for propionate, acetate, and hydrogen utilizers in anaerobic systems. Water Environment Research, v. 68( 7), p. 1099-1106.

Maree, J.P.; Strydom, W.F. (1985) Biological sulphate removal in an upflow packed bed reactor. Water Research, v. 19, p. 1101-1106.

Marquardt, D.W. (1963) An algorithm for least-squares estimation of nonlinear parameters. Journal of Society for Industrial and Applied Mathematics, v. 11, p. 431-441.

McCabe, W.L., Smith, J.C., Harriot, P. (1993) Unit Operations of Chemical Engineering. 5th edition. McGraw-Hill, USA.

McCauley, C.; O'Sullivan, A.; Weber, P.; Milke, M.; Trumm, D. (2009) Sulfate reduction and implications for metal removal in bioreactors from iron and aluminum dominated acid mine drainage. Water Research, v. 43(4), p. 961-970.

Melvin, A.N.W.T.; Hobson, P.P. (1994). Identification of anaerobic digester bacteria using polimerase chain reaction method. Bioresource Technology, v. 47, p. 73-80.

Messing, J. (1983) New M13 vectors for cloning. Methods in Enzymology, v.101, p. 20-78.

Mizuno, O.; Li, Y.Y.; Noike, T. (1994) Effects of sulfate concentration and sludge retention time on the interaction between methane production and sulfate reduction for butyrate. Water Science and Technology, v. 30 (8), p. 45-54.

Moraes, E.M.; Adorno, M.A.T.; Zaiat, M.; Foresti, E. (2000) Determinação de ácidos voláteis por cromatografia gasosa em efluentes de reatores anaeróbios tratando resíduos líquidos e sólidos. Anais da VI Oficina e Seminário Latino-Americano de Digestão Anaeróbia, Recife-Pernambuco, Brasil, v. 2, p. 235-238. 
Muyzer, G.; Stams, A.J.M. (2008) The ecology and biotechnology of sulphate-reducing bacteria. Nature Reviews Microbiology, v. 6, p. 441-454.

Nascimento, M.R.L. (1998) Remoção e recuperação de urânio de águas ácidas de mina por resina de troca iônica. Dissertação (Mestrado). Departamento de Química, Universidade Federal de São Carlos, São Carlos/SP.

Neculita, C.M.; Zagury, G. (2008) Biological treatment of highly contaminated acid mine drainage in batch reactors: Long-term and reactive mixture characterization. Journal of Hazardous Materials, v. 157, p. 358-366.

Nordwick, S. (2003) Development of SRB treatment systems for acid mine drainage. In: Proceedings of Hydrometallurgy 2003 - Fifth International Conference in Honor of Professor Ian Ritchie - V.2: Electrometallurgy and Environmental Hydrometallurgy, Edited by Young, A.M. et al. Vancouver, Canadá.

Norris, P.R.; Clark, D.A.; Owen, J.P.; Waterhouse, S. (1996) Characteristics of Sulfobacillus acidophilus sp. nov. and other moderately thermophilic mineral-sulphide-oxidizing bacteria. Microbiology, v. 142, p. 775-783.

Ohmura, N.; Sasaki, K.; Matsumoto, N.; Saiki, H. (2002) Anaerobic respiration using Fe ${ }^{3+}$, $\mathrm{S}^{0}$, and $\mathrm{H}_{2}$ in the chemolithoautotrophic bacterium Acidithiobacillus ferrooxidans. Journal of Bacteriology, v. 184, p. 2081-2087.

Ollivier, B.; Hatchikian, C.E.; Prensier, G.; Guezennec J.; Garcia, J.L .(1991)

Desulfohalobium retbaense gen. nov., sp. nov., a halophilic sulfate-reducing bacterium from sediments of a hypersaline lake in Senegal. International Journal of Systematic Bacteriology, v. 41, p. 74-81.

Omil, F.; Lens, O.; Hulshuff, P.; Lettinga, G. (1996) Effect of upward velocity and sulphide concentration on fatty acid degradation in a sulphidogenic granular sludge reactor.

Process Biochemistry, v. 31 (7), p. 699-710.

Perry, R.H.; Chilton, C.C. (1985) Chemical Engineers Handbook. 5 ed., McGraw-Hill, New York.

Pronk, J.T.; de Bruyn, J.C.; Bos, P.; Kuenen, J.G. (1992) Anaerobic growth of Thiobacillus ferrooxidans. Applied Environmental Microbiology, v. 58, p. 2227-2230.

Ravot, G.; Magot, M.; Fardeau, M.L.; Patel, B.K.; Thomas, P.; Garcia, J.L.; Ollivier, B. (1999) Fusibacter paucivorans gen. nov., sp. nov., an anaerobic, thiosulfate-reducing bacterium from an oil-producing well. International Journal of Systematic Bacteriology, v. 49, p. 1141-1147.

Resolução Conama. 2005. Número 357, 17 de março.

Ribeiro, R.; Varesche, M.B.A.; Foresti, E.; Zaiat, M. (2005) Influence of the carbon source on the anaerobic biomass adhesion on polyurethane foam matrices. Journal of Environmental Management, v. 74, p. 187-194. 
Rohwerder, T.; Gehrke, T.; Kinzler, K.; Sand, W. (2003) Bioleaching review part A: Progress in bioleaching: fundamentals and mechanisms of bacterial metal sulfide oxidation. Applied Microbiology and Biotechnology, v. 63, p. 239-248.

Sallam, A.; Steinbüchel, A. (2009) Clostridium sulfidigenes sp. nov., a mesophilic, proteolytic, thiosulfate- and sulfur-reducing bacterium isolated from pond sediment. International Journal of Systematic and Evolutionary Microbiology, v. 59(7), p. 16611665.

Sani,R.K.; Peyton, B.M.; Brown, L.T. (2001.) Copper-induced inhibition of growth of Desulfovibrio desulfuricans G20: assessment of its toxicity and correlation with those of zinc and lead. Applied Environmental Microbiology, v. 67(10), p. 4765-4772.

Sawyer, C.N.; McCarty, P.L.; Parkin, G.F. (2005) Chemistry for Environmental Engineering and Science. $752 \mathrm{p}$.

Schloss, P.D.; Handelsman, J. (2005) Introducing DOTUR, a computer program for defining operational taxonomic units and estimating species richness. Applied and Environmental Microbiology, v. 71(3), p. 1501-1506.

Sekiguchi, Y.; Kamagata, Y.; Syutsubo, K.; Ohashi, A.; Harada, H.; Nakamura, K. (1998) Phylogenetic diversity of mesophilic and thermophilic granular sludges determined by 16S rRNA gene analysis. Microbiology, v. 144, p. 2655-2665.

Selenska-Pobell, S. (2002) Diversity and activity of bacteria in uranium mining waste piles. In: Keith-Roach,M.J. and Lievens,F.R. (Eds.). Radioactivity in the Environmental, v. 22, p. 225-254.

Shayegan, J.; Ghavipanjeh, F.; Mirjafari, P. (2005) The effect of influet COD and upward flow velocity on the behaviour of sulphate-reducing bacteria. Process Biochemistry, v. 20, p. $2305-2310$.

Shrestha, P.M.; Noll, M.; Liesack,W. (2007) Phylogenetic identity, growth-response time and rRNA operon copy number of soil bacteria indicate different stages of community succession. Environmental Microbiology, v. 9(10), p. 2464-2474.

Silva, A.J.; Varesche, M.B.A.; Foresti, E.; Zaiat, M. (2002) Sulphate removal from industrial wastewater using a packed-bed anaerobic reactor. Process Biochemistry, v. 37, p. 927935.

Silva, A.J.; Hirasawa, J.S.; Varesche, M.B.A.; Foresti, E.; Zaiat, M. (2006) Evaluation of support materials for the immobilization of sulfate-reducing bacteria and methanogenic archaea. Anaerobe, v. 12, p. 93-98.

Somlev, V.; Banov, M. (1998) Three stage process for complex biotechnological treatment of industrial wastewater from uranium mining. Biotechnology Technology, v. 12, p. 637-639.

Song Y.C., Piak, B.C., Shin, H.S., La SJ. (1998) Influence of electron donor and toxic materials on the activity of sulfate-reducing bacteria for the treatment of electroplating wastewater. Water Science and Technology, v. 38, p. 187-194. 
Stams, A.J.M.; Hansen, T.A. (1984) Fermentation of glutamate and other compounds by Acidaminobacter hydrogenoformans gen. nov. sp. nov., an obligate anaerobe isolated from black mud. Studies with pure cultures and mixed cultures with sulfate-reducing and methanogenic bacteria. Archives of Microbiology, v. 137, p. 329-337.

Standard Methods for the Examination of Water and Wastewater (2005). 20th ed. American Public Health Association / American Water Works Association / Water Environment Federation, Washington, DC, USA.

Steed, V.S.; Suidan, M.T.; Gupta, M.; Miyahara, T.; Acheson, C.M.; Sayles, G.D. (2000) Development of a sulfate-reducing biological process to remove heavy metals from acid mine drainage. Water Environmental Research, v. 72, p. 530-535.

Stetter, K.O. (1988) Archaeoglobus julgidus gen. nov., sp. nov.: a new taxon of extremely thermophilic archaebacteria. Systematic Applied Microbiology, v. 10, p. 172-173.

Tamburini, E.; Leon, A.G.; Perito, B.; Mastromei, G. (2003) Characterization of bacterial pectinolytic strains involved in the water retting process. Environmental Microbiology, v. 5(9), p. 730-736.

Tang, K.; Baskaran, V.; Nemati, M. (2009) Bacteria of the sulfur cycle: An overview of microbiology, biokinetics and their role in petroleum and mining industries. Biochemical Engineering Journal, v. 44, p. 73-94.

Tsukamoto, T. K., Killion, H.A., Miller, G.C. (2004) Column experiments for microbial treatment of acid mine drainage: low-temperature, low-ph and matrix investigations. Water Research, v. 38, p. 1405-1418.

van Hille, R.P.; Boshoff, G.A.; Rose, P.D.; Duncan, J.R. (1999). A continuous process for the biological treatment of heavy metal contaminated acid mine water, Resource Conservation and Recycling, v. 27, p. 157-167.

Vasquez, M.; Espejo, R.T. (1997) Chemolithotrophic bacteria in copper ores leached at high sulfuric acid concentration. Applied Environmental Microbiology, v. 63(1), p. 332-334.

Veeken, A.H.M.; Rulkens, W.H. (2003) Innovative developments in the selective removal and reuse of heavy metals from wastewater. Water Science and Technology, v. 47, p. 916.

Visser, A.; Hulshoff Pol, L.W.; Lettinga, G. (1996) Competition of methanogenic and sulfidogenic bacteria. Water Science and Technology, v. 33 (3), p. 99-110.

Widdel, E. (1988) Microbiology and ecology of sulfate- and sulfurreducing bacteria. Biology of anaerobic microorganisms, John Wiley\& Sons, New York, p. 469-586.

White, C.; GAdd, G.M. (1996) Mixed sulphate-reducing bacterial cultures for bioprecipitation of toxic metals: factorial and response-surface analysis of the effects of dilution rate, sulphate and substrate concentration. Microbiology, v. 142, p. 2197-2205.

White, C.; Sayer, J.A.; Gadd, J.M. (1997) Microbial solubilization and immobilization of toxic metals: key biogeochemical process for treatment of contamination. FEMS Microbiology Review, v. 20, p. 503-516. 
Wolfe, R.F. (2006) The Prokaryotes: A Handbook on the Biology of Bacteria, v. 3, p. 3-9.

Yamaguchi, T.; Harda, H.; Hisano, T.; Yamazaki, S.; Tseng, I-C. (1999) Process behavior of UASB reactor treating a wastewater containing high strength sulfate. Water Research, v. 33(14), p. 3182-3190.

Yarzábal, A.; Brasseur, G.; Bonnefoy, V. (2002) Cytochromes c of Acidithiobacillus ferrooxidans. FEMS Microbiology Letters, v. 209, p. 189- 195.

Zaiat, M., Cabral, A.K.A., Foresti, E. (1994) Cell wash-out and external mass transfer resistance in horizontal-flow anaerobic immobilized sludge (HAIS) reactor. Revista Brasileira de Engenharia - Caderno de Engenharia Química, v. 11, p. 33-42.

Zaiat, M.; Rodrigues, J.A.D.; Foresti, E. (2000) External and internal mass transfer effects in na anaerobic fixed-bed reactor for wastewater treatment. Process Biochemistry, v. 35, p. 943-949. 